\title{
Natural Ah receptor agonists in the human diet : beneficial food components or unperceived risk factors?
}

\author{
Citation for published version (APA):
}

de Waard, W. J. (2008). Natural Ah receptor agonists in the human diet : beneficial food components or unperceived risk factors? [Doctoral Thesis, Maastricht University]. Universiteit Maastricht. https://doi.org/10.26481/dis.20081107ww

Document status and date:

Published: 01/01/2008

DOI:

10.26481/dis.20081107ww

Document Version:

Publisher's PDF, also known as Version of record

\section{Please check the document version of this publication:}

- A submitted manuscript is the version of the article upon submission and before peer-review. There can be important differences between the submitted version and the official published version of record.

People interested in the research are advised to contact the author for the final version of the publication, or visit the DOI to the publisher's website.

- The final author version and the galley proof are versions of the publication after peer review.

- The final published version features the final layout of the paper including the volume, issue and page numbers.

Link to publication

\footnotetext{
General rights rights.

- You may freely distribute the URL identifying the publication in the public portal. please follow below link for the End User Agreement:

www.umlib.nl/taverne-license

Take down policy

If you believe that this document breaches copyright please contact us at:

repository@maastrichtuniversity.nl

providing details and we will investigate your claim.
}

Copyright and moral rights for the publications made accessible in the public portal are retained by the authors and/or other copyright owners and it is a condition of accessing publications that users recognise and abide by the legal requirements associated with these

- Users may download and print one copy of any publication from the public portal for the purpose of private study or research.

- You may not further distribute the material or use it for any profit-making activity or commercial gain

If the publication is distributed under the terms of Article $25 \mathrm{fa}$ of the Dutch Copyright Act, indicated by the "Taverne" license above, 
Natural Ah receptor agonists in the human diet: beneficial food components or unperceived risk factors?

Pim de Waard 
The research described in this thesis was sponsored by The Centre for Human Nutrigenomics, The Netherlands (CHN).

The studies presented in this thesis were performed at the Nutrition and Toxicology Research Institute Maastricht (NUTRIM), RIKILT institute of Food Safety and the Division of Toxicology, Wageningen University, which all participate in the Graduate School VLAG (Food Technology, Agrobiotechnology, Nutrition and Health Sciences), accredited by the Royal Netherlands Academy of Arts and Sciences.

Cover: $\quad$ Pim de Waard

Print: Optima, Grafische Communicatie BV, Rotterdam

(C) Pim de Waard, 2008

ISBN: 978-90-8559-420-8 


\section{Natural Ah receptor agonists in the human diet: beneficial food components or unperceived risk factors?}

\section{Proefschrift}

ter verkrijging van de graad van doctor aan de Universiteit Maastricht, op gezag van de Rector Magnificus, Prof. mr. G.P.M.F. Mols, volgens het besluit van het College van Decanen, in het openbaar te verdedigen op vrijdag 7 november 2008 om 12:00 uur

door

\section{Wilhelm Johan de Waard}

geboren te Rhoon op 8 juni 1959

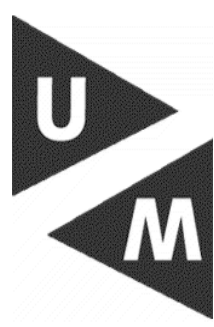


Promotor:

Co-promotores:

Beoordelingscommissie: Prof. dr. E.C.M. Mariman (voorzitter)

Prof. dr. A. Brouwer, Vrije Universiteit Amsterdam

Prof. dr. J.C.S. Kleinjans

Prof. dr. F.C.S. Ramaekers

Prof. dr. ir. I.M.C.M. Rietjens, Wageningen Universiteit 
Jch weisz es wofl, bejalyet utt noch Stutont, Bentooster scer! Shtch ciut gelelyrter Minut Stubiert so fort, weil er nicht antors faum. So baut mau sich ciu mü̈sæig Rartenlyatz,

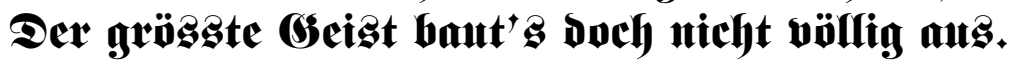

Mephistopheles in Goethe's Faust

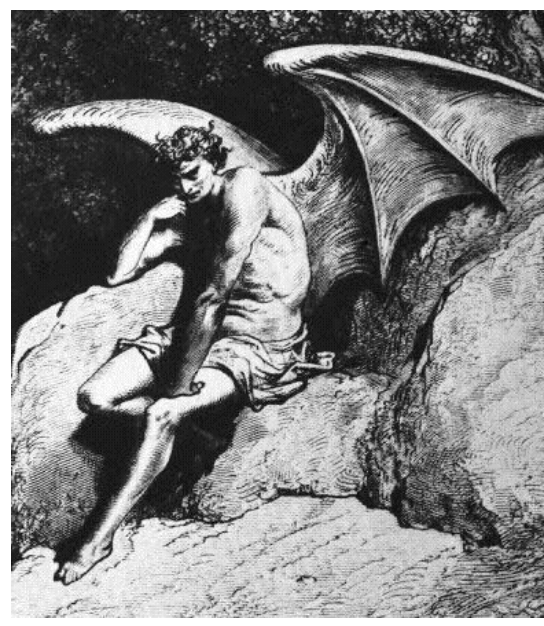





\section{Contents}

List of abbreviations $\quad 8$

$\begin{array}{lll}\text { Chapter } 1 & \text { General introduction } & 9\end{array}$

Chapter 2 Gene expression profiling in Caco-2 human colon cells exposed to TCDD, benzo[a]pyrene, and natural Ah receptor agonists from cruciferous vegetables and citrus fruits

Chapter 3 Ah receptor agonist activity in frequently consumed food items

Chapter 4 A human intervention study with foods containing natural Ah receptor agonists does not significantly show AhR-mediated effects as measured in blood cells and urine

Chapter 5 Repeated exposure of green fluorescent protein-based reporter cells (DRE-CAFLUX) improved detection of non-persistent aryl hydrocarbon (Ah) receptor agonists in low concentrations in human blood plasma

Chapter 6 Influence of TCDD and natural Ah receptor agonists on benzo[a]pyrene-

DNA adduct formation in the Caco-2 human colon cell line

Chapter $7 \quad$ Summary and general discussion

Een samenvatting voor de leek

Dankwoord

Curriculum Vitae

List of publications 


\section{LIST OF ABBREVIATIONS}

AhR

ARNT

$\mathrm{BaP}$

CPE

CYP

DMSO

DR CALUX

DRE-CAFLUX

EGFP

EROD

GJE

GST

I3C

ICZ

NAhRA

NER

NQO

TCDD

UDPGT
Aryl hydrocarbon receptor

Aryl hydrocarbon nuclear translocator

Benzo $[a]$ pyrene

Citrus pulp extract

Cytochrome p450

Dimethyl sulfoxide

Dioxin Receptor Chemically-Activated LUciferase eXpression

Dioxin Responsive Element-driven Chemical Activated FLUorescent

protein eXpression

Enhanced green-fluorescent protein

Ethoxyresorufin-O-deethylase

Grapefruit juice extract

Glutathione-S-transferase

Indole-3-carbinol

Indolo[3,2-b]carbazole

Natural AhR agonist

Nucleotide excision repair

Quinone oxidoreductase

2,3,7,8-tetrachlorodibenzo- $p$-dioxin

Uridine diphosphate glucuronosyl transferase 
General introduction 



\section{FOOD, HEALTH AND TOXICOLOGY}

The human diet is mainly based on food items containing carbohydrates, proteins and fat of animal or plant origin for acquiring energy and growth. Besides these macronutrients, food contains a large amount of micronutrients and other compounds of different nature, which notwithstanding its relative small part in weight can have a great impact on health. Animal products can contain e.g. minerals, hormones and vitamins, and vegetables and fruits contain besides the micronutrients many secondary metabolites like tannins, alkaloids, glucosinolates, polyphenols, coumarins and terpenes. This diverse group of phytochemicals causes the coloration, flavoring and odorization of the plant parts, and can achieve attractive or repellant effects on organisms. For humans, many phytochemicals can show both healthy and toxic effects, and many are used as medicines and poisons (Renwick et al., 2004; Rietjens et al., 2005). Since the complex nature of foods and the varying influences on human health, there is a growing interest in optimizing the human diet for health purposes in the form of food supplements, functional foods and nutraceuticals (Bagchi, 2006). However, not always is the mechanism of action of these bioactivating food ingredients elucidated, and many of them can show both toxic and healthy effects depending on the circumstances. Thus understanding toxicology plays an important role in determining when an enrichment of a food component in the human diet will be safe (Verschoyle et al., 2007). In this thesis, a group of food chemicals of natural origin has been investigated which is considered as benificial for human health, but at the same time shows a bio-activity that can be related to the toxic mechanism of well-known environmental pollutants like dioxins and polychlorinated biphenyls (PCBs), namely activation of the aryl hydrocarbon receptor (AhR).

\section{THE ARYL HYDROCARBON RECEPTOR}

The aryl hydrocarbon receptor (AhR) was originally identified and characterized due to its central role in the cellular response to many planar aromatic hydrocarbons. This receptor is a cytosolic receptor protein of the bHLH-PAS (basic-helix-loop-helix/Period-Aryl hydrocarbon receptor nuclear translocator-Single minded) family of heterodimeric transcriptional regulators. Its well conserved gene is expressed in most cell types of mammals, birds, fish, and invertebrates. The AhR is a transcriptional regulator and it is suggested that it plays physiological roles in cell proliferation and differentiation, in liver and immune system homeostasis and in tumor development, however, the endogenous ligand(s) and the functional role of the receptor activation are still largely unknown (Hankinson, 1995; Hahn, 2002; Barouki et al., 2007). The AhR received much attention for its role in the toxicity of the dioxins, a well-known group of environmental pollutants of which TCDD (2,3,7,8-tetrachlorodibenzo- $p$-dioxin) is the strongest agonist and activator in the picomolar concentration range. Many different species of laboratory animals showed a wide range of toxicological responses upon exposure to TCDD, e.g. tumor promotion, carcinogenesis, endocrine disruption, immunotoxicity and teratogenicity, which are related to activation of the AhR (Fernandez-Salguero et al., 1996; Mimura and Fujii-Kuriyama, 2003; Steenland et al., 2004). However, a large difference in susceptibility between species is observed (Safe, 2001; Bock and Kohle, 2006). As for humans, it 
is known that after accidental exposure to relatively high concentrations of TCDD, like during the disaster in Seveso, Italy 1977, chloracne is evidently proven, and tumor promotion of certain cancer types is highly probable, because of an increased cancer incidence and mortality at all cancer sites after dioxine exposures rather than at a specific site (Steenland et al., 2004; Landi et al., 2005).

Figure 1 shows a simplified diagram of the activation mechanism of the AhR. In the cytosol, the AhR is bound to two heat shock proteins (hsp90), and the proteins XAP2 (X-associated protein 2) and p23 (23-kDA co-chaperone protein). When a ligand, e.g. TCDD, enters the cell, it binds to the AhR and the protein complex moves to the nucleus of the cell. After entering the nucleus, the chaperon proteins detach and the AhR-ligand complex binds to the aryl hydrocarbon nuclear translocator protein (ARNT). Together, they bind to the DNA at dioxin responding elements (DRE) located in the promoter region of many AhR responding genes, e.g. the phase I biotransformation

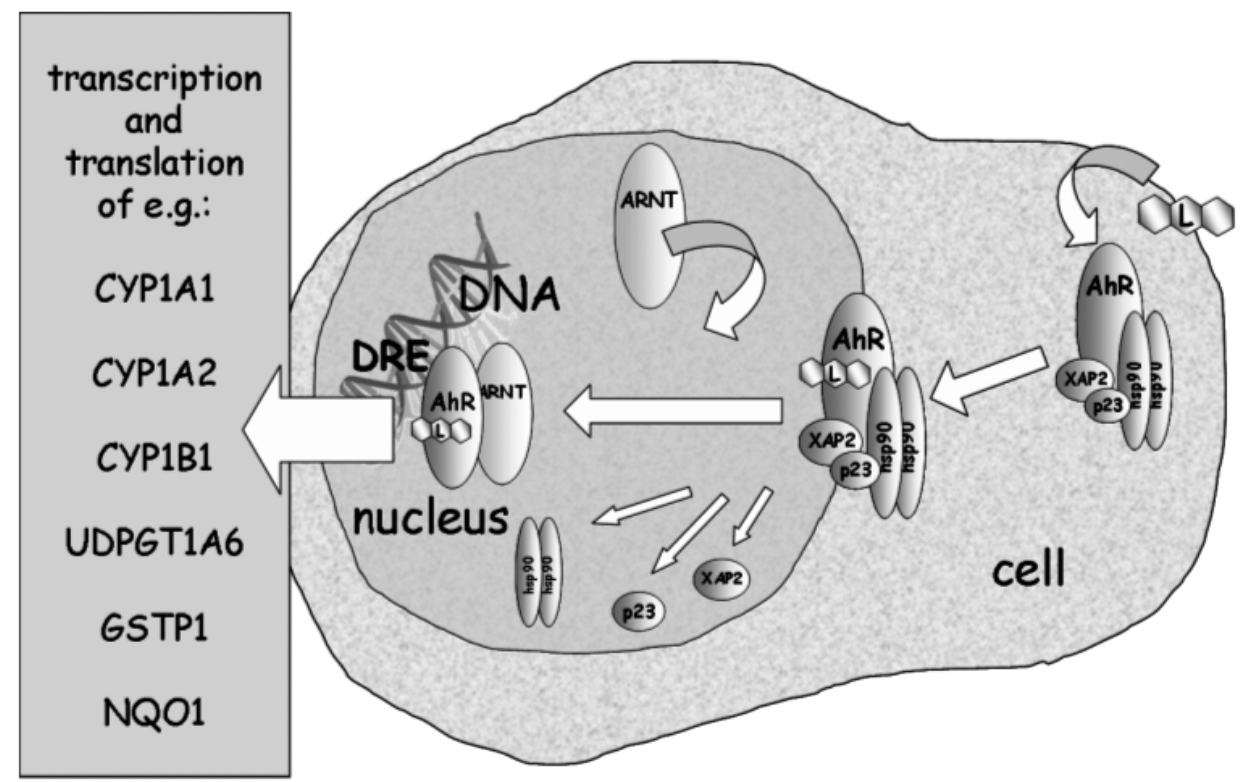

Fig. 1. Schematic presentation of the AhR activation. See the text for an explanation.

$\mathrm{L}$

AhR

hsp90

p23

XAP2

ARNT

DRE

CYP

UDPGT

GST

NQO
Ligand

Aryl hydrocarbon receptor

Heat shock protein 90

23-kDA co-chaperone protein

$\mathrm{X}$-associated protein 2

Aryl hydrocarbon nuclear translocator

Dioxin responsive element

Cytochrome p450

Uridine diphosphate glucuronosyl transferase

Glutathione-S-transferase

Quinone oxidoreductase 
P450 cytochromes CYP1A1, CYP1A2 and CYP1B1, and the phase II biotransformation enzymes glutathione-S-transferase P1 (GSTP1), uridine diphosphate glucuronosyl transferase 1A6 (UGT1A6) and $\mathrm{NAD}(\mathrm{P}) \mathrm{H}$ quinone oxidoreductase 1 (NQO1) (Hankinson, 1995; Denison et al., 2002; Barouki et al., 2007). These induced enzymes may play an important role in the detoxification of xenobiotic compounds like polycyclic aromatic hydrocarbons (PAHs), which are also agonists of the AhR, and may therefore stimulate their own metabolic conversion (Baird et al., 2005). TCDD is metabolized very slow in the human body and accumulates in fatty tissues, which is thought to be the main reason for its toxic potency (Bock and Kohle, 2006). The estimated half-life of TCDD in rats is 21 days (Pohjanvirta et al., 1990), and in humans even 6-7 years (Maruyama and Aoki, 2006). In some animal models, TCDD has particularly toxic potency in the developing embryo, causing structural malformations such as hydronephrosis and cleft palate (Couture et al., 1990). The more sustained or prolonged AhR activation by TCDD probably caused the observed cleft palate in mice, while the suspected endogenous potent AhR ligand ITE (2-(1'H-indole-3'-carbonyl)-thiazole-4-carboxylic acid methyl ester, isolated from porcine lung tissue) did not show this effect (Henry et al., 2006).

Low amounts of dioxin-like compounds in food or environmental samples can be measured by gas chromatography techniques with mass spectrometry detection (GC-MS), but for high throughput screening of AhR agonist activity in samples, the DR-CALUX' (Dioxin Receptor ChemicallyActivated LUciferase eXpression) reporter gene bioassay has been developed. Rat hepatoma H4IIE cells have been stably transfected with the reporter vector pGudLuc1.1 containing a dioxinresponsive element-driven firefly luciferase gene. The induction of luciferase by AhR-agonists can be detected by addition of luciferin and measurement of the resulting bioluminescence (Aarts et al., 1995; Garrison et al., 1996). The amount of persistent dioxin-like AhR agonists is expressed as TEQs (toxic equivalents), which is the concentration of a dioxin-like congener multiplied by its toxic equivalency factor (TEF) to relate its toxicity to that of TCDD (Van den Berg et al., 1998). The tolerable daily intake of dioxin-like compounds has been established by the WHO at $2 \mathrm{pg}$ TEQ/kg/ day or $140 \mathrm{pg}$ TEQ/day for a person of $70 \mathrm{~kg}$ (JECFA, 2002). Similarly the EC Scientific Committee for Food set the tolerable weekly intake to $14 \mathrm{pg}$ TEQ/kg/week, taking into consideration the accumulating effect (SCF, 2001).

\section{Natural AhR agonists}

In 1971 Wattenberg discovered that laboratory rats showed an increase in AhR activity (by then called induction of benzo[a]pyrene hydroxylase or arylhydrocarbon hydroxylase) after feeding with cruciferous vegetables (Wattenberg, 1971). Analysis of the food ingredients revealed that the compounds which were responsible for the AhR activation were indoles, especially indole-3carbinol (I3C) (Loub et al., 1975). These are metabolites from one of the omnipresent cruciferous glucosinolates, namely glucobrassicin. This secondary plant metabolite is rapidly transformed into I3C, glucose, isothiocyanate and sulphate by the enzyme myrosinase. This enzyme is stored in separate compartments of the plant cells and is released after crushing of the plant tissue, implying that $\mathrm{I} 3 \mathrm{C}$ 
is also formed after consumption of glucosinolate containing vegetables (Virtanen, 1967; Broadbent and Broadbent, 1998a). I3C undergoes self-condensation reactions in the acid environment of the stomach and forms a number of dimers, trimers and other types of heterocyclic aromates (Fig. 2). Whereas I3C is not a strong AhR activator by itself, one of the acid reaction products, indolo[3,2- $b]$ carbazole (ICZ) is a potent AhR activating compound. However, it is only formed in very low amounts (ca $8 \mathrm{ng} / \mathrm{mg} \mathrm{I3C).} \mathrm{It} \mathrm{is} \mathrm{still} \mathrm{unclear} \mathrm{which} \mathrm{compounds} \mathrm{of} \mathrm{the} \mathrm{acid} \mathrm{reaction} \mathrm{mixture} \mathrm{are} \mathrm{the}$ most important in the AhR activation (Bjeldanes et al., 1991; De Kruif et al., 1991; Rogan, 2006). Nowadays, many different natural AhR agonists (NAhRAs) and sources of NAhRAs have been found, e.g. the tryptophan photoproduct 6-formylindolo[3,2-b]carbazole (Wei et al., 1998),

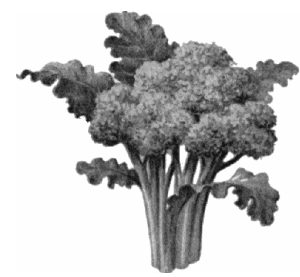

Cruciferous vegetables

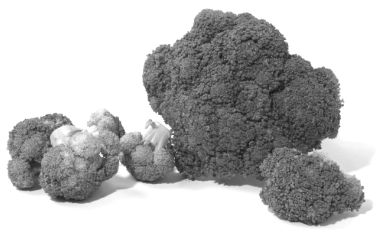

Preparation/consumption

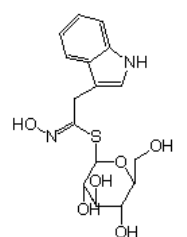

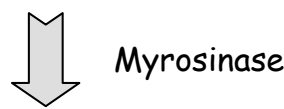<smiles>OCc1c[nH]c2ccccc12</smiles><smiles>[O-]c1ccccc1</smiles>

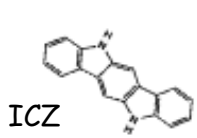<smiles></smiles>

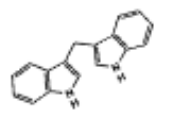

DIM

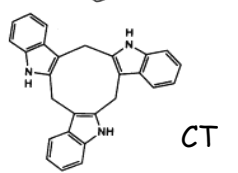

\section{Glucobrassicin}

Indole-3-carbinol

\section{Acid reaction products}

Fig. 2. The metabolism of glucobrassicin into bioactive acid reaction products. Of the many acid reaction products formed in the stomach, only the four most important ones are shown. ICZ, indolo[3,2-b]carbazole; LT, linear trimer; CT, cyclic trimer; DIM, diindolyl methane. 
Table 1. Some AhR-activating compounds identified in the human diet (Denison and Nagy, 2003; van Ede et al., 2008).

\begin{tabular}{ll}
\hline Compound & Origin \\
\hline 7,8-Dihydrorutacarpine & Citrus fruits \\
Carotinoids (canthaxanthin, astaxanthin, $\beta$-apo-8'carotenal) & Many plants, mushrooms, algae \\
Curcumin & Curry spice \\
Dibenzoylmethanes & Licorice \\
Flavonoids (quercetin, diosmin, tangeretin, tamarixetin) & Many vegetables and fruits \\
Furocoumarins (bergamottin, bergapten) & Citrus fruits \\
Indole-3-carbinol & Cruciferous vegetables \\
\hline
\end{tabular}

indirubin from natural dye compounds (Adachi et al., 2001), furocoumarins, like bergamottin, and polymethoxyflavones, like tangeretin, from citrus fruits (Canivenc-Lavier et al., 1996; Baumgart et al., 2005) and extracts of many fruits, vegetables and herbals from the human diet, suggesting a high exposure of humans (Amakura et al., 2003a; Jeuken et al., 2003; van Ede et al., 2008). A number of AhR-activating compounds in these food items have been identified (Table 1). Still, ICZ is one of the strongest AhR binding and activating NAhRAs (Denison and Nagy, 2003).

\section{TOXIC VERSUS BENEFICIAL EFFECTS OF AHR AgONISTS}

During the early days of NAhRA discovery, the induction of CYP1A1 by the activation of the AhR, was thought to be the main cause of the healthy, anti-cancer properties of cruciferous vegetables (Wattenberg, 1971). The induction of biotransformation enzymes, also called detoxification enzymes, was thought to be a first step in eliminating toxic compounds quickly from the cell. However, the CYP1A1 induction is also related to the cancer formation process caused by PAHs, of which benzo[a]pyrene $(\mathrm{BaP})$ is a well-known example. $\mathrm{BaP}$ itself is not a potent toxic compound, but biotransformation enzymes like CYP1A1 convert it into reactive electrophilic metabolites as e.g. benzo[a]pyrene-7,8-diol-9,10-epoxide (BPDE), which can easily bind to the DNA to form DNA adducts that may cause mutations and ultimately may lead to cancer (Baird et al., 2005). Against these toxic effects several cellular defense mechanisms exist. Phase II enzymes like glutathione-Stransferase (GST) and uridine diphosphate glucuronosyl transferase (UDPGT) can transform the electrophilic compounds into products which can be eliminated rapidly from the cell. In addition, DNA repair enzymes, like the nucleotide excision repair (NER) system, remove the bulky BaP-DNA adducts from the DNA (Hanawalt et al., 2003; Baird et al., 2005). This dynamic balance of metabolic pathways (Fig. 3) may be influenced by AhR agonists, and may thus influence the carcinogenic risk, because these agonists induce both phase I and phase II biotransformation enzymes and may direct the balance into a beneficial way or into an opposite way.

TCDD is considered to be a carcinogen in view of its tumor promoting properties that have been established in many animal experiments (Steenland et al., 2004). Also I3C has been investigated for its modulation of cancer inducing processes, and many experiments in rat, mouse and trout showed a tumor suppressive effect in breast, liver or colon. However, a number of experiments 


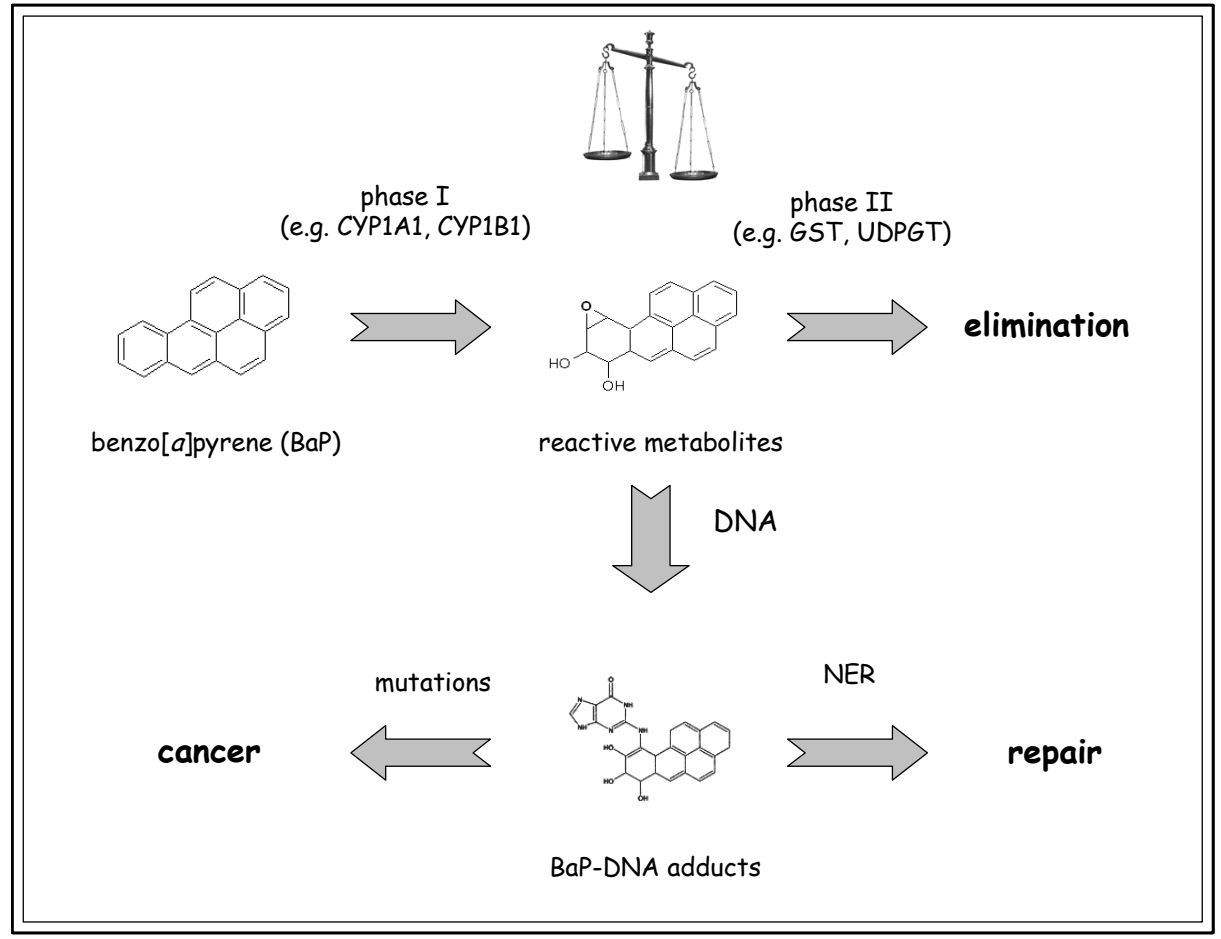

Fig. 3. The dynamic balance of possible metabolic routes of benzo[a]pyrene. CYP, cytochrome P450; GST, glutathione-S-transferase; UDPGT, uridine diphosphate glucuronosyl transferase; NER, nucleotide excision repair.

showed a tumor promotive or enhancing effect in liver or colon in these animal models, especially when I3C was given after the tumor initiating chemicals (Verhoeven et al., 1997; Broadbent and Broadbent, 1998b; Dashwood, 1998; Aggarwal and Ichikawa, 2005). This indicates that under certain circumstances the NAhRAs can induce similar tumor promotive mechanisms as xenobiotic AhR-agonists like TCDD. In view of the dualistic character of the role of the AhR, it is unfortunate that only a few studies compared the effects of I3C directly with TCDD. A number of in vitro and in vivo experiments show comparable effects of exposures to I3C or ICZ and TCDD, both toxic and beneficial. Both types of agonists show beneficial anti-estrogenic properties (Liu et al., 1994; Safe, 1995), inhibition of gap-junctional intercellular communication (GJIC), which is considered to play a role in tumor promotion (Herrmann et al., 2002), increased COX-2 expression leading to enhanced prostaglandin E2 production and colon cancer progression (Sherratt et al., 2003), increased oxidative DNA damage (Bjeldanes et al., 1991; Chen et al., 1995; Park et al., 1996; Pohjanvirta et al., 2002), and toxic reproductive effects in rats (Wilker et al., 1996). These observations emphasize the importance for more knowledge of the mechanisms that lies behind the effects of NAhRAs and that can be used for proper risk-benefit analyses. 
A complicating factor in the risk-benefit analysis of NAhRA consumption is that humans are usually exposed to these compounds in complex mixtures like foods (Denison and Nagy, 2003; Jeuken et al., 2003). Apart from NAhRAs, food products can also contain considerable amounts of AhR antagonists. Furthermore, some NAhRAs can show antagonistic effects on AhR activation by xenobiotic agonists, or inhibition of AhR induced enzymes (Amakura et al., 2003b). This raises the question to what extent these antagonists may influence the toxic effects of dioxin-like compounds.

\section{EPIDEMIOLOGY OF AHR AGONIST INDUCED HEALTH EFFECTS}

In contrast to the predominantly higher tumor incidence caused by dioxins found in epidemiological studies (Steenland et al., 2004), high intake of NAhRA containing foods show tumor suppressive effects in most epidemiological studies (Steinmetz and Potter, 1996; Verhoeven et al., 1996; Heber, 2004). However, a number of epidemiological studies on fruit and vegetable consumption does not show such a clear tumor suppression, and sometimes even tumor promotive effects are shown (Verhoeven et al., 1996; van Gils et al., 2005; Lynn et al., 2006).

It may be very difficult to identify the main cause of a tumor suppressive effect. For instance, according to the WCRF-report "Food, Nutrition, Physical Activity, and the Prevention of Cancer: a Global Perspective", cruciferous vegetables show a negative correlation with endometrial, oesophageal and oral cancer, but it is not clear whether this is caused by indoles or isothiocyanates, the other glucosinolate metabolites (WCRF/AICR, 2007). Isothiocyanates show a strong induction of phase II enzymes like GST and corresponding anti-oxidative effects by activating the electrophile-responsive element (Seow et al., 2002). Possibly, the combination of these food constituents is causing the protective effect. Besides, also harmful effects of consumption of cruciferous vegetables have been found. Figure 4 shows a number of cohort studies of consumption of cruciferous vegetables with both negative and positive effects on colon cancer (Lynn et al., 2006).

The modern trend to supply possible chemoprotective ingredients from fruit or vegetables in purified form and in sometimes extremely high concentrations as compared to normal dietary intake, makes it even more urgent to evaluate the health effects of NAhRA intake in epidemiological studies (Noonan and Noonan, 2006). For instance, the intake of $500 \mathrm{mg}$ I3C several times a day, instead of a few mg in a meal of broccoli or Brussels sprouts, and thus without the assumed beneficial effects of the isothiocyanates, theoretically could push the balance towards undesirable (toxic) side effects. A number of clinical trials have been carried out to examine the chemoprotective effects of I3C in women on breast and cervical cancer (Aggarwal and Ichikawa, 2005). One of the main findings was an increase of the estrogen metabolite ratio in urine of 2-hydroxyestrone to 16a-hydroxyestrone, which is a surrogate endpoint biomarker for reduced risk of breast cancer and caused by AhRdependent CYP1A1/1A2 activation (Bradlow et al., 1996; Aggarwal and Ichikawa, 2005). Together with an increase of the 2-/16a-hydroxyestrone ratio, reduced precancerous lesions of the cervix were found in women (Bell et al., 2000). No toxic or other side effects were found, but these studies are directed to breast and cervical cancer, and no conclusions can be drawn on the possible effects on the onset or outgrowth of other types of cancer (Aggarwal and Ichikawa, 2005). 


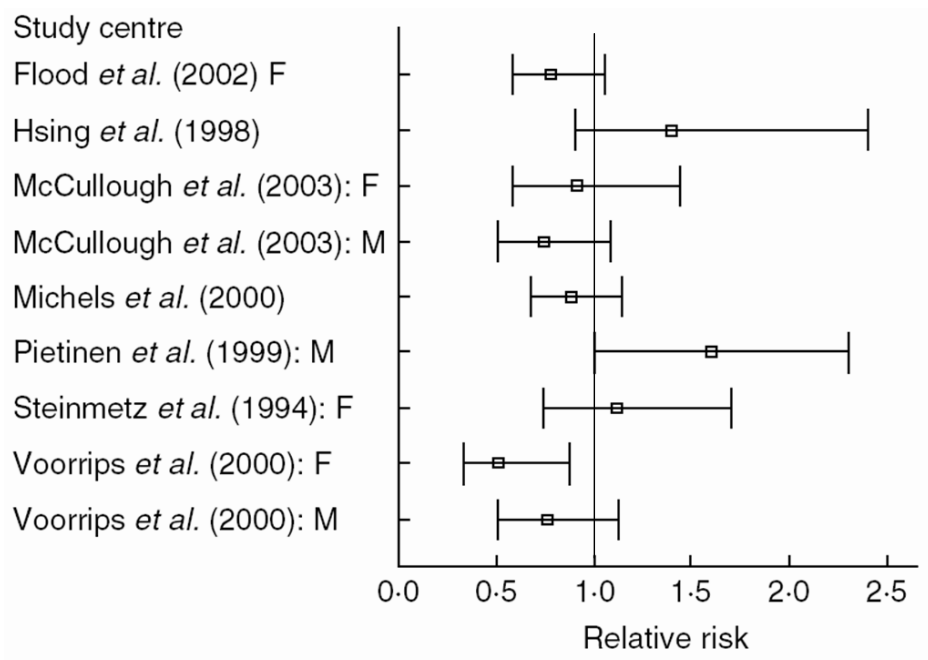

Fig. 4. Cohort studies of colon cancer and cruciferous vegetable consumption. Values are relative risks and $95 \%$ CI represented by horizontal bars. F, females; M, males (Lynn et al, 2006).

\section{TOXICOGENOMICS AND BIOMARKERS}

Despite more than 30 years of research on dioxin toxicity, the mechanistic pathways of TCDDtoxicity have not yet been revealed. The introduction of genomics tools in the field of toxicology offers new opportunities to study the possible toxic effects of NAhRAs. A relatively new tool for elucidating biological pathways involved in toxicological processes is the use of microarray technology (Aardema and MacGregor, 2002; Orphanides, 2003). With this technology, the expression of thousands of genes, called the transcriptome, can be determined simultaneously. After exposure of cells, tissues or laboratory animals, the mRNA is extracted from the cells of interest and transferred into fluorescent labeled cRNA or cDNA. Microarrays, which are chips or glass slides with thousands of different probes consisting of single strand cDNA molecules or oligonucleotides representing the genes, are exposed to the cRNA or cDNA samples. Each cRNA or cDNA hybridizes to its complementary sequence on the microarray and the fluorescent signal is measured. Difference in mRNA induction can be measured between exposed and control samples, and the resulting differential gene expression profiles can reveal certain affected biological pathways (Schena et al., 1995; Lockhart et al., 1996). RNA amplification techniques allow the use of very small amounts of RNA, in the order of nanomolars, to be extracted and purified. Figure 5 shows an example of such a procedure for a 22,000 spot oligonucleotide microarray of Agilent Technology, which we have used for gene expression profiling in this thesis. Shortly, the mRNA of extracted and purified RNA from e.g. exposed cells is converted into cDNA by use of reversed transferase (MMLV) and oligo dTpromotor primer. Subsequently, by addition of T7 RNA polymerase, NTPs and the dye Cy5-CTP to the cDNA, the cRNA is amplified and labeled. After purification, the cRNA can be hybridized to the microarray and the fluorescent dye signal can be measured with a fluorescence scanner. 
Usually, the expression of a small number of genes is also measured using the real-time reverse transcription polymerase chain reaction technique (RT-PCR) for confirmation of microarray studies. In this assay, the expressed mRNA from one or a few genes is reverse transcribed into cDNA, which is subsequently labeled and amplified in a cyclic way. The amount of fluorescent product is measured after each cycle and accurately quantified (Bustin, 2002).

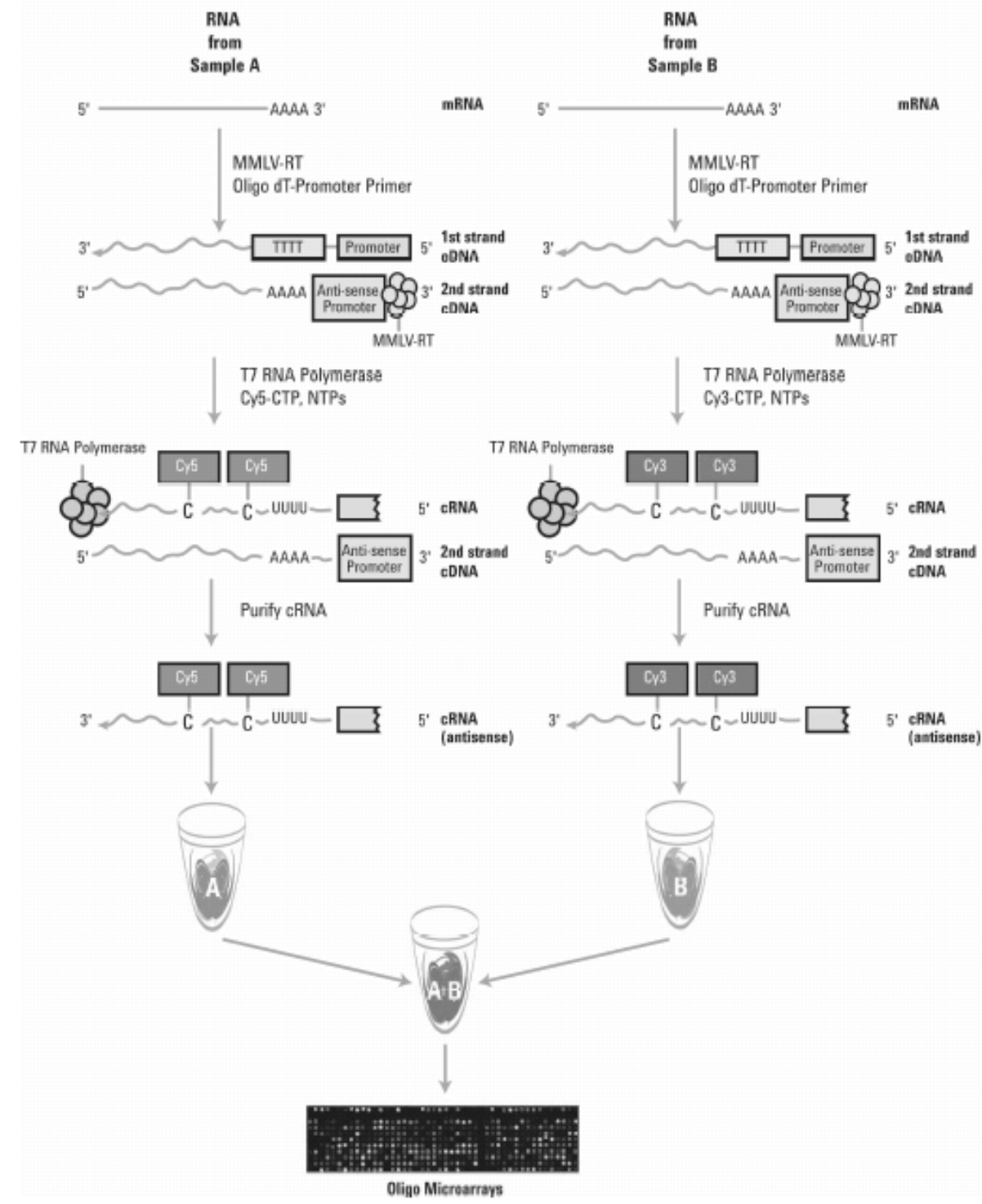

Fig. 5. Principle of the Agilent microarray fluorescent cRNA synthesis procedure (Agilent Technologies). Sample $A$ is the exposed specimen, sample B is the control or a reference. See text for further explanation. 
One of the main paradigms in toxicogenomics research is that certain profiles of gene expression can reveal mechanisms of toxicity and can be used as biomarkers for the involvement of specific toxicological pathways (Decristofaro and Daniels, 2008). In this way, the gene expression in cells exposed to NAhRAs can be compared to the expression profiles after exposure of the same type of cells to TCDD or other known AhR-agonists with a high toxic potential, like certain PAHs. This approach may elucidate weather or not the NAhRAs have similar effects at the transcriptome level as the toxic AhR-agonists or show significant different expression profiles, possibly indicating their beneficial potency. Shortly before the experiments started for this present thesis, a few microarray studies had been performed on human liver and airway epithelial cells after exposure to TCDD. Multiple genes were affected, especially concerning xenobiotic metabolism, cell cycle and cell proliferation. However, a clear understanding of the complicated molecular mechanisms governing the toxic effects of TCDD was not reached and a common biomarker for AhR-activation was not yet revealed (Puga et al., 2000; Frueh et al., 2001; Martinez et al., 2002).

\section{Aim AND OUTLine OF THE THESIS}

Based on the information presented above, it can be concluded that there is quite some uncertainty about potential hazardous and beneficial effects of NAhRAs in food and food supplements:

- $\quad$ There is convincing evidence that the toxic effects of dioxins and dioxin-like compounds are mediated by activation of the AhR pathway.

- $\quad$ Humans are frequently exposed to considerable amounts of NAhRAs in the diet.

- $\quad$ Some in vitro and in vivo experiments show dioxin-like toxicity of NAhRAs.

- $\quad$ Epidemiological studies of NAhRA-containing foods are neither conclusive about beneficial nor about harmful aspects of these types of foods.

The aim of this thesis is to investigate the similarities of NAhRAs with xenobiotic AhR agonists like $\mathrm{TCDD}$ and $\mathrm{BaP}$ at the level of gene expression and genotoxicity, and to determine if these effects of NAhRAs can be shown in humans. These insights may be helpful to understand the risks versus benefits that are related to intake of NAhRAs via the human diet. The emphasis will be put on those food categories which are thought to show beneficial health effects, like cruciferous vegetables and citrus fruits.

\section{The outline of the study is as follows:}

First, the effects on gene expression modulation in the human colon cancer cell line Caco-2 upon exposure to NAhRAs, $\mathrm{BaP}$ and TCDD is examined, in order to find similarities between these types of compounds at the transcriptomic level. As NAhRAs are chosen an extract of grapefruit juice, in the absence of a positive identification of the bioactive component, and ICZ, a representative pure component of the acid reaction mixture of I3C, originating from cruciferous vegetables. Typical 
AhR responsive sets of genes found in vitro will be used as biomarkers for AhR-agonist exposure in vivo (Chapter 2).

Secondly, an investigation of the presence and amounts of natural AhR agonists in common consumed food items in The Netherlands is performed. For this purpose, the extracts of a number of frequently consumed food items is examined for AhR-agonistic activity using the DR CALUX bioassay. The results are used to make an estimation of the daily exposure to NAhRAs in the human diet (Chapter 3).

Then, freshly isolated human lymphocytes are ex vivo exposed to xenobiotic AhR-agonists and NAhRAs to affirm the AhR-related gene expression profiles, found in the human Caco- 2 cell line, in an easily obtainable human tissue. A human intervention study is followed, in which volunteers are offered diets enriched in NAhRA-containing foods. Blood and urine samples are collected before and after the intervention to determine AhR-related effects on gene expression in blood cells and on activity of biotransformation enzymes (Chapter 4). Because AhR-related effects in blood are very small, the AhR-activity in plasma was analysed with two reporter gene bioassays: DR CALUX, a commonly used screening assay for dioxin-like compounds in foods and environmental samples, versus DRE CAFLUX (Dioxin Responsive Element-driven Chemical Activated FLUorescent protein eXpression), a relatively new comparable gene reporter assay, with a promising technique to potentiate very low AhR-activity signals (Chapter 5).

The (anti-)genotoxic effects of NAhRAs and TCDD are investigated by determining their influence on BaP-DNA adduct formation in Caco-2 cells. Both NAhRAs and TCDD induce phase I and II biotransformation enzymes like CYP1A1, CYP1B1 and NQO1, which can convert $\mathrm{BaP}$ into reactive DNA-binding metabolites, a mechanism to cause tumor formation, but can also remove potential toxic compounds quickly from the cell. Effects at the transcription level of a number of phase I and II enzymes, and some nucleotide excision repair genes are compared with effects on the toxic endpoint of BaP-DNA adduct formation (Chapter 6).

Finally, Chapter 7 contains a summary of the results and a general discussion. 


\section{REFERENCES}

Aardema, M. J., and MacGregor, J. T. (2002). Toxicology and genetic toxicology in the new era of "toxicogenomics": impact of “-omics" technologies. Mutat Res 499, 13-25.

Aarts, J. M., Denison, M. S., Cox, M. A., Schalk, M. A., Garrison, P. M., Tullis, K., de Haan, L. H., and Brouwer, A. (1995). Species-specific antagonism of Ah receptor action by 2,2'5,5'-tetrachloro- and 2,2'3,3'4,4'-hexachlorobiphenyl. Eur J Pharmacol 293, 463-474.

Adachi, J., Mori, Y., Matsui, S., Takigami, H., Fujino, J., Kitagawa, H., Miller, C. A., 3rd, Kato, T., Saeki, K., and Matsuda, T. (2001). Indirubin and indigo are potent aryl hydrocarbon receptor ligands present in human urine. J Biol Chem 276, 31475-31478.

Aggarwal, B. B., and Ichikawa, H. (2005). Molecular targets and anticancer potential of indole-3-carbinol and its derivatives. Cell Cycle 4, 1201-1215.

Amakura, Y., Tsutsumi, T., Nakamura, M., Kitagawa, H., Fujino, J., Sasaki, K., Toyoda, M., Yoshida, T., and Maitani, T. (2003a). Activation of the aryl hydrocarbon receptor by some vegetable constituents determined using in vitro reporter gene assay. Biol Pharm Bull 26, 532-539.

Amakura, Y., Tsutsumi, T., Sasaki, K., Yoshida, T., and Maitani, T. (2003b). Screening of the inhibitory effect of vegetable constituents on the aryl hydrocarbon receptor-mediated activity induced by 2,3,7,8-tetrachlorodibenzo-p-dioxin. Biol Pharm Bull 26, 1754-1760.

Bagchi, D. (2006). Nutraceuticals and functional foods regulations in the United States and around the world. Toxicology 221, 1-3.

Baird, W. M., Hooven, L. A., and Mahadevan, B. (2005). Carcinogenic polycyclic aromatic hydrocarbon-DNA adducts and mechanism of action. Environ Mol Mutagen 45, 106-114.

Barouki, R., Coumoul, X., and Fernandez-Salguero, P. M. (2007). The aryl hydrocarbon receptor, more than a xenobiotic-interacting protein. FEBS Lett.

Baumgart, A., Schmidt, M., Schmitz, H. J., and Schrenk, D. (2005). Natural furocoumarins as inducers and inhibitors of cytochrome P450 1A1 in rat hepatocytes. Biochem Pharmacol 69, 657-667.

Bell, M. C., Crowley-Nowick, P., Bradlow, H. I., Sepkovic, D. W., Schmidt-Grimminger, D., Howell, P., Mayeaux, E. J., Turbat-Herrera, E. A., and Mathis, J. M. (2000). Placebo-controlled trial of indole-3-carbinol in the treatment of CIN. Gynecol Oncol 78, 123-129.

Bjeldanes, L. F., Kim, J. Y., Grose, K. R., Bartholomew, J. C., and Bradfield, C. A. (1991). Aromatic hydrocarbon responsiveness-receptor agonists generated from indole-3-carbinol in vitro and in vivo: comparisons with 2,3,7,8-tetrachlorodibenzo-p-dioxin. Proc Natl Acad Sci U S A 88, 9543-9547.

Bock, K. W., and Kohle, C. (2006). Ah receptor: dioxin-mediated toxic responses as hints to deregulated physiologic functions. Biochem Pharmacol 72, 393-404.

Bradlow, H. L., Telang, N. T., Sepkovic, D. W., and Osborne, M. P. (1996). 2-hydroxyestrone: the 'good' estrogen. J Endocrinol 150 Suppl, S259-265.

Broadbent, T. A., and Broadbent, H. S. (1998a). 1 - 1. The chemistry and pharmacology of indole-3-carbinol (indole-3-methanol) and 3-(methoxymethyl)indole. [Part I]. Curr Med Chem 5, 337-352.

Broadbent, T. A., and Broadbent, H. S. (1998b). 1. The chemistry and pharmacology of indole-3-carbinol (indole3-methanol) and 3-(methoxymethyl)indole. [Part II]. Curr Med Chem 5, 469-491.

Bustin, S. A. (2002). Quantification of mRNA using real-time reverse transcription PCR (RT-PCR): trends and problems. J Mol Endocrinol 29, 23-39.

Canivenc-Lavier, M. C., Bentejac, M., Miller, M. L., Leclerc, J., Siess, M. H., Latruffe, N., and Suschetet, M. (1996). Differential effects of nonhydroxylated flavonoids as inducers of cytochrome P450 1A and 2B isozymes in rat liver. Toxicol Appl Pharmacol 136, 348-353.

Chen, Y. H., Riby, J., Srivastava, P., Bartholomew, J., Denison, M., and Bjeldanes, L. (1995). Regulation of CYP1A1 by indolo[3,2-b]carbazole in murine hepatoma cells. J Biol Chem 270, 22548-22555.

Couture, L. A., Abbott, B. D., and Birnbaum, L. S. (1990). A critical review of the developmental toxicity and teratogenicity of 2,3,7,8-tetrachlorodibenzo-p-dioxin: recent advances toward understanding the mechanism. Teratology 42, 619-627.

Dashwood, R. H. (1998). Indole-3-carbinol: anticarcinogen or tumor promoter in brassica vegetables? Chem Biol Interact 110, 1-5.

De Kruif, C. A., Marsman, J. W., Venekamp, J. C., Falke, H. E., Noordhoek, J., Blaauboer, B. J., and Wortelboer, H. M. (1991). Structure elucidation of acid reaction products of indole-3-carbinol: detection in vivo and enzyme induction in vitro. Chem Biol Interact 80, 303-315. 
Decristofaro, M. F., and Daniels, K. K. (2008). Toxicogenomics in biomarker discovery. Methods Mol Biol 460, 185-194.

Denison, M. S., and Nagy, S. R. (2003). Activation of the aryl hydrocarbon receptor by structurally diverse exogenous and endogenous chemicals. Annu Rev Pharmacol Toxicol 43, 309-334.

Denison, M. S., Pandini, A., Nagy, S. R., Baldwin, E. P., and Bonati, L. (2002). Ligand binding and activation of the Ah receptor. Chem Biol Interact 141, 3-24.

Fernandez-Salguero, P. M., Hilbert, D. M., Rudikoff, S., Ward, J. M., and Gonzalez, F. J. (1996). Aryl-hydrocarbon receptor-deficient mice are resistant to 2,3,7,8-tetrachlorodibenzo-p-dioxin-induced toxicity. Toxicol Appl Pharmacol 140, 173-179.

Frueh, F. W., Hayashibara, K. C., Brown, P. O., and Whitlock, J. P., Jr. (2001). Use of cDNA microarrays to analyze dioxin-induced changes in human liver gene expression. Toxicol Lett 122, 189-203.

Garrison, P. M., Tullis, K., Aarts, J. M. M. J. G., Brouwer, A., Giesy, J. P., and Denison, M. S. (1996). SpeciesSpecific Recombinant Cell Lines as Bioassay Systems for the Detection of 2,3,7,8-Tetrachlorodibenzo- $p$ dioxin-like Chemicals. Fund. Appl. Toxicol 30, 194-203.

Hahn, M. E. (2002). Aryl hydrocarbon receptors: diversity and evolution. Chem Biol Interact 141, 131-160.

Hanawalt, P. C., Ford, J. M., and Lloyd, D. R. (2003). Functional characterization of global genomic DNA repair and its implications for cancer. Mutat Res 544, 107-114.

Hankinson, O. (1995). The aryl hydrocarbon receptor complex. Annu Rev Pharmacol Toxicol 35, 307-340.

Heber, D. (2004). Vegetables, fruits and phytoestrogens in the prevention of diseases. J Postgrad Med 50, 145149.

Henry, E. C., Bemis, J. C., Henry, O., Kende, A. S., and Gasiewicz, T. A. (2006). A potential endogenous ligand for the aryl hydrocarbon receptor has potent agonist activity in vitro and in vivo. Arch Biochem Biophys 450, 67-77.

Herrmann, S., Seidelin, M., Bisgaard, H. C., and Vang, O. (2002). Indolo[3,2-b]carbazole inhibits gap junctional intercellular communication in rat primary hepatocytes and acts as a potential tumor promoter. Carcinogenesis 23, 1861-1868.

JECFA (2002). Polychlorinated dibenzodioxins, polychlorinated dibenzofurans, and coplanar polychlorinated biphenyls. In: Canady, R., Crump, K., Feeley, M., Freijer, J., Kogevinas, M., Malisch, R., Verger, P., Wilson, J., Zeilmaker, M. (Eds.), Safety Evaluation of Certain Food Additives and Contaminants. Report of the 57th Meeting of the Joint FAO/WHO Expert Committee on Food Additives and Contaminants. WHO Food Additives Series, vol. 48. World Health Organization, Geneva, pp. 451-664.

Jeuken, A., Keser, B. J. G., Khan, E., Brouwer, A., Koeman, J., and Denison, M. S. (2003). Activation of the Ah receptor by extracts of dietary herbal supplements, vegetables, and fruits. Journal of Agricultural and Food Chemistry 51, 5478-5487.

Landi, M. T., Bergen, A. W., Baccarelli, A., Patterson, D. G., Jr., Grassman, J., Ter-Minassian, M., Mocarelli, P., Caporaso, N., Masten, S. A., Pesatori, A. C., Pittman, G. S., and Bell, D. A. (2005). CYP1A1 and CYP1B1 genotypes, haplotypes, and TCDD-induced gene expression in subjects from Seveso, Italy. Toxicology 207, 191-202.

Liu, H., Wormke, M., Safe, S. H., and Bjeldanes, L. F. (1994). Indolo[3,2-b]carbazole: a dietary-derived factor that exhibits both antiestrogenic and estrogenic activity. J Natl Cancer Inst 86, 1758-1765.

Lockhart, D. J., Dong, H., Byrne, M. C., Follettie, M. T., Gallo, M. V., Chee, M. S., Mittmann, M., Wang, C., Kobayashi, M., Horton, H., and Brown, E. L. (1996). Expression monitoring by hybridization to highdensity oligonucleotide arrays. Nat Biotechnol 14, 1675-1680.

Loub, W. D., Wattenberg, L. W., and Davis, D. W. (1975). Aryl hydrocarbon hydroxylase induction in rat tissues by naturally occurring indoles of cruciferous plants. J Natl Cancer Inst 54, 985-988.

Lynn, A., Collins, A., Fuller, Z., Hillman, K., and Ratcliffe, B. (2006). Cruciferous vegetables and colo-rectal cancer. Proc Nutr Soc 65, 135-144.

Martinez, J. M., Afshari, C. A., Bushel, P. R., Masuda, A., Takahashi, T., and Walker, N. J. (2002). Differential toxicogenomic responses to 2,3,7,8-tetrachlorodibenzo-p-dioxin in malignant and nonmalignant human airway epithelial cells. Toxicol Sci 69, 409-423.

Maruyama, W., and Aoki, Y. (2006). Estimated cancer risk of dioxins to humans using a bioassay and physiologically based pharmacokinetic model. Toxicol Appl Pharmacol 214, 188-198.

Mimura, J., and Fujii-Kuriyama, Y. (2003). Functional role of AhR in the expression of toxic effects by TCDD. Biochimica Et Biophysica Acta-General Subjects 1619, 263-268. 
Noonan, C., and Noonan, P. W. (2006). Marketing dietary supplements in the United States: a review of the requirements for new dietary ingredients. Toxicology 221, 4-8.

Orphanides, G. (2003). Toxicogenomics: challenges and opportunities. Toxicol Lett 140-141, 145-148.

Park, J. Y., Shigenaga, M. K., and Ames, B. N. (1996). Induction of cytochrome P4501A1 by 2,3,7,8-tetrachlorodibenzo-p-dioxin or indolo(3,2-b)carbazole is associated with oxidative DNA damage. Proc Natl Acad Sci U S A 93, 2322-2327.

Pohjanvirta, R., Korkalainen, M., McGuire, J., Simanainen, U., Juvonen, R., Tuomisto, J. T., Unkila, M., Viluksela, M., Bergman, J., Poellinger, L., and Tuomisto, J. (2002). Comparison of acute toxicities of indolo[3,2-b] carbazole (ICZ) and 2,3,7,8-tetrachlorodibenzo-p-dioxin (TCDD) in TCDD-sensitive rats. Food Chem Toxicol 40, 1023-1032.

Pohjanvirta, R., Vartiainen, T., Uusi Rauva, A., Monkkonen, J., and Tuomisto, J. (1990). Tissue distribution, metabolism, and excretion of 14C-TCDD in a TCDD-susceptible and a TCDD-resistant rat strain. Pharmacol Toxicol 66, 93-100.

Puga, A., Maier, A., and Medvedovic, M. (2000). The transcriptional signature of dioxin in human hepatoma HepG2 cells. Biochem Pharmacol 60, 1129-1142.

Renwick, A. G., Flynn, A., Fletcher, R. J., Muller, D., J.G., Tuijtelaars, S., and Verhagen, H. (2004). Risk-benefit analysis of micronutrients. Food Chem Toxicol 42, 1903-1922.

Rietjens, I. M., Martena, M. J., Boersma, M. G., Spiegelenberg, W., and Alink, G. M. (2005). Molecular mechanisms of toxicity of important food-borne phytotoxins. Mol Nutr Food Res 49, 131-158.

Rogan, E. G. (2006). The natural chemopreventive compound indole-3-carbinol: state of the science. In Vivo 20, 221-228.

Safe, S. (2001). Molecular biology of the Ah receptor and its role in carcinogenesis. Toxicology Letters 120, 1-7.

Safe, S. H. (1995). Environmental and dietary estrogens and human health: is there a problem? Environ Health Perspect 103, 346-351.

SCF (2001). Opinion of the Scientific Committee on Food on the risk assessment of dioxins and dioxin-like PCBs in food. Scientific Committee on Food report CS/CNTM/DIOXIN/20 final', http://europa.eu.int/ comm/food/fs/sc/scf/out90_en.pdf.

Schena, M., Shalon, D., Davis, R. W., and Brown, P. O. (1995). Quantitative monitoring of gene expression patterns with a complementary DNA microarray. Science 270, 467-470.

Seow, A., Yuan, J. M., van den Berg, D., Lee, H. P., and Yu, M. C. (2002). Dietary isothiocyanates, glutathione S-transferase polymorphisms and colorectal cancer risk in the Singapore Chinese Health Study. Carcinogenesis 23, 2055-2061.

Sherratt, P. J., McLellan, L. I., and Hayes, J. D. (2003). Positive and negative regulation of prostaglandin E2 biosynthesis in human colorectal carcinoma cells by cancer chemopreventive agents. Biochem Pharmacol 66, 51-61.

Steenland, K., Bertazzi, P., Baccarelli, A., and Kogevinas, M. (2004). Dioxin revisited: developments since the 1997 IARC classification of dioxin as a human carcinogen. Environ Health Perspect 112, 1265-1268.

Steinmetz, K. A., and Potter, J. D. (1996). Vegetables, Fruit, and Cancer Prevention: A Review. Journal of the American Dietetic Association 96, 1027-1039.

Van den Berg, M., Birnbaum, L., Bosveld, A. T., Brunstrom, B., Cook, P., Feeley, M., Giesy, J. P., Hanberg, A., Hasegawa, R., Kennedy, S. W., Kubiak, T., Larsen, J. C., van Leeuwen, F. X., Liem, A. K., Nolt, C., Peterson, R. E., Poellinger, L., Safe, S., Schrenk, D., Tillitt, D., Tysklind, M., Younes, M., Waern, F., and Zacharewski, T. (1998). Toxic equivalency factors (TEFs) for PCBs, PCDDs, PCDFs for humans and wildlife. Environ Health Perspect 106, 775-792.

van Ede, K., Li, A., Antunes-Fernandes, E., Mulder, P., Peijnenburg, A. A., and Hoogenboom, L. A. (2008). Bioassay directed identification of natural Ah-receptor agonists in marmalade, submitted.

van Gils, C. H., Peeters, P. H., Bueno-de-Mesquita, H. B., Boshuizen, H. C., Lahmann, P. H., Clavel-Chapelon, F., Thiebaut, A., Kesse, E., Sieri, S., Palli, D., Tumino, R., Panico, S., Vineis, P., Gonzalez, C. A., Ardanaz, E., Sanchez, M. J., Amiano, P., Navarro, C., Quiros, J. R., Key, T. J., Allen, N., Khaw, K. T., Bingham, S. A., Psaltopoulou, T., Koliva, M., Trichopoulou, A., Nagel, G., Linseisen, J., Boeing, H., Berglund, G., Wirfalt, E., Hallmans, G., Lenner, P., Overvad, K., Tjonneland, A., Olsen, A., Lund, E., Engeset, D., Alsaker, E., Norat, T., Kaaks, R., Slimani, N., and Riboli, E. (2005). Consumption of vegetables and fruits and risk of breast cancer. Jama 293, 183-193.

Verhoeven, D. T., Goldbohm, R. A., van Poppel, G., Verhagen, H., and van den Brandt, P. A. (1996). Epidemiological studies on brassica vegetables and cancer risk. Cancer Epidemiol Biomarkers Prev 5, 733-748. 
Verhoeven, D. T. H., Verhagen, H., Goldbohm, R. A., van der Brandt, P. A., and van Poppel, G. (1997). A review of mechanisms underlying anticarcinogenicity by brassica vegetables. Chem Biol Interact 103, 79-129.

Verschoyle, R. D., Steward, W. P., and Gescher, A. J. (2007). Putative cancer chemopreventive agents of dietary origin: how safe are they? Nutr Cancer 59, 152-162.

Virtanen, A. I. (1967). Studies on organic sulphur compounds and other labile substances in plants. Bibl Nutr Dieta 9, 1-17.

Wattenberg, L. W. (1971). Studies of polycyclic hydrocarbon hydroxylases of the intestine possibly related to cancer. Effect of diet on benzpyrene hydroxylase activity. Cancer 28, 99-102.

WCRF/AICR (2007). Food, Nutrition, Physical Activity, and the Prevention of Cancer: a Global Perspective. AICR, Washington DC.

Wei, Y. D., Helleberg, H., Rannug, U., and Rannug, A. (1998). Rapid and transient induction of CYP1A1 gene expression in human cells by the tryptophan photoproduct 6-formylindolo[3,2-b]carbazole. Chem Biol Interact 110, 39-55.

Wilker, C., Johnson, L., and Safe, S. (1996). Effects of developmental exposure to indole-3-carbinol or 2,3,7,8-tetrachlorodibenzo-p-dioxin on reproductive potential of male rat offspring. Toxicol Appl Pharmacol 141, 68-75. 



\section{2}

Gene expression profiling in Caco-2 human colon cells exposed to TCDD, benzo[a]pyrene, and

\section{natural $\mathrm{Ah}$ receptor agonists from cruciferous vegetables and citrus fruits}

Pim W.J. de Waard a , Jac M.M.J.G. Aarts ${ }^{\text {b }}$, Ad A.C.M. Peijnenburg c, Hakan Baykus ${ }^{c}$, Elise Talsma ${ }^{c}$, Ans Punt ${ }^{b}$, Theo M.C.M. de Kok ${ }^{\text {a }}$, Frederik-Jan van Schooten ${ }^{a}$, Ron L.A.P. Hoogenboom ${ }^{c}$

a Department of Health Risk Analysis and Toxicology, Maastricht University, PO box 616, 6200 MD Maastricht, The Netherlands; b Division of Toxicology, Wageningen University, PO box 8000, 6700 EA Wageningen, The Netherlands, ' Toxicology \& Effect Monitoring Group, RIKILT Institute of Food Safety, PO box 230, 6700 EA Wageningen, The Netherlands 


\section{Abstract}

Cruciferous vegetables and citrus fruits are reported to possess health-beneficial properties, but also have been shown to contain natural aryl hydrocarbon receptor (AhR) agonists (NAhRAs). Binding to the AhR is widely assumed to activate the main pathway by which dioxins, like 2,3,7,8-tetrachlorodibenzo-p-dioxin (TCDD) exert their toxicity. To establish whether or not activation of the AhR pathway by NAhRAs and dioxin-like substances results in similar cellular responses, gene expression profiles induced in Caco- 2 cells were studied using microarray analysis. Cells were exposed to indolo[3,2-b]carbazole (ICZ), an acid reaction product from cruciferous vegetables, and to extracts of citrus pulp and grapefruit juice. Gene expression profiles induced by these NAhRAs were compared to those of the xenobiotic AhR agonists TCDD and benzo[a] pyrene $(\mathrm{B}[\mathrm{a}] \mathrm{P})$. Over 20 genes were found more than 1.5 times up- or downregulated by TCDD, and the expression of most of these genes was modulated in the same direction and to a similar extent by B[a]P and the NAhRAs. Results were confirmed by RT-PCR, and many of these genes may be involved in dioxin-related toxic effects. In conclusion, this in vitro study showed similar effects induced by NAhRAs, TCDD and B[a]P at the transcriptome level in a human intestinal cell line.
\end{abstract}




\section{INTRODUCTION}

The aryl hydrocarbon receptor $(\mathrm{AhR})$ is a transcription factor which is activated by ligand binding, and is expressed in most human tissue types. 2,3,7,8-Tetrachlorodibenzo-p-dioxin (TCDD) is the prototype AhR ligand and the most potent xenobiotic AhR agonist known. Upon ligand binding, the AhR-ligand complex is translocated into the nucleus of the cell and functions as a transcription factor binding to certain enhancer elements, called dioxin-responsive elements (DREs). This results in altered expression levels of AhR-responsive genes, among them the genes encoding for the biotransformation enzymes CYP1A1, CYP1A2, CYP1B1, UDPGT1A6, and GSTP1 (Hankinson, 1995; Denison and Nagy, 2003). Most if not all toxic effects of TCDD and other dioxin-like compounds are thought to be mediated by activation of AhR-regulated gene expression, e.g. chloracne, tumor promotion, immunosuppression and teratogenesis (Fernandez-Salguero et al., 1996; Mimura and Fujii-Kuriyama, 2003; Steenland et al., 2004).

Besides environmental contaminants like certain dioxins, polychlorinated biphenyls (PCBs) and polycyclic aromatic hydrocarbons (PAHs), also AhR agonists from plant and other biotic origins are known (Denison and Nagy, 2003). Cruciferous vegetables like Brussels sprouts, cabbage and broccoli contain e.g. AhR agonist precursors in the form of glucosinolates, which are converted via indole-3-carbinol (I3C) into I3C condensation products during food preparation, consumption and subsequent incubation in the acid environment of the stomach (Bjeldanes et al., 1991; Broadbent and Broadbent, 1998). Examples of these compounds are diindolylmethane (DIM) and indolo[3,2-b] carbazole (ICZ), of which the latter is a very potent AhR agonist (Kleman et al., 1994; Bergman et al., 2001). Also many other food items appear to contain high levels of AhR-activity, as judged by the DR CALUX* bioassay (Jeuken et al., 2003). Recently it was reported that hexane extracts of citrus products show strong AhR agonist activity (Hoogenboom, 2002). It is known that citrus fruits contain furocoumarins, like bergamottin, and polymethoxyflavones, like tangeretin, which were reported to be AhR agonists (Canivenc-Lavier et al., 1996; Baumgart et al., 2005).

Considering that both NAhRAs and persistent xenobiotic AhR agonists trigger the same gene regulatory pathway, it may be expected that the gene expression patterns induced by both groups of AhR agonists will be similar to a certain extent. Several studies describe AhR-mediated adverse effects of NAhRAs, especially for the I3C metabolite ICZ, such as inhibition of gap-junctional intercellular communication (GJIC), which is considered to play a role in tumor promotion (Herrmann et al., 2002), increased COX-2 expression leading to enhanced prostaglandin E2 production and colon cancer progression (Sherratt et al., 2003), and increased oxidative DNA damage (Bjeldanes et al., 1991; Chen et al., 1995; Park et al., 1996; Pohjanvirta et al., 2002). However, because NAhRAs were found to induce beneficial gene expression effects, such as phase II biotransformation and antioxidant enzyme induction (Chen and Yang, 2002), inhibition of phase I-mediated procarcinogen activation (Wen et al., 2002; Sarkar and Li, 2004), and antiestrogenic effects in human breast cancer cells (Liu et al., 1994), they are actually considered to be natural cancer-chemopreventive agents. Furthermore, in an in vivo study in TCDD-sensitive rats relatively high doses of ICZ did not produce any of the 
acute toxicity effects of TCDD, although moderate CYP1A1 induction in the liver was observed (Pohjanvirta et al., 2002).

It is generally assumed that the apparent discrepancy between the toxicity of TCDD and compounds like ICZ is caused by their great difference in persistence in biological systems (Chen et al., 1995; Pohjanvirta et al., 2002). Pohjanvirta et al. estimated that the elimination half-life of ICZ in rats is less than a day, possibly in the order of a few hours, whereas the half-life of TCDD in rats is estimated at 21 days (Pohjanvirta et al., 1990), and in humans even 6-7 years (Maruyama and Aoki, 2006). It cannot be excluded that the large difference in biostability between NAhRAs and persistent xenobiotic AhR agonists may result in differences between the gene sets modulated by both groups, and that selective AhR modulators as described by Safe et al (Safe et al., 1999) do exist within the large group of NAhRAs. None of these possible differences have been comprehensively studied thus far. This issue is even more relevant regarding the increasing popularity of dietary supplements with large amounts of pure I3C or DIM, especially if consumed on a regular basis (Zeligs, 2002). As a first step on examining this issue, the objective of the present study was to determine the gene expression profiles in the human intestinal epithelial cell-line Caco-2 after exposure to ICZ or extracts from citrus fruit products, and compare these with the profiles obtained after exposure to well known xenobiotic AhR agonists. These included the persistent dioxin TCDD as well as the readily biodegradable compound benzo $[a]$ pyrene $(\mathrm{B}[\mathrm{a}] \mathrm{P})$. The Caco- 2 cell line was chosen since it is generally used as a model system to study the effect and absorption of compounds in the small intestine. By using microarrays, the expression of thousands of genes can be examined simultaneously. The more the transcriptome profiles look alike, the more likely it is that the compounds under investigation may exert similar biologic, pharmacologic or toxic effects (Aardema and MacGregor, 2002). This may also lead to the identification of a set of gene expression biomarkers for TCDD- or NAhRA-like effects. This study will focus on effects on the transcriptome level, but follow-up studies with e.g. human volunteers will need to take into account other possibly important factors, such as proteomics, absorption and metabolism.

\section{MATERIALS AND METHODS}

\section{Preparation of extracts of citrus products}

Citrus pulp, used for animal feed, was originally imported from the USA, grapefruit juice (1 litre of juice is obtained from ca $2.5 \mathrm{~kg}$ of grapefruit) was bought at a local supermarket. Five gram of pulp or $10 \mathrm{ml}$ of juice were mixed with $20 \mathrm{ml}$ of methanol/water 85/15, and after $30 \mathrm{~min}$ extracted twice with $20 \mathrm{ml}$ of $\mathrm{n}$-hexane/diethyl ether $97 / 3$ following mixing for $1 \mathrm{~h}$. Hexane-layers were collected, evaporated and the residue dissolved in $40 \mu \mathrm{l}$ of DMSO (Merck, Darmstadt, Germany). Ten ml of water (Ultra Pure) was used for a blank extraction. Because the extracts contain a mixture of compounds, concentrations are expressed as gram extracted sample (pulp, juice or water) per litre medium used to expose the cells. 


\section{HPLC-analysis of extracts of citrus products}

Twenty $\mu \mathrm{l}$ of extract in DMSO was dissolved in $1 \mathrm{ml}$ of methanol, and $100 \mu \mathrm{l}$ was analyzed on an HPLC-system (Waters, Milford, USA) using an in-house developed method. In short, samples were eluted over a Supelco LC-18-DB column, $250 \mathrm{~mm}$ x $4.6 \mathrm{~mm} / 5 \mu \mathrm{m}$, gradual elution of $0.8 \mathrm{ml} / \mathrm{min}$. in methanol/water 10/90 -90/10 in $40 \mathrm{~min}$. UV-detection of analytes was performed by diode array (Waters) at $325 \mathrm{~nm}$. NAhRA components in the extracts were identified on the basis of co-elution with purified standards of the polymethoxy flavones sinensetin, tetramethylscutellarein, nobiletin, heptamethoxyflavone and tangeretin, and the furocoumarin bergamottin (all purchased from APIN Chemicals, Abingdon, UK), and in addition, by comparison of the UV-spectra. For concentration determination calibration curves of the standards were made.

\section{Cell cultures and exposures}

DR CALUX ${ }^{\circ}$ cells (rat H4IIE hepatoma cells stably transfected with pGudluc1.1, an AhR-regulated luciferase reporter plasmid) (Aarts et al., 1995) were grown in a-MEM (Sigma, St-Louis, USA), containing $10 \%$ fetal bovine serum (GIBCO, Breda, The Netherlands) and $1 \%$ penicillin/streptomycin (Sigma), at $37^{\circ} \mathrm{C}$ and $5 \% \mathrm{CO}_{2}$.

The Caco-2 human colorectal adenocarcinoma cell-line (ATCC, Manassas, USA) was grown in DMEM (Sigma), containing $10 \%$ fetal bovine serum and $1 \%$ penicillin/streptomycin, at $37^{\circ} \mathrm{C}$ and $5 \% \mathrm{CO}_{2}$.

Cells were seeded $24 \mathrm{~h}$ before exposure in 6-well plates (microarray assay, $5.10^{5}$ cells/well) or in 48 well-plates (DR CALUX ${ }^{\circ}$ and EROD assays, $5.10^{4}$ cells/well) and exposed for $24 \mathrm{~h}$ to sample solutions in DMSO added to the culture medium. Concentration ranges were made of 1-5000 pM TCDD (purity 98\%, Schmidt BV, Amsterdam, The Netherlands), 0.03-300 nM ICZ (purity $>95 \%$, synthesized as described by Bergman (Bergman, 1970) and checked for quality by HPLC, NMR, IR and MS, and with a reference sample (A kind gift of prof. J. Bergman, Department of Chemistry, Royal Institute of Technology, and Department of Biosciences at Novum, Huddinge, Sweden), 0.01-10000 nM benzo[a]pyrene (purity >98\%, Aldrich, Steinheim, Germany), 3-625 g/l citrus pulp extract, and 5-1250 g/l grapefruit juice extract for the DR CALUX and EROD assays. For the microarray analysis, cells were exposed to $0.5 \%$ DMSO, 500 pM TCDD, $1 \mu \mathrm{M}$ B[a]P, 100 nM ICZ, $208 \mathrm{~g} / \mathrm{l}$ citrus pulp extract, $417 \mathrm{~g} / \mathrm{l}$ grapefruit juice extract or $417 \mathrm{~g} / \mathrm{l}$ blank extract. These concentrations are based on a near maximum AhR activation to obtain a high as possible signal in the microarray experiments. The final concentration of DMSO in all exposures was $0.5 \%(\mathrm{~V} / \mathrm{V})$.

\section{DR CALUX assay}

The Dioxin Receptor - Chemical-Activated LUciferase gene eXpression assay was performed as described previously (Bovee et al., 1998). After exposure of the cells in 48-well microtiter plates the medium was removed and cells were washed with PBS. Cells were lysed using Cell Culture Lysis Reagent (Promega), centrifuged and $20 \mu$ of lysed solution of each well was transferred to a 96 wells plate. Luminescence was measured with a LuminoskanAscent (Thermo Labsystems, Finland) upon 
addition of $0.1 \mathrm{ml}$ of assay mixture $\left(20 \mathrm{mM}\right.$ Tricine, $1.07 \mathrm{mM}\left(\mathrm{MgCO}_{3}\right)_{4} \mathrm{Mg}(\mathrm{OH})_{2} \cdot 5 \mathrm{H}_{2} \mathrm{O}, 2.67 \mathrm{mM}$ $\mathrm{MgSO}_{4} \cdot 7 \mathrm{H}_{2} \mathrm{O}, 0.1 \mathrm{mM}$ EDTA, $33.3 \mathrm{mM}$ DTT, $261 \mu \mathrm{M}$ Coenzyme A, $470 \mu \mathrm{M}$ Luciferin, $530 \mu \mathrm{M}$ ATP, $\mathrm{pH}$ 7.8). By use of the program SlideWrite V6 and the formula $\mathrm{a} 0 /\left(1+(\mathrm{x} / \mathrm{a} 1)^{\wedge} \mathrm{a} 2\right)$, which describes the $\mathrm{AhR}$ activation process suitably, $\mathrm{EC}_{50}$ and maximal response values were calculated.

\section{EROD assay}

The ethoxyresorufin-O-deethylase assay was performed according to Burke and Mayer (Burke and Mayer, 1974) with modifications, as described below. After exposure of the Caco-2 cells in 48well microtiter plates the medium was removed and cells were washed twice with EMEM (Sigma, St-Louis, USA). A total of $150 \mu \mathrm{l}$ of $5 \mu \mathrm{M}$ ethoxyresorufin (Sigma) was added and the cells were incubated for $30 \mathrm{~min}$. Subsequently, $50 \mu \mathrm{l}$ of the solution was transferred into a 96 wells plate, $50 \mu \mathrm{l}$ of $2 \mathrm{mg} / \mathrm{ml}$ sulfatase (Sulfatase from Helix pomatia type $\mathrm{H}$ - 1 , sulfatase $>10,000 \mathrm{U} / \mathrm{g}, \beta$-glucuronidase $>300,000 \mathrm{U} / \mathrm{g}$, Sigma) in $0.2 \mathrm{M}$ sodium acetate ( $\mathrm{pH}$ 5) was added and incubated for one hour at $37^{\circ} \mathrm{C}$ and $5 \% \mathrm{CO}_{2}$. After incubation, $175 \mu \mathrm{l}$ of $0.15 \mathrm{M}$ Tris- $\mathrm{HCl} \mathrm{pH} 7.8$ was added and fluorescence was measured by a spectrophotometer (LS 50B, Perkin Elmer, excitation $510 \mathrm{~nm}$, emission $586 \mathrm{~nm}$ ).

\section{RNA isolation}

After exposure total RNA was isolated from the cells using Trizol (Invitrogen, Breda, The Netherlands) according to the manufacturer's protocol. Purity and integrity of the RNA were checked by gel electrophoresis and UV-absorption.

\section{cDNA microarray}

Microarray analysis was performed using an indirect labeling method as described previously (Pellis et al., 2003). Twenty $\mu \mathrm{g}$ of total RNA per sample was incubated with SuperScript II Rnase H reverse-transcriptase (Invitrogen) and aminoallyl-dUTP (Sigma) was incorporated and coupled to Cy5 monofunctional dye (Amersham Pharmacia Biotech Benelux, Roosendaal, The Netherlands). Universal Human Reference RNA (Stratagene, La Jolla, USA) was used as a reference and after reverse transcription as described above, coupled to Cy3 monofunctional dye (Amersham). Before hybridization, the Cy3-and Cy5-labeled samples were mixed 1:1. Samples were hybridized to silylated slides (CEL Associates, Houston, TX), printed by a PixSys 7500 arrayer (Cartesian Technologies, Durham, NC) with 2304 spots of cDNA derived from a subtracted cDNA library, enriched for genes which are expressed in differentiated and undifferentiated Caco-2 cells (Nur et al., 2002). Because a number of cDNA spots was corresponding to the same genes, approximately 1000 different genes were represented on the slides. After hybridization, the spots were scanned with the ScanArray Express HT scanner (Packerd Biosciences, Boston, USA). The fluorescence signals were quantified using ArrayVision software (Imaging Research, Ontario, Canada), exported to Microsoft Excel, and normalized first by correcting the Cy5 signals with the Cy3 internal standard signals. Subsequently, the median of the adjusted Cy5 values was used to correct for possible differences between experiments with respect to the efficiency of labeling and the amount of label. The corrected values 
were used for principle component analysis (PCA, GeneMath, Applied Maths, St-Martens-Latem, Belgium), a dimensioning technique that produces two- or three-dimensional plots in which the entries studied are spread according to their relatedness. The discriminant analyses calculates the best discriminating components for groups that are defined by the user, in our case the duplicate samples. For characterisation of the TCDD-induced gene expression profile, all genes of which the values of the duplicate exposures differed more than twice were excluded from analysis, and values of different spots representing the same genes were averaged. Because of the duplicate exposures of the cells to the samples, no statistical significance analysis was performed. Function of genes of interest were obtained from websites on http://us.expasy.org/sprot and http://www.ncbi.nlm.nih. gov.

\section{Real-time RT-PCR}

Two $\mu \mathrm{g}$ of total RNA was reverse transcribed into cDNA using $0.5 \mu$ random hexamer primers $(0.5$ $\mu \mathrm{g} / \mu \mathrm{l}$ ) and $1 \mu \mathrm{l}$ of $200 \mathrm{U} / \mu \mathrm{l}$ M-MLV reverse transcriptase (Invitrogen Life Technologies, Breda, The Netherlands) in a final volume of $20 \mu$ l. For amplification of $\beta$-actin, CYP1A1, CYP1B1, ODC1, MMP1, XAG, AR, DJ850, GLDC, and FGG (see for abbreviations) the following primers were used:

$\boldsymbol{\beta}$-Actin: forward 5'-GCTGGCCGGGACCTGACTGACTAC -3';

reverse 5'-CGCTCGGCCGTGGTGGTGAA -3';

CYP1A1: forward 5'-CCATGTCGGCCACGGAGTTTC-3';

reverse 5'-CATGGCCCTGGTGGATTCTTCA-3';

CYP1B1: forward 5'-TTCCAGTGAGGGCAGCAGGTGTCCA-3';

reverse 5'-GCGGGTTTAGCGGCCAAGGGTCGTT-3';

ODC1: forward 5'-ATGTGGGTGATTGGATGCTCTTTGA-3';

reverse 5'-TGCTGGCATCCTGTTCCTCTACTTC-3';

MMP1: forward 5'-CAAACCCCAAAAGCGTGTGA-3';

reverse 5'-ATCTCTGTCGGCAAATTCGTAAGC-3';

XAG: forward 5'-CAGAAATTGGCAGAGCAGTT-3';

reverse 5'-GCAGGTTCGTAAGCATAGAGAC-3';

AR: forward 5'-GTCTCCACTCGCTCTTCCAACACC-3';

reverse 5'-GAGCCGAGTATCAAGAGCGACAGC-3';

DJ850E9: forward 5'-GGCCTAACCCCATACCAGCAGT-3';

reverse 5'-GTATTTCССТСТTCССССТTТСТCT-3';

GLDC: forward 5'-GCGGCAGATCAATTTTCGGCTTTTT-3';

reverse 5'-GAACGGGCTGGTCCTCTTGAACACA-3';

FGG: forward 5'-CCTGGGACAATGACAATGATAAGT-3';

reverse 5'-TTCCAAGTGGCCCAAATAATG-3'.

$\beta$-Actin was used as the internal control for differences in efficiency during the reverse transcription. The real-time PCR was carried out using the iCycler PCR machine (Biorad, Veenendaal, The 
Netherlands) and the QuantiTect SYBR Green PCR kit (Qiagen, Hilden, Germany). Of each sample 6 dilutions were made based on the original amount of RNA: $0.781,1.563,3.125,6.25,12.5$, and 25 ng cDNA in $5 \mu$ l. Amplification was performed with $5 \mu$ diluted sample cDNA, $1 \mu$ of each primer $(10 \mu \mathrm{M})$ and 2x QuantiTect SYBR Green Master Mix in a final volume of $25 \mu \mathrm{l}$. The PCR products were checked by melt curve peak analysis and by gel electrophoresis. Gene expression levels were calculated from the threshold cycle values and expressed as the ratio with the $\beta$-actin expression level.

\section{RESULTS}

\section{Composition of the citrus extracts}

The composition of the extracts from dried citrus pulp and grapefruit juice was analysed by HPLCDAD to determine the content of reported and putative AhR agonists. The concentrations of these compounds, expressed in $\mu \mathrm{M}$ in exposure medium of the microarray experiment, are shown in Table 1. The medium with extract of citrus pulp (CPE) contained 5 different polymethoxyflavones in the lower micromolar range as well as $0.4 \mu \mathrm{M}$ of the furocoumarin bergamottin, while the medium with extract of grapefruit juice (GJE) contained much less polymethoxyflavones but 6.9 $\mu \mathrm{M}$ bergamottin. The chromatograms of both extracts revealed one other compound which has not yet been identified.

\section{Determination of the relative AhR-activating potency}

To assess their relative potencies to activate the transcription factor function of the AhR, the DR CALUX $^{*}$ assay was used to determine the response induced by citrus pulp and grapefruit juice extracts, ICZ, TCDD and B[a]P (Fig. 1). This reporter gene system utilises rat H4IIE hepatoma cells stably transfected with an AhR-controlled luciferase reporter gene, and enables quantification of the level of AhR-mediated gene expression. After 24 hours of exposure the $\mathrm{EC}_{50}$ of TCDD, being the concentration inducing a half-maximal response, was $15 \mathrm{pM}$. For ICZ a maximal response as high as that for TCDD was found with an $\mathrm{EC}_{50}$ of $8 \mathrm{nM}$, and $\mathrm{B}[\mathrm{a}] \mathrm{P}$ showed a maximum of $40 \%$ of that of TCDD and an $\mathrm{EC}_{50}$ of $89 \mathrm{nM}$. CPE and GJE showed maximum luciferase expression activation of ca. $60 \%$ and $50 \%$, respectively, compared to TCDD, although in the case of CPE no plateau level was reached. The extraction blank (ExBl) did not show any activation (Fig. 1).

Since the DR CALUX is based on H4IIE rat hepatoma cells, whereas the gene expression studies were carried out in human Caco-2 cells, the validity for Caco-2 cells of the optimal exposure levels established on the basis of the DR CALUX" assay could be seriously compromised by substantial differences in ligand binding affinity and transactivation properties between the rat and human AhR. Therefore, the 7-ethoxyresorufin-O-deethylase (EROD) induction assay was used to measure the activity of the AhR-responsive enzyme Cytochrome P4501A1 in Caco-2 cells (Fig. 2). The $\mathrm{EC}_{50}$ of TCDD for EROD induction in Caco-2 cells was 150 pM, which implies that this human cellline is tenfold less sensitive to AhR activation as compared to the H4IIE rat cells, in which similar $\mathrm{EC}_{50}$ values were found for EROD and luciferase induction (Hoogenboom et al., 1999). Within the 


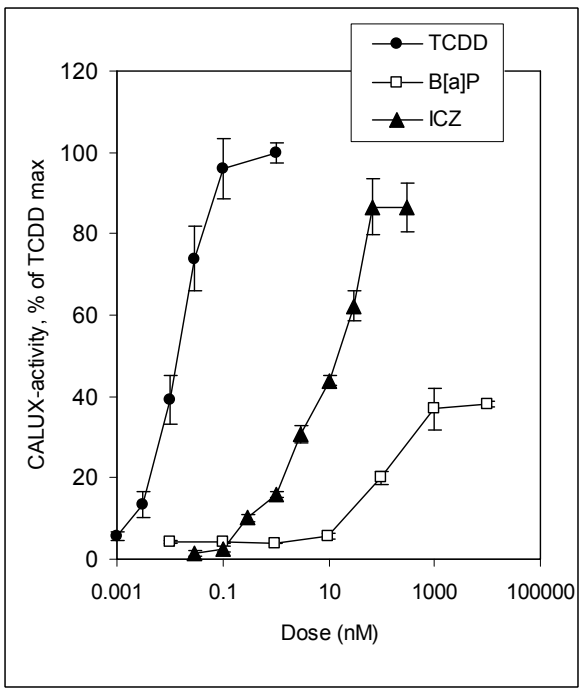

Fig. 1 A

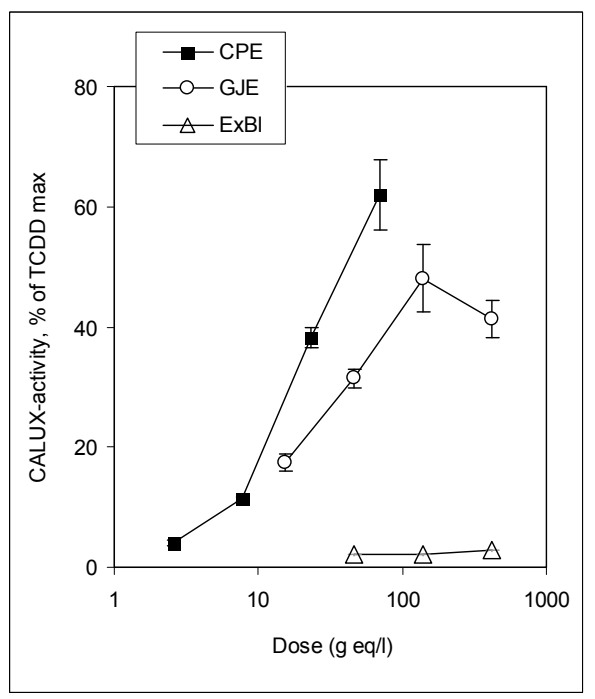

Fig. 1 B

Fig. 1. AhR agonist activity of TCDD, B[a]P and ICZ (A), and Citrus pulp and Grapefruit juice extracts (B) in rat H4IIE DR CALUX ${ }^{\star}$ cells. Exposure time was $24 \mathrm{~h}$, and results are expressed as percentage of the maximum response induced by TCDD. Error bars represent the standard deviation of triplicates. CPE, citrus pulp extract; GJE, grapefruit juice extract; ExBl, extraction blank.

ICZ concentration range used, the EROD induction did not reach a maximum, but extrapolation of the fitted curve indicated that only ca $74 \%$ of the maximum response level reached by TCDD could be attained at higher ICZ concentrations with an $\mathrm{EC}_{50}$ of ca. $42 \mathrm{nM}$. B[a]P had a maximum EROD induction level of $28 \%$. The activation decreased above $300 \mathrm{nM}$, most likely due to the EROD activity-inhibiting properties of $\mathrm{B}[\mathrm{a}] \mathrm{P}$ (Bosveld et al., 2002) (Fig. 2).

Table 1. Composition of the citrus pulp and grapefruit juice extracts as determined by HPLC

\begin{tabular}{lll}
\hline & Conc. $(\mu \mathrm{M})$ & \\
& CPE & GJE \\
\hline Sinensetin & 0.9 & $<0.1$ \\
Tetramethylscutellarein /nobiletin & 1.8 & $<0.1$ \\
Heptamethoxyflavone & 4.3 & $<0.1$ \\
Tangeretin & 1.7 & 0.1 \\
Bergamottin & 0.4 & 6.9 \\
\hline
\end{tabular}

Note. Concentrations are calculated as $\mu \mathrm{M}$ in the exposure medium of the Caco- 2 cells used for the microarray analysis. The medium contained the equivalent of 208 gram dried citruspulp or 417 gram grapefruit juice per liter. Tetramethylscutellarein and nobiletin could not be separated and therefore the sum of their concentrations is given.

CPE, citrus pulp extract; GJE, grapefruit juice extract. 


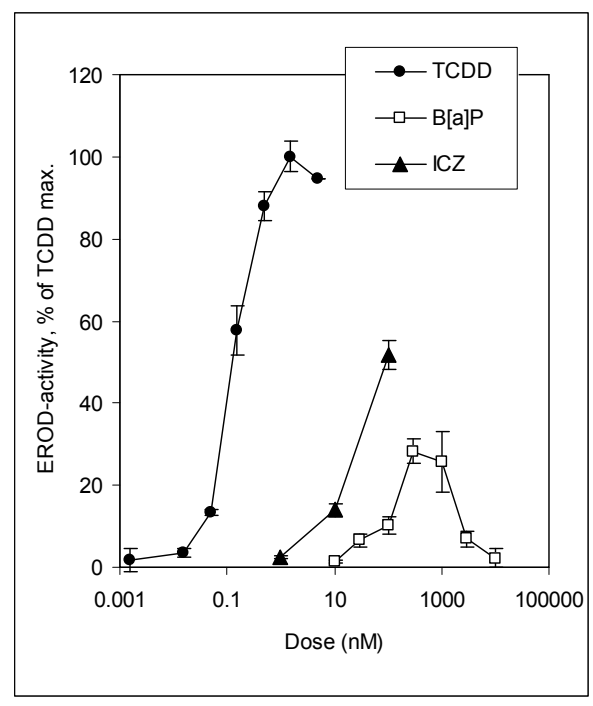

Fig. 2 A

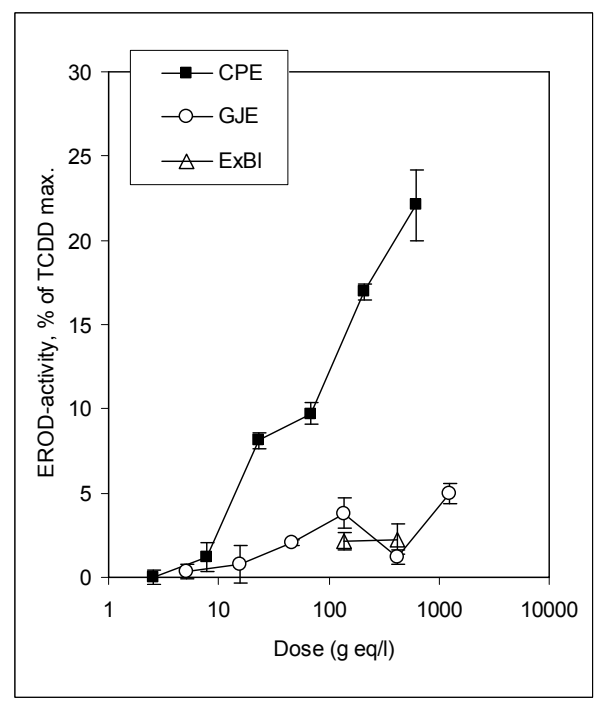

Fig. 2 B

Fig. 2. EROD activity induced by TCDD, B[a]P and ICZ (A), and Citrus pulp and Grapefruit juice extracts (B) in human Caco-2 cells. Exposure time was $24 \mathrm{~h}$, and results are expressed as percentage of the maximum response induced by TCDD. Error bars represent the standard deviation of triplicates. CPE, citrus pulp extract; GJE, grapefruit juice extract; ExBl, extraction blank.

CPE showed an EROD activation of $25 \%$ of the TCDD-maximum, but did not reach a plateau level within the tested concentration range. GJE did not induce a clearly increased activity (Fig. 2). It was hypothesized that this could be due to the presence of EROD-inhibiting compounds, like bergamottin (Baumgart et al., 2005). In order to confirm this, the EROD-induction by mixtures of TCDD and GJE was measured. Indeed, Fig. 3 shows a concentration-dependent inhibition of the effect of TCDD by the grapefruit juice extract.

\section{Modulation of gene expression by NAhRAs and xenobiotic dioxin-like compounds}

To investigate the overlap in the gene expression profiles induced by NAhRAs and by the persistent reference compound TCDD or the readily biodegradable Ah-receptor agonist B[a]P, Caco-2 cells were exposed during 24 hours to $500 \mathrm{pM}$ TCDD, $1 \mu \mathrm{M} \mathrm{B}$ [a]P, $100 \mathrm{nM} \mathrm{ICZ}$ and citrus-extracts (208 $\mathrm{g} / \mathrm{l}$ citrus pulp extract, $417 \mathrm{~g} / \mathrm{l}$ grapefruit juice extract or $417 \mathrm{~g} / \mathrm{l}$ blank extract) at concentration levels based on a significant response level in the DR CALUX' and EROD analysis with Caco- 2 cells. The logarithm of the microarray fluorescence signals was imported into the GeneMaths program, and principal component analysis with discriminant was performed and plotted in a 3-D diagram, in which a total gene expression profile is represented by a dot (Fig. 4). The profiles for TCDD, B[a] $\mathrm{P}$ and the NAhRAs are clearly separated from those of the solvent DMSO and the blank extraction which cluster together. In particular the gene expression profiles induced by ICZ, GJE, and one of the $\mathrm{B}[\mathrm{a}] \mathrm{P}$ duplicates appear to plot very close to TCDD. 


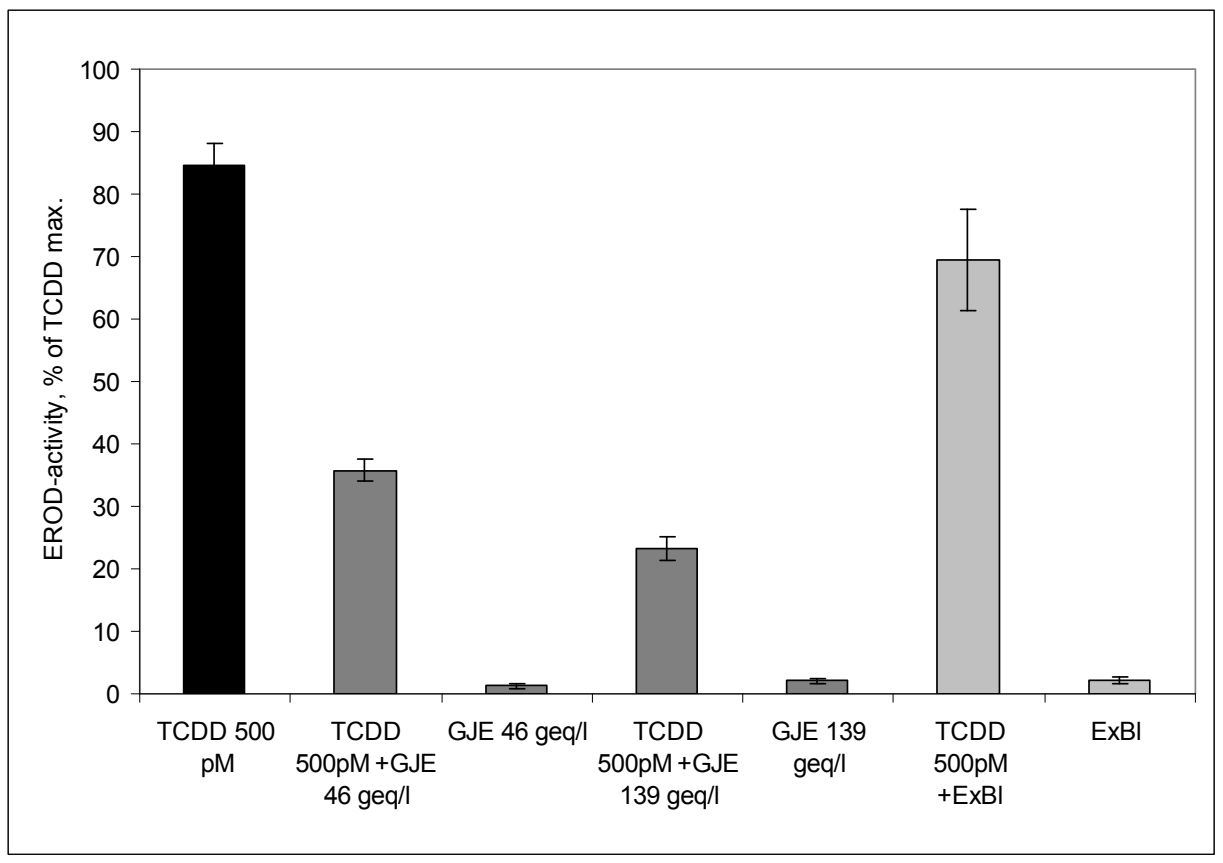

Fig. 3. Concentration-dependent inhibition of EROD-activity in Caco-2 cells by grapefruit juice extract (GJE). A TCDD-spiked blank extract did not show EROD inhibition (ExBl + 500 pM TCDD, P>0.05, Student's t-test), while the inhibiting effects of both GJE concentrations + 500 pM TCDD were highly significant $(\mathrm{P}<0.001)$. Error bars represent the standard deviation of triplicate exposures. The maximum effect of TCDD is the same as shown in Fig. 2.

In order to look for the genes affected by TCDD treatment versus treatment with the solvent only, all genes which were up- or down-regulated more than 1.5 times by TCDD were selected. In this way 22 TCDD-responsive genes were identified (Table 2). Table 2 includes the induction factors observed with the other compounds and extracts tested, and the functions and involvement in metabolic pathways of the responsive genes. CYP1B1 was added as no 23, despite an induction factor of only 1.4, because it is known from literature to be strongly up-regulated by TCDD (Hankinson, 1995; Spencer et al., 1999; Martinez et al., 2002) and showed a larger induction factor by using RT-PCR (see next paragraphe). Most of the responsive genes that were found to be up-regulated by TCDD, are known to be involved in biotransformation, growth, cell proliferation, stress or the acute phase response.

In Fig. 5, gene expression ratios versus $\mathrm{DMSO}$ or $\mathrm{ExBl}$ are plotted from strongest up-regulation to strongest down-regulation by TCDD. The gene expression ratios found for TCDD (Fig. 5A) lie well above the profile for the DMSO control, and $\mathrm{B}[\mathrm{a}] \mathrm{P}$ and ICZ induced very similar gene expression profiles compared with TCDD. The citrus extracts were plotted against the blank extract (Fig. 5B). As shown in Fig 5A, the gene expression induced by the extract of the blank sample plotted against DMSO generated a profile which presented an insignificant experimental noise around the DMSO-line, indicating that the extraction procedure as such had not introduced any effect on gene 


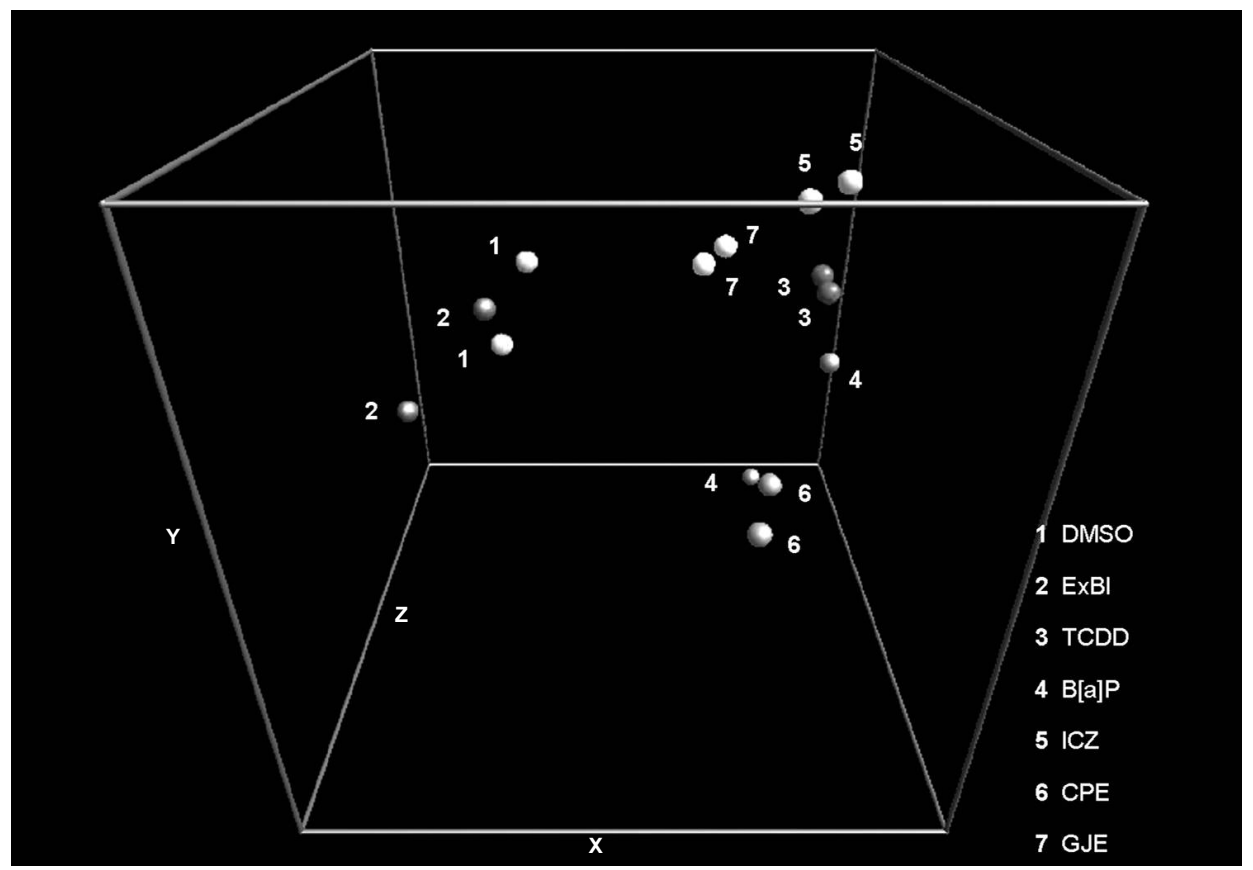

Fig. 4. Three-dimensional plot of principal component analysis (PCA) with discriminant from all 2304 spots of the Caco-2 microarray after $24 \mathrm{~h}$ exposure of Caco-2 cells to TCDD, benzo[a]pyrene, ICZ and citrus extracts. The total gene expression pattern is visualized as a numbered dot; equal numbers represent duplicate exposures to the tested compound. X, Y and Z-axes represent the 1st, 2nd and 3rd principal component resp.

expression. As shown in Fig. 5B, the CPE and GJE up- or down-regulated most of the 23 dioxinresponsive genes in the same direction as TCDD. For 5 of these genes (AR, SLC20A1, FOS, PDZK1 and GLDC), exposure to CPE showed no or little effect, while GJE appeared not to affect 7 of these genes (MMP1, AR, DJ850E9, CYP1B1, GLDC, DIPP and SCAMP1). GLDC was also not affected by $\mathrm{B}[\mathrm{a}] \mathrm{P}$ and ICZ, and thus appeared to be specific for TCDD exposure. Genes that were more than 1.5 times up- or down-regulated by ICZ or the citrus extracts, but less than 1.5 times by TCDD, are not presented here, because they are unlikely to be dioxin toxicity-related genes and although interesting, beyond the scope of this study. However, preliminary analysis within this gene category showed that again mainly small differences between the responses induced by the NAhRAs and by TCDD were found (results not shown).

\section{Real-time RT-PCR confirmation}

Quantitative real-time Reverse Transcription PCR was used in order to validate the results of the microarray experiment. For this purpose 10 genes were selected: 9 of the 23 dioxin responsive genes and $\beta$-actin as a housekeeping gene for normalization. Nearly all results of the microarray analysis that were checked by real-time RT-PCR were clearly confirmed with respect to the up- or down-regulation of the gene expression (Fig. 6). The only qualitative difference was observed for 


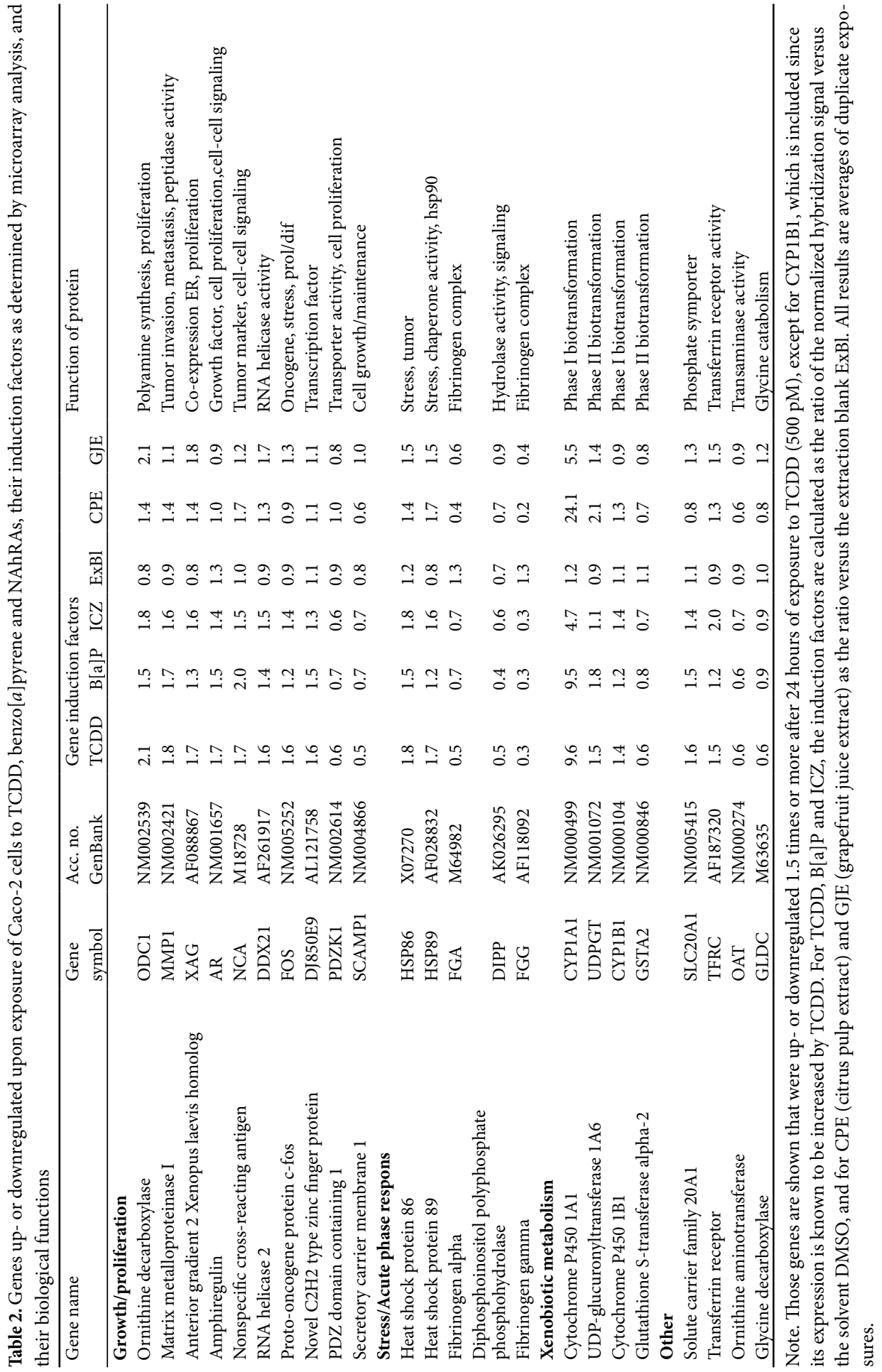




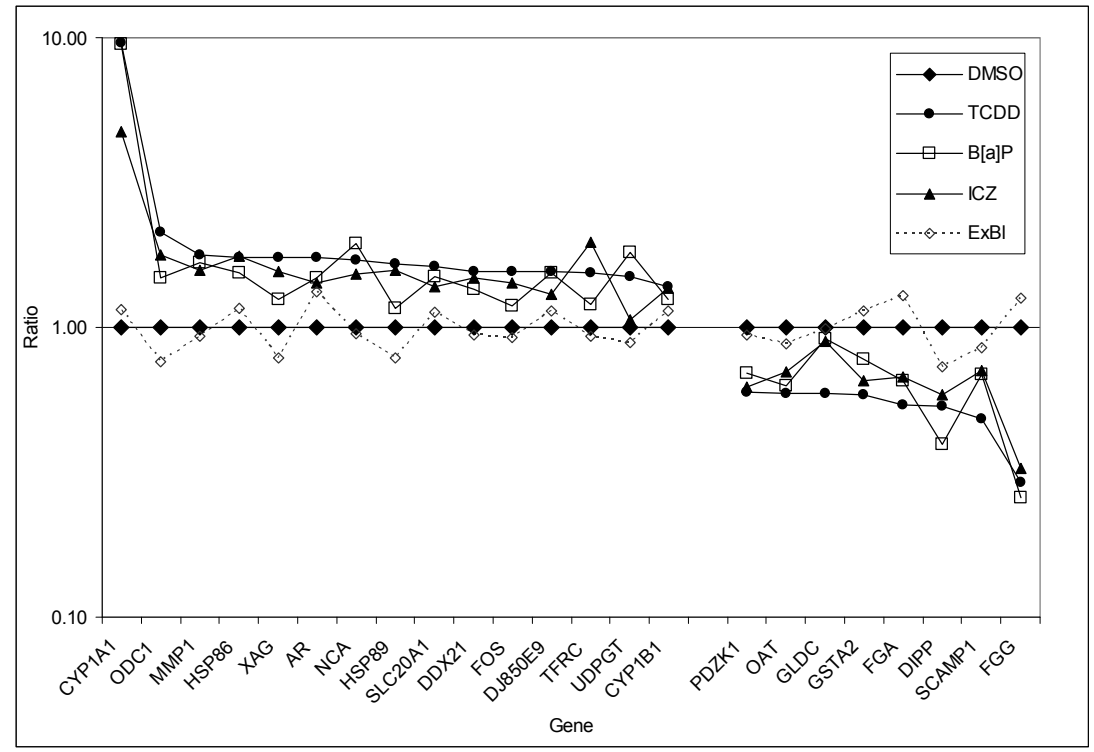

Fig. 5 A

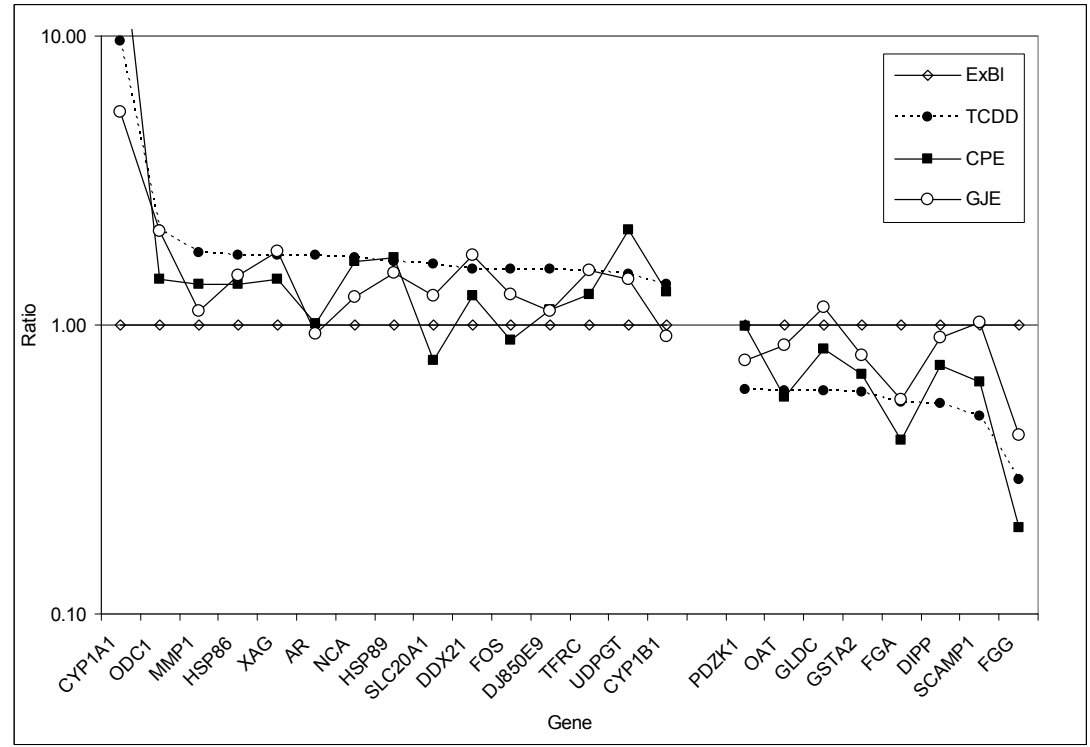

Fig. 5 B

Fig. 5. Gene expression profiles from microarray results. Expression characteristics are shown for CYP1B1 and 22 dioxin-responsive genes that were found by microarray analysis to be up- or down-regulated 1.5 times or more upon exposure of Caco-2 cells to $500 \mathrm{pM}$ TCDD. A: Gene induction factors calculated versus the solvent DMSO upon exposure to TCDD, B[a]P, ICZ and ExBl. B: Gene induction factors calculated versus the extraction blank $(\mathrm{ExBl})$ upon exposure to extracts of citrus pulp (CPE) and grapefruit juice (GJE). All dots represent averages of duplicate exposures. 


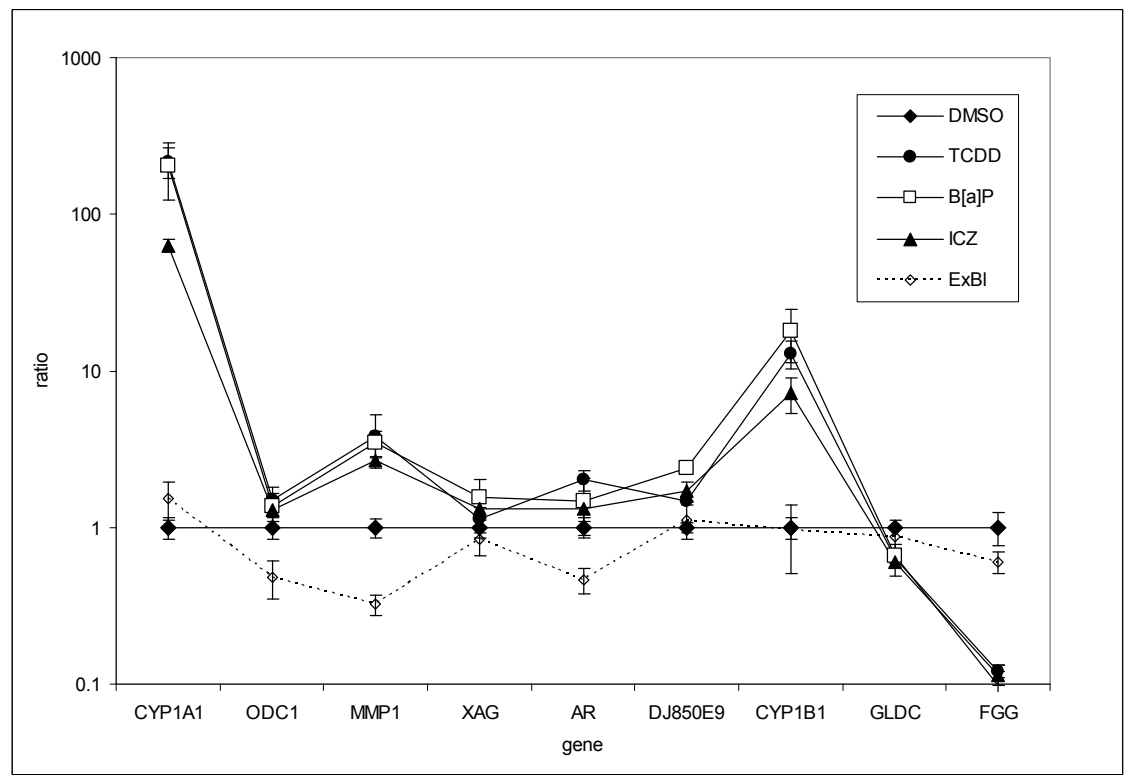

Fig. $6 \mathrm{~A}$

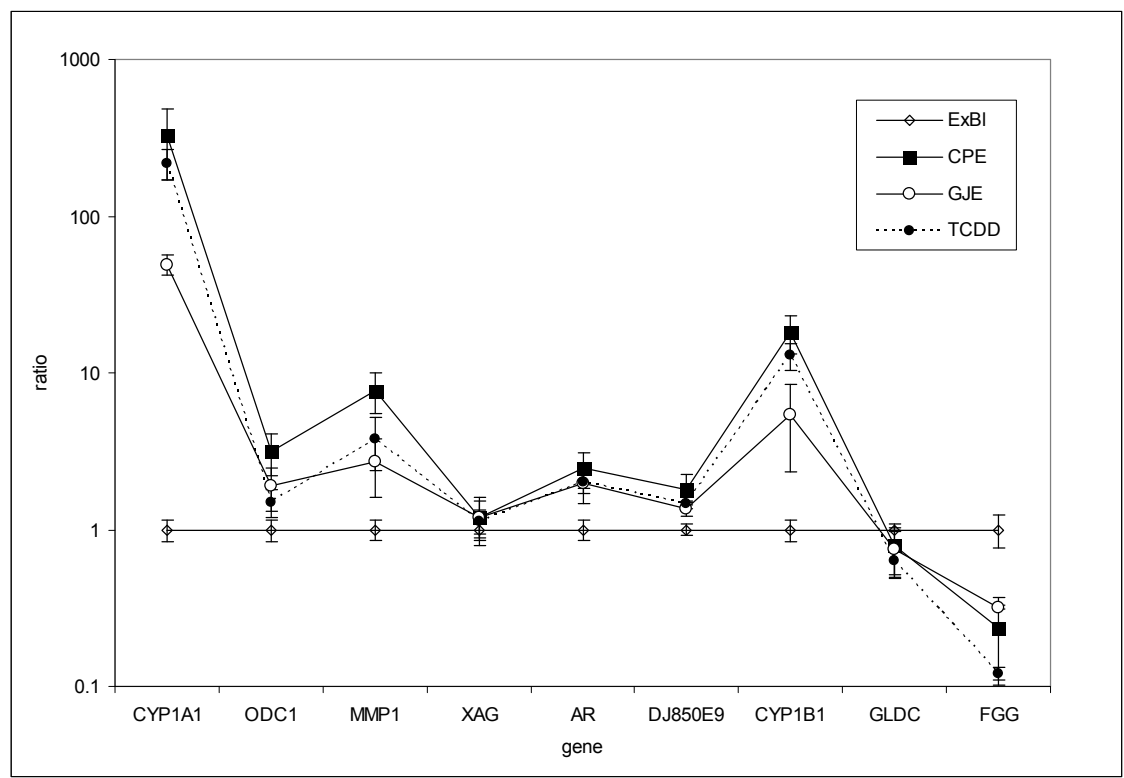

Fig. 6 B

Fig. 6. Gene expression characteristics of nine genes as determined by real-time RT-PCR. A: Gene induction factors calculated versus the solvent DMSO upon 24h of exposure of Caco-2 cells to TCDD, B [a]P, ICZ and ExBl. $\mathrm{B}$ : Gene induction factors versus the extraction blank (ExBl) upon exposure of Caco-2 cells to extracts of citrus pulp (CPE) and grapefruit juice (GJE). Error bars represent standard deviations of 2 to 5 measurements. 
Table 3. Induction factors of nine genes responsive in Caco-2 cells upon exposure to TCDD, B[a]P or NAhRAs as determined by real-time RT-PCR, or microarray analysis without or with background subtraction (MA and MA-BS, respectively).

\begin{tabular}{|c|c|c|c|c|c|c|c|c|c|c|c|c|c|c|c|c|c|c|}
\hline & \multicolumn{6}{|c|}{ TCDD } & \multicolumn{6}{|c|}{$\mathrm{B}[\mathrm{a}] \mathrm{P}$} & \multicolumn{6}{|c|}{ ICZ } \\
\hline & mean & sd & & $\mathbf{n}$ & MA & MA-BS & mean & sd & & $\mathbf{n}$ & MA & MA-BS & mean & sd & & $\mathbf{n}$ & MA & MA-BS \\
\hline CYP1A1 & 218.1 & 47.9 & $* * *$ & 4 & 9.6 & 51.8 & 205.2 & 81.5 & $* * *$ & 4 & 9.5 & 53.0 & 63.3 & 5.4 & $* * *$ & 4 & 4.7 & 22.4 \\
\hline ODC1 & 1.50 & 0.31 & ** & 4 & 2.1 & 2.4 & 1.38 & 0.28 & $* *$ & 4 & 1.5 & 1.9 & 1.28 & 0.28 & * & 4 & 1.8 & 1.8 \\
\hline MMP1 & 3.55 & 0.88 & $* * *$ & 4 & 1.8 & 3.7 & 3.47 & 0.61 & * & 2 & 1.7 & 2.9 & 2.68 & 0.12 & $* *$ & 2 & 1.6 & 2.6 \\
\hline XAG & 1.13 & 0.20 & & 4 & 1.7 & 1.5 & 1.57 & 0.44 & $* *$ & 4 & 1.3 & 1.3 & 1.32 & 0.19 & $* *$ & 4 & 1.6 & 1.2 \\
\hline AR & 2.02 & 0.31 & $* * *$ & 5 & 1.7 & 2.2 & 1.48 & 0.59 & * & 5 & 1.5 & 2.1 & 1.31 & 0.22 & $* *$ & 5 & 1.4 & 1.8 \\
\hline DJ850E9 & 1.47 & 0.02 & $* * *$ & 2 & 1.6 & 1.4 & 2.38 & 0.09 & $* *$ & 2 & 1.5 & 1.9 & 1.71 & 0.24 & * & 2 & 1.3 & 1.3 \\
\hline CYP1B1 & 12.25 & 2.43 & $* * *$ & 5 & 1.4 & 6.5 & 14.38 & 7.14 & $* *$ & 4 & 1.2 & 4.9 & 4.99 & 2.72 & $* *$ & 4 & 1.4 & 6.0 \\
\hline GLDC & 0.64 & 0.15 & * & 2 & 0.6 & 0.9 & 0.66 & 0.03 & $* *$ & 2 & 0.9 & 1.1 & 0.60 & 0.00 & $* * *$ & 2 & 0.9 & 0.8 \\
\hline \multirow[t]{3}{*}{ FGG } & 0.12 & 0.01 & $* * *$ & 2 & 0.3 & 0.3 & 0.10 & 0.02 & $* * *$ & 2 & 0.3 & 0.3 & 0.11 & 0.02 & $* * *$ & 2 & 0.3 & 0.3 \\
\hline & \multicolumn{6}{|c|}{ ExBI } & \multicolumn{6}{|c|}{ CPE } & \multicolumn{6}{|c|}{ GJE } \\
\hline & mean & sd & & $\mathbf{n}$ & MA & MA-BS & mean & sd & & $\mathbf{n}$ & MA & MA-BS & mean & sd & & $\mathbf{n}$ & MA & MA-BS \\
\hline CYP1A1 & 1.54 & 0.42 & * & 3 & 1.2 & 0.9 & 326.0 & 156.3 & $* *$ & 4 & 24.1 & 165.6 & 49.2 & 7.0 & $* * *$ & 4 & 5.5 & 34.0 \\
\hline ODC1 & 0.48 & 0.13 & $* * *$ & 4 & 0.8 & 0.9 & 3.15 & 0.93 & $* * *$ & 4 & 1.4 & 1.4 & 1.89 & 0.59 & $* *$ & 4 & 2.1 & 1.9 \\
\hline MMP1 & 0.40 & 0.13 & $* * *$ & 5 & 0.9 & 1.0 & 6.33 & 1.87 & * & 2 & 1.4 & 2.3 & 2.20 & 0.89 & & 2 & 1.1 & 1.4 \\
\hline XAG & 0.84 & 0.18 & * & 4 & 0.8 & 0.7 & 1.20 & 0.31 & & 4 & 1.4 & 1.3 & 1.19 & 0.40 & & 4 & 1.8 & 1.5 \\
\hline AR & 0.46 & 0.08 & $* * *$ & 5 & 1.3 & 1.8 & 2.48 & 0.63 & $* * *$ & 5 & 1.0 & 0.8 & 1.96 & 0.49 & $* * *$ & 5 & 0.9 & 0.9 \\
\hline DJ850E9 & 1.12 & 0.28 & & 2 & 1.1 & 0.9 & 1.81 & 0.46 & & 2 & 1.1 & 1.4 & 1.37 & 0.15 & * & 2 & 1.1 & 1.5 \\
\hline CYP1B1 & 0.81 & 0.41 & & 3 & 1.1 & 4.5 & 21.58 & 6.06 & * & 2 & 1.3 & 1.5 & 6.58 & 2.13 & $* * *$ & 4 & 0.9 & 1.0 \\
\hline GLDC & 0.87 & 0.25 & & 2 & 1.0 & 1.1 & 0.79 & 0.30 & & 2 & 0.8 & 0.7 & 0.75 & 0.24 & & 2 & 1.2 & 1.0 \\
\hline FGG & 0.60 & 0.10 & * & 2 & 1.3 & 1.2 & 0.24 & 0.13 & $* *$ & 2 & 0.2 & 0.2 & 0.32 & 0.01 & $* * *$ & 2 & 0.4 & 0.4 \\
\hline
\end{tabular}

Note. ${ }^{*} \mathrm{P}<0.1 ;{ }^{* *} \mathrm{P}<0.05 ;{ }^{* *} \mathrm{P}<0.01$ (Student's t-test; when $\mathrm{n}=2$, it can only be considered as an indication); n, number of RT-PCR replicates; CPE, extract of citrus pulp; GJE, extract of grapefruit juice.

XAG, for which the RT-PCR, in contrast to the microarray, did not show up-regulation for most of the samples. To rule out malfunction of the used primer pair, another primer pair for XAG was developed with a different annealing site in the mRNA, however with the same results. Possibly, the up-regulation detected on the microarray was a false positive.

In addition, a few quantitative discrepancies were observed. In contrast to the non-conclusive microarray results, the genes for MMP1, AR, and DJ850E9 were found to be clearly up-regulated by GJE when measured by RT-PCR. AR was also found up-regulated by CPE (Table 3). Another remarkable result was that the ratio of 12.3 measured with RT-PCR for CYP1B1 induction by TCDD is much higher than the microarray result of 1.4 , and also for the other compounds high ratios were found (5.0 - 21.6). The same holds for CYP1A1 (ratio for TCDD of 218 by RT-PCR versus 9.6 by microarray) and, to a lesser extent, for MMP1. A likely explanation for these discrepancies is that for the microarray analysis background subtraction had not been applied, because this resulted in a much higher variability than found with the overall signal values. Since CYP1A1, CYP1B1 and MMP1 had very low baseline expression levels, which produced only a small signal increase, subtraction of the background from the microarray signal has a relatively large influence on the exposed to control signal ratio. When including background subtraction in the analysis of the microarray data, the ratios found for these 3 genes increased considerably (Table 3). The lack of CYP1B1 induction, a known AhR-regulated gene, by TCDD, B[a]P and NAhRAs, as indicated by some microarray results, was contradicted by the RT-PCR control (Table 3 ). 
In contrast to the microarray analysis, the RT-PCR also revealed that the 1.6 times down-regulation of GLDC by TCDD was not specific for TCDD, because all the other compounds were shown to down-regulate this gene too by 1.3-1.7 times (Table 3).

\section{Discussion}

Many food items have been shown to contain high levels of Ah-receptor agonist activity, as judged by the DR CALUX" bioassay (Jeuken et al., 2003). Furthermore several natural occurring compounds, or their acid reaction products, have been confirmed to be AhR-agonists (Bjeldanes et al., 1991; Baumgart et al., 2005). Currently, it is still unclear what causes the apparent profound difference in biological effects between NAhRAs and xenobiotic AhR agonists, and whether this is just a matter of the persistence of the compound in living cells and organisms, or whether additional differences in gene expression effects or of other nature are more crucial. As a result, it is hard to predict on the basis of current knowledge whether a substantial increase in the consumption of NAhRAs because of their presumed beneficial health effects would imply a risk for unexpected adverse AhR-mediated side effects.

Gene expression profiling using microarray technology may provide valuable, transcriptome-wide information about potential similarities or differences in the gene expression effects of compounds (Aardema and MacGregor, 2002). As a first step in evaluating the hypothetical adverse effects of NAhRAs in humans, the purpose of this study was to compare gene expression patterns in a human cell-line exposed to NAhRAs in comparison to those elicited by the well-known xenobiotic AhR agonists TCDD and benzo[a]pyrene $(\mathrm{B}[\mathrm{a}] \mathrm{P})$. The latter compound was included in these studies, because it is rapidly metabolised compared with TCDD, and is thus expected to be comparable to NAhRAs in this respect. Therefore, if NAhRAs would turn out to induce a gene expression pattern which is clearly more related to that of $\mathrm{B}[\mathrm{a}] \mathrm{P}$ than to that of TCDD, this would indicate that the biological stability is a possible determinant of the difference in biological effect observed between NAhRAs and persistent AhR agonists such as TCDD. However, under the present conditions and despite the relatively long incubation period of $24 \mathrm{~h}$, both the NAhRAs and B[a]P were found to display a gene expression profile similar to that of TCDD (Table 2, Fig. 5 and Fig. 6). This precludes any conclusion concerning the role of compound stability in the difference in biological effects between NAhRAs and TCDD. This may be a reflection of the predominance on the gene expression level of the dioxin-like toxic effects described for B[a]P-like PAHs, such as immunotoxicity and teratogenicity (Burchiel and Luster, 2001), indicating that NAhRAs may have at least the potential to cause similar effects.

TCDD exposure leads to various effects in which up- and down-regulation of many different genes appear to play a role, although a clear mechanistic view of TCDD-related effects has not been obtained thus far. The most extensively investigated genes known to be affected by exposure to dioxins are those involved in phase I and II biotransformation, like cytochrome P450s 1A1, 1A2, 1B1, and UDPglucuronyl transferase 1A6 (Hankinson, 1995; Nebert et al., 2000). Biotransformation enzymes play an important role in the detoxification of xenobiotic compounds, but some of them may also cause 
negative effects on health, e.g. due to the production of toxic metabolites like genotoxic electrophiles and oxygen radicals (Agundez, 2004). In our study with the microarrays CYP1A1, CYP1B1 and UDPGT $1 \mathrm{~A} 6$ were upregulated by all tested AhR agonists. Also many other genes, such as those related to signaling pathways, transcription factors, differentiation, apoptosis, cell development, cell adhesion, cancer and metastasis have been shown to be differentially regulated by TCDD (Hankinson, 1995; Nebert et al., 2000; Puga et al., 2000; Frueh et al., 2001). Ten out of the 23 dioxin responsive genes in this study appear to be involved somehow in cell proliferation and are modulated by TCDD in the direction that they may stimulate tumor formation. ODC1, up-regulated 1.3-3.2 times by all tested AhR agonists (Table 3), is found elevated in human colorectal tumors and polyps (Radford et al., 1990), and the use of ODC1 inhibitors has been proposed as a strategy for colon cancer prevention (Martinez et al., 2003). MMP1, up-regulated 2.2-6.3 times by all test samples (Table 3), is a collagenase and plays a key role in matrix deposition and tissue remodeling that occurs constantly in both normal and diseased conditions. The expression of MMP1 is an important factor related to tumor invasion and metastasis in colorectal carcinoma (Malhotra et al., 2002). This gene is also up-regulated by TCDD in the human HPL1A cell-line and in normal human keratinocytes (Martinez et al., 2002; Murphy et al., 2004). In the study of Murphy et al., activation of the AhR pathway by TCDD was shown to interfere with the retinoic acid signaling in the skin, which may play a role in the development of skin disorders like acne. Puga et al. relate AhR-activity with retinoic acid function and the teratogenic effect of cleft palate induction in offspring of mice after TCDD administration (Puga et al., 2005). Amphiregulin (AR) was up-regulated 1.3-2.5 times by all compounds and extracts (Table 3 ). The gene product is a member of the epidermal growth factor family and an autocrine growth factor for human keratinocytes. The expression of AR is increased in psoriatic epidermis and considered central in the development of this skin disease (Shoyab et al., 1989; Cook et al., 1997). AR is also a specific ligand of ERBB (encoding a tyrosine kinase growth factor receptor), and ERBB pathway disregulation is associated with breast cancer (Bieche et al., 2003). A role of AhR-mediated AR disregulation in breast cancer development would also be consistent with the notion that TCDD might have an inhibitory effect on mammary carcinogenesis (Safe et al., 2000; Safe and Wormke, 2003). DJ850E9 is a novel C2H2-type zinc finger protein which represents a large class of DNA-binding proteins and transcription factors and may be involved in hematopoiesis, oncogenesis, and immune responses (Zhang et al., 2001). Nonspecific cross-reacting antigen (NCA) functions as an intercellular adhesion molecule and overexpression can contribute to colon tumorigenesis (Ilantzis et al., 2002). Increase of mRNA levels of the proto-oncogene $c$-fos by exposure to TCDD has been shown in mouse hepatoma cells (Hoffer et al., 1996), and by B[a]P in human prostate carcinoma cells (Kizu et al., 2003). Fibrinogen alpha (FGA) and fibrinogen gamma (FGG) were down-regulated by all AhR agonists and this down-regulation by TCDD was already reported in human HepG2 cells (Wang et al., 1996; Frueh et al., 2001). Fibrinogen acts as a cofactor in platelet aggregation, but is also an acute-phase protein (Koenig, 2003). Down-regulation of FGG may be related to the immunosuppressive activity of TCDD. 
Most of the genes found to be affected in our study are theoretically involved in disease processes, and possibly also in some of the reported toxic effects, especially tumor promotion, exerted by $\mathrm{I} 3 \mathrm{C}$ and ICZ in vitro and in vivo (Dashwood, 1998; Herrmann et al., 2002; Yoshida et al., 2004). As with most, if not all, in vitro studies, our results can not be extrapolated directly to human in vivo exposure, because of the lack of factors at the tissue and organ level present in the intact organism. At the same time, the concentrations of NAhRAs and their tissue distribution in the human body are unknown. However, a preliminary and rough estimate of the internal exposure can be performed by using the dose-response curves of TCDD and e.g. the grapefruit juice extract. According to the DR CALUX' results, the amount of AhR agonists in one glass of grapefruit juice would show the same DR CALUX' response as 2000 pg TCDD. This would be a substantial amount, for the tolerable daily intake was established by the WHO at $14 \mathrm{pg}$ TCDD equivalents (TEQ) $/ \mathrm{kg}$ bw/week, which corresponds to $140 \mathrm{pg}$ TEQ/day for a person of $70 \mathrm{~kg}$ (JECFA, 2002). Human studies showed that consumption of cruciferous vegetables or pills with pure indole-3-carbinol appear to affect the AhR pathway (Kall et al., 1996; Sepkovic et al., 2001). So, despite that NAhRAs need much higher concentrations than TCDD for AhR activation, and probably have much shorter half-lives, humans can have a regular, and therefore prolonged, exposure to effective concentrations in the diet, especially when considering food supplements with a high NAhRA content.

Although most of the genes affected by NAhRAs in our study were also affected by TCDD (and vice versa), and possibly play a role in certain diseases, a microarray study, such as presented here, does not provide conclusive insight in the health impact of NAhRAs, because it is only directed to the transcriptome level. To enable conclusions on possible toxic effects, additional information on the impact of the observed transcriptional effects on the proteome level and toxic endpoints is necessary (Heijne et al., 2003). The inhibition of the EROD-activity by GJE (Fig. 3) is an example where the up-regulation of the expression of a gene (CYP1A1) did not result in an increased expression of the encoded biological function (EROD enzymatic activity). It is not unlikely that NAhRAs also have post-translational modulating effects on the biological functions of proteins other than CYP1A1. Furthermore, it needs to be clarified to what extent the gene expression profiles obtained in the Caco-2 cell-line may be extrapolated to AhR-responsive cells and tissues in vivo in the context of the complex physiological interactions and kinetics within the complete human body. Since our microarray did only cover about 1000 different genes, it cannot be ruled out that the effect of NAhRAs on the expression of other genes causes differential biological effects as compared with TCDD. Notwithstanding that, our results show that coordinated expression of e.g. CYP1B1, MMP1, $\mathrm{AR}$ and FGG genes may serve as a biomarker for exposure to AhR agonists.

In conclusion, this study shows that NAhRAs, TCDD and B[a]P modulate the expression of a largely overlapping set of genes in Caco-2 cells, and that, for the set of genes represented on the microarrays used, a clear distinction between the gene expression profiles induced by these different AhR agonists can not be demonstrated. This implies that the thus far reported differences in biological activity between NAhRAs and xenobiotic AhR agonists are either the result of differences in gene expression effects beyond the scope of this study, or caused by effects beyond the transcriptome level, or due 
to the kinetics of these compounds in the body. Further investigations should therefore be directed towards a more comprehensive transcriptome-wide comparison of the gene transcription effects of NAhRAs versus xenobiotic AhR agonists, complemented by the assessment of the levels and biological activities of the proteins encoded by the identified responsive genes, and studies on the fate and effects of these compounds in animals and humans. This strategy would provide insight into the balance between healthy and unhealthy pathways affected. Based on these new insights, a sound risk-benefit assessment for regular intake of food items with high NAhRA content can be made.

\section{ACKnowledgements}

The authors thank prof. J. Bergman, Department of Chemistry, Royal Institute of Technology, and Department of Biosciences at Novum, Huddinge, Sweden for kindly providing the ICZ-reference substance, and Gerrit Bor, Liza Portier and Astrid Hamers for their technical assistance. The Dutch Centre of Human Nutrigenomics (CHN) supported this study. 


\section{REFERENCES}

Aardema, M. J., and MacGregor, J. T. (2002). Toxicology and genetic toxicology in the new era of "toxicogenomics": impact of “-omics” technologies. Mutat Res 499, 13-25.

Aarts, J. M., Denison, M. S., Cox, M. A., Schalk, M. A., Garrison, P. M., Tullis, K., de Haan, L. H., and Brouwer, A. (1995). Species-specific antagonism of Ah receptor action by 2,2'5,5'-tetrachloro- and 2,2'3,3'4,4'-hexachlorobiphenyl. Eur J Pharmacol 293, 463-474.

Agundez, J. A. (2004). Cytochrome P450 gene polymorphism and cancer. Curr Drug Metab 5, 211-224.

Baumgart, A., Schmidt, M., Schmitz, H. J., and Schrenk, D. (2005). Natural furocoumarins as inducers and inhibitors of cytochrome P450 1A1 in rat hepatocytes. Biochem Pharmacol 69, 657-667.

Bergman, J. (1970). Condensation of indole and formaldehyde in the presence of air and sensitizers. Tetrahedron 26, 3353-3355.

Bergman, J., Janosik, T., and Wahlstrom, N. (2001). Indolocarbazoles. In: Advances in heterocyclic chemistry, Academic Press. 80, 1-71.

Bieche, I., Onody, P., Tozlu, S., Driouch, K., Vidaud, M., and Lidereau, R. (2003). Prognostic value of ERBB family mRNA expression in breast carcinomas. Int J Cancer 106, 758-765.

Bjeldanes, L. F., Kim, J. Y., Grose, K. R., Bartholomew, J. C., and Bradfield, C. A. (1991). Aromatic hydrocarbon responsiveness-receptor agonists generated from indole-3-carbinol in vitro and in vivo: comparisons with 2,3,7,8-tetrachlorodibenzo-p-dioxin. Proc Natl Acad Sci U S A 88, 9543-9547.

Bosveld, A. T., de Bie, P. A., van den Brink, N. W., Jongepier, H., and Klomp, A. V. (2002). In vitro EROD induction equivalency factors for the 10 PAHs generally monitored in risk assessment studies in The Netherlands. Chemosphere 49, 75-83.

Bovee, T. F., Hoogenboom, L. A., Hamers, A. R., Traag, W. A., Zuidema, T., Aarts, J. M., Brouwer, A., and Kuiper, H. A. (1998). Validation and use of the CALUX-bioassay for the determination of dioxins and PCBs in bovine milk. Food Addit Contam 15, 863-875.

Broadbent, T. A., and Broadbent, H. S. (1998). 1 - 1. The chemistry and pharmacology of indole-3-carbinol (indole-3-methanol) and 3-(methoxymethyl)indole. [Part I]. Curr Med Chem 5, 337-352.

Burchiel, S. W., and Luster, M. I. (2001). Signaling by environmental polycyclic aromatic hydrocarbons in human lymphocytes. Clin Immunol 98, 2-10.

Burke, M. D., and Mayer, R. T. (1974). Ethoxyresorufin: direct fluorimetric assay of a microsomal O-dealkylation which is preferentially inducible by 3-methylcholanthrene. Drug Metab Dispos 2, 583-588.

Canivenc-Lavier, M. C., Bentejac, M., Miller, M. L., Leclerc, J., Siess, M. H., Latruffe, N., and Suschetet, M. (1996). Differential effects of nonhydroxylated flavonoids as inducers of cytochrome P450 1A and 2B isozymes in rat liver. Toxicol Appl Pharmacol 136, 348-353.

Chen, Y. H., Riby, J., Srivastava, P., Bartholomew, J., Denison, M., and Bjeldanes, L. (1995). Regulation of CYP1A1 by indolo[3,2-b]carbazole in murine hepatoma cells. J Biol Chem 270, 22548-22555.

Chen, Y. H., and Yang, D. (2002). Differential effects of vegetable-derived indoles on the induction of quinone reductase in hepatoma cells. J Nutr Sci Vitaminol (Tokyo) 48, 477-482.

Cook, P. W., Piepkorn, M., Clegg, C. H., Plowman, G. D., DeMay, J. M., Brown, J. R., and Pittelkow, M. R. (1997). Transgenic expression of the human amphiregulin gene induces a psoriasis-like phenotype. J Clin Invest 100, 2286-2294.

Dashwood, R. H. (1998). Indole-3-carbinol: anticarcinogen or tumor promoter in brassica vegetables? Chem Biol Interact 110, 1-5.

Denison, M. S., and Nagy, S. R. (2003). Activation of the aryl hydrocarbon receptor by structurally diverse exogenous and endogenous chemicals. Annu Rev Pharmacol Toxicol 43, 309-334.

Fernandez-Salguero, P. M., Hilbert, D. M., Rudikoff, S., Ward, J. M., and Gonzalez, F. J. (1996). Aryl-hydrocarbon receptor-deficient mice are resistant to 2,3,7,8-tetrachlorodibenzo-p-dioxin-induced toxicity. Toxicol Appl Pharmacol 140, 173-179.

Frueh, F. W., Hayashibara, K. C., Brown, P. O., and Whitlock, J. P., Jr. (2001). Use of cDNA microarrays to analyze dioxin-induced changes in human liver gene expression. Toxicol Lett 122, 189-203.

Hankinson, O. (1995). The aryl hydrocarbon receptor complex. Annu Rev Pharmacol Toxicol 35, 307-340.

Heijne, W. H., Stierum, R. H., Slijper, M., van Bladeren, P. J., and van Ommen, B. (2003). Toxicogenomics of bromobenzene hepatotoxicity: a combined transcriptomics and proteomics approach. Biochem Pharmacol 65, 857-875. 
Herrmann, S., Seidelin, M., Bisgaard, H. C., and Vang, O. (2002). Indolo[3,2-b]carbazole inhibits gap junctional intercellular communication in rat primary hepatocytes and acts as a potential tumor promoter. Carcinogenesis 23, 1861-1868.

Hoffer, A., Chang, C. Y., and Puga, A. (1996). Dioxin induces transcription of fos and jun genes by Ah receptordependent and -independent pathways. Toxicol Appl Pharmacol 141, 238-247.

Hoogenboom, L. A., Hamers, A. R., and Bovee, T. F. (1999). Bioassays for the detection of growth-promoting agents, veterinary drugs and environmental contaminants in food. Analyst 124, 79-85.

Hoogenboom, R. (2002). The combined use of the CALUX bioassay and the HRGC/HRMS method for the detection of novel dioxin sources and new dioxin-like compounds. Environ Sci Pollut Res Int 9, 304306.

Ilantzis, C., DeMarte, L., Screaton, R. A., and Stanners, C. P. (2002). Deregulated expression of the human tumor marker CEA and CEA family member CEACAM6 disrupts tissue architecture and blocks colonocyte differentiation. Neoplasia 4, 151-163.

JECFA (2002). Polychlorinated dibenzodioxins, polychlorinated dibenzofurans, and coplanar polychlorinated biphenyls. In: Canady, R., Crump, K., Feeley, M., Freijer, J., Kogevinas, M., Malisch, R., Verger, P., Wilson, J., Zeilmaker, M. (Eds.), Safety Evaluation of Certain Food Additives and Contaminants. Report of the 57th Meeting of the Joint FAO/WHO Expert Committee on Food Additives and Contaminants. WHO Food Additives Series, vol. 48. World Health Organization, Geneva, pp. 451-664.

Jeuken, A., Keser, B. J. G., Khan, E., Brouwer, A., Koeman, J., and Denison, M. S. (2003). Activation of the Ah receptor by extracts of dietary herbal supplements, vegetables, and fruits. Journal of Agricultural and Food Chemistry 51, 5478-5487.

Kall, M. A., Vang, O., and Clausen, J. (1996). Effects of dietary broccoli on human in vivo drug metabolizing enzymes: evaluation of caffeine, oestrone and chlorzoxazone metabolism. Carcinogenesis 17, 793-799.

Kizu, R., Okamura, K., Toriba, A., Kakishima, H., Mizokami, A., Burnstein, K. L., and Hayakawa, K. (2003). A role of aryl hydrocarbon receptor in the antiandrogenic effects of polycyclic aromatic hydrocarbons in LNCaP human prostate carcinoma cells. Arch Toxicol 77, 335-343.

Kleman, M. I., Poellinger, L., and Gustafsson, J. A. (1994). Regulation of human dioxin receptor function by indolocarbazoles, receptor ligands of dietary origin. J Biol Chem 269, 5137-5144.

Koenig, W. (2003). Fibrin(ogen) in cardiovascular disease: an update. Thromb Haemost 89, 601-609.

Liu, H., Wormke, M., Safe, S. H., and Bjeldanes, L. F. (1994). Indolo[3,2-b]carbazole: a dietary-derived factor that exhibits both antiestrogenic and estrogenic activity. J Natl Cancer Inst 86, 1758-1765.

Malhotra, S., Newman, E., Eisenberg, D., Scholes, J., Wieczorek, R., Mignatti, P., and Shamamian, P. (2002). Increased membrane type 1 matrix metalloproteinase expression from adenoma to colon cancer: a possible mechanism of neoplastic progression. Dis Colon Rectum 45, 537-543.

Martinez, J. M., Afshari, C. A., Bushel, P. R., Masuda, A., Takahashi, T., and Walker, N. J. (2002). Differential toxicogenomic responses to 2,3,7,8-tetrachlorodibenzo-p-dioxin in malignant and nonmalignant human airway epithelial cells. Toxicol Sci 69, 409-423.

Martinez, M. E., O’Brien, T. G., Fultz, K. E., Babbar, N., Yerushalmi, H., Qu, N., Guo, Y., Boorman, D., Einspahr, J., Alberts, D. S., and Gerner, E. W. (2003). Pronounced reduction in adenoma recurrence associated with aspirin use and a polymorphism in the ornithine decarboxylase gene. Proc Natl Acad Sci U S A 100, 7859-7864.

Maruyama, W., and Aoki, Y. (2006). Estimated cancer risk of dioxins to humans using a bioassay and physiologically based pharmacokinetic model. Toxicol Appl Pharmacol 214, 188-198.

Mimura, J., and Fujii-Kuriyama, Y. (2003). Functional role of AhR in the expression of toxic effects by TCDD. Biochimica Et Biophysica Acta-General Subjects 1619, 263-268.

Murphy, K. A., Villano, C. M., Dorn, R., and White, L. A. (2004). Interaction between the aryl hydrocarbon receptor and retinoic acid pathways increases matrix metalloproteinase-1 expression in keratinocytes. $J$ Biol Chem 279, 25284-25293.

Nebert, D. W., Roe, A. L., Dieter, M. Z., Solis, W. A., Yang, Y., and Dalton, T. P. (2000). Role of the aromatic hydrocarbon receptor and [Ah] gene battery in the oxidative stress response, cell cycle control, and apoptosis. Biochem Pharmacol 59, 65-85.

Nur, T., Peijnenburg, A. A., Noteborn, H. P., Baykus, H., and Reifen, R. (2002). DNA microarray technology reveals similar gene expression patterns in rats with vitamin a deficiency and chemically induced colitis. J Nutr 132, 2131-2136. 
Park, J. Y., Shigenaga, M. K., and Ames, B. N. (1996). Induction of cytochrome P4501A1 by 2,3,7,8-tetrachlorodibenzo-p-dioxin or indolo(3,2-b)carbazole is associated with oxidative DNA damage. Proc Natl Acad Sci U S A 93, 2322-2327.

Pellis, L., Franssen-van Hal, N. L., Burema, J., and Keijer, J. (2003). The intraclass correlation coefficient applied for evaluation of data correction, labeling methods, and rectal biopsy sampling in DNA microarray experiments. Physiol Genomics 16, 99-106.

Pohjanvirta, R., Korkalainen, M., McGuire, J., Simanainen, U., Juvonen, R., Tuomisto, J. T., Unkila, M., Viluksela, M., Bergman, J., Poellinger, L., and Tuomisto, J. (2002). Comparison of acute toxicities of indolo[3,2-b] carbazole (ICZ) and 2,3,7,8-tetrachlorodibenzo-p-dioxin (TCDD) in TCDD-sensitive rats. Food Chem Toxicol 40, 1023-1032.

Pohjanvirta, R., Vartiainen, T., Uusi Rauva, A., Monkkonen, J., and Tuomisto, J. (1990). Tissue distribution, metabolism, and excretion of 14C-TCDD in a TCDD-susceptible and a TCDD-resistant rat strain. Pharmacol Toxicol 66, 93-100.

Puga, A., Maier, A., and Medvedovic, M. (2000). The transcriptional signature of dioxin in human hepatoma HepG2 cells. Biochem Pharmacol 60, 1129-1142.

Puga, A., Tomlinson, C. R., and Xia, Y. (2005). Ah receptor signals cross-talk with multiple developmental pathways. Biochem Pharmacol 69, 199-207.

Radford, D. M., Nakai, H., Eddy, R. L., Haley, L. L., Byers, M. G., Henry, W. M., Lawrence, D. D., Porter, C. W., and Shows, T. B. (1990). Two chromosomal locations for human ornithine decarboxylase gene sequences and elevated expression in colorectal neoplasia. Cancer Res 50, 6146-6153.

Safe, S., Qin, C., and McDougal, A. (1999). Development of selective aryl hydrocarbon receptor modulators for treatment of breast cancer. Expert Opin Investig Drugs 8, 1385-1396.

Safe, S., and Wormke, M. (2003). Inhibitory aryl hydrocarbon receptor-estrogen receptor alpha cross-talk and mechanisms of action. Chem Res Toxicol 16, 807-816.

Safe, S., Wormke, M., and Samudio, I. (2000). Mechanisms of inhibitory aryl hydrocarbon receptor-estrogen receptor crosstalk in human breast cancer cells. J Mammary Gland Biol Neoplasia 5, 295-306.

Sarkar, F. H., and Li, Y. (2004). Cell signaling pathways altered by natural chemopreventive agents. Mutation Research/Fundamental and Molecular Mechanisms of Mutagenesis 555, 53-64.

Sepkovic, D. W., Bradlow, H. L., and Bell, M. (2001). Quantitative determination of 3,3'-diindolylmethane in urine of individuals receiving indole-3-carbinol. Nutr Cancer 41, 57-63.

Sherratt, P. J., McLellan, L. I., and Hayes, J. D. (2003). Positive and negative regulation of prostaglandin E2 biosynthesis in human colorectal carcinoma cells by cancer chemopreventive agents. Biochem Pharmacol 66, 51-61.

Shoyab, M., Plowman, G. D., McDonald, V. L., Bradley, J. G., and Todaro, G. J. (1989). Structure and function of human amphiregulin: a member of the epidermal growth factor family. Science 243, 1074-1076.

Spencer, D. L., Masten, S. A., Lanier, K. M., Yang, X., Grassman, J. A., Miller, C. R., Sutter, T. R., Lucier, G. W., and Walker, N. J. (1999). Quantitative analysis of constitutive and 2,3,7,8-tetrachlorodibenzo-p-dioxininduced cytochrome P450 1B1 expression in human lymphocytes. Cancer Epidemiol Biomarkers Prev 8, 139-146.

Steenland, K., Bertazzi, P., Baccarelli, A., and Kogevinas, M. (2004). Dioxin revisited: developments since the 1997 IARC classification of dioxin as a human carcinogen. Environ Health Perspect 112, 1265-1268.

Wang, X., Harris, P. K., Ulrich, R. G., and Voorman, R. L. (1996). Identification of dioxin-responsive genes in Hep G2 cells using differential mRNA display RT-PCR. Biochem Biophys Res Commun 220, 784-788.

Wen, Y. H., Sahi, J., Urda, E., Kulkarni, S., Rose, K., Zheng, X., Sinclair, J. F., Cai, H., Strom, S. C., and Kostrubsky, V. E. (2002). Effects of bergamottin on human and monkey drug-metabolizing enzymes in primary cultured hepatocytes. Drug Metab Dispos 30, 977-984.

Yoshida, M., Katashima, S., Ando, J., Tanaka, T., Uematsu, F., Nakae, D., and Maekawa, A. (2004). Dietary indole3-carbinol promotes endometrial adenocarcinoma development in rats initiated with N-ethyl-N'-nitro$\mathrm{N}$-nitrosoguanidine, with induction of cytochrome P450s in the liver and consequent modulation of estrogen metabolism. Carcinogenesis 25, 2257-2264.

Zeligs, M. A. (2002). DIM and I3C: The real facts on safety. www.dimfaq.com/site/I3C-safety.htm.

Zhang, W., Mi, J., Li, N., Sui, L., Wan, T., Zhang, J., Chen, T., and Cao, X. (2001). Identification and characterization of DPZF, a novel human BTB/POZ zinc finger protein sharing homology to BCL-6. Biochem Biophys Res Commun 282, 1067-1073. 



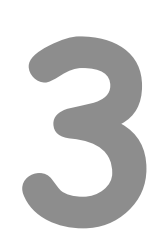

\title{
Ah receptor agonist activity in frequently consumed food items
}

\author{
Pim W.J. de Waard ${ }^{a}$, Jac M.M.J.G. Aarts ${ }^{\text {b }}$, Ad A.C.M. Peijnenburg ${ }^{c}$, \\ Theo M.C.M. de Kok ${ }^{a}$, Frederik-Jan van Schooten ${ }^{a}$, \\ Ron L.A.P. Hoogenboom ${ }^{c}$
}

${ }^{a}$ Department of Health Risk Analysis and Toxicology, Maastricht University, PO box 616, 6200 MD Maastricht, The Netherlands; ${ }^{b}$ Division of Toxicology, Wageningen University, PO box 8000, 6700 EA Wageningen, The Netherlands, ' RIKILT Institute of Food Safety, PO box 230, 6700 EA Wageningen, The Netherlands 


\section{Abstract}

The aryl hydrocarbon receptor (AhR) receives much attention for its role in the toxicity of dioxins and dioxin-like PCBs. However, also many other compounds have been reported to bind and activate the AhR, of which natural food components are of special interest from a human health perspective. Using the DR CALUX bioassay, we screened extracts from many food items, frequently consumed in The Netherlands, to estimate the intake of natural AhR-agonists (NAhRAs). Using the prototypical AhR-agonist TCDD as standard, we estimated that the daily intake of NAhRAs may be considerably higher than the reported intake of dioxins and dioxin-like PCBs. Potatoes, cruciferous vegetables, bread, hamburgers and grapefruit juice contained most NAhRAs. Food preparation and acid treatment can show a significant effect on the AhR-activation. Interaction of natural and xenobiotic AhR-agonists should be taken into account when performing risk-benefit analysis of both types of compounds.
\end{abstract}




\section{INTRODUCTION}

The aryl hydrocarbon receptor (AhR) is a cytosolic ligand-activated transcription factor, which is present in many cell types of mammals, including humans. At the moment, there is still no consensus about the biological function of this receptor. However, it received much attention for its role in the toxicity of dioxins, especially the most potent activator 2,3,7,8-tetrachlorodibenzo- $p$ dioxin (TCDD) (Hankinson 1995; Safe 2001).

Not only contaminants like dioxins, PCBs and PAHs can bind to the AhR, but also a large number of compounds of natural origin can bind to and activate this receptor. Surprisingly, these compounds can have very different chemical structures, which indicates that this receptor has a rather promiscuous ligand binding site (Denison and Nagy 2003; Safe 1998). One of the most investigated natural AhR agonists (NAhRAs) is indole-3-carbinol (I3C), which is formed in cruciferous vegetables (Brussels sprouts, broccoli, cabbage) by an enzymatic reaction after crushing of the plant tissues. During consumption, I3C undergoes self-condensation into a number of oligomers and indolo[3,2-b]carbazole (ICZ) in the acid environment of the stomach. Although ICZ is formed in very low amounts (ca $0.0002 \%$ ), its AhR activating potency is relatively high (Bjeldanes and others 1991). Also many other food items have been shown to contain relatively large amounts of NAhRAs, of which the chemical identity of the receptor-activating compounds is often unknown (Jeuken and others 2003).

In contrast with the prototypical AhR agonist TCDD and related toxic compounds, the NAhRAs do apparently not show clear toxic effects at normal dietary exposure levels; on the contrary, they even seem to have beneficial health effects. Many researchers attribute this to the induction of a number of phase I and II detoxifying biotransformation enzymes, like the cytochrome P450s CYP1A1, CYP1A2, GSTP, and NQO1 (Kim and Milner 2005; Rogan 2006). However, these enzymes are induced by the activation of the AhR, and are thus also induced by TCDD and other toxic dioxinlike contaminants. A distinctive property of the NAhRAs seems to be their rapid clearance from the body, resulting in an essentially transient effect on the expression of AhR-regulated genes as compared to the more persistent xenobiotic AhR agonists (Chen and others 1995; Pohjanvirta and others 2002). Another property that seems to distinguish many NAhRAs from e.g. dioxins is their ability to inhibit the enzymatic function of P450 enzymes, and even to inhibit AhR activation by TCDD (Amakura and others 2002; Pohl and others 2006). This raises the question whether humans are exposed to such an amount of NAhRAs that they could inhibit the possible toxic effects of compounds like dioxins and PAHs or that they may present a risk hazard because of their AhR agonist activity.

The purpose of our study was to examine the AhR-activating properties of a number of food items frequently consumed in The Netherlands, in order to identify sources of NAhRAs and relate their intake by humans to that of dioxin-like AhR-activating food contaminants. We prepared the food samples in the way they are consumed normally by Dutch consumers, and we included treatment of the samples with hydrochloric acid $(\mathrm{HCl})$ to mimic the acid environment of the stomach. A low $\mathrm{pH}$ could theoretically hydrolyse unstable NAhRAs and deactivate them, but on the other hand, some 
natural compounds, like I3C, can be transformed by acidification into relatively strong AhR agonists such as ICZ. Comparing the AhR-activation by the NAhRAs, as measured with the DR CALUX assay, with the activity of TCDD, and relating this to the Dutch Food Consumption Survey of 2003 (Hulshof and others 2004), provided us with an estimation of the theoretical load of NAhRAs in the human diet. Because of the difficulty to measure every food item, this is likely to result in an underestimation of the actual intake.

\section{MATERIALS AND METHODS}

\section{Chemicals}

Methanol, n-hexane, diethyl ether, sulphuric acid and silica gel 60 (70-230 mesh) were purchased from Merck (Darmstadt, Germany), luciferin assay mixture from Promega (Madison, WI, USA), cyclohexane and ethylacetate from Biosolve (Valkenswaard, The Netherlands).

\section{Preparation of food extracts}

All food items were bought at local supermarkets. Solid foods were grinded by a food chopper T71 (Moulinex, Woerden, The Netherlands). Five gram of fresh solid food or $10 \mathrm{ml}$ of liquid food was mixed with $20 \mathrm{ml}$ of methanol/water 85/15, and after $30 \mathrm{~min}$ of soaking, extracted twice with $20 \mathrm{ml}$ of $\mathrm{n}$-hexane/diethyl ether $97 / 3$ by mixing for $1 \mathrm{~h}$ in an overhead mixer (REAX 2, Heidolph, Germany), followed by centrifugation at $3000 \mathrm{rpm}$ for $10 \mathrm{~min}$. Hexane-layers were collected, evaporated in a Speedvac (Hetavac VR-1, Birkerod, Denmark) and the residue dissolved in $40 \mu \mathrm{l}$ of DMSO (Merck, Darmstadt, Germany). In order to mimic the acid environment of the stomach, in addition grinded samples were 1:1 mixed with $0.1 \mathrm{M} \mathrm{HCl}$, adjusted to $\mathrm{pH}=1$ with $1 \mathrm{M} \mathrm{HCl}$ (Merck, Darmstadt, Germany), and mixed for an hour before addition of the methanol/water. When relevant, samples were boiled before grinding according to common Dutch kitchen practises, and afterwards, also the boiling water was collected for examination. Extracts from food samples containing fat, like bread and meat, were defatted in order to prevent incomplete mixing with the medium. Extract residues containing $40 \mu \mathrm{l}$ DMSO were dissolved in $15 \mathrm{ml}$ of eluent (cyclohexane/ethylacetate $1 / 1 \mathrm{v} / \mathrm{v}$ ), of which $12.5 \mathrm{ml}$ were inserted into a gel permeation chromatography system (Gilson). Fat was separated by a BioBeads SX3 column (i.d. $2.5 \mathrm{~cm}$, length $60 \mathrm{~cm}, 200-400 \mathrm{mesh}$ ), and the eluted fraction from 44 to 107 min was collected and evaporated until $40 \mu \mathrm{L}$ DSSO. To check for contamination with dioxinlike persistent AhR agonists, hexane-extracts of a number of samples were transferred on a column containing $10 \mathrm{~g}$ acid silica $\left(33 \% \mathrm{H}_{2} \mathrm{SO}_{4}\right)$, on which NAhRAs are removed (Hoogenboom and others 2006b) and subsequently tested for residual AhR-agonist activity by DR CALUX analysis.

\section{Cell culture and treatment}

DR CALUX ${ }^{*}$ cells (rat H4IIE hepatoma cells stably transfected with pGudluc1.1, an AhR-regulated luciferase reporter plasmid) (Aarts and others 1995) were grown in a-MEM (Sigma, St-Louis, USA), containing 10\% fetal bovine serum (GIBCO, Breda, The Netherlands) and $1 \%$ penicillin/ streptomycin (Sigma), at $37^{\circ} \mathrm{C}$ and $5 \% \mathrm{CO}_{2}$. Cells were seeded $24 \mathrm{~h}$ before exposure in Costar 48 
well-plates $\left(5.10^{4}\right.$ cells/well $)$ and exposed for $24 \mathrm{~h}$ to sample solutions in DMSO added to the culture medium. During each experiment, a calibration curve was made of 0.5-500 pM TCDD (Schmidt BV, Amsterdam, The Netherlands). The undiluted sample concentration of the solid foods was equivalent to $1250 \mathrm{mg}$ fresh product per ml exposure medium, except for the meat samples and fish, of which the concentration was $625 \mathrm{mg} / \mathrm{ml}$. The undiluted concentration of the liquid samples was $2500 \mathrm{mg} / \mathrm{ml}$. Samples were also diluted 3, 9, 27 or 81 times. The final concentration of DMSO in all exposures was $1.0 \%(\mathrm{~V} / \mathrm{V})$. In addition, a number of samples were also exposed for 4, 8 and $16 \mathrm{~h}$.

\section{DR CALUX assay}

The Dioxin Receptor - Chemical-Activated LUciferase gene eXpression assay was performed as described previously (Bovee and others 1998). After exposure of the cells in 48 -well microtiter plates the medium was removed and cells were washed with PBS. Cells were lysed using Cell Culture Lysis Reagent (Promega), centrifuged and $20 \mu$ of lysed solution of each well was transferred to a 96 wells plate. Luminescence was measured with a LuminoskanAscent (Thermo Labsystems, Finland) upon addition of $0.1 \mathrm{ml}$ of luciferin assay mixture $\left(20 \mathrm{mM}\right.$ Tricine, $1.07 \mathrm{mM}\left(\mathrm{MgCO}_{3}\right)_{4} \mathrm{Mg}(\mathrm{OH})_{2} \cdot 5 \mathrm{H}_{2} \mathrm{O}$, $2.67 \mathrm{mM} \mathrm{MgSO}_{4} \cdot 7 \mathrm{H}_{2} \mathrm{O}, 0.1 \mathrm{mM}$ EDTA, $33.3 \mathrm{mM}$ DTT, $261 \mu \mathrm{M}$ Coenzyme A, $470 \mu \mathrm{M}$ Luciferin, 530 $\mu \mathrm{M}$ ATP, $\mathrm{pH} 7.8)$. Using the program SlideWrite $V 6$, the curve $y=a 0 /\left(1+(\mathrm{x} / \mathrm{a} 1)^{\wedge} \mathrm{a} 2\right)$, which describes the AhR activation process suitably (Hoogenboom and others 2006a) was fitted for the data and the response maximum of TCDD and the TCDD luciferase induction equivalents (TCDD-IEQs) of the food extracts were calculated.

\section{Statistics}

Statistical analyses were performed by use of the 2-side Student's t-test. Effects of acidification or boiling of groups of foods were tested paired.

\section{Results}

By use of the DR CALUX" bioassay, the Ah-receptor activity was measured in extracts from a number of food items, regularly consumed in The Netherlands. To rule out the effects of possible contamination with dioxins and other persistent AhR agonists, a number of samples with relatively high luciferase induction has been examined by use of the acid silica clean up procedure which destroys the more labile natural AhR agonists. None of the acid silica treated samples showed a significant induction of the luciferase reporter gene expression, except for the flatfish, which showed a CALUX activity of about one-third of the non acid silica treated sample (results not shown). To establish whether the food extracts showed a similarly persistent response as TCDD, the CALUX cells were also exposed for 4,8 and $16 \mathrm{~h}$ to a number of samples. Most of the samples induced luciferase 20-70 times more during $4 \mathrm{~h}$ and $8 \mathrm{~h}$, than during $24 \mathrm{~h}$ of exposure, both at the 3 (Figure 1) and 27 times dilutions (results not shown). The $16 \mathrm{~h}$ exposures showed less difference with $24 \mathrm{~h}$ (1-3 times). Apparently, the AhR agonists in all samples are less persistent in activity than TCDD, probably because of their faster metabolism or faster increase in response compared with TCDD. 


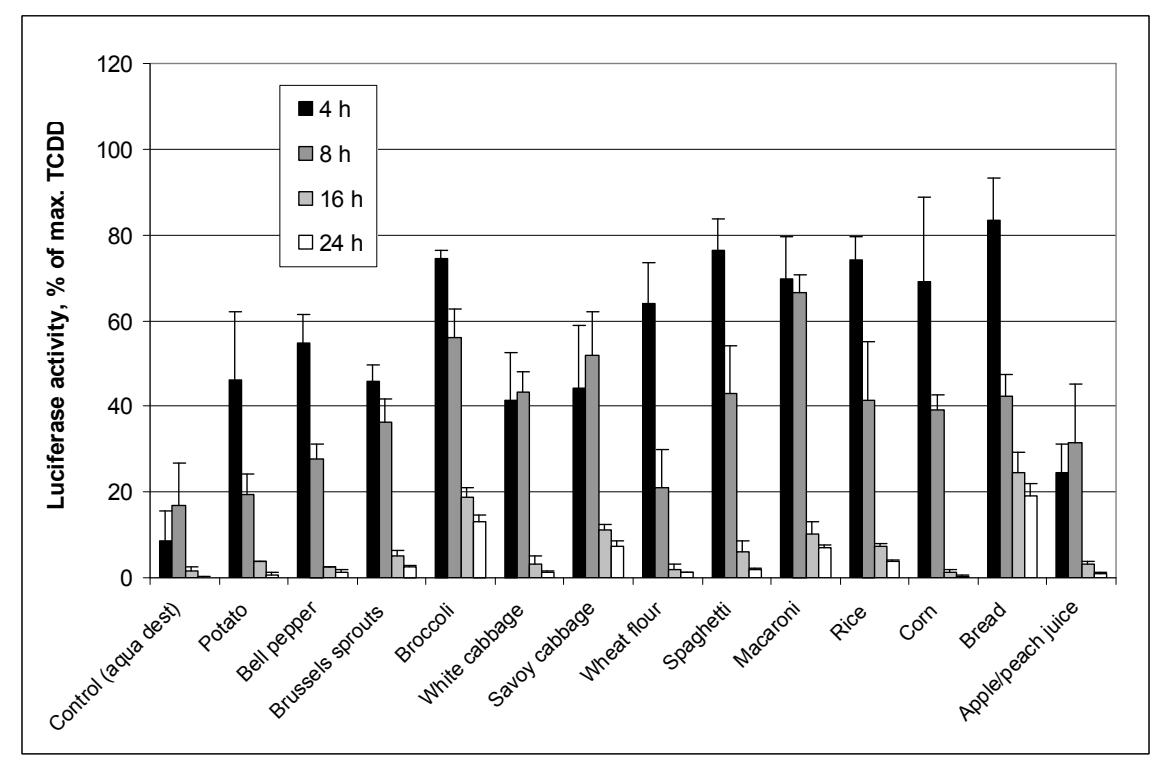

Fig. 1. Luciferase induction in rat H4IIEpGudluc1.1 cells determined by the DR CALUX ${ }^{\circledast}$ assay, expressed as \% of the maximum induction by TCDD after 4, 8, 16 and $24 \mathrm{~h}$ of exposure to 3 times diluted extracts of a number of frequently consumed food items. Bars: mean of triplicate exposures $\pm \mathrm{sd}$.

\section{DR CALUX $X^{\oplus}$ response in food items}

Figure 2 to 6 show the AhR activity in extracts of a number of food items frequently consumed in the Netherlands, as measured by the DR CALUX assay after $24 \mathrm{~h}$ of exposure. All samples were tested in dilution ranges, but for clarity reasons not all dilutions are shown. The influence of acidification has been determined for most of the food samples, and where relevant according to the habitual Dutch food preparation, also the effect of boiling has been studied. The results are reviewed in the same order of product groups as described in the Dutch Food Consumption Survey of 2003 (Hulshof and others 2004). The limit of detection of the used DR CALUX assay is 0.5 pM TCDD (Hoogenboom and others 2006a), which corresponds with a luciferase induction of about $1 \%$ of the maximum induction caused by TCDD. In this study, a luciferase induction of $2 \%$ is assumed to be a significant activation of the AhR, corresponding to a limit of quantitation (LOQ) of $0.1 \mathrm{pg}$ TCDD-luciferase induction equivalents (TCDD-IEQ) per gram of undiluted sample. After boiling the vegetables, the boiling water was collected and also examined for AhR activation, but the luciferase induction by these water extracts was negligible.

Potatoes. French fries contained a considerable amount of inducing compounds (up to $28 \%$ induction, Figure 2). At three dilutions, the acidification reduced the luciferase activity significantly by $20-30 \%$. Potatoes showed a significant luciferase activity of about $4-7 \%$ of the TCDD maximum at the highest concentration. Boiled potatoes showed significant less induction than acidified raw potatoes (Figure 3). 


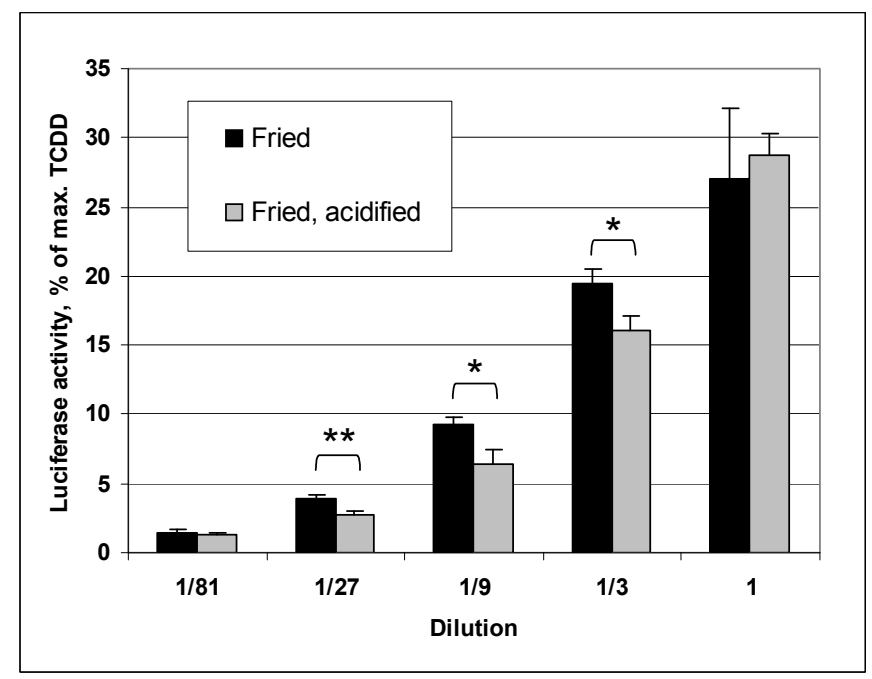

Fig. 2. DR CALUX ${ }^{\circledast}$ response in a dilution range of fried (black) and fried plus acidified (grey) French fries extracts. The exposure time was $24 \mathrm{~h}$. Bars: mean of triplicate exposures $\pm \mathrm{sd},{ }^{\star} \mathrm{P}<0.05,{ }^{\star *} \mathrm{P}<0.01$

Lettuce, carrot and pea. The DR CALUX" response of these vegetables was near or below $1 \%$ of TCDD maximum at the highest concentration (results not shown).

Bell pepper. Three different color types of bell pepper were examined. Undiluted samples showed an activity of 4-6\% of TCDD maximum. Acidification of the boiled vegetables increased the activity significantly (Figure 3).

Cruciferous vegetables. Four types of cruciferous vegetables have been examined: Brussels sprouts, broccoli, Savoy cabbage and white cabbage. All of them showed a relatively strong luciferase induction. Although Brussels sprouts tended to be the most strongly activating vegetable, the differences were not significant and the mean of all types has been plotted in Figure 3. As expected in view of the known acid induced NAhRAs like I3C in cruciferous vegetables, acidification increased the response significantly by 2.8 (acified vs raw) to 2 (boiled and acidified vs raw) times. Boiling did not have a large effect on luciferase induction.

Paste, rice and corn. Penne, macaroni, spaghetti and rice but not corn could induce the DR CALUX response by $2-7 \%$. Acidification increased the response of penne, and decreased the response of rice significantly (Figure 4).

Bread. Bread showed a significant response of $15-20 \%$ at the highest concentration (Figure 4). Acidification decreased the response, but not significantly. Wheat flour was very low in AhR activity (results not shown).

Meat and fish. Very high levels of AhR activity, up to 80\% of the TCDD maximum, were observed with hamburgers and the flatfish plaice, and to a lesser extent with fried minced beef (Figure 5). Raw minced beef showed no significant response and frying also increased the response of chicken breast and hamburger, but decreased the response of steak significantly. Acidification of the fried samples had no significant influence on the luciferase induction. 


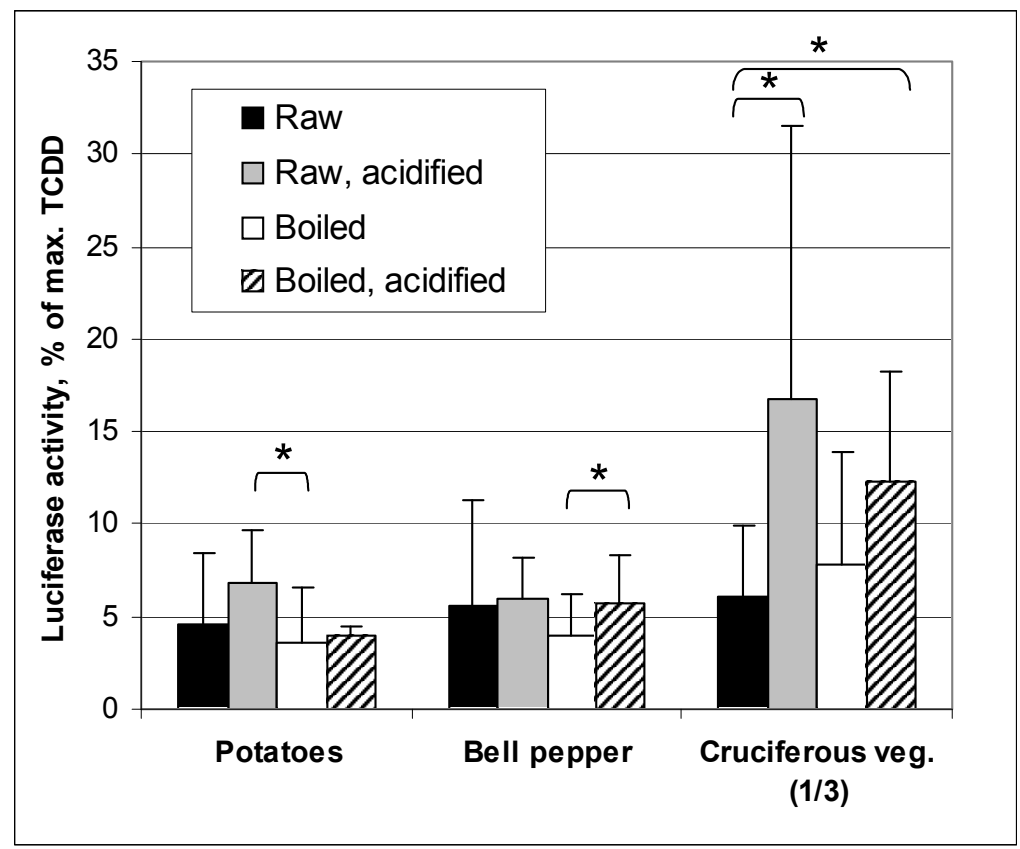

Fig. 3. DR CALUX ${ }^{\star}$ response in extracts of raw (black), raw plus acidified (grey), boiled (white) and boiled plus acidified (striped) potatoes, bell pepper and cruciferous vegetables. The exposure time was 24h. Bars: mean of four (potatoes, undiluted), three (bell pepper, undiluted, three different color types), or eleven (cruciferous vegetables, three times diluted, four different types) samples of vegetables $\pm \mathrm{sd},{ }^{*} \mathrm{P}<0.05$

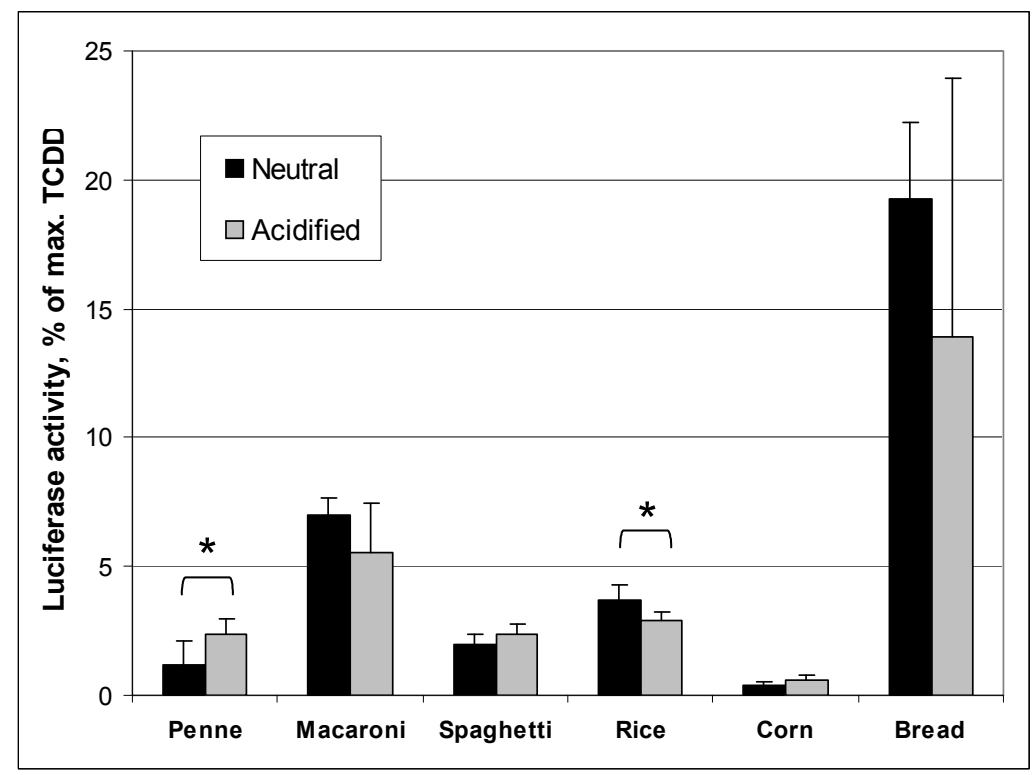

Fig. 4. DR CALUX ${ }^{\circledast}$ response in three times diluted extracts of boiled (black) and boiled plus acidified (grey) pastas, rice, corn and bread. The exposure time was $24 \mathrm{~h}$. Bars: mean of triplicate exposures $\pm \mathrm{sd},{ }^{*} \mathrm{P}<0.05$ 


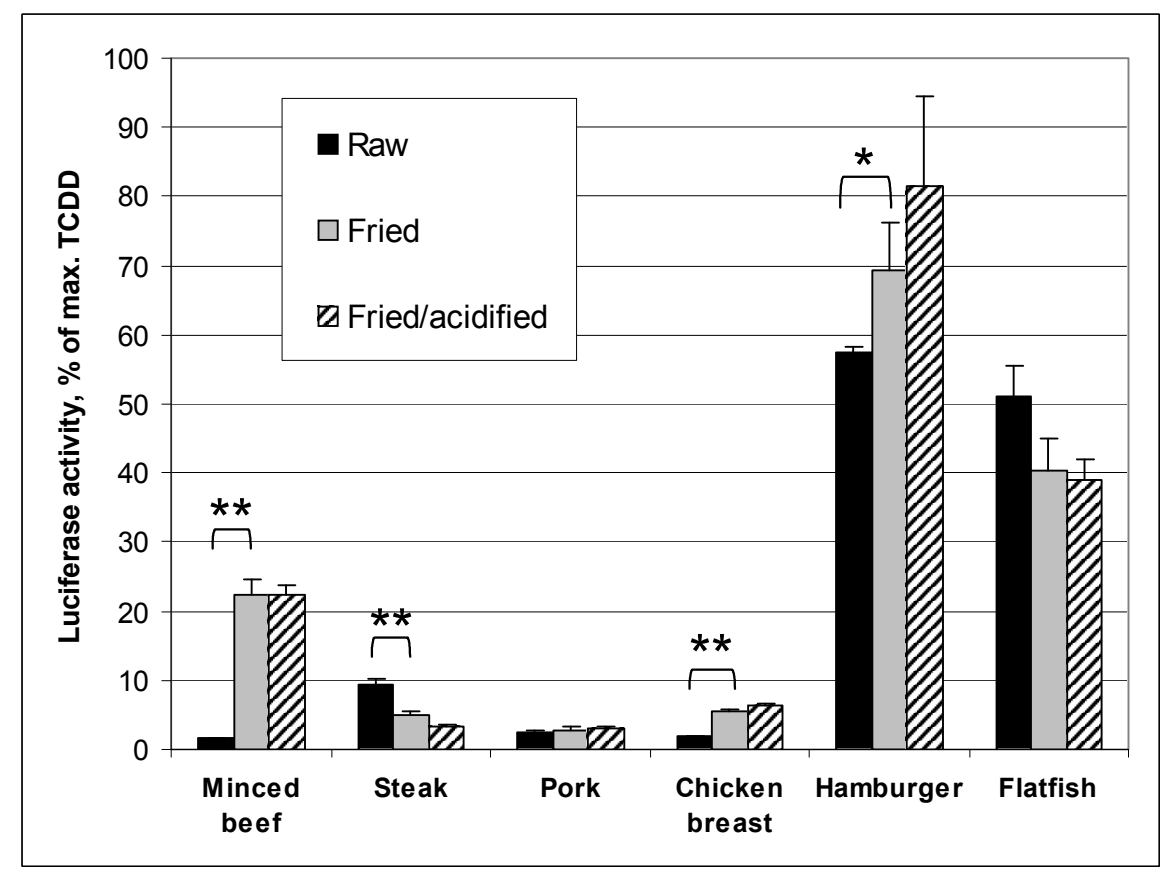

Fig. 5. DR CALUX ${ }^{\varpi}$ response of undiluted extracts of raw (black), fried (grey) and fried plus acidified (striped) samples from minced beaf, steak, pork, chicken breast, hamburger and flatfish (plaice). The exposure time was 24h. Bars: mean of triplicate exposures $\pm \mathrm{sd},{ }^{*} \mathrm{P}<0.05,{ }^{* *} \mathrm{P}<0.01$

Fruit juices. Undiluted orange juice showed a moderate activity of up to $30 \%$ of the TCDD maximum, while grapefruit juice highly induced the luciferase activity up to ca. $40 \%$ at low concentrations (Figure 6). Undiluted samples of grapefruit juice extracts were clearly cytotoxic, and also the 3-times dilutions were less active. Acidification of these fruit juices had no significant effect on the AhR induction, probably also because of the low $\mathrm{pH}$ of the juices themselves $(\mathrm{pH}=3.2)$.

\section{Human exposure with NAhRAs}

To estimate the amount of AhR-activating substances found in the human diet, we calculated their contribution to the DR CALUX induction relative to the induction by TCDD, and expressed it as pg TCDD luciferase induction-equivalents (TCDD-IEQ, Table 1). In this way TCDD has been used as a normalization standard for AhR-activity as measured by DR CALUX, enabling comparison with AhR-agonist levels in food items reported in literature. We emphasize that this does not imply a comparison to TCDD-toxicity. It was decided to use only the $24 \mathrm{~h}$ exposure data. Because the slope of the dose-response curves varies considerably between food extracts and TCDD, lower and upper limits of the DR CALUX" inductions were determined over the range of food extract dilutions tested, and the means of the representatives of the product groups are compared with the mean daily consumptions of the food items as reported in the Dutch Food Consumption Survey of 2003 (Hulshof and others 2004). Where appropriate, only acidified and boiled samples were taken into 


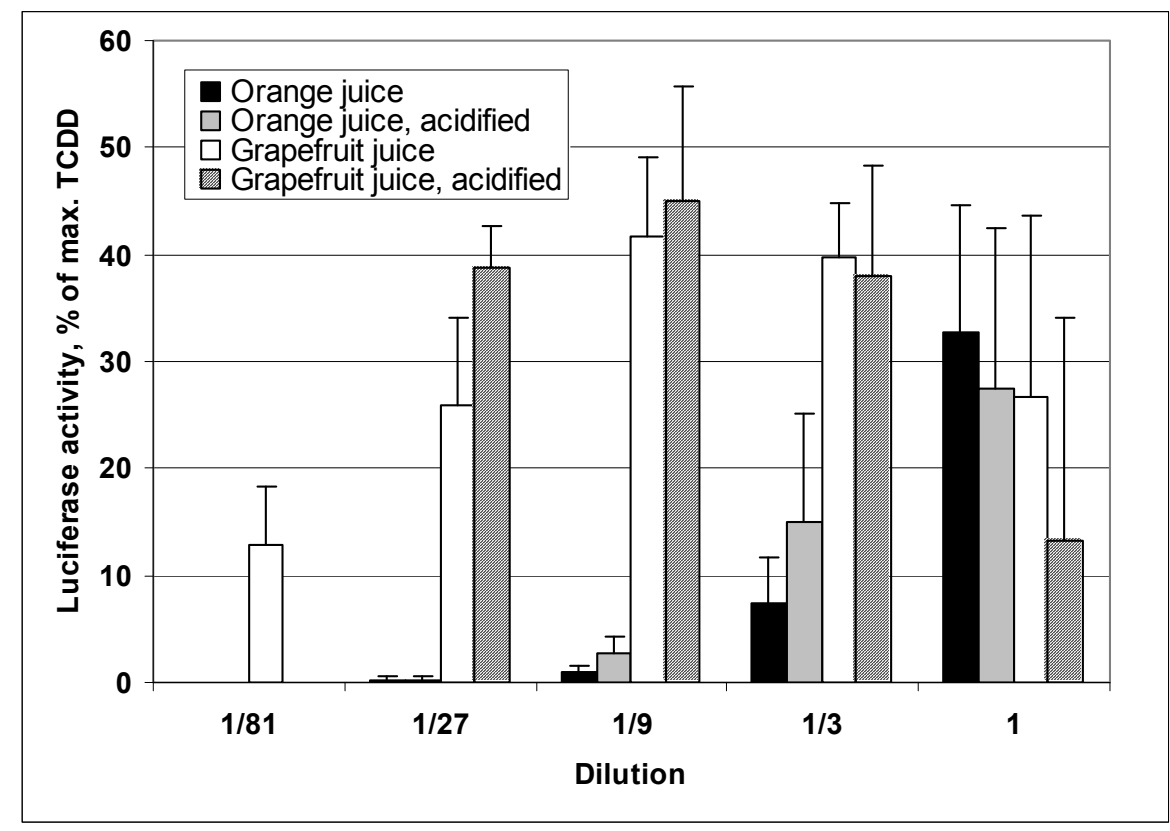

Fig. 6. DR CALUX ${ }^{\star}$ response in a dilution range of orange juice (black), acidified orange juice (grey), grapefruit juice (white) and acidified grapefruit juice (dark grey) extracts. The exposure time was 24h. Bars: mean of seven (orange juice) of three (grapefruit juice) different types $\pm \mathrm{sd}$. At the 81 times dilution only grapefruit juice has been measured.

account. Table 1 shows that the total TCDD-IEQ amounts to $1545 \mathrm{pg} /$ day at the lowest estimation, and $6235 \mathrm{pg} /$ day at the highest. Of all tested food extracts, potatoes, cruciferous vegetables, bread, hamburgers and fruit juices are the most important sources of AhR agonist activity for the average consumer. The 81-times diluted grapefruit juice extract showed the highest relative DR CALUX' activity of $41 \mathrm{pg}$ TCDD-IEQ per g of product (results not shown). Because of the relatively small sampling of food items in our study, the overall exposure of the Dutch people to these kind of bioactive compounds will probably be significantly higher.

\section{Discussion}

Many compounds of natural origin appear to be AhR-agonists and extracts of many food items were found to have a significant influence on the AhR activity as measured by in vitro and in vivo assays (Amakura and others 2002; Amakura and others 2003; Jeuken and others 2003; Leibelt and others 2003; Nishiumi and others 2006; Pohl and others 2006). Some of these compounds and mixtures showed both activating and inhibiting effects on the AhR pathway. Very high estimates of AhR activating potential by natural food components have been reported (Jeuken and others 2003; Safe 1998). However, a systematic inventory of the exposure of humans to NAhRAs in food has not been made. By analyzing a variety of food items frequently taken by Dutch consumers, and including the effect of food preparation and acidification, we showed in this study that the intake of 
Table 1. Estimated range of exposure of the Dutch population to NAhRAs from a number of frequently consumed food items, expressed as DR CALUX ${ }^{\circ}$ pg TCDD-IEQ/day. The food items are prepared according Dutch standards, and acidified to mimic the gastric environment. Levels based on the $24 \mathrm{~h}$ incubations of the DR CALUX bioassay.

\begin{tabular}{|c|c|c|c|c|c|c|}
\hline \multirow[t]{2}{*}{$\begin{array}{l}\text { VCP-2003 } \\
\text { Product group }\end{array}$} & \multirow[t]{2}{*}{ Samples } & \multirow{2}{*}{$\begin{array}{l}\text { VCP-2003 } \\
\text { Consumption } \\
\text { g/day }\end{array}$} & \multicolumn{2}{|c|}{$\begin{array}{l}\text { Range } \\
\text { pg TCDD-IEQ/g }\end{array}$} & \multicolumn{2}{|c|}{$\begin{array}{l}\text { Daily pg TCDD- } \\
\text { IEQ/day }\end{array}$} \\
\hline & & & Lower & Upper & Lower & Upper \\
\hline Potatoes & Mean of potatoes ${ }^{*}$ & 96 & 1.4 & 2.4 & 130 & 226 \\
\hline Leaf vegetables & Lettuce & 15 & 0.0 & 0.1 & $\mathbf{0}$ & 2 \\
\hline Fruit vegetables & Bell pepper ${ }^{*}$ & 28 & 0.2 & 0.9 & 6 & 25 \\
\hline Tuberous vegetables & Carrot $^{*}$ & 7 & 0.0 & 0.0 & $\mathbf{0}$ & $\mathbf{0}$ \\
\hline Crucifers & Mean of crucifers* & 23 & 1.8 & 4.5 & 40 & 103 \\
\hline Peas, beans & $\mathrm{Pea}^{*}$ & 3 & 0.0 & 0.0 & $\mathbf{0}$ & $\mathbf{0}$ \\
\hline Flour & Wheat flour & 1 & 0.8 & 0.8 & 1 & 1 \\
\hline Paste, rice & Mean of paste, rice ${ }^{*}$ & 46 & 0.7 & 0.7 & 31 & 32 \\
\hline Bread & Bread & 151 & 0.4 & 14.5 & 60 & 2190 \\
\hline Fresh meat & Mean of fresh meat & 44 & 0.8 & 1.1 & 36 & 47 \\
\hline Meat products & Hamburger ${ }^{*}$ & 60 & 10.5 & 24.9 & 630 & 1494 \\
\hline Fish & Plaice (flatfish) ${ }^{*}$ & 4 & 4.2 & 6.1 & 17 & 24 \\
\hline \multirow[t]{2}{*}{ Fruit juices } & Mean of fruit juices & 159 & 3.7 & 13.1 & 594 & 2088 \\
\hline & & & \multicolumn{2}{|c|}{ Total, pg/day } & 1545 & 6232 \\
\hline
\end{tabular}

* Samples boiled

* Samples fried

NAhRAs through the diet is probably not as high as previously thought (Jeuken and others 2003; Safe 1998), but still much higher than the intake of persistent xenobiotic AhR agonists (Baars and others 2004).

French fries, cruciferous vegetables, bread, hamburgers and citrus juices showed the most important AhR agonist activity of the food extracts we examined. Many natural compounds which can cause the AhR-activity in these food items may not have been identified yet. In cruciferous vegetables, the AhR agonists are attributed to the acid reaction products of indole-3-carbinol (I3C). In baked or fried foods, like fries, bread and meat products, the activity may be caused by compounds which originate from the formation of polycyclic aromatic hydrocarbons (PAHs), heterocyclic amines or Maillard products during the food preparation process at high temperatures. Also blood rests in meat may contribute to the AhR activity; heme degradation products like bilirubin and biliverdin are reported as AhR agonists. Polyphenols and furocoumarins are probably responsible for the shown activity in citrus fruit products (Denison and Nagy 2003).

Expressing the levels of NAhRAs in food in TCDD-IEQs may suggest that the responsible components represent a certain level of AhR-mediated toxicity according to the TEQ (toxic or dioxin equivalent) approach as described by Safe (Safe 1998). However, we emphasize that we only used TCDD-IEQs to compare AhR activity, because the NAhRAs do probably not meet some of the important requirements for the TEQ-principle, namely additivity, and more important, persistance 
(Safe 1998). However, TCDD is a very potent agonist, and shows very reproducible results in the DR-CALUX' assay, which makes it an ideal standard for the expression of relative AhR agonist activity. This implies that our results can not be interpreted as direct measurements of toxicity of food components, but only reveal the AhR activation effects, expressed as TCDD-IEQs or luciferase induction equivalents. Because the slopes of the dose-response curve of NAhRAs and PAHs differ from that of dioxins, the dilution of the samples has an important effect on the results of the calculation of pg TCDD-IEQs/g sample (Windal and others 2005). Because of the probably fragile nature of many natural compounds, it is important to include effects like food preparation and the effect of acidification in the gastric environment on the levels of AhR agonist activity. Frying and acidification can have a significant influence on AhR activity, boiling to a much lesser extent and the loss of AhR agonists in the boiling water was negligible.

The exposure time is another important factor in AhR activity measurement. Natural compounds, but also some PAHs like benzo[ $a$ ] pyrene, can be metabolized very quickly in comparison with TCDD (Chen and others 1995; Machala and others 2001; Pohjanvirta and others 2002). In our study, the luciferase induction after $4 \mathrm{~h}$ exposure to TCDD has reached only about $30 \%$ of its maximum after 24 $\mathrm{h}$, whereas the induction by PAHs and NAhRAs is higher at $4 \mathrm{~h}$ than at $24 \mathrm{~h}$ of exposure. As a result, a relatively short exposure time of $4 \mathrm{~h}$ will show a much higher luciferase induction by NAhRAs and PAHs compared with TCDD, than after $24 \mathrm{~h}$ of exposure. This may explain the large difference between some results of Jeuken et al. (2003) and ours. They found e.g. 640 pg TCDD-IEQ/g in potato, where we found 1.4-2.4 pg TCDD-IEQ/g (Table 1). However, based on our measurement with the $4 \mathrm{~h}$ exposure time, we found in line with Jeuken et al. a much higher amount of 110-332 pg TCDD-IEQ/g in potato. The interpretation of DR-CALUX measurements on extracts of food items is thus very complicated, and we do not pretend to give a conclusive opinion about their eventual toxic potential in the human diet. Important, however, is to obtain an estimation which shows whether the exposure to NAhRAs is considerably higher than to xenobiotic AhR agonists such as dioxins and other persistent compounds in the human diet, or much lower and negligible. In 1999, the estimated intake of the sum of dioxins and dioxin-like PCBs in The Netherlands was $1.2 \mathrm{pg}$ WHO-TEQ per kg body weight (bw) per day, which would be for a person weighing $70 \mathrm{~kg}$ $84 \mathrm{pg}$ WHO-TEQ. Of this population was $8 \%$ exposed to intake levels above the tolerable weekly intake for dioxins and dioxin-like PCBs of $14 \mathrm{pg}$ WHO-TEQ per kg bw per week, or over $140 \mathrm{pg}$ WHO-TEQ per person per day. The average dietary intake of these xenobiotic AhR agonists in 1978 was nearly 700 pg WHO-TEQ per person per day (Baars and others 2004). These levels are that far below the theoretical levels estimated by Jeuken et al. (e.g. 96000 pg TCDD-IEQ per serving of 150 g potato), or our study (1545-6235 pg TCDD-IEQ/day for part of the average daily diet), that the regular intake of NAhRAs should be seriously evaluated with regard to the biological meaning of the level of AhR activation that they may cause. On the one hand, the omnipresence of the competing natural AhR agonists, together with the presence of many AhR antagonists (Amakura and others 2002; Amakura and others 2003; Baumgart and others 2005) in food, may appear as a prophylaxis against xenobiotic intoxication via the AhR. On the other hand, several human studies showed 
AhR responsive effects, like CYP1A2 induction, by several non-dioxin like AhR agonists such as NAhRAs from cruciferous vegetables (Kall and others 1996; Murray and others 2001), I3C (Reed and others 2005), the anti-ulcer drug omeprazole (Rost and others 1992), and heterocyclic aromatic amines (Sinha and others 1994). This seems to be in contrast with a regular exposure to numerous AhR agonists in the human diet, which would constantly elevate the AhR activity. Another major problem in this is, that the exact pathways by which the xenobiotic dioxins and dioxin-like PCBs exert their toxicity are not well understood (Guzelian and others 2006; Steenland and others 2004). This makes it very difficult to understand to what extent NAhRAs, in amounts effective to cause AhR related effects, e.g. CYP1A2 induction by concentrated food additives, also can initiate dioxin-like toxic pathways, especially when slow processes like tumor promotion are involved. Besides tumor suppressing capacity, high doses of NAhRAs given to laboratory animals have sometimes also shown tumor promoting capacity (Dashwood 1998), and the accumulation effect of persistent fat-soluble xenobiotic AhR agonists could be mimicked by constant or regular NAhRA exposure.

In conclusion, this study confirms to a certain extent that the human diet contains a large amount of AhR-activating substances of natural origin, which triggers questions about the potential effects in humans, also in relation to the intake and adverse effects of xenobiotic dioxins and dioxin-like PCBs. In order to elucidate the potential toxicity or health-beneficial properties of these relatively large amounts of bioactive dietary components, the toxic pathway(s) of dioxins in humans should be elucidated first. This would give indications at what critical steps of the toxic pathway(s) the NAhRAs would have a significant dioxin-like toxic effect or on the contrary, induce totally different or even beneficial health effects, and what ultimately the predominant effect or the balance of all these effects would be.

\section{ACKNOWLEDgEMENT}

The authors thank Kyoko Sato, Liza Portier, Karin van Ede and Cornelis van de Kraats kindly for their important contribution to the sample treatment and the DR CALUX analysis. The Dutch Centre of Human Nutrigenomics (CHN) supported this study. 


\section{REFERENCES}

Aarts JM, Denison MS, Cox MA, Schalk MA, Garrison PM, Tullis K, de Haan LH, Brouwer A. 1995. Speciesspecific antagonism of Ah receptor action by 2,2',5,5'-tetrachloro- and 2,2',3,3'4,4'-hexachlorobiphenyl. Eur J Pharmacol 293(4):463-74.

Amakura Y, Tsutsumi T, Nakamura M, Kitagawa H, Fujino J, Sasaki K, Yoshida T, Toyoda M. 2002. Preliminary screening of the inhibitory effect of food extracts on activation of the aryl hydrocarbon receptor induced by 2,3,7,8-tetrachlorodibenzo-p-dioxin. Biol Pharm Bull 25(2):272-4.

Amakura Y, Tsutsumi T, Sasaki K, Yoshida T, Maitani T. 2003. Screening of the inhibitory effect of vegetable constituents on the aryl hydrocarbon receptor-mediated activity induced by 2,3,7,8-tetrachlorodibenzop-dioxin. Biol Pharm Bull 26(12):1754-60.

Baars AJ, Bakker MI, Baumann RA, Boon PE, Freijer JI, Hoogenboom LA, Hoogerbrugge R, van Klaveren JD, Liem AK, Traag WA and others. 2004. Dioxins, dioxin-like PCBs and non-dioxin-like PCBs in foodstuffs: occurrence and dietary intake in The Netherlands. Toxicol Lett 151(1):51-61.

Baumgart A, Schmidt M, Schmitz HJ, Schrenk D. 2005. Natural furocoumarins as inducers and inhibitors of cytochrome P450 1A1 in rat hepatocytes. Biochem Pharmacol 69(4):657-67.

Bjeldanes LF, Kim JY, Grose KR, Bartholomew JC, Bradfield CA. 1991. Aromatic hydrocarbon responsivenessreceptor agonists generated from indole-3-carbinol in vitro and in vivo: comparisons with 2,3,7,8-tetrachlorodibenzo-p-dioxin. Proc Natl Acad Sci U S A 88(21):9543-7.

Bovee TF, Hoogenboom LA, Hamers AR, Traag WA, Zuidema T, Aarts JM, Brouwer A, Kuiper HA. 1998. Validation and use of the CALUX-bioassay for the determination of dioxins and PCBs in bovine milk. Food Addit Contam 15(8):863-75.

Chen YH, Riby J, Srivastava P, Bartholomew J, Denison M, Bjeldanes L. 1995. Regulation of CYP1A1 by indolo[3,2-b]carbazole in murine hepatoma cells. J Biol Chem 270(38):22548-55.

Dashwood RH. 1998. Indole-3-carbinol: anticarcinogen or tumor promoter in brassica vegetables? Chem Biol Interact 110(1-2):1-5.

Denison MS, Nagy SR. 2003. Activation of the aryl hydrocarbon receptor by structurally diverse exogenous and endogenous chemicals. Annu Rev Pharmacol Toxicol 43:309-34.

Guzelian P, Quattrochi L, Karch N, Aylward L, Kaley R. 2006. Does dioxin exert toxic effects in humans at or near current background body levels?: An evidence-based conclusion. Hum Exp Toxicol 25(2):99-105.

Hankinson O. 1995. The aryl hydrocarbon receptor complex. Annu Rev Pharmacol Toxicol 35:307-40.

Hoogenboom L, Goeyens L, Carbonnelle S, van Loco J, Beernaert H, Baeyens W, Traag WA, Bovee TF, Jacobs G, Schoeters G. 2006a. The CALUX bioassay: Current status of its application to screening food and feed. Trends in Analytical Chemistry 25(4):410-420.

Hoogenboom R, Bovee T, Traag W, Hoogerbrugge R, Baumann B, Portier L, van de Weg G, de Vries J. 2006b. The use of the DR CALUX bioassay and indicator polychlorinated biphenyls for screening of elevated levels of dioxins and dioxin-like polychlorinated biphenyls in eel. Mol Nutr Food Res 50(10):945-57.

Hulshof KFAM, Ocke MC, van Rossum CTM, Buurma-Rethans EJM, Brants HAM, Drijvers JJMM, ter Doest D. 2004. Resultaten van de Voedselconsumptiepeiling 2003 (in Dutch). RIVM. Report nr 350030002/2004. 1-111 p.

Jeuken A, Keser BJG, Khan E, Brouwer A, Koeman J, Denison MS. 2003. Activation of the Ah receptor by extracts of dietary herbal supplements, vegetables, and fruits. Journal of Agricultural and Food Chemistry 51(18):5478-5487.

Kall MA, Vang O, Clausen J. 1996. Effects of dietary broccoli on human in vivo drug metabolizing enzymes: evaluation of caffeine, oestrone and chlorzoxazone metabolism. Carcinogenesis 17(4):793-9.

Kim YS, Milner JA. 2005. Targets for indole-3-carbinol in cancer prevention. J Nutr Biochem 16(2):65-73.

Leibelt DA, Hedstrom OR, Fischer KA, Pereira CB, Williams DE. 2003. Evaluation of chronic dietary exposure to indole-3-carbinol and absorption-enhanced 3,3'-diindolylmethane in sprague-dawley rats. Toxicol Sci 74(1):10-21.

Machala M, Vondracek J, Blaha L, Ciganek M, Neca JV. 2001. Aryl hydrocarbon receptor-mediated activity of mutagenic polycyclic aromatic hydrocarbons determined using in vitro reporter gene assay. Mutat Res 497(1-2):49-62.

Murray S, Lake BG, Gray S, Edwards AJ, Springall C, Bowey EA, Williamson G, Boobis AR, Gooderham NJ. 2001. Effect of cruciferous vegetable consumption on heterocyclic aromatic amine metabolism in man. Carcinogenesis 22(9):1413-20. 
Nishiumi S, Yabushita Y, Fukuda I, Mukai R, Yoshida K, Ashida H. 2006. Molokhia (Corchorus olitorius L.) extract suppresses transformation of the aryl hydrocarbon receptor induced by dioxins. Food Chem Toxicol 44(2):250-60.

Pohjanvirta R, Korkalainen M, McGuire J, Simanainen U, Juvonen R, Tuomisto JT, Unkila M, Viluksela M, Bergman J, Poellinger L and others. 2002. Comparison of acute toxicities of indolo[3,2-b]carbazole (ICZ) and 2,3,7,8-tetrachlorodibenzo-p-dioxin (TCDD) in TCDD-sensitive rats. Food Chem Toxicol 40(7):1023-32.

Pohl C, Will F, Dietrich H, Schrenk D. 2006. Cytochrome P450 1A1 expression and activity in Caco-2 cells: modulation by apple juice extract and certain apple polyphenols. J Agric Food Chem 54(26):10262-8.

Reed GA, Peterson KS, Smith HJ, Gray JC, Sullivan DK, Mayo MS, Crowell JA, Hurwitz A. 2005. A phase I study of indole-3-carbinol in women: tolerability and effects. Cancer Epidemiol Biomarkers Prev 14(8):195360.

Rogan EG. 2006. The natural chemopreventive compound indole-3-carbinol: state of the science. In Vivo 20(2):221-8.

Rost KL, Brosicke H, Brockmoller J, Scheffler M, Helge H, Roots I. 1992. Increase of cytochrome P450IA2 activity by omeprazole: evidence by the 13C-[N-3-methyl]-caffeine breath test in poor and extensive metabolizers of S-mephenytoin. Clin Pharmacol Ther 52(2):170-80.

Safe S. 2001. Molecular biology of the Ah receptor and its role in carcinogenesis. Toxicology Letters 120(1-3):17.

Safe SH. 1998. Development validation and problems with the toxic equivalency factor approach for risk assessment of dioxins and related compounds. J Anim Sci 76(1):134-41.

Sinha R, Rothman N, Brown ED, Mark SD, Hoover RN, Caporaso NE, Levander OA, Knize MG, Lang NP, Kadlubar FF. 1994. Pan-fried meat containing high levels of heterocyclic aromatic amines but low levels of polycyclic aromatic hydrocarbons induces cytochrome P4501A2 activity in humans. Cancer Res 54(23):6154-9.

Steenland K, Bertazzi P, Baccarelli A, Kogevinas M. 2004. Dioxin revisited: developments since the 1997 IARC classification of dioxin as a human carcinogen. Environ Health Perspect 112(13):1265-8.

Windal I, Denison MS, Birnbaum LS, Van Wouwe N, Baeyens W, Goeyens L. 2005. Chemically activated luciferase gene expression (CALUX) cell bioassay analysis for the estimation of dioxin-like activity: critical parameters of the CALUX procedure that impact assay results. Environ Sci Technol 39(19):735764. 



\title{
4
}

\section{A human intervention study with foods \\ containing natural Ah-receptor agonists does not significantly show AhR-mediated effects as measured in blood cells and urine}

\author{
Pim W.J. de Waard a, Ad A.C.M. Peijnenburg ', Hakan Baykus ${ }^{c}$, \\ Jac M.M.J.G. Aarts ${ }^{\text {d, }}$ Ron L.A.P. Hoogenboom ${ }^{\text {c }}$, Frederik-Jan van \\ Schooten ${ }^{\text {b }}$, Theo M.C.M. de Kok ${ }^{\text {b }}$
}

\footnotetext{
a Centre for Biological Medicines and Medical Technology, RIVM, PO box 1, 3720 BA Bilthoven, The Netherlands; ${ }^{\mathrm{b}}$ Department of Health Risk Analysis and Toxicology, Maastricht University, PO box 616, 6200 MD Maastricht, The Netherlands; ' Toxicology \& Effect Monitoring Group, RIKILT Institute of Food Safety, PO box 230, 6700 EA Wageningen, The Netherlands ${ }^{\mathrm{d}}$ Division of Toxicology, Wageningen University, PObox 8000, 6700 EA Wageningen, The Netherlands
} 


\section{Abstract}

Binding and activation of the aryl hydrocarbon receptor (AhR) is thought to be an essential step in the toxicity of the environmental pollutants dioxins and dioxin-like PCBs. However, also a number of natural compounds, referred to as NAhRAs (natural Ah-receptor agonists), which are present in e.g. fruits and vegetables, can bind and activate this receptor. To study their potencial effects in humans, we first investigated the effect of the prototypical AhR agonist 2,3,7,8-tetrachlorodibenzo$p$-dioxin (TCDD) on the gene expression in ex vivo exposed freshly isolated human lymphocytes, and compared the resulting gene expression profile with those caused by the well-known NAhRA indolo[3,2-b]carbazole (ICZ), originating from cruciferous vegetables, and by the hexane extract of NAhRA-containing grapefruit juice (GJE). TCDD and ICZ induced a similar gene expression profile in the lymphocytes, and both significantly up-regulated CYP1B1 and TIPARP (TCDD-inducible poly (ADP-ribose) polymerase) mRNA.

Next, we performed a human intervention study with NAhRA-containing cruciferous vegetables and grapefruit juice. The expression of the prototypical AhR responsive genes CYP1A1, CYP1B1 and NQO1 in whole blood cells and in freshly isolated lymphocytes was not significantly affected. Also enzyme activities of CYP1A2, CYP2A6, NAT2 and XO, as judged by caffeine metabolites in urine, were unaffected, except for a small down regulation of NAT2 activity by grapefruit juice. Examination of blood plasma with DR CALUX showed a $12 \%$ increased activity $3 \mathrm{~h}$ and $24 \mathrm{~h}$ after consumption of cruciferous vegetables, but did not show a significant effect of grapefruit juice consumption. We conclude that intake of NAhRAs from food may result in minor AhR-related effects measurable in human blood and urine.
\end{abstract}




\section{INTRODUCTION}

The aryl hydrocarbon receptor $(\mathrm{AhR})$ is a protein present in the cytoplasm of most human and other mammalian cells. Binding of the environmental contaminant and potent agonist 2,3,7,8-tetrachlorodibenzo- $p$-dioxin (TCDD) results in the translocation of the AhR to the nucleus of the cell, heterodimer formation with the AhR nuclear translocator (ARNT) and binding to dioxinresponsive elements in DNA. Transcription activation results in induction of the biotransformation enzymes CYP1A1, CYP1A2, CYP1B1, GSTP1, NQO1 and UDPGT1A6 (Hankinson, 1995; Nebert et al., 2000; Denison and Nagy, 2003). Activation of the AhR is thought to be the main trigger for the toxic effects of TCDD, such as tumor promotion, chloracne, immunosuppression, endometriosis, reduced sperm counts and teratogenesis (Fernandez-Salguero et al., 1996; Van den Berg et al., 1998; Mimura and Fujii-Kuriyama, 2003; Steenland et al., 2004).

Besides environmental contaminants like dioxins, dioxin-like PCBs and certain PAHs, also a number of natural ingredients in vegetables and fruit can bind to and activate the AhR. Examples of these compounds or mixtures are indolo[3,2-b]carbazole (ICZ), a gastric-acid reaction product of indole-3-carbinol (I3C), originating from cruciferous vegetables (Bergman et al., 2001), and the dye indigo and its by-product indirubin originating from plant fermentation (Sugihara et al., 2004). Also hexane extracts of citrus products and many other food items (Hoogenboom, 2002; Jeuken et al., 2003) show increased activity in the DR CALUX bioassay, a luciferase reporter-assay designed to detect the presence of AhR-agonists. In contrast to the toxic effects of TCDD, these natural AhR agonists (NAhRAs) in foods are often thought to have health promoting effects, like radical scavenging or tumor suppression (Broadbent and Broadbent, 1998; Yu et al., 2005). This is in agreement with many studies reporting beneficial effects of vegetables and fruit consumption (Steinmetz and Potter, 1996; Heber, 2004). Nevertheless, some animal experiments with I3C showed an increase in tumor formation after initiation with a carcinogen (Dashwood, 1998) and ICZ showed a TCDD-like inhibition of gap junction intercellular communication in vitro, indicative of a tumor promotive effect (Herrmann et al., 2002). Also epidemiological studies are inconsistent as to the overall healthy effects of foods containing NAhRAs or vegetables and fruit in general (Verhoeven et al., 1996; van Gils et al., 2005; Lynn et al., 2006). The growing market of dietary supplements, containing pure NAhRAs in very high concentrations compared to the foods of origin (Zeligs, 2002; Noonan and Noonan, 2006), makes it even more important to study this kind of compounds for possible unperceived health risks.

Because the mechanisms behind TCDD-toxicity are not well understood (Steenland et al., 2004), examination of the effect of AhR-activation on gene expression may serve as a first step in the elucidation of the molecular pathways involved (Heijne et al., 2005; Boverhof and Zacharewski, 2006). By using microarray technology, many dioxin-responsive genes in animal tissue and human cell lines have been determined after exposure to TCDD, and links with toxic properties of dioxins have been made (Puga et al., 2000; Frueh et al., 2001; Fletcher et al., 2005). Previously we compared the gene expression profiles in human Caco-2 colon cancer cells after exposure to ICZ or a grapefruit juice extract with those induced by TCDD and benzo[a]pyrene $(\mathrm{B}[\mathrm{a}] \mathrm{P})$. We found a remarkable 
resemblance between the gene expression profiles caused by xenobiotic and by natural AhR-agonists and many of the commonly expressed genes were related to cell proliferation and tumor promotion (De Waard et al., 2007). At the same time, it is likely that differences in kinetics and metabolism will change this picture in the intact organism.

In order to study the effects in vivo, the typical AhR responsive gene expression profile can possibly be used as a biomarker for AhR-activation. Since gene expression profiling in peripheral lymphocytes has been shown to be a promising approach to identify candidate biomarkers for AhR activation (Lampe et al., 2004; McHale et al., 2007), we first studied the effects on gene expression of TCDD and NAhRAs in ex vivo exposed human lymphocytes using microarrays. These cells were also exposed to the AhR antagonist $\alpha$-naphtoflavone (ANF) to check whether affected genes were AhR-regulated. Subsequently, the expression of some prototypical AhR-regulated genes was examined by RT-PCR in both human total blood cells and lymphocytes, obtained from volunteers consuming a NAhRAenriched diet, based on grapefruit juice and the cruciferous vegetables broccoli and Brussels sprouts. The effects of the diet intervention on blood plasma AhR agonist activity was measured by use of the DR CALUX' reporter gene bioassay, and on CYP1A2 enzyme activity by studying the metabolism of caffeine, which is a CYP1A2 substrate.

\section{Materials ANd Methods}

\section{Preparation of the grapefruit juice extract}

Ten $\mathrm{ml}$ of grapefruit juice, obtained from a local supermarket, was mixed with $20 \mathrm{ml}$ of methanol/ water $85 / 15$, and extracted twice with $20 \mathrm{ml}$ of $\mathrm{n}$-hexane/diethyl ether $97 / 3$ by mixing for $1 \mathrm{~h}$. Hexanelayers were collected, evaporated and the residue dissolved in $40 \mu \mathrm{l}$ of DMSO (Merck, Darmstadt, Germany) for analysis. Because the grapefruit juice extract (GJE) contains a mixture of compounds, the concentration is expressed as gram extracted sample per litre medium, used to expose the cells. Also a blank extraction of $10 \mathrm{ml}$ water has been performed (BLEX).

\section{Lymphocyte isolation}

Blood was sampled from volunteers and lymphocytes were isolated through gradient centrifugation using Lymphoprep in Leucosep filter tubes (Greiner Bio-One, Frickenhausen, Germany) according to the manufacturer's protocol. Cells were resuspended in RPMI 1640 medium, supplemented with $10 \%$ heat-inactivated fetal bovine serum, L-glutamine $(2 \mathrm{mM})$, and penicillin $100 \mathrm{U} / \mathrm{ml} /$ streptomycin $100 \mu \mathrm{g} / \mathrm{ml}$ at $1^{\star} 10^{6}$ cells $/ \mathrm{ml}$. No mitotic stimulation was applied to the quiescent cells.

\section{Cell exposures}

Freshly isolated lymphocytes were ex vivo exposed to solvent or $5 \mathrm{nM}$ TCDD (Schmidt BV, Amsterdam, The Netherlands) for 24 and $72 \mathrm{~h}$ for gene expression analysis. Chemicals and extracts were dissolved in DMSO, of which the final concentration was kept at $0.5 \%$ in the growth medium. Freshly isolated lymphocytes from volunteers for the microarray study were exposed ex vivo for 48 $\mathrm{h}$ to $500 \mathrm{pM}$ TCDD ( $\mathrm{n}=5), 100 \mathrm{nM}$ ICZ $(\mathrm{n}=4$, purity $>95 \%$, synthesized as described by Bergman 
(Bergman, 1970) and checked for quality by HPLC, NMR, IR and MS, and with a reference sample (A kind gift of prof. J. Bergman, Department of Chemistry, Royal Institute of Technology, and Department of Biosciences at Novum, Huddinge, Sweden), $417 \mathrm{~g} / \mathrm{L}$ GJE and BLEX ( $\mathrm{n}=4)$, and $3 \mu \mathrm{M}$ ANF ( $n=3$, Sigma, St. Louis, USA).

\section{Human intervention study}

Three male and three female healthy non-smoking volunteers, aged 21-46 years, were recruited for a NAhRA-enriched dietary intervention study. No medication or vitamin supplementation was used by the subjects during the intervention (oral contraceptives were permitted). The protocol was approved by the Medical Ethical Committee of Maastricht University and the Academic Hospital Maastricht and the subjects were fully informed about the details of the study and gave their written informed consent. After a three day wash-out period, without consumption of cruciferous vegetables and citrus fruits, the participants received on three consecutive days $600 \mathrm{ml}$ of grapefruit juice, which was divided in three portions of $200 \mathrm{ml}$ distributed over the day. Again after a three week wash out period, the participants consumed on three consecutive days a soup containing 150 $\mathrm{g}$ broccoli per portion and a meal with $300 \mathrm{~g}$ Brussels sprouts. Blood samples were taken before, and $3 \mathrm{~h}$ and $24 \mathrm{~h}$ after the last NAhRA-enriched meal. Two types of blood samples were taken, one using Li-heparin containing tubes for isolation of lymphocytes (VenoSafe, Terumo, Leuven, Belgium), and another using PAXgene Blood RNA Tubes for rapid mRNA conservation in whole blood (PreAnalytiX, Qiagen, Crawley, UK).

\section{RNA isolation}

Total RNA was isolated from freshly isolated lymphocytes using Trizol (Invitrogen, Breda, The Netherlands) according to the manufacturer's protocol. Total RNA was isolated from the PAXgene Blood RNA Tubes also according to the manufacturer's protocol. In short, tubes were centrifuged at $4000 \mathrm{~g}$, after removal of the supernatant, the pellet was resolved in $4 \mathrm{ml}$ of RNase-free water, centrifuged again, and the pellet was dissolved in $350 \mu \mathrm{l}$ resuspension buffer. The sample was transferred to a microcentrifuge tube and incubated with $300 \mu \mathrm{l}$ binding buffer and $40 \mu \mathrm{l}$ proteinase $\mathrm{K}$ for $10 \mathrm{~min}$ at $55^{\circ} \mathrm{C}$. The lysate was transferred to a PAXgene Shredder spin column placed in a 2 $\mathrm{ml}$ processing tube and centrifuged for $3 \mathrm{~min}$ at $12000 \mathrm{~g}$. The flow-through fraction was mixed with $350 \mu \mathrm{l}$ ethanol and pipetted into the PAXgene RNA spin column placed in a $2 \mathrm{ml}$ processing tube and centrifuged for $1 \mathrm{~min}$ at $12000 \mathrm{~g}$. The column was washed with $350 \mu \mathrm{l}$ wash buffer 1 , centrifuged at $12000 \mathrm{~g}$ and $80 \mu \mathrm{l}$ of DNase incubation mix was added. After $15 \mathrm{~min}$ the sample was washed with wash buffers 1 and 2 respectively, eluted twice with $40 \mu$ elution buffer and incubated for $5 \mathrm{~min}$ at $65^{\circ} \mathrm{C}$. Purity and integrity of the RNA were checked by gel electrophoresis and UV-spectrometry. 


\section{Quantitative real-time RT-PCR}

One $\mu \mathrm{g}$ of total RNA was reverse transcribed into cDNA using iScript ${ }^{\mathrm{TM}}$ cDNA Synthesis Kit (BioRad, Hercules, CA, USA) in a final volume of $20 \mu$ l. For amplification of $\beta$-actin, CYP1A1, CYP1B1, and NQO1 the following primers were used:

$\boldsymbol{\beta}$-Actin: forward 5'- CCTGGCACCCAGCACAAT-3';

reverse 5'-GCCGATCCACACGGAGTACT-3';

CYP1A1: forward 5'-TCCTGGAGACCTTCCGACACT-3';

reverse 5'-CTTTCAAACTTGTGTCTCTTGTTGT-3';

CYP1B1: forward 5'-AGTGCAGGCAGAATTGGATCA-3';

reverse 5'-GCGCATGGCTTCATAAAGGA-3';

NQO1: forward 5'-GGTGGAGTCGGACCTCTATGC-3';

reverse 5'- CCTTCAGTTTACCTGTGATGTCCTT-3'.

$\beta$-Actin was used to normalize for differences in RNA input and efficiency during the reverse transcription. Samples were diluted 15 times and duplicates were mixed with primers and $\mathrm{iQ}^{\mathrm{TM}} \mathrm{SYBR}^{\circ}$ Green Supermix (Bio-Rad, Hercules, CA, USA) and amplification took place in the iCycler PCR machine with the MyiQ Single Color Real-Time PCR Detector System (Bio-Rad, Veenendaal, The Netherlands). The specificity of the PCR products was checked by melt curve peak analysis and by gel electrophoresis. Gene expression levels were calculated from the threshold cycle values and plotted as the ratio with the $\beta$-actin expression level.

\section{Microarray hybridisation}

Hybridisation of the samples was performed using the Agilent Low RNA Input Fluorescent Linear Amplification Kit (Agilent Technologies, Palo Alto, CA, USA). To a $1.5 \mathrm{ml}$ microcentrifuge tube, $400 \mathrm{ng}$ RNA in $10.3 \mu \mathrm{l}$ and $1.2 \mu \mathrm{l}$ of T7 Promotor Primer were added and incubated for $10 \mathrm{~min}$ at $65^{\circ} \mathrm{C}$. After cooling on ice, $8.5 \mu \mathrm{l}$ cDNA Master Mix was added and samples were first incubated at $40^{\circ} \mathrm{C}$ for $2 \mathrm{~h}$ and then at $65^{\circ} \mathrm{C}$ for $15 \mathrm{~min}$. To each sample, $1.2 \mu \mathrm{l}$ cyanine-3-CTP or cyanine-5-CTP ( $5 \mathrm{mM}$, Perkin Elmer, Boston, MA, USA) and $28.8 \mu \mathrm{l}$ of Transcription Master Mix were added, mixed and incubated at $40^{\circ} \mathrm{C}$ for $2 \mathrm{~h}$. Next, $50 \mu \mathrm{l}$ nuclease-free water, $350 \mu \mathrm{l}$ Buffer RLT, and 250 $\mu \mathrm{l}$ ethanol were added, and $700 \mu \mathrm{l}$ of the cRNA sample was transferred to an RNeasy mini column in a $2 \mathrm{ml}$ collection tube. The sample was centrifuged for $30 \mathrm{sec}$ at $13000 \mathrm{rpm}$, washed twice with $500 \mu \mathrm{l}$ buffer RPE and eluted twice with $30 \mu \mathrm{l}$ of RNase-free water. Yield and build-in of label were measured by use of the NanoDrop ND-1000 Spectrophotometer (Isogen Life Sciences, IJsselstein, The Netherlands). Of the linearly amplified Cy3- and Cy5-labeled cRNA, $1 \mu \mathrm{g}$ (or $0.5 \mu \mathrm{g}$ of 2 samples of GJE and 2 corresponding samples of BLEX, because their yield was too low) was mixed with $50 \mu \mathrm{l} 10 \mathrm{x}$ control targets solution and nuclease-free water up to $240 \mu \mathrm{l}, 10 \mu \mathrm{l} 25 \mathrm{x}$ fragmentation buffer was added and samples were incubated at $60^{\circ} \mathrm{C}$ for $30 \mathrm{~min}$ in the dark. Afterwards, $250 \mu \mathrm{l}$ $2 \mathrm{x}$ hybridization buffer was added, mixed and the solution was dispensed onto a gasket slide in a chamber base (In situ Hybridization Kit Plus, Agilent Technologies). The 22K Human 1A (V2) Oligo Microarray slide (Agilent Technologies) was gently placed on the gasket slide, the chamber cover 
was assembled and loaded into a hybridization rotator rack. Samples were hybridized at $60^{\circ} \mathrm{C}$ for 17 $\mathrm{h}$ at $4 \mathrm{rpm}$, washed with $6 \mathrm{x}$ SSPE/0.005\% N-lauroylsarcosine, 0.06x SSPE, 0005\% N-lauroylsarcosine and Stabilization and Drying Solution (Agilent Technologies) respectively. Slides were scanned with the Scan Array Express HT (Packerd BioScience, Boston, USA).

\section{Microarray data analysis}

The fluorescence signals were quantified using ImaGene 5.0 (BioDiscovery, Marina del Rey, CA, USA), poor spots, and spots with low expression levels were flagged, and background subtracted data were exported to Microsoft Excel. All flagged spots and spots with a lower signal than twice the background were removed and the remaining 4268 spots were normalized first by correcting the Cy5 signals with the Cy3 internal standard signals. Subsequently, the median of the adjusted $\mathrm{Cy} 5$ values was used to correct for possible differences between experiments with respect to the efficiency of labelling and the amount of label. Ratios of differential gene expression were calculated by dividing the normalized values of cells treated with test-sample by those treated with the solvent DMSO, and significance was calculated with the Student's t-test. Principle Component Analysis (PCA) was carried out with GeneMath 2.1 (Applied Maths, St-Martens-Latem, Belgium).

\section{Determination of enzyme activities by measuring caffeine metabolites in urine}

Caffeine is a substrate for CYP1A2, and also for CYP2A6, N-acetyltransferase 2 (NAT2) and xanthine oxidase (XO), all of which can be determined simultaneously by use of HPLC. The enzyme activities were determined by measuring the caffeine metabolites in urine as described before (Krul and Hageman, 1998). In short, the subjects were instructed to refrain from consumption of products containing caffeine for $24 \mathrm{~h}$, after which at least one cup of coffee or two cups of tea were consumed. Four hours after consumption, urine samples were collected and frozen immediately. This procedure was performed before and after the grapefruit juice and vegetable interventions. After addition of $120 \mathrm{mg}$ of ammonium sulphate, $200 \mu \mathrm{l}$ of urine and $200 \mu \mathrm{l}$ of internal standard ( $\mathrm{N}$-acetaminophen $150 \mathrm{mg} / \mathrm{l}$ ) were pipetted into a glass tube, and extracted with $6 \mathrm{ml}$ of chloroform/ isopropanol 4:1 (v/v). After centrifugation at $1000 \mathrm{~g}$ for $5 \mathrm{~min}$, the organic phase was evaporated at $40^{\circ} \mathrm{C}$ under a gentle stream of nitrogen, and the residue was dissolved in $1 \mathrm{ml}$ of $0.05 \%$ acetic acid. A $20 \mu \mathrm{l}$ aliquot of sample was injected onto a Hypersil $5 \mu \mathrm{m}$ ODS HPLC column ( $15 \mathrm{~cm} \times 4.6$ $\mathrm{mm}$ i.d.) from Phase Separations (Deeside, UK), eluted with $33 \%$ acetic acid:tetrahydrofuran:acetonitrile:milli-Q-water $(1: 2.5: 44: 952.5, \mathrm{v} / \mathrm{v})$ at a flow-rate of $1 \mathrm{ml} / \mathrm{min}$ and detected at a wavelength of $280 \mathrm{~nm}$ (UV-Vis SPD-6AV detector, Shimadzu, 's Hertogenbosch, The Netherlands). Identities of the caffeine metabolites 1-methylxanthine (1X), 1-methyluric acid (1U), 1,7 dimethylxanthine (17X), 1,7-dimethyluric acid (17U, Sigma Aldrich, Steinheim, Germany), and 5-acetylamino-6formylamino-3-methyluracil (AFMU, a kind gift from Dr. R. Fumeaux, Nestlé Research Centre, Lausanne, Switzerland) were determined by co injection. CYP1A2 activity was assessed by calculating the molar ratio $(\mathrm{AFMU}+1 \mathrm{X}+1 \mathrm{U}) / 17 \mathrm{U}$, CYP2A6 by $17 \mathrm{U} /(17 \mathrm{U}+17 \mathrm{X}+1 \mathrm{U}+1 \mathrm{X}+\mathrm{AFMU})$, NAT2 by AFMU/1X and XO by $1 \mathrm{U} /(1 \mathrm{U}+1 \mathrm{X})$. 


\section{Blood plasma extraction}

Of human blood plasma samples, $1.5 \mathrm{ml}$ was mixed with $2 \mathrm{ml}$ of 2-propanol (Biosolve BV, Valkenswaard, The Netherlands) and extracted twice with $4 \mathrm{ml}$ hexane/diethyl ether $(97 / 3 \mathrm{v} / \mathrm{v}$, Biolsolve BV). The hexane/diethyl ether layer was evaporated by a nitrogen flow and the residue was dissolved in $10 \mu \mathrm{DMSO}$ (Merck, Darmstadt, Germany), and subsequently diluted in $1 \mathrm{ml}$ cell exposure medium. For control, blank chemicals were extracted in the same way.

\section{DR CALUX assay}

The Dioxin Receptor - Chemical-Activated LUciferase gene eXpression assay was performed as described previously (Bovee et al., 1998). DR CALUX cells (rat H4IIE hepatoma cells stably transfected with pGudluc1.1, an AhR-regulated luciferase reporter plasmid) (Aarts et al., 1995) were grown in a-MEM (Sigma, St-Louis, USA), containing 10\% fetal bovine serum (GIBCO, Breda, The Netherlands) and $1 \%$ penicillin/streptomycin (Sigma), at $37^{\circ} \mathrm{C}$ and $5 \% \mathrm{CO}_{2}$. Cells were seeded in 48 well plates $24 \mathrm{~h}$ before exposure. Blood plasma samples from the donors of each sampling moment were pooled and diluted with cell medium to $15 \% \mathrm{v} / \mathrm{v}$ of the exposure medium (experiment 1 ), or extracted with hexane/diethyl ether (experiment 2, see 2.10). After $24 \mathrm{~h}$ exposure of the cells, the medium was removed and cells were washed with PBS. Cells were lysed using Cell Culture Lysis Reagent (Promega), centrifuged and $20 \mu$ of lysed solution of each well was transferred to a 96 wells plate. Luminescence was measured with a Luminoskan Ascent (Thermo Labsystems, Finland) upon addition of $0.1 \mathrm{ml}$ of assay mixture $\left(20 \mathrm{mM}\right.$ Tricine, $1.07 \mathrm{mM}\left(\mathrm{MgCO}_{3}\right)_{4} \mathrm{Mg}(\mathrm{OH})_{2} \cdot 5 \mathrm{H}_{2} \mathrm{O}, 2.67 \mathrm{mM}$ $\mathrm{MgSO}_{4} \cdot 7 \mathrm{H}_{2} \mathrm{O}, 0.1 \mathrm{mM}$ EDTA, $33.3 \mathrm{mM}$ DTT, $261 \mu \mathrm{M}$ Coenzyme A, $470 \mu \mathrm{M}$ Luciferin, $530 \mu \mathrm{M}$ ATP, $\mathrm{pH}$ 7.8). TCDD-equivalent (TEQ) values were calculated by use of the program SlideWrite V6 and the formula $\mathrm{a} 0 /\left(1+(\mathrm{x} / \mathrm{a} 1)^{\wedge} \mathrm{a} 2\right)$, which describes the AhR activation process suitably (Hoogenboom et al., 2006).

\section{Results}

\section{Effects of TCDD and NAhRAs in isolated human lymphocytes}

\section{Induction of AhR responsive genes in isolated human lymphocytes by TCDD}

Lymphocytes can be cultured either stimulated or non-stimulated. In the present study it was decided to use non-stimulated cells. The freshly isolated lymphocytes were used to determine the sensitivity of human lymphocytes to the activation of the AhR. Figure 1 shows that after exposure to a high, but non-cytotoxic amount of $5 \mathrm{nM}$ 2,3,7,8-tetrachlorodibenzo- $p$-dioxin (TCDD), the freshly isolated lymphocytes showed a highly significant up-regulation of CYP1B1 mRNA of 2.4 times after both $24 \mathrm{~h}$ and $72 \mathrm{~h}$. CYP1A1 mRNA was only markedly up-regulated in these cells at $72 \mathrm{~h}$, but could not be tested for significance ( $n=1$ ) (Fig. 1). These findings are in line with the results obtained with mitogen stimulated lymphocytes exposed to $10 \mathrm{nM}$ TCDD (van Duursen et al., 2005)

After $48 \mathrm{~h}$ of exposure to a ten-fold lower concentration of $500 \mathrm{pM}$ TCDD, freshly isolated lymphocytes of two other donors showed an up-regulation of CYP1A1 mRNA (14.3 and 3.3-fold 
resp. The large variation was caused by very low amounts of mRNA), CYP1B1 mRNA (1.5 and 1.3fold resp.), and NQO1 mRNA (1.8 and 2.0-fold resp.) (Fig. 2). It was decided to use these exposure conditions for TCDD and equivalent amounts of NAhRAs in the following experiments.

\section{Modulation of gene expression by TCDD, NAhRAs and the AhR antagonist ANF}

Freshly isolated lymphocytes from volunteers were exposed in vitro for $48 \mathrm{~h}$ to $500 \mathrm{pM}$ TCDD, $100 \mathrm{nM}$ indolo[3,2-b]carbazole (ICZ), 417 geq./L grapefruit juice extract (GJE), an extraction blank (BLEX), and $3 \mu \mathrm{M} \alpha$-naphtoflavone (ANF). Principal Component Analysis (PCA) with discriminant analyses of all 4268 selected genes showed a clustering of TCDD and ICZ treatments and separate clusters of GJE, BLEX and ANF treatments (Fig. 3). The genes which contributed most clearly to the effect of TCDD are listed in Table 1. A fold change limit of 1.5-2.0 and a $t$-test $P$-value of 0.05 would be preferable (Guo et al., 2006), but not many genes met these criteria. Therefore we applied the less stringent criteria of a fold change of 1.3 and a $P$-value of 0.2 (Table 1). Of the 24 genes listed in Table 1, only CYP1B1 and TIPARP (TCDD-inducible poly(ADP-ribose) polymerase) have been described as AhR responsive in literature (Hankinson, 1995; Ma et al., 2001). Several of the well-known AhR-responsive genes, including CYP1A1, CYP1A2 and MMP1, were below the detection limit in our microarray experiment. The expression changes of CYP1B1, TIPARP and two other known AhR-responsive genes, NQO1 and GSTP1 upon exposure to TCDD, ICZ, GJE, BLEX

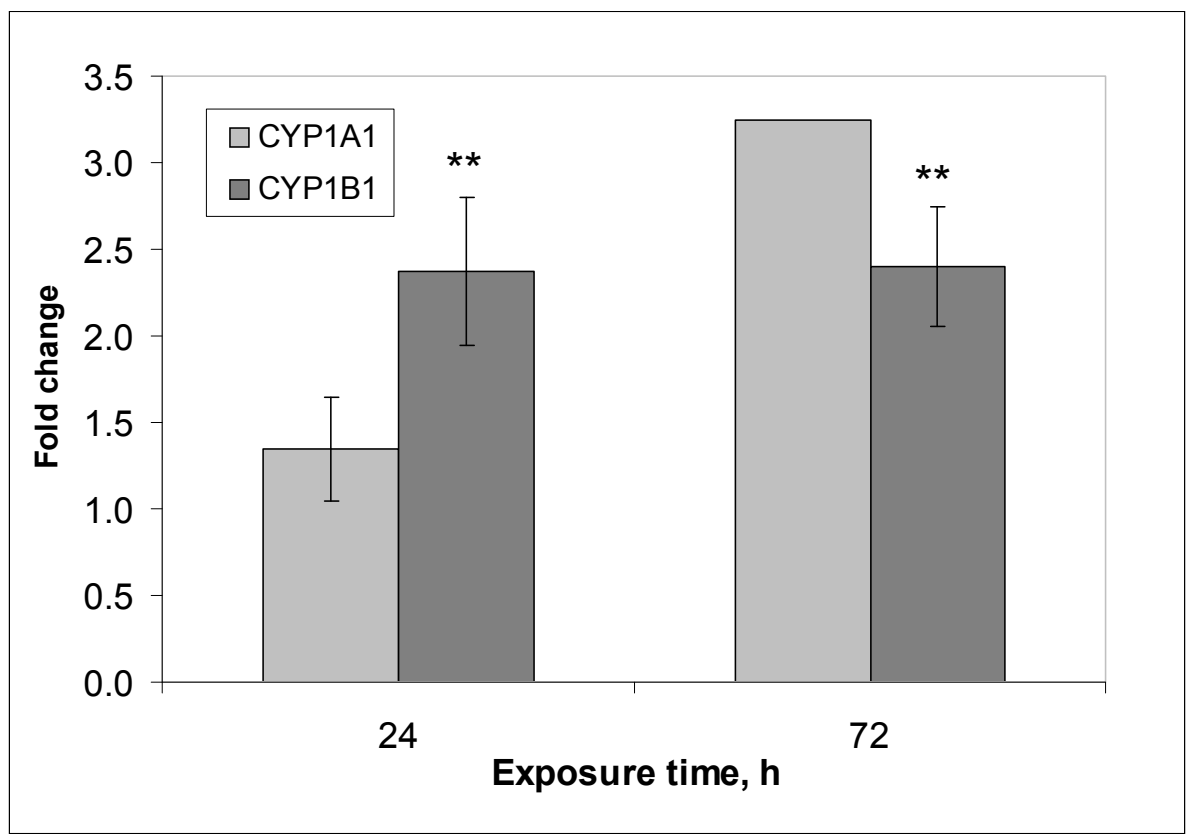

Fig.1. Fold change in amount of CYP1A1 mRNA and CYP1B1 mRNA in freshly isolated human lymphocytes after exposure to $5000 \mathrm{pM}$ TCDD as measured by RT-PCR. Mean of four samples from one donor (except for CYP1A1, 72h: one sample) \pm SD, ${ }^{* *} \mathrm{p}<0.01$ vs DMSO control. 


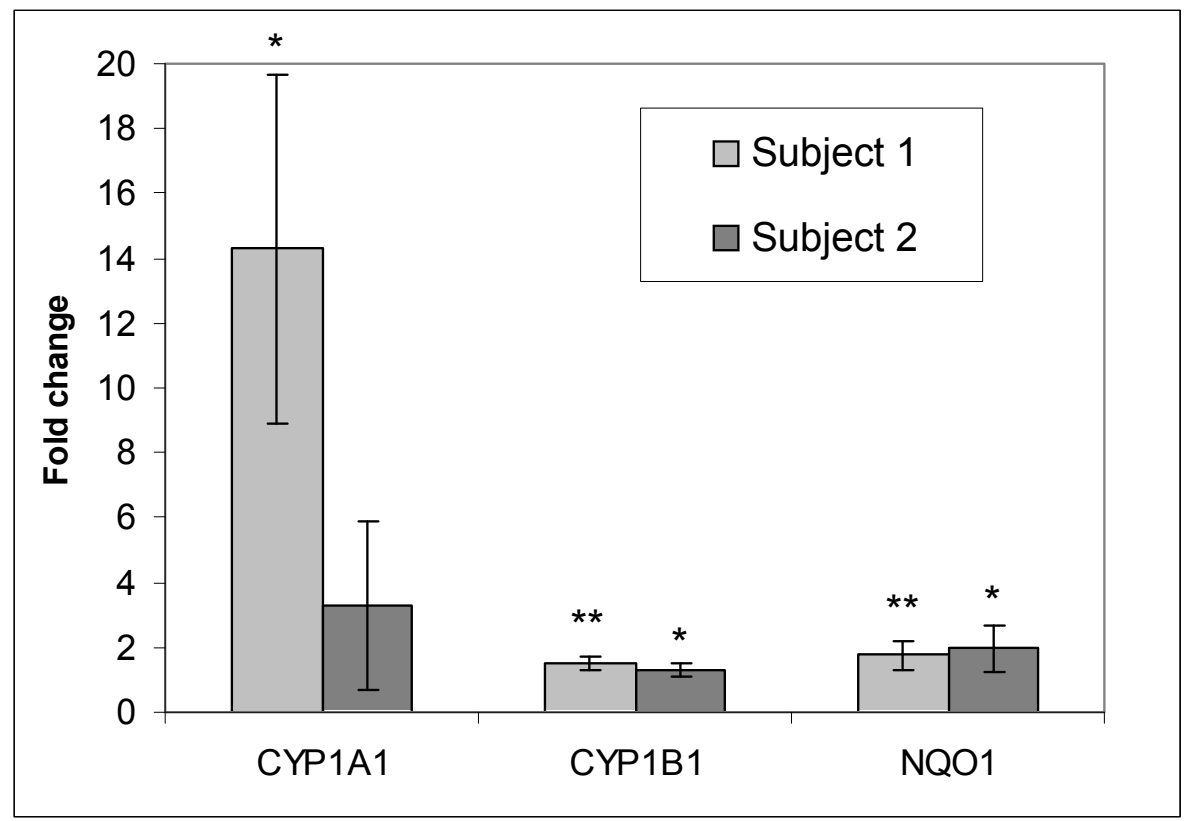

Fig. 2. Fold change in amount of CYP1A1 mRNA, CYP1B1 mRNA and NQO1 mRNA in freshly isolated human lymphocytes of two donors after exposure for $48 \mathrm{~h}$ to $500 \mathrm{pM}$ TCDD as measured by RT-PCR. Mean of 3 $(\mathrm{CYP} 1 \mathrm{~A} 1)$ or 4 samples $\left(\mathrm{CYP} 1 \mathrm{~B} 1\right.$ and NQO1) $\pm \mathrm{SD},{ }^{*} \mathrm{p}<0.1$ and ${ }^{* *} \mathrm{p}<0.05$ vs DMSO control.

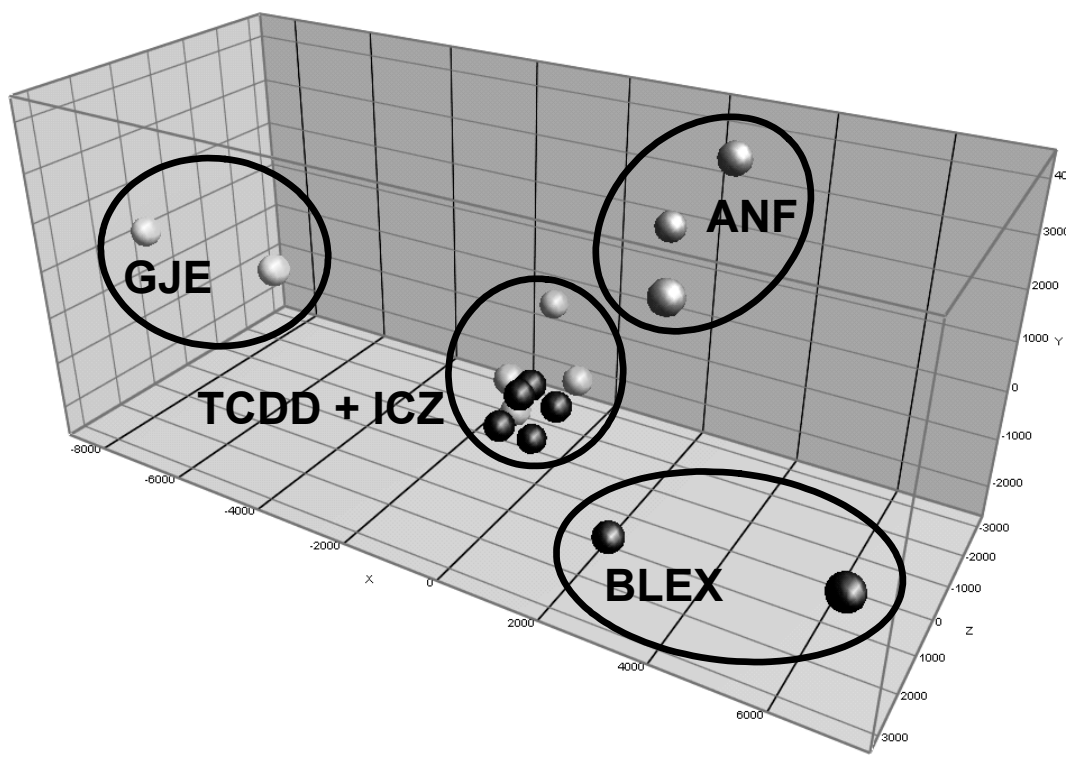

Fig. 3. PCA-plot with discriminant analyses of the fold changes of 4268 genes in human lymphocytes exposed ex vivo during $48 \mathrm{~h}$. TCDD + ICZ, 500 pM TCDD (dark dots) and $100 \mathrm{nM} \mathrm{ICZ} \mathrm{(light} \mathrm{dots);} \mathrm{GJE,} \mathrm{grapefruit} \mathrm{juice}$ extract; BLEX, blank extract; ANF, $3 \mu \mathrm{M} \alpha$-naphtoflavone. The variance can be explained for resp. $43.9 \%, 24.8 \%$ and $17.2 \%$ by the first three components. 
Table 1A. Mean fold changes in expression of 24 genes which were most prominently affected (fold change $>$ 1.3 up or down; $p<0.2$ ) after exposure of freshly isolated human lymphocytes to $500 \mathrm{pM}$ TCDD. Also listed is the fold change of same 24 genes after exposure to $100 \mathrm{nM}$ indolo[3,2-b]carbazole (ICZ), grapefruit juice extract (GJE), blank extraction (BLEX) and $3 \mu \mathrm{M} \alpha$-naphtoflavone (ANF). Fold changes were determined by microarray analysis and are the average of ex vivo exposed lymphocytes obtained from 5 (TCDD), 4 (ICZ), 3 (ANF), respectively 2 donors (GJE and BLEX).

\begin{tabular}{|c|c|c|c|c|c|c|c|c|c|}
\hline \multirow{3}{*}{$\begin{array}{l}\text { Gene symbol } \\
\text { CYP1B1 }\end{array}$} & \multirow{3}{*}{$\begin{array}{l}\text { Acc. No. } \\
\text { NM_000104 }\end{array}$} & \multicolumn{8}{|c|}{ Fold change } \\
\hline & & \multicolumn{2}{|l|}{ TCDD } & \multicolumn{2}{|l|}{ ICZ } & \multirow{2}{*}{$\begin{array}{c}\text { GJE } \\
0.80\end{array}$} & \multirow{2}{*}{$\begin{array}{l}\text { BLEX } \\
0.99\end{array}$} & \multicolumn{2}{|l|}{ ANF } \\
\hline & & 1.73 & $* *$ & 1.76 & $* *$ & & & 0.52 & $\ddagger$ \\
\hline RPL39 & NM_001000 & 1.44 & * & 1.03 & & 0.97 & 1.01 & 0.99 & \\
\hline YPEL5 & NM_016061 & 1.40 & $* *$ & 1.39 & * & 0.87 & 1.29 & 1.12 & \\
\hline TIPARP & NM_015508 & 1.40 & * & 1.46 & $* *$ & 0.98 & 1.27 & 0.54 & $\ddagger$ \\
\hline MTCO2 & NM_173705 & 1.37 & $* *$ & 1.06 & & 1.25 & 0.90 & 1.06 & \\
\hline ERBP & NM_014597 & 1.36 & $* * *$ & 1.23 & * & 1.05 & 1.16 & 1.14 & * \\
\hline S100A8 & NM_002964 & 1.35 & $* *$ & 1.51 & * & 1.45 & 0.66 & 1.20 & \\
\hline TTC11 & NM_016068 & 1.35 & * & 1.09 & & 0.93 & 0.90 & 1.25 & \\
\hline RPS4X & NM_001007 & 1.35 & $* *$ & 1.21 & & 0.85 & 1.25 & 0.91 & \\
\hline GRSF1 & NM_002092 & 1.35 & $* *$ & 0.94 & & 1.00 & 1.05 & 1.30 & \\
\hline S100A8 & NM_002964 & 1.34 & * & 1.48 & * & 1.47 & 0.61 & 0.77 & \\
\hline EVI2A & NM_014210 & 1.34 & * & 1.26 & * & 0.84 & 1.19 & 0.98 & \\
\hline COX7B & NM_001866 & 1.34 & * & 1.07 & & 0.96 & 1.04 & 1.11 & \\
\hline ALOX5AP & NM_001629 & 1.33 & $* * *$ & 1.29 & $* * *$ & 1.36 & 0.63 & 0.73 & ま \\
\hline TCF7 & NM_003202 & 1.32 & * & 1.05 & & 0.97 & 1.25 & 1.48 & $* * *$ \\
\hline AF241539 & AF241539 & 1.31 & $* *$ & 0.89 & & 0.87 & 1.01 & 0.94 & \\
\hline ATP5C1 & NM_005174 & 1.30 & $* *$ & 1.42 & & 0.99 & 0.73 & 0.96 & \\
\hline HIST1H4C & NM_003542 & 1.30 & * & 1.31 & & 1.03 & 1.56 & 1.31 & \\
\hline TNFRSF25 & NM_148965 & 0.77 & $* * *$ & 1.05 & & 1.19 & 1.42 & 1.23 & \\
\hline XRCC1 & NM_006297 & 0.77 & $* * *$ & 0.99 & & 0.96 & 1.17 & 0.98 & \\
\hline FLJ13769 & AK023831 & 0.76 & * & 0.76 & $* * *$ & 1.74 & 0.72 & 0.54 & $* * *$ \\
\hline ANKRD11 & NM_013275 & 0.75 & $* *$ & 0.78 & $* * *$ & 0.94 & 1.08 & 0.90 & \\
\hline HERC1 & NM_003922 & 0.75 & $* * *$ & 0.85 & & 0.98 & 0.99 & 0.83 & \\
\hline MGC4796 & NM_032017 & 0.74 & $* * *$ & 1.05 & & 1.17 & 0.87 & 0.94 & \\
\hline
\end{tabular}

Note: Significance of fold change in gene expression of samples compared to control blank:

${ }^{*} p<0.2,{ }^{* *} p<0.1,{ }^{* * *} p<0.05, \neq$ direction reversed with $p<0.2$

and ANF as analyzed by microarray are plotted in Fig. 4. No stringently significant up- or downregulation was observed, except for the down-regulation of TIPARP by ANF $(\mathrm{p}<0.05)$. A tendency of up-regulation of CYP1B1 and TIPARP by TCDD and ICZ $(p<0.1)$, and down-regulation of these genes by the antagonist ANF ( $p=0.15$ and $<0.05$ resp.) are noticeable. This tendency is consistent with the clustering of TCDD and ICZ shown in the PCA-plot (Fig.3).

\section{Human intervention study with cruciferous vegetables and grapefruit juice}

Human volunteers received cruciferous vegetables or grapefruit juice on three consecutive days, following a period without these products. Based on the results of a former study on DR CALUX measurements in foods (de Waard et al, in press), we calculated the amount of AhR agonists as 
Table 1B. Description of the Gene symbols.

\begin{tabular}{|c|c|}
\hline Gene symbol & Description \\
\hline CYP1B1 & Homo sapiens cytochrome $\mathrm{P} 450$, family 1 , subfamily $\mathrm{B}$, polypeptide 1 \\
\hline RPL39 & Homo sapiens ribosomal protein L39 \\
\hline YPEL5 & Homo sapiens yippee protein (CGI-127) \\
\hline TIPARP & Homo sapiens TCDD-inducible poly(ADP-ribose) polymerase \\
\hline MTCO2 & Homo sapiens cytochrome $\mathrm{c}$ oxidase II \\
\hline ERBP & Homo sapiens acidic $82 \mathrm{kDa}$ protein mRNA (HSU15552) \\
\hline S100A8 & Homo sapiens S100 calcium binding protein A8 (calgranulin A) \\
\hline TTC11 & Homo sapiens tetratricopeptide repeat domain 11 \\
\hline RPS4X & Homo sapiens ribosomal protein S4, X-linked \\
\hline GRSF1 & Homo sapiens G-rich RNA sequence binding factor 1 \\
\hline S100A8 & Homo sapiens S100 calcium binding protein A8 (calgranulin A) \\
\hline EVI2A & Homo sapiens ecotropic viral integration site $2 \mathrm{~A}$ \\
\hline COX7B & Homo sapiens cytochrome c oxidase subunit VIIb (COX7B) \\
\hline ALOX5AP & Homo sapiens arachidonate 5-lipoxygenase-activating protein \\
\hline TCF7 & Homo sapiens transcription factor 7 (T-cell specific, HMG-box) \\
\hline AF241539 & Homo sapiens ncaml mRNA, complete cds \\
\hline ATP5C1 & $\begin{array}{l}\text { Homo sapiens ATP synthase, } \mathrm{H}+\text { transporting, mitochondrial F1 complex, gamma } \\
\text { polypeptide } 1\end{array}$ \\
\hline HIST1H4C & Homo sapiens histone $1, \mathrm{H} 4 \mathrm{c}$ (HIST1H4C) \\
\hline TNFRSF25 & Homo sapiens tumor necrosis factor receptor superfamily, member 25 \\
\hline XRCC1 & Homo sapiens X-ray repair complementing defective repair in Chinese hamster cells 1 \\
\hline FLJ13769 & Homo sapiens cDNA FLJ13769 fis, clone PLACE4000222. \\
\hline ANKRD11 & Homo sapiens ankyrin repeat domain 11 (ANKRD11) \\
\hline HERC1 & Homo sapiens hect (homologous to the E6-AP (UBE3A) carboxyl terminus) domain \\
\hline MGC4796 & Homo sapiens Ser/Thr-like kinase \\
\hline
\end{tabular}

measured by the DR CALUX' assay in the Brussels sprouts intervention to be an extra 0.9-1.6 ng TCDD equivalents/day and in the grapefruit juice intervention to be an extra 14-20 ng TCDD equivalents/day. Blood samples were taken before, and 3 and $24 \mathrm{~h}$ after the last NAhRA-enriched diet.

\section{AhR related gene expression in human blood cells}

The mRNA levels of the prototypically AhR-responsive genes coding for CYP1A1, CYP1B1 and NQO1 before and after consumption of grapefruit juice and cruciferous vegetables, were determined in blood cells by quantitative RT-PCR (Fig.5). No significant up- or down-regulation of the three investigated genes, or differences between samples taken $3 \mathrm{~h}$ or $24 \mathrm{~h}$ after exposure was observed in the isolated lymphocytes or in the whole blood cells, both for the intervention with grapefruit juice and with cruciferous vegetables. CYP1A1 mRNA could not be detected in the PAX gene obtained total RNA of blood cells because of the very low amount of CYP1A1 mRNA. 


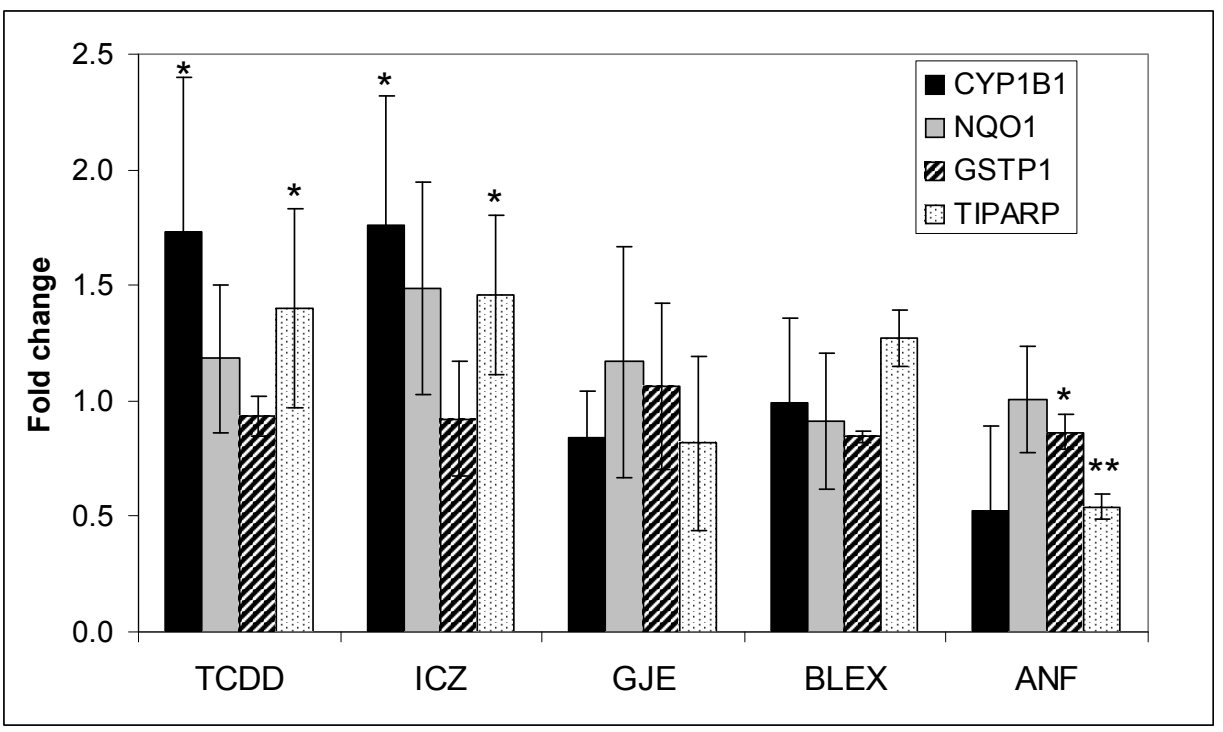

Fig. 4. Fold change in four AhR-responsive gene products as determined by microarray, after 48h exposure of freshly isolated human lymphocytes to $500 \mathrm{pM}$ TCDD, $100 \mathrm{nM} \mathrm{ICZ,} \mathrm{grapefruit} \mathrm{juice} \mathrm{extract} \mathrm{(GJE),} \mathrm{blank} \mathrm{extract}$ (BLEX) and $3 \mu \mathrm{M} \alpha$-naphtovlavone (ANF). Mean $\pm \mathrm{SD},{ }^{*} \mathrm{p}<0.1,{ }^{* \star} \mathrm{p}<0.05$ vs DMSO control.

\section{Biotransformation enzyme activities as determined by urinary caffeine metabolites}

Before and after the interventions with grapefruit juice and cruciferous vegetables the activities of the four biotransformation enzymes CYP1A2, CYP2A6, NAT2 and XO were determined by calculating the ratios of caffeine metabolites in urine. Changes in enzyme activity are shown as ratios and plotted in Fig. 6. Consumption of grapefruit juice slightly reduced the activity of CYP1A2 and significantly reduced the activity of NAT2 down to $70 \%$. Consumption of cruciferous vegetables did not show any significant changes in enzyme activity (Fig. 6).

\section{AhR activity in blood plasma as determined by DR CALUX}

During the three day NAhRA-enriched diet intervention study, blood plasma samples were collected before the first consumption, and $3 \mathrm{~h}$ and $24 \mathrm{~h}$ after the last consumption of grapefruit juice or cruciferous vegetables. The presence of AhR agonists, as measured in pooled plasma samples by use of the DR CALUX' assay, showed a significant decrease after $3 \mathrm{~h}$ and a smaller, non-significant decrease after $24 \mathrm{~h}$ of the last grapefruit juice consumption. No significant effects were found after the intervention with cruciferous vegetables (results not shown). In this case, the blood plasma was directly mixed with the incubation medium of the cells, which was limited to $15 \%(\mathrm{v} / \mathrm{v})$, and the signal levels were relatively low. In order to obtain higher signal levels and so decreasing the detection limit, we concentrated the plasma samples by extraction with hexane/diethyl ether (97/3), which resulted in similar findings, but as expected, higher signal levels with an overall lesser deviation (Fig. 7). Both time intervals showed a small but significant $12 \%$ increase of DR CALUX activity after the 

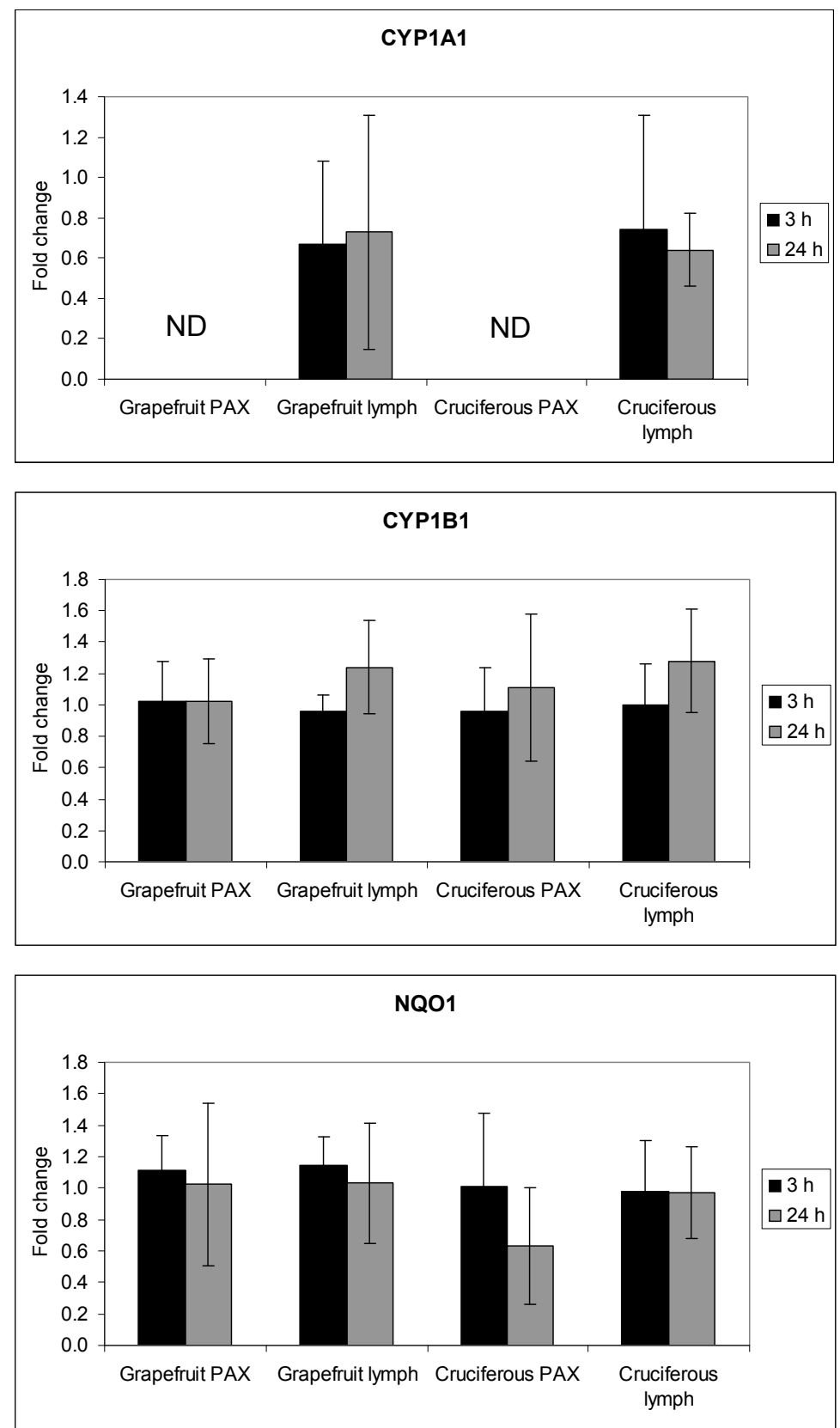

Fig. 5. Fold change in three prototypical AhR-responsive mRNAs (CYP1A1, CYP1B1, and NQO1 mRNA) in human blood cells from 5 to 6 volunteers as determined by RT-PCR. Samples were taken before, $3 \mathrm{~h}$ and $24 \mathrm{~h}$ after the last consumption of grapefruit juice or cruciferous vegetables of a three day intervention. Data expressed in comparison to the sample taken before the intervention. Mean \pm SD; ND, not detectable; PAX, blood from PreAnalytiX RNA tubes; lymph, freshly isolated peripheral blood lymphocytes. 


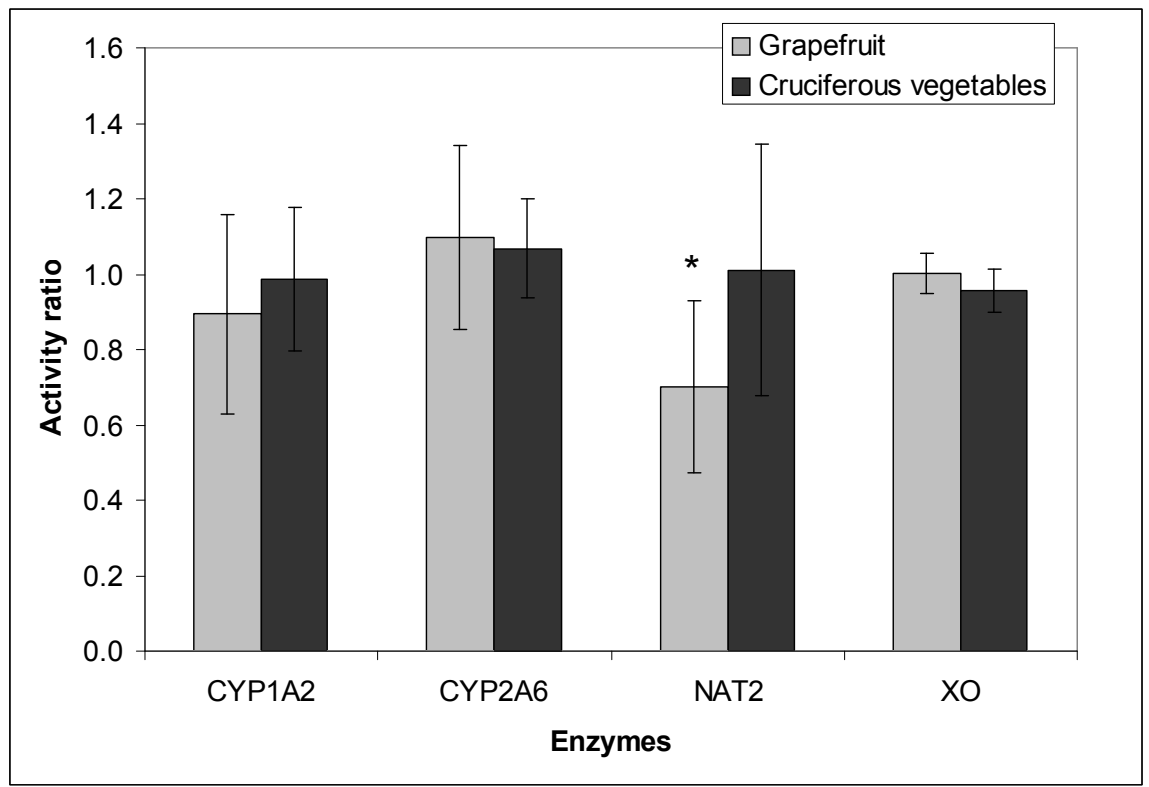

Fig. 6. Relative biotransformation enzyme activities in 5 to 6 volunteers before and after consumption of grapefruit juice or cruciferous vegetables, determined by HPLC analysis of urinary caffeine metabolites. Mean \pm $\mathrm{SD},{ }^{*} \mathrm{p}<0.05$ vs before intervention.

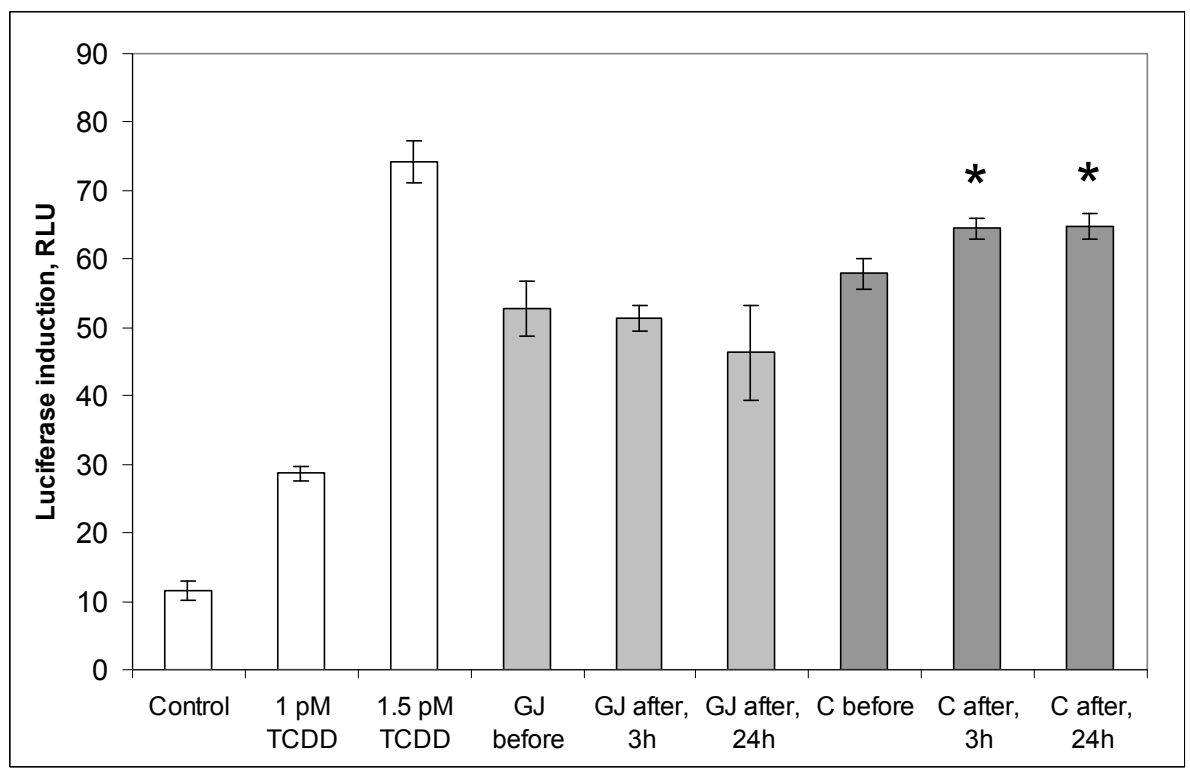

Fig. 7. AhR activation by extracts of blood plasma samples from human volunteers before and after ( $3 \mathrm{~h}$ and $24 \mathrm{~h}$ ) three days of intervention with grapefruit juice (GJ) or cruciferous vegetables (C), determined as luciferase induction in DR-CALUX ${ }^{\circledast}$ cells. Control is blank extraction with the chemicals, but without plasma. Data were corrected for the response obtained with the solvent DMSO. Mean $\pm \mathrm{SD}$; $\mathrm{p}<0.05$ for difference with the response measured before the intervention. 
cruciferous vegetable intervention, and an insignificant $12 \%$ decrease $24 \mathrm{~h}$ after the grapefruit juice intervention. All plasma samples showed a significantly higher signal than the blank extraction control, with levels between those of the 1 and 1.5 pM TCDD-standards (Fig.7).

\section{Discussion}

In contrast to the AhR-mediated toxic responses induced by environmental contaminants such as TCDD, exposure to natural AhR-agonists by consumption of citrus fruits and vegetables is generally associated with beneficial health effects. Insight in the molecular pathways modulated by NAhRAs after binding to the AhR, and detection of possible AhR-related modulation of these pathways in human tissues may be of great value for the risk-benefit analysis of these dietary constituents. In order to identify AhR related pathways in human blood cells, we analyzed gene expression modulation in peripheral lymphocytes ex vivo exposed to TCDD and NAhRAs, and analyzed blood samples from human volunteers intervened with a NAhRA-enriched diet.

The well-known AhR-regulated gene products CYP1A1, and CYP1B1 have been determined previously in blood cells from workers accidentally exposed to dioxins and related AhR agonists, but there is no consensus about the reliability of these two genes as biomarkers for AhR agonist exposure (Spencer et al., 1999; Toide et al., 2003; Landi et al., 2005; van Duursen et al., 2005). Therefore, it was of interest to establish if other genes, preferentially or specifically expressed in blood cells, are also affected by exposure to AhR agonists, potentially showing higher levels of upor down-regulation than CYP1A1 and CYP1B1. By using quantitative RT-PCR the up-regulation of the genes coding for CYP1A1, CYP1B1 and NQO1 could be reproducibly detected in ex vivo exposed human lymphocytes (Fig 1 and 2). However, the response of these genes was relatively moderate as compared to the induction levels reported for other human cells, like hepatoma, lung and colon cells (Puga et al., 2000; Martinez et al., 2002). The $22 \mathrm{~K}$ gene microarray used in this study did not reveal genes significantly more affected by TCDD than CYP1B1 (Table 1).

ICZ showed some overall TCDD-like gene expression modulation in lymphocytes, whereas GJE and ANF showed no TCDD-like effect whatsoever (Table 1). Interestingly, the two genes that are known to be responsive to AhR activation, CYP1B1 and TIPARP, are both linked to tumor formation (Spink et al., 1998; Ma et al., 2001; Katoh, 2003; Peter Guengerich et al., 2003) and CYP1B1 was already proposed as a biomarker for AhR activation in human lymphocytes (Spencer et al., 1999). As expected, the AhR antagonist ANF does not affect these genes in the same way. Also the fold change in mRNA of NQO1 caused by ICZ resembles the up-regulation by TCDD more than those caused by GJE and ANF (Fig. 4). The established AhR-responsive gene for GSTP1 was neither affected by TCDD, nor by ICZ, suggesting that up-regulation of this gene is possibly cell type-specific. Together with the PCA results (Fig. 3) all this shows that there is a resemblance in gene expression between exposure to TCDD and ICZ, which is in agreement with our results from a microarray experiment with human colon Caco-2 cells (De Waard et al., 2007). In contrast, GJE does not induce a TCDDlike gene expression modulation in this study (Table 1, Figs. 3 and 4). This may also be a cell specific effect, or, in view of the longer exposure time of $48 \mathrm{~h}$ compared to the $24 \mathrm{~h}$ in our previous study, 
this difference may possibly be caused by instability of the AhR activating compounds in GJE, most likely furocoumarins like bergamottin.

In view of the apparent TCDD-like response in lymphocytes induced by ICZ, and the AhR activation by GJE observed in the former Caco-2 study, we performed a human intervention study with NAhRA-containing foods, to investigate if a response of AhR-controlled genes could be detected in vivo. With quantitative RT-PCR the gene expression of CYP1A1, CYP1B1 and NQO1 was determined before, shortly after $(3 \mathrm{~h})$ and longer after $(24 \mathrm{~h})$ the intervention. However, no significant effect on the regulation of these genes could be detected, neither in total blood cells collected by the PAX gene system, nor in freshly isolated lymphocytes, both shortly and longer after the 3-day intervention period (Fig. 5). Possibly the doses of NAhRAs were too low, or the exposure time was too short, to measure any effects. In other studies comparable amounts and exposure times of cruciferous vegetables produced AhR related effects in humans, e.g. induction of AhR responsive glutathione-S-transferase isozymes, or CYP1A2 induction measured by caffeine metabolism after consumption of 300 to $500 \mathrm{~g}$ of cruciferous vegetables (Nijhoff et al., 1995; Kall et al., 1996; Lampe et al., 2000). However, by using the caffeine metabolism assay, we could not detect an up-regulation of CYP1A2 enzyme activity (Fig. 6). Moreover, we did observe a down-regulation of the phase II enzyme NAT2 by the grapefruit juice intervention (Fig. 6), which has not yet been described in literature as an AhR-mediated effect. Because grapefruit components can inhibit the catalytic activity of many biotransformation enzymes, especially by its constituent bergamottin (Goosen et al., 2004), possibly these components can also inhibit the enzyme activity of NAT2. Relatively small doses of grapefruit juice, once or a few times repeatedly, showed a clear CYP3A4 inhibition in human studies, which is ascribed to bergamottin (Goosen et al., 2004). Furthermore, the low micromolar range concentrations of bergamottin applied here are within the concentration range reported to result in AhR-mediated induction of CYP1A1 gene expression (Baumgart et al., 2005). This implies that theoretically, the amount of grapefruit juice used in our intervention study should be high enough to activate the AhR.

The estimated amounts of AhR agonists as measured by the DR CALUX assay of 0.9-20 ng TCDDequivalents/day extra in the intervention diets seems considerably high in comparison with the estimated intake of the sum of dioxins and dioxin-like PCBs in The Netherlands, namely $1.2 \mathrm{pg}$ WHOTEQ (Toxic EQuivalents) per kg body weight (bw) per day, which would be for a person weighing 70 kg 84 pg WHO-TEQ (Baars et al., 2004). However, measurements of AhR-activity in blood plasma by use of the very sensitive reporter gene assay DR CALUX detected a low level of activity after consuming cruciferous vegetables. On the contrary, after the intervention with grapefruit juice, the activity even decreased (Fig. 7), which suggests that there is more AhR-antagonistic activity in these vegetables than agonistic activity. An explanation for the absence of AhR-response in blood cells may be the presence of high amounts of other sources of AhR agonists or antagonists in other foods, which mask the effects of grapefruit juice and cruciferous vegetables (Amakura et al., 2003a; Amakura et al., 2003b; Jeuken et al., 2003). The response observed in the DR CALUX' assay corresponds with a level of $0.5-1.5 \mathrm{pg}$ TCDD/g blood plasma, which is relatively high compared to the reported average 
of 0.12-0.25 pg TEQ/g plasma (based on an average of 25.4 pg TEQ/g lipid and 0.5-1\% serum lipid) (Warner et al., 2005). Connor et al. found even higher TCDD-equivalents in blood measured by DR CALUX in an intervention study, comparable with ours. Blood collected during a baseline diet contained 13-64 pg TCDD-equivalents/g, and after consumption of cruciferous vegetables 20-133 pg TCDD-equivalents/g, a significant increment. Consumption of pure I3C-supplements showed even levels of 62-218 pg TCDD-equivalents/g whole blood (Connor et al., 2004). The difference with our results may be partly explained by their CALUX measurement. Connor et al used a mouse cell line, extracted the samples with tert-butyl-methyl ether and used a very short exposure time of $4 \mathrm{~h}$. Shorter exposure times result often in a relatively high response from compounds other than TCDD because of the degradation of compounds by the cells and the relatively slow kinetics of the response to TCDD, which influences the outcome of the TEQ-calculations considerably. With a comparable CALUX method as used by Connor et al, Schecter et al. found a background level of $136 \mathrm{pg}$ TCDD induction equivalents (IEQ)/g blood in humans, using the term IEQ instead of TEQ, for the latter is in principle specific for dioxin-like compounds. These pooled samples contained $0.25 \mathrm{pg}$ TEQ/g blood when examined by using a clean-up procedure designed for detecting dioxin-like chemicals and GC-MS (Schecter, 1999). The $136 \mathrm{pg} / \mathrm{g}$ IEQ is about the average found in the I3C-supplement study of Connor et al, which suggests that the normal exposure to non-dioxin-like AhR agonists may be considerable.

We conclude that, although TCDD and the NAhRA ICZ do show AhR-mediated effects in ex vivo exposed human lymphocytes, the response of AhR related genes seems too low to use it as a sensitive biomarker for exposure to NAhRA-containing foods added to the normal human diet. More reliable, but also more invasive and much less readily available, would be obtaining bioptic material from target tissues like liver and colon.

Also other ways of detection of AhR-activity (DR CALUX and caffeine metabolism) in the human body after consumption of significant amounts of NAhRA-containing foods failed to reveal clear effects related to the AhR. This indicates that the AhR-agonistic effects of NAhRAs in food may be very subtle, or influenced by a high background of AhR-agonists or -antagonists in food. A possible normal occurrence of relatively high amounts of AhR-mediating compounds in the human diet should therefore be taken into consideration for the risk/benefit evaluation of both NAhRAs and dioxin-like compounds.

\section{ACKNowledgements}

The authors thank the volunteers kindly for their contribution to the intervention study, Liza Portier for the DR CALUX measurements, and Jody Lugger for his contribution to the determination of caffeine metabolites. The study was supported by the Dutch Centre of Human Nutrigenomics (CHN). 


\section{REFERENCES}

Aarts, J. M., Denison, M. S., Cox, M. A., Schalk, M. A., Garrison, P. M., Tullis, K., de Haan, L. H., and Brouwer, A. (1995). Species-specific antagonism of Ah receptor action by 2,2'5,5'-tetrachloro- and 2,2'3,3'4,4'-hexachlorobiphenyl. Eur J Pharmacol 293, 463-474.

Amakura, Y., Tsutsumi, T., Nakamura, M., Kitagawa, H., Fujino, J., Sasaki, K., Toyoda, M., Yoshida, T., and Maitani, T. (2003a). Activation of the aryl hydrocarbon receptor by some vegetable constituents determined using in vitro reporter gene assay. Biol Pharm Bull 26, 532-539.

Amakura, Y., Tsutsumi, T., Sasaki, K., Yoshida, T., and Maitani, T. (2003b). Screening of the inhibitory effect of vegetable constituents on the aryl hydrocarbon receptor-mediated activity induced by 2,3,7,8-tetrachlorodibenzo-p-dioxin. Biol Pharm Bull 26, 1754-1760.

Baars, A. J., Bakker, M. I., Baumann, R. A., Boon, P. E., Freijer, J. I., Hoogenboom, L. A., Hoogerbrugge, R., van Klaveren, J. D., Liem, A. K., Traag, W. A., and de Vries, J. (2004). Dioxins, dioxin-like PCBs and non-dioxin-like PCBs in foodstuffs: occurrence and dietary intake in The Netherlands. Toxicol Lett 151, 51-61.

Baumgart, A., Schmidt, M., Schmitz, H. J., and Schrenk, D. (2005). Natural furocoumarins as inducers and inhibitors of cytochrome P450 1A1 in rat hepatocytes. Biochem Pharmacol 69, 657-667.

Bergman, J. (1970). Condensation of indole and formaldehyde in the presence of air and sensitizers. Tetrahedron 26, 3353-3355.

Bergman, J., Janosik, T., and Wahlstrom, N. (2001). Indolocarbazoles. In: Advances in heterocyclic chemistry, Academic Press. 80, 1-71.

Bovee, T. F., Hoogenboom, L. A., Hamers, A. R., Traag, W. A., Zuidema, T., Aarts, J. M., Brouwer, A., and Kuiper, H. A. (1998). Validation and use of the CALUX-bioassay for the determination of dioxins and PCBs in bovine milk. Food Addit Contam 15, 863-875.

Boverhof, D. R., and Zacharewski, T. R. (2006). Toxicogenomics in risk assessment: applications and needs. Toxicol Sci 89, 352-360.

Broadbent, T. A., and Broadbent, H. S. (1998). 1. The chemistry and pharmacology of indole-3-carbinol (indole3-methanol) and 3-(methoxymethyl)indole. [Part II]. Curr Med Chem 5, 469-491.

Connor, K., Harris, M., Edwards, M., Chu, A., Clark, G., and Finley, B. (2004). Estimating the Total TEQ in Human Blood from Naturally-Occurring vs. Anthropogenic Dioxins: A dietary Study. Organohalogen Compounds 66, 3408-3413.

Dashwood, R. H. (1998). Indole-3-carbinol: anticarcinogen or tumor promoter in brassica vegetables? Chem Biol Interact 110, 1-5.

De Waard, W. J., Aarts, J. M. M. J. G., Peijnenburg, A. A. C. M., Baykus, H., Talsma, E., Punt, A., De Kok, T. M. C. M., Van Schooten, F. J., and Hoogenboom, L. A. P. (2007). Gene expression profiling in Caco-2 human colon cells exposed to TCDD, benzo[a]pyrene, and natural Ah receptor agonists from cruciferous vegetables and citrus fruits. Toxicology in Vitro In press.

Denison, M. S., and Nagy, S. R. (2003). Activation of the aryl hydrocarbon receptor by structurally diverse exogenous and endogenous chemicals. Annu Rev Pharmacol Toxicol 43, 309-334.

Fernandez-Salguero, P. M., Hilbert, D. M., Rudikoff, S., Ward, J. M., and Gonzalez, F. J. (1996). Aryl-hydrocarbon receptor-deficient mice are resistant to 2,3,7,8-tetrachlorodibenzo-p-dioxin-induced toxicity. Toxicol Appl Pharmacol 140, 173-179.

Fletcher, N., Wahlstrom, D., Lundberg, R., Nilsson, C. B., Nilsson, K. C., Stockling, K., Hellmold, H., and Hakansson, H. (2005). 2,3,7,8-Tetrachlorodibenzo-p-dioxin (TCDD) alters the mRNA expression of critical genes associated with cholesterol metabolism, bile acid biosynthesis, and bile transport in rat liver: a microarray study. Toxicol Appl Pharmacol 207, 1-24.

Frueh, F. W., Hayashibara, K. C., Brown, P. O., and Whitlock, J. P., Jr. (2001). Use of cDNA microarrays to analyze dioxin-induced changes in human liver gene expression. Toxicol Lett 122, 189-203.

Goosen, T. C., Cillie, D., Bailey, D. G., Yu, C., He, K., Hollenberg, P. F., Woster, P. M., Cohen, L., Williams, J. A., Rheeders, M., and Dijkstra, H. P. (2004). Bergamottin contribution to the grapefruit juice-felodipine interaction and disposition in humans. Clin Pharmacol Ther 76, 607-617.

Guo, L., Lobenhofer, E. K., Wang, C., Shippy, R., Harris, S. C., Zhang, L., Mei, N., Chen, T., Herman, D., Goodsaid, F. M., Hurban, P., Phillips, K. L., Xu, J., Deng, X., Sun, Y. A., Tong, W., Dragan, Y. P., and Shi, L. (2006). Rat toxicogenomic study reveals analytical consistency across microarray platforms. Nat Biotechnol 24, 1162-1169. 
Hankinson, O. (1995). The aryl hydrocarbon receptor complex. Annu Rev Pharmacol Toxicol 35, 307-340.

Heber, D. (2004). Vegetables, fruits and phytoestrogens in the prevention of diseases. J Postgrad Med 50, 145149.

Heijne, W. H., Kienhuis, A. S., van Ommen, B., Stierum, R. H., and Groten, J. P. (2005). Systems toxicology: applications of toxicogenomics, transcriptomics, proteomics and metabolomics in toxicology. Expert Rev Proteomics 2, 767-780.

Herrmann, S., Seidelin, M., Bisgaard, H. C., and Vang, O. (2002). Indolo[3,2-b]carbazole inhibits gap junctional intercellular communication in rat primary hepatocytes and acts as a potential tumor promoter. Carcinogenesis 23, 1861-1868.

Hoogenboom, L. A., Goeyens, L., Carbonnelle, S., van Loco, J., Beernaert, H., Baeyens, W., Traag, W. A., Bovee, T. F., Jacobs, G., and Schoeters, G. (2006). The CALUX bioassay: Current status of its application to screening food and feed. Trends in Analytical Chemistry 25, 410-420.

Hoogenboom, R. (2002). The combined use of the CALUX bioassay and the HRGC/HRMS method for the detection of novel dioxin sources and new dioxin-like compounds. Environ Sci Pollut Res Int 9, 304306.

Jeuken, A., Keser, B. J. G., Khan, E., Brouwer, A., Koeman, J., and Denison, M. S. (2003). Activation of the Ah receptor by extracts of dietary herbal supplements, vegetables, and fruits. Journal of Agricultural and Food Chemistry 51, 5478-5487.

Kall, M. A., Vang, O., and Clausen, J. (1996). Effects of dietary broccoli on human in vivo drug metabolizing enzymes: evaluation of caffeine, oestrone and chlorzoxazone metabolism. Carcinogenesis 17, 793-799.

Katoh, M. (2003). Identification and characterization of human TIPARP gene within the CCNL amplicon at human chromosome 3q25.31. Int J Oncol 23, 541-547.

Krul, C., and Hageman, G. (1998). Analysis of urinary caffeine metabolites to assess biotransformation enzyme activities by reversed-phase high-performance liquid chromatography. J Chromatogr B Biomed Sci Appl 709, 27-34.

Lampe, J. W., King, I. B., Li, S., Grate, M. T., Barale, K. V., Chen, C., Feng, Z., and Potter, J. D. (2000). Brassica vegetables increase and apiaceous vegetables decrease cytochrome P450 1A2 activity in humans: changes in caffeine metabolite ratios in response to controlled vegetable diets. Carcinogenesis 21, 1157-1162.

Lampe, J. W., Stepaniants, S. B., Mao, M., Radich, J. P., Dai, H., Linsley, P. S., Friend, S. H., and Potter, J. D. (2004). Signatures of environmental exposures using peripheral leukocyte gene expression: tobacco smoke. Cancer Epidemiol Biomarkers Prev 13, 445-453.

Landi, M. T., Bergen, A. W., Baccarelli, A., Patterson, D. G., Jr., Grassman, J., Ter-Minassian, M., Mocarelli, P., Caporaso, N., Masten, S. A., Pesatori, A. C., Pittman, G. S., and Bell, D. A. (2005). CYP1A1 and CYP1B1 genotypes, haplotypes, and TCDD-induced gene expression in subjects from Seveso, Italy. Toxicology 207, 191-202.

Lynn, A., Collins, A., Fuller, Z., Hillman, K., and Ratcliffe, B. (2006). Cruciferous vegetables and colo-rectal cancer. Proc Nutr Soc 65, 135-144.

Ma, Q., Baldwin, K. T., Renzelli, A. J., McDaniel, A., and Dong, L. (2001). TCDD-inducible poly(ADP-ribose) polymerase: a novel response to 2,3,7,8-tetrachlorodibenzo-p-dioxin. Biochem Biophys Res Commun 289, 499-506.

Martinez, J. M., Afshari, C. A., Bushel, P. R., Masuda, A., Takahashi, T., and Walker, N. J. (2002). Differential toxicogenomic responses to 2,3,7,8-tetrachlorodibenzo-p-dioxin in malignant and nonmalignant human airway epithelial cells. Toxicol Sci 69, 409-423.

McHale, C. M., Zhang, L., Hubbard, A. E., Zhao, X., Baccarelli, A., Pesatori, A. C., Smith, M. T., and Landi, M. T. (2007). Microarray analysis of gene expression in peripheral blood mononuclear cells from dioxinexposed human subjects. Toxicology 229, 101-113.

Mimura, J., and Fujii-Kuriyama, Y. (2003). Functional role of AhR in the expression of toxic effects by TCDD. Biochimica Et Biophysica Acta-General Subjects 1619, 263-268.

Nebert, D. W., Roe, A. L., Dieter, M. Z., Solis, W. A., Yang, Y., and Dalton, T. P. (2000). Role of the aromatic hydrocarbon receptor and $[\mathrm{Ah}]$ gene battery in the oxidative stress response, cell cycle control, and apoptosis. Biochem Pharmacol 59, 65-85.

Nijhoff, W. A., Mulder, T. P., Verhagen, H., van Poppel, G., and Peters, W. H. (1995). Effects of consumption of brussels sprouts on plasma and urinary glutathione S-transferase class-alpha and -pi in humans. Carcinogenesis 16, 955-957. 
Noonan, C., and Noonan, P. W. (2006). Marketing dietary supplements in the United States: a review of the requirements for new dietary ingredients. Toxicology 221, 4-8.

Peter Guengerich, F., Chun, Y. J., Kim, D., Gillam, E. M., and Shimada, T. (2003). Cytochrome P450 1B1: a target for inhibition in anticarcinogenesis strategies. Mutat Res 523-524, 173-182.

Puga, A., Maier, A., and Medvedovic, M. (2000). The transcriptional signature of dioxin in human hepatoma HepG2 cells. Biochem Pharmacol 60, 1129-1142.

Schecter, A. J. S., Shane U.; Birnbaum, Linda S.; DeVito, Michael J.; Denison, Michael S.; Päpke, Olaf (1999). A Comparison and Discussion of Two Differing Methods of Measuring Dioxin-like Compounds: Gas Chromatography-Mass Spectrometry and the CALUX Bioassay - Implications for Health Studies. Organohalogen Compounds 40, 247-250.

Spencer, D. L., Masten, S. A., Lanier, K. M., Yang, X., Grassman, J. A., Miller, C. R., Sutter, T. R., Lucier, G. W., and Walker, N. J. (1999). Quantitative analysis of constitutive and 2,3,7,8-tetrachlorodibenzo-p-dioxininduced cytochrome P450 1B1 expression in human lymphocytes. Cancer Epidemiol Biomarkers Prev 8, 139-146.

Spink, D. C., Spink, B. C., Cao, J. Q., DePasquale, J. A., Pentecost, B. T., Fasco, M. J., Li, Y., and Sutter, T. R. (1998). Differential expression of CYP1A1 and CYP1B1 in human breast epithelial cells and breast tumor cells. Carcinogenesis 19, 291-298.

Steenland, K., Bertazzi, P., Baccarelli, A., and Kogevinas, M. (2004). Dioxin revisited: developments since the 1997 IARC classification of dioxin as a human carcinogen. Environ Health Perspect 112, 1265-1268.

Steinmetz, K. A., and Potter, J. D. (1996). Vegetables, Fruit, and Cancer Prevention: A Review. Journal of the American Dietetic Association 96, 1027-1039.

Sugihara, K., Kitamura, S., Yamada, T., Okayama, T., Ohta, S., Yamashita, K., Yasuda, M., Fujii-Kuriyama, Y., Saeki, K., Matsui, S., and Matsuda, T. (2004). Aryl hydrocarbon receptor-mediated induction of microsomal drug-metabolizing enzyme activity by indirubin and indigo. Biochem Biophys Res Commun 318, 571-578.

Toide, K., Yamazaki, H., Nagashima, R., Itoh, K., Iwano, S., Takahashi, Y., Watanabe, S., and Kamataki, T. (2003). Aryl hydrocarbon hydroxylase represents CYP1B1, and not CYP1A1, in human freshly isolated white cells: trimodal distribution of Japanese population according to induction of CYP1B1 mRNA by environmental dioxins. Cancer Epidemiol Biomarkers Prev 12, 219-222.

Van den Berg, M., Birnbaum, L., Bosveld, A. T., Brunstrom, B., Cook, P., Feeley, M., Giesy, J. P., Hanberg, A., Hasegawa, R., Kennedy, S. W., Kubiak, T., Larsen, J. C., van Leeuwen, F. X., Liem, A. K., Nolt, C., Peterson, R. E., Poellinger, L., Safe, S., Schrenk, D., Tillitt, D., Tysklind, M., Younes, M., Waern, F., and Zacharewski, T. (1998). Toxic equivalency factors (TEFs) for PCBs, PCDDs, PCDFs for humans and wildlife. Environ Health Perspect 106, 775-792.

van Duursen, M. B., Sanderson, J. T., and van den Berg, M. (2005). Cytochrome P450 1A1 and 1B1 in human blood lymphocytes are not suitable as biomarkers of exposure to dioxin-like compounds: polymorphisms and interindividual variation in expression and inducibility. Toxicol Sci 85, 703-712.

van Gils, C. H., Peeters, P. H., Bueno-de-Mesquita, H. B., Boshuizen, H. C., Lahmann, P. H., Clavel-Chapelon, F., Thiebaut, A., Kesse, E., Sieri, S., Palli, D., Tumino, R., Panico, S., Vineis, P., Gonzalez, C. A., Ardanaz, E., Sanchez, M. J., Amiano, P., Navarro, C., Quiros, J. R., Key, T. J., Allen, N., Khaw, K. T., Bingham, S. A., Psaltopoulou, T., Koliva, M., Trichopoulou, A., Nagel, G., Linseisen, J., Boeing, H., Berglund, G., Wirfalt, E., Hallmans, G., Lenner, P., Overvad, K., Tjonneland, A., Olsen, A., Lund, E., Engeset, D., Alsaker, E., Norat, T., Kaaks, R., Slimani, N., and Riboli, E. (2005). Consumption of vegetables and fruits and risk of breast cancer. Jama 293, 183-193.

Verhoeven, D. T., Goldbohm, R. A., van Poppel, G., Verhagen, H., and van den Brandt, P. A. (1996). Epidemiological studies on brassica vegetables and cancer risk. Cancer Epidemiol Biomarkers Prev 5, 733-748.

Warner, M., Eskenazi, B., Patterson, D. G., Clark, G., Turner, W. E., Bonsignore, L., Mocarelli, P., and Gerthoux, P. M. (2005). Dioxin-Like TEQ of women from the Seveso, Italy area by ID-HRGC/HRMS and CALUX. J Expo Anal Environ Epidemiol 15, 310-318.

Yu, J., Wang, L., Walzem, R. L., Miller, E. G., Pike, L. M., and Patil, B. S. (2005). Antioxidant activity of citrus limonoids, flavonoids, and coumarins. J Agric Food Chem 53, 2009-2014.

Zeligs, M. A. (2002). DIM and I3C: The real facts on safety. www.dimfaq.com/site/I3C-safety.htm. 



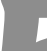
5

5

\section{Repeated exposure of green-fluorescent protein-} based reporter cells (DRE-CAFLUX) improved detection of non-persistent aryl hydrocarbon

\section{(Ah) receptor agonists in low concentrations in human blood plasma}

Pim W.J. de Waard ${ }^{\mathrm{a}}$, Laura H.J. de Haan ${ }^{\mathrm{b}}$, Matthéüs Wassens ${ }^{\mathrm{b}}$, Lubbartus C. van den Dikkenberg ${ }^{b}$, Frederik-Jan van Schooten a , Ad A.C.M. Peijnenburg c , Theo M.C.M. de Kok ${ }^{a}$, Ron L.A.P. Hoogenboom ${ }^{c}$, Jac M.M.J.G. Aarts ${ }^{b}$

\footnotetext{
a Department of Health Risk Analysis and Toxicology, NUTRIM, Maastricht University, PO box 616,

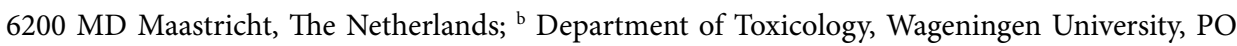
box 8000, 6700 EA Wageningen, The Netherlands; ${ }^{c}$ RIKILT Institute of Food Safety, Wageningen UR, PO box 230, 6700 EA Wageningen, The Netherlands
} 


\section{Abstract}

Activation of the aryl hydrocarbon receptor (AhR) is thought to be the major toxicity mechanism of dioxins and dioxin-like compounds. To screen environmental and food samples for the presence of AhR-agonists, the DR CALUX assay has been developed, which uses the luciferase reporter gene encoding a relatively unstable product. In this study, we investigated if the use of the DRE-CAFLUX bioassay, based on enhanced green-fluorescent protein (EGFP) as a reporter gene encoding a more stable product, would improve the detection limit of non-persistent AhR-agonists as compared to the DR CALUX ${ }^{\circ}$ assay. We hypothesized that repeated exposure of the DRE-CAFLUX cells would lower the limit of detection for unstable AhR-activating compounds, while this would not be the case for the DR CALUX" assay. After two extra exposures of the same cells to the biodegradable AhR-agonist benzo[a]pyrene, the detection limit in the DRE-CAFLUX was lowered by 10 times. Additionally, we measured the AhR-activity in human blood plasma samples from volunteers who consumed grapefruit juice or cruciferous vegetables containing natural AhR-agonists (NAhRAs). The bioassay cells were directly exposed to the samples and no differences before and after the intervention were shown in the DR CALUX ${ }^{\circ}$ assay. However, in the DRE-CAFLUX assay using repeated exposure, a significant increment of the signal was shown in plasma samples after consumption of cruciferous vegetables. We conclude that by use of repeated exposures, the DRE-CAFLUX assay can be a relatively sensitive, cheap and powerful tool for screening of large numbers of complex samples with low amounts of non-persistent AhR-agonists.
\end{abstract}




\section{INTRODUCTION}

The aryl hydrocarbon receptor (AhR) acts as a ligand-activated transcription factor and is present in most types of mammalian cells. The activated AhR complex translocates to the nucleus and binds to dioxin-responsive elements (DREs) occurring in the regulatory sequences of AhR-regulated genes resulting in the induction of, among others, the biotransformation enzymes CYP1A1, CYP1A2, CYP1B1, GSTP1 and UDPGT1A6. The dioxin 2,3,7,8-tetrachlorodibenzo-p-dioxin (TCDD) is one of the strongest AhR activators and the prototypical AhR-agonist. The activation of the AhR is considered to be the first step in the mechanism behind the toxic effects of dioxins and dioxin-like environmental pollutants (Hankinson, 1995; Safe, 2001). Also other types of compounds, like the polycyclic aromatic hydrocarbon benz $[a]$ pyrene $(\mathrm{BaP})$ and natural Ah-receptor agonists (NAhRAs), such as indoles originating from cruciferous vegetables and furanocoumarins in citrus fruits, can bind to and activate the AhR (Denison and Nagy, 2003; Van Ede et al., 2008). Whether these types of compounds may have a dioxin-like toxic potency is still under investigation.

The DR CALUX' (Dioxin Receptor Chemically-Activated LUciferase eXpression) bioassay has been developed as a high throughput screening assay for AhR agonist activity. Rat hepatoma H4IIE cells have been stably transfected with the reporter vector pGudLucl.1 containing a dioxin-responsive element-driven firefly (Photinus pyralis) luciferase gene. The induction of luciferase by AhR-agonists can be detected by addition of luciferin and measurement of the resulting bioluminescence (Aarts et al., 1995; Garrison et al., 1996). However, native firefly luciferase, the reporter protein used in the DRCALUX', has a C-terminal signal peptide targeting the expressed reporter protein to the peroxisomes of the cells (Keller et al., 1987) and displays relatively pronounced protein instability (Thompson et al., 1991) resulting in rapid inactivation. In addition, DR CALUX' (H4IIE rat hepatoma) cells are able to metabolize certain AhR agonists into inactive metabolites. As a result, the bioluminescence signal from the luciferase reporter protein induced by a rapidly metabolised AhR agonist, such as benzo[a]pyrene (Baird et al., 2005), will be only transiently detectable, and will rapidly extinguish after the inducer has been metabolised (Aarts et al., 1998; Hoogenboom et al., 1999). This short halflife of luciferase makes it a less suitable reporter for the detection of especially low levels of labile or biodegradable AhR-active compounds. As an alternative bioassay, the Dioxin Responsive Elementdriven Chemical-Activated FLUorescent protein eXpression (DRE-CAFLUX) assay was developed, using the same H4IIE rat hepatoma cells and the same dioxin-responsive regulatory sequence as applied in the DR CALUX' assay (Aarts et al., 1998). However, a more stable reporter protein was used. The DRE-CAFLUX cells contain a dioxin-responsive element-driven egfp reporter gene which encodes the enhanced version of a jellyfish (Aequoria Victoria) green-fluorescent protein (EGFP). This will remain stable and continue to be detectable by its characteristic fluorescence for many days (Chalfie et al., 1994). An additional advantage of the EGFP reporter protein is, that it can be measured non-destructively and real-time in living cells using a fluorimetric plate reader (Aarts et al., 1998). 
Recently, we performed a human intervention study with cruciferous vegetables and grapefruit juice, both food items containing relatively high levels of NAhRAs (De Waard et al., 2008), to investigate the levels of AhR-agonist activity attained in human blood plasma upon consumption of a NAhRArich diet (De Waard et al, submitted). The analysis of blood samples obtained from participants of this intervention study using the DR-CALUX' bioassay did not reveal a clear difference between samples taken before and after the intervention. However, the response obtained in the test was rather low, indicating the possibility that the sensitivity of the DR-CALUX was too low to detect potential differences due to the low input of NAhRAs into the assay resulting from direct measurement in blood plasma.

In the present study, we investigated whether the use of the DRE-CAFLUX, based on a more stable reporter protein, would improve the detection limit for low amounts of non-persistent AhRagonists as compared to the DR CALUX'. In addition, we investigated whether repeated exposure of the DRE-CAFLUX cells, which is supposed to result in a stepwise accumulation of EGFP reporter protein after each consecutive exposure, would even further improve the detection limit of the DRE-CAFLUX. The polycyclic hydrocarbon benzo[a]pyrene (BaP) was used as a model compound for rapidly metabolized AhR-agonists, and the blood plasma samples originating from the above mentioned NAhRA-intervention study were used as model samples with very low amounts of natural non-persistent AhR-agonists.

\section{Materials AND Methods}

\section{Materials}

HBSS, a-MEM medium, trypsin, Foetal Calf Serum (FCS) and gentamicin, were purchased from Invitrogen (Breda, The Netherlands), standard chemicals from Merck (Darmstadt, Germany), and TCDD from Schmidt B.V. (Amsterdam, The Netherlands). The TCDD stocks were checked by gas chromatography-mass spectrometry (GC-MS) for accurate concentrations. Molecularbiological reagents were from Bethesda Research Laboratories (Gaithersburg, MD, USA) and Roche (Mannheim, Germany). All other chemicals used were p.a. grade.

\section{Human NAhRA-enriched food intervention study}

This study is described in De Waard et al, submitted (see Chapter 4 in this thesis). In short: after a three day wash-out period, without consumption of cruciferous vegetables and citrus fruits, three male and three female healthy non-smoking volunteers received during three consecutive days 600 $\mathrm{ml}$ of grapefruit juice, which was divided in three portions of $200 \mathrm{ml}$ distributed over the day. Three weeks later and again after a three day wash-out period, the same participants consumed during three consecutive days a soup containing $150 \mathrm{~g}$ broccoli per portion and a meal with $300 \mathrm{~g}$ Brussels sprouts. During the intervention, no medication or vitamin supplementation was used by the subjects. Blood plasma samples were taken before, and $3 \mathrm{~h}$ and $24 \mathrm{~h}$ after the last NAhRA-enriched meal. The protocol was approved by the Medical-Ethical Committee of Maastricht University and 
the Academic Hospital Maastricht. The subjects were fully informed about the details of the study and gave their written informed consent.

\section{Construction of the DRE-CAFLUX reporter cell line}

The DRE-CAFLUX cell line was generated as briefly described in Aarts et al. (1998) by stable transfection of the H4IIE cell line purchased from ATCC with an EGFP reporter plasmid constructed analogous to pGudLuc1.1 used to generate the DR CALUX' cells (Aarts et al., 1995). A 1829 bp Hind III fragment was excised from the reporter construct pGudLuc1.1 containing a 1330 bp portion of the mouse mammary tumour virus (MMTV) long terminal repeat (LTR) promoter sequences, and in addition, four canonical DRE sequences derived from the mouse cyp la1 upstream gene regulatory region (Garrison et al., 1996). The promoter- and enhancer-less EGFP reporter vector pEGFP-1 (Clontech) was digested with Hind III and the 1810 bp vector fragment was gel-purified and ligated to the gel-purified Hind III fragment excised from pGudLuc1.1. The resulting pMDREegfp1.1 construct (Aarts et al., 1998), similar to pGreen1.1 (Nagy et al., 2002), was propagated in E. coli using standard recombinant DNA techniques (Sambrook et al., 1989). Subsequently, H4IIE cells were stably transfected with the pMDREegfp1.1 construct using DOTAP (N-[1-(2,3-Dioleoyloxy) propyl]-N,N,N-trimethylammonium methyl-sulfate) liposomal transfection reagent as prescribed by the manufacturer (Roche Diagnostics Nederland B.V., Almere, The Netherlands). The transfected cell population was diluted and plated in five tissue culture petri dishes (diameter $10 \mathrm{~cm}$ ) in $\alpha$-MEM culture medium containing $1 \mathrm{mg} / \mathrm{ml} \mathrm{G} 418$ (Geneticin, Gibco). Separate and rounded cell colonies were isolated from the petri dishes using cloning rings and propagated. To obtain the DRE-CAFLUX cell line, three consecutive rounds were applied of selecting the clone with the highest induction factor and absolute level of EGFP expression upon exposure to 1nM TCDD.

\section{DRE-CAFLUX assay}

DRE-CAFLUX cells were grown in a-MEM (Sigma-Aldrich Chemie B.V., Zwijndrecht, The Netherlands), containing $10 \%$ heat-inactivated fetal calf serum (Gibco, Invitrogen, Breda, The Netherlands), at $37^{\circ} \mathrm{C}, 5 \% \mathrm{CO}_{2}$, and $100 \%$ humidity. Cells were seeded in 96 -well plates (Greiner Bio-One cat. no. 655180, Alphen a/d Rijn, Netherlands) $24 \mathrm{~h}$ before exposure at $95-100 \%$ confluence in $100 \mu \mathrm{l}$ of medium per well and allowed to attach overnight. Concentration series of TCDD and $\mathrm{BaP}$ were made dissolved in DMSO. From these stocks, exposure medium was prepared by diluting the stocks 200 times into the required volume of culture medium without gentamicin and geneticin (final concentration of DMSO $0.5 \% \mathrm{v} / \mathrm{v}$ ). The resulting exposure medium was mixed on a plate shaker for at least $5 \mathrm{~min}$. before addition to the cells. Human blood plasma was spiked using the same TCDD working stocks by addition of $10 \mu \mathrm{l}$ from the TCDD stock with the appropriate concentration into $1 \mathrm{ml}$ plasma. To prepare exposure medium from (spiked) plasma samples, plasma was 10 times diluted in culture medium. Both TCDD and spiked plasma stocks were stored at $4^{\circ} \mathrm{C}$ to avoid precipitation of TCDD; plasma samples from the intervention study were stored at $-80^{\circ} \mathrm{C}$. All stocks were warmed in the incubator at least one hour and vortexed before addition to 
the medium. To expose the cells the culture medium in which they had been seeded was replaced by the appropriate exposure medium. Medium containing DMSO, respectively medium with $10 \% \mathrm{v} / \mathrm{v}$ human plasma and DMSO were used as a control. Cells were exposed in a tissue culture incubator at at $37^{\circ} \mathrm{C}, 5 \% \mathrm{CO} 2$, and $100 \%$ humidity. Fluorescence was measured real-time using the Cytofluor 2350 fluorescent plate reader (Millipore) with 485/530 nm excitation/emission filters. To preserve sterility and to allow repeated measurements, the lid was left on the plates during the measurements.

\section{DR CALUX assay}

DR CALUX cells (rat H4IIE hepatoma cells stably transfected with the AhR-regulated luciferase reporter plasmid pGudluc1.1) (Aarts et al., 1995) were grown in a-MEM (Sigma, St-Louis, USA), containing 10\% heat-inactivated fetal calf serum (Gibco, Invitrogen, Breda, The Netherlands), at $37^{\circ} \mathrm{C}, 5 \% \mathrm{CO} 2$, and $100 \%$ humidity. Cells were seeded in 96-well plates (Greiner Bio-One cat. no. 655180, Alphen a/d Rijn, Netherlands) $24 \mathrm{~h}$ before exposure at $95-100 \%$ confluence in $100 \mu \mathrm{l}$ of medium per well and allowed to attach overnight. Exposure medium containing test chemicals, human plasma and controls were prepared as described above for the DRE-CAFLUX. To expose the cells the culture medium above the cells was exchanged for $100 \mu$ of exposure medium. After the desired exposure time, the exposure medium was removed and cells were washed twice with diluted phosphate-buffered saline (PBS) (50\% demineralised water/50\% PBS v/v) and subsequently $30 \mu \mathrm{l}$ of Low Salt Buffer (10 mM Tris pH 7.8, 2 mM DTT)) was added to each well and the plate was frozen in a freezer at $-80^{\circ} \mathrm{C}$ during at least $30 \mathrm{~min}$. and thawed again to lyse the cells. Luciferase activity was measured using a Luminoskan luminometer (LabSystems) equipped with two injectors used to first inject100 $\mu \mathrm{l}$ of Flash Mix $\left(20 \mathrm{mM}\right.$ tricine, $1.07 \mathrm{mM}\left(\mathrm{MgCO}_{3}\right)_{4} \mathrm{Mg}(\mathrm{OH})_{2} \cdot 5 \mathrm{H}_{2} \mathrm{O}, 2.67 \mathrm{mM}$ $\mathrm{MgSO}_{4} \cdot 7 \mathrm{H} 2 \mathrm{O}, 0.1 \mathrm{mM} \mathrm{Na} \mathrm{EDTA}_{2} \cdot 2 \mathrm{H}_{2} \mathrm{O}, 2.0 \mathrm{mM}$ DTT, $0.47 \mathrm{mM}$ luciferine, $5.0 \mathrm{mM}$ ATP) into each well. The resulting light production was quantified during $2 \mathrm{sec}$ and then the remaining luciferase activity was quenched by injecting $50 \mu \mathrm{l}$ of $0.2 \mathrm{M} \mathrm{NaOH}$ using the second injector. Light production was expressed as relative light units (RLUs).

\section{Data analysis}

Significance of the induction of reporter gene expression was tested against the vehicle control using Student's t-test. Dose-response curves for induction of reporter protein expression by TCDD were constructed by fitting the data to the one-site ligand binding equation [response $=$ ( maximal response level $\times$ concentration TCDD) / (concentration TCDD $+\mathrm{EC}_{50}$ )] describing a response controlled by binding of ligand to a receptor with one ligand-binding site in relation to ligand concentration.

\section{RESULTS}

\section{Construction and characterization of the DRE-CAFLUX reporter cell line}

A reporter construct analogous to pGudLuc1.1 (Aarts et al., 1995) was generated, carrying an enhanced green-fluorescent protein (EGFP), instead of a firefly luciferase (LUC) reporter gene, under transcriptional control of the same regulatory sequences as applied to generate the AhR-regulated 
luciferase reporter gene cell line DR-CALUX (Aarts et al., 1993; Aarts et al., 1995). This construct was called pMDREegfp1.1 and was stably transfected into rat H4IIE hepatoma cells as described above to produce a dioxin-responsive element (DRE)-mediated AhR-controlled EGFP reporter cell line, to be applied as a Dioxin-Responsive Element-driven Chemical-Activated FLUorescent protein eXpression assay (DRE-CAFLUX) for measuring AhR-mediated biological effects.

The validation of the induction of enhanced green-fluorescent protein (EGFP) expression in DRE-CAFLUX cells as a true AhR-mediated response and the basic comparison to the analogous firefly luciferase-based DR CALUX reporter gene assay has been described elsewhere (Aarts et al., 1998). The major difference between these reporter gene systems is the prolonged reporter protein expression due to the much higher stability of EGFP as compared to luciferase, resulting in intracellular accumulation.

\section{Induction of EGFP expression in DRE-CAFLUX cells by TCDD}

Firstly, DRE-CAFLUX cells were exposed to TCDD. TCDD is a compound that can be considered as a constant inducer because it is very slowly metabolized and due to its persistency should lead to an accumulated signal over time. Indeed, when DRE-CAFLUX cells are exposed to a stable inducer such as TCDD the production of EGFP turns out to be sustained resulting in gradual accumulation of EGFP up to at least 96 hours after exposure start (Fig. 1). The $\mathrm{EC}_{50}$ value observed with different exposure times varies from 9.7 to $24.7 \mathrm{pM}$ TCDD, which is highly comparable with the variation in $\mathrm{EC}_{50}$ found using the DR CALUX' assay, which is on average $15 \mathrm{pM}$ at $24 \mathrm{~h}$ exposure (Murk et al., 1996; Hoogenboom et al., 1999). Moreover, as with the DR CALUX" based on luciferase, the doseresponse relation for induction of the EGFP reporter protein by 24 hours of exposure to TCDD is very accurately described by the 1-site ligand equation describing occupation of a receptor with one ligand-binding site in relation to ligand concentration, and this also holds for the longer exposure times up to 96 hours. Therefore, we conclude that the DRE-CAFLUX and DR CALUX' assays are highly comparable test systems suitable for high throughput screening of (human plasma) samples for AhR agonists. We also determined whether the quantification of AhR agonists in human blood plasma is influenced by the presence of plasma matrix components. A human blood plasma sample was spiked with different concentrations of TCDD and analysed by singular and repeated DRECAFLUX assays. Comparison of the response to the same concentration of TCDD in the presence and absence of plasma, showed neither upon singular, nor upon repeated exposure, a significant difference on the EGFP induction in DRE-CAFLUX cells, except for a higher background level (results not shown).

\section{Induction of EGFP expression in DRE-CAFLUX cells by benzo[a]pyrene}

Fig. 2 shows the difference in response upon exposure to the readily biodegradable AhR agonist benzo $[a]$ pyrene $(\mathrm{BaP})$ in DR CALUX' cells and DRE-CAFLUX cells. Up to a concentration of 100 $\mathrm{nM}$, the response to $\mathrm{BaP}$ is significantly higher after $8 \mathrm{~h}$ than after $24 \mathrm{~h}$ of exposure (Fig. $2 \mathrm{~A}$ ), because $\mathrm{BaP}$ is readily metabolised in H4IIE cells, and the induced luciferase relatively unstable. Above 100 


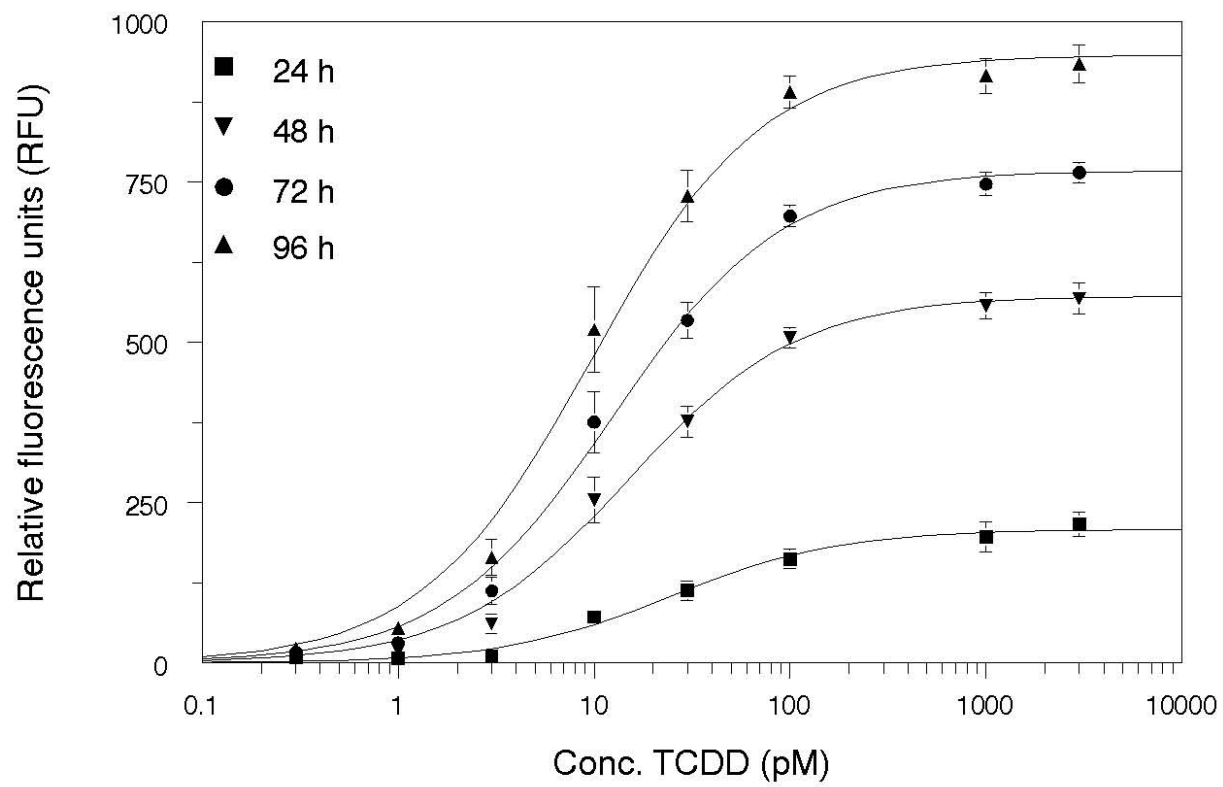

Fig. 1. Dose-response relationship for the induction and accumulation of EGFP in DRE-CAFLUX cells by TCDD. Measurements were performed at $24 \mathrm{~h}(\bullet), 48 \mathrm{~h}(\boldsymbol{\nabla}), 72 \mathrm{~h}(\bullet)$ and $96 \mathrm{~h}(\bullet)$ after single exposures to TCDD. Means of six exposures \pm SD.

$\mathrm{nM}$, the effect is reversed, probably due to saturated kinetics with respect to the metabolism of $\mathrm{BaP}$. However, in the analogous DRE-CAFLUX cells, the EGFP reporter protein induced by exposure to $\mathrm{BaP}$ is stable and the expression level maintained in time (Fig. $2 \mathrm{~B}$ ), although the concentration of $\mathrm{BaP}$ must have decreased likewise after 8 hours of exposure as was observed in the DR CALUX (Fig. 2A), because both reporter cell variants originate from the same H4IIE parent cell strain.

\section{Repeated exposure to benzo[a]pyrene}

Subsequently, we investigated whether repeated exposure to the non-persistent AhR agonist BaP, which would result in repeated transient activation of reporter gene expression, would lead to accumulation of EGFP, and as such in an increased sensitivity of the DRE-CAFLUX assay for BaP as compared to the DR CALUX" (Fig. 3). A second and third exposure to the same concentration of $\mathrm{BaP}, 24$ respectively 48 hours after the first exposure, was each found to result in a further increase in the level of EGFP expression (Fig. 3A). In the DR CALUX, a second exposure 24 hours after the first one, did produce a second pulse of luciferase expression which was clearly detectable 8 hours after the second exposure, but was found to be transient, as expected, and to have disappeared completely, or largely, 24 hours later (Fig. 3B). The higher signals found by DR CALUX after the second exposure are probably caused by the freshly added medium, an unexplained effect seen often in our and others' lab. The detection limit of the DR CALUX' assay, $8 \mathrm{~h}$ after changing the medium, remained at $0.1 \mathrm{nM} \mathrm{BaP}$ (Fig. 3B), so this effect does not seem to decrease the detection limit, for it concerns especially the higher concentrations of $\mathrm{BaP}$. Because the same result was expected 


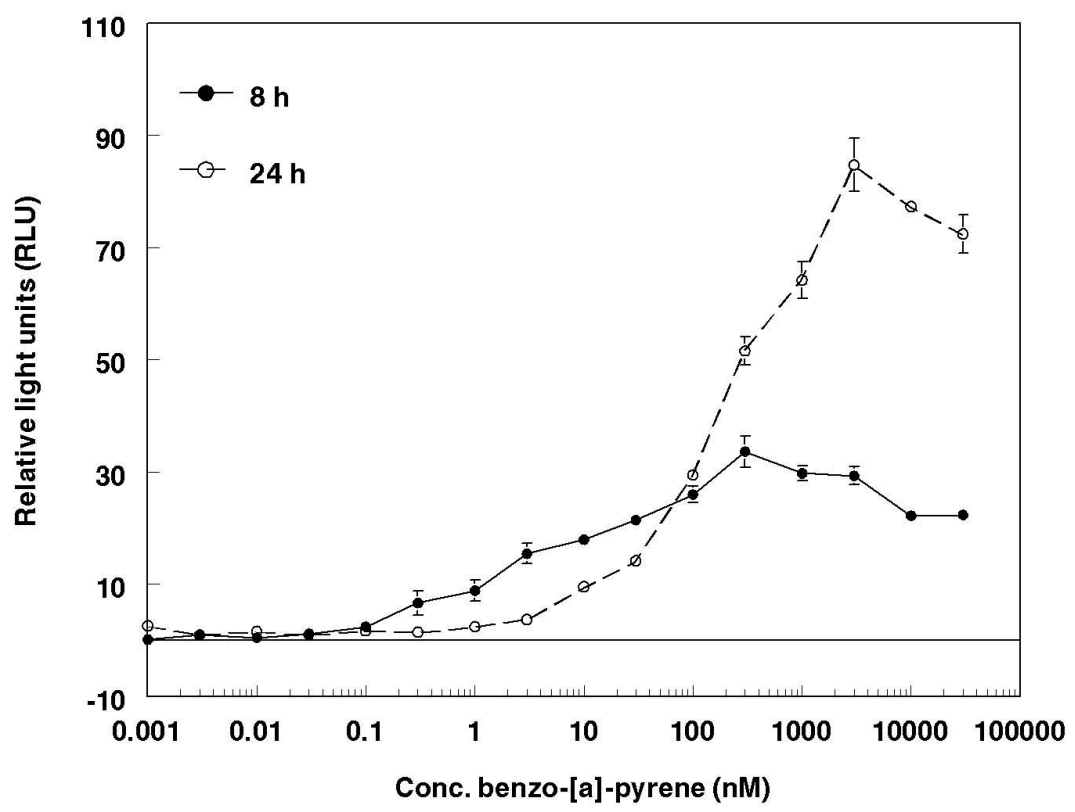

Fig. 2 A

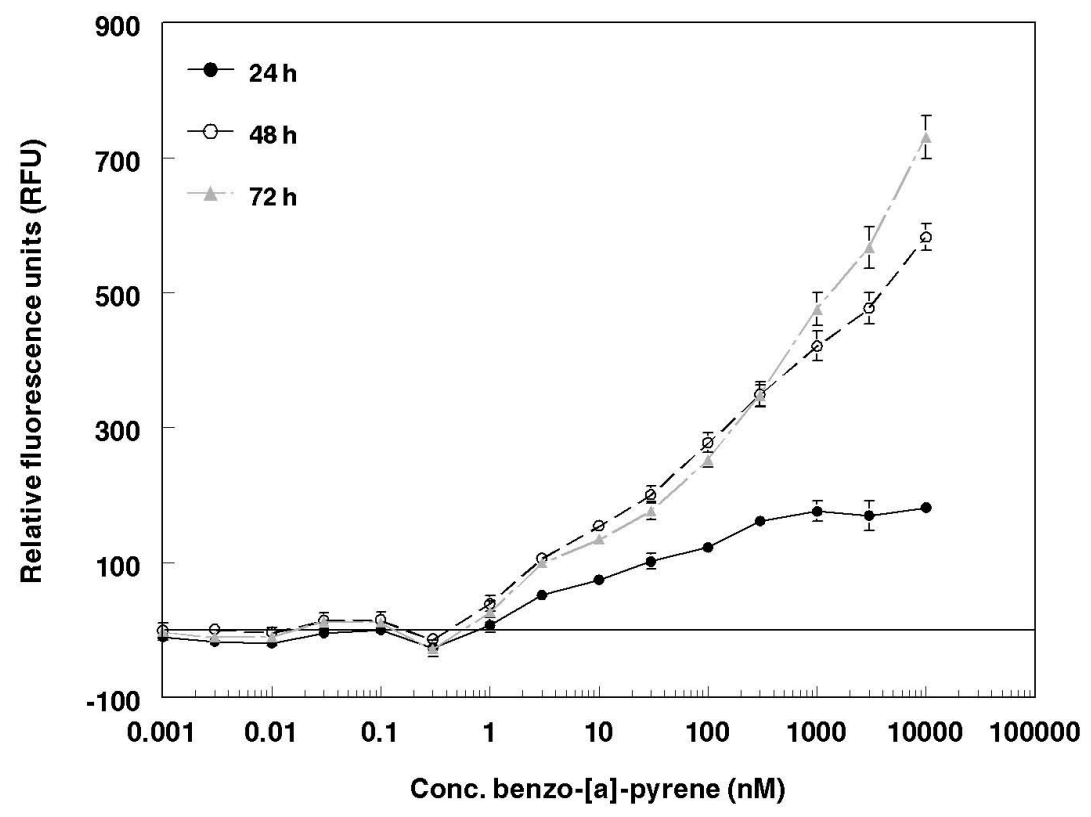

Fig. 2 B

Fig. 2. Time course of the induction by BaP of (A) luciferase expression in DR CALUX ${ }^{\circ}$ cells, and (B) EGFP expression in DRE-CAFLUX cells. Cells were once exposed to samples for $8 \mathrm{~h}(\bullet)$, and $24 \mathrm{~h}\left({ }^{\circ}\right)$ (DR CALUX ${ }^{\star}$ ), and for $24 \mathrm{~h}(\bullet), 48 \mathrm{~h}\left({ }^{\circ}\right)$, and $72 \mathrm{~h}(\bullet)$ (DRE-CAFLUX). Means of triplicate exposures \pm SD. 


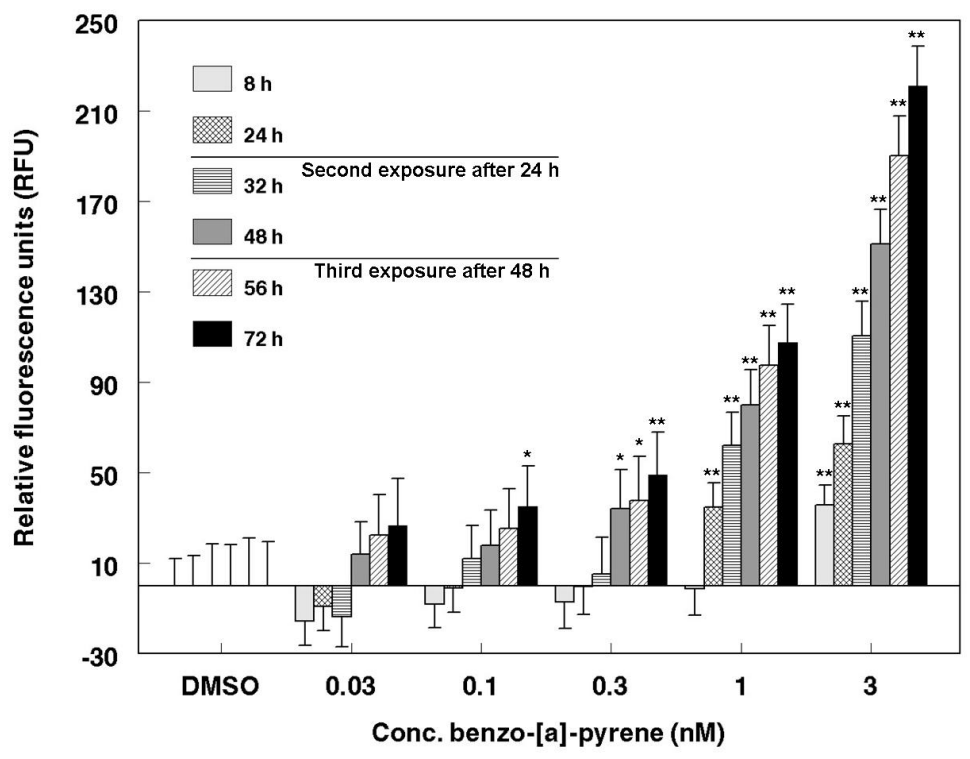

Fig. 3 A

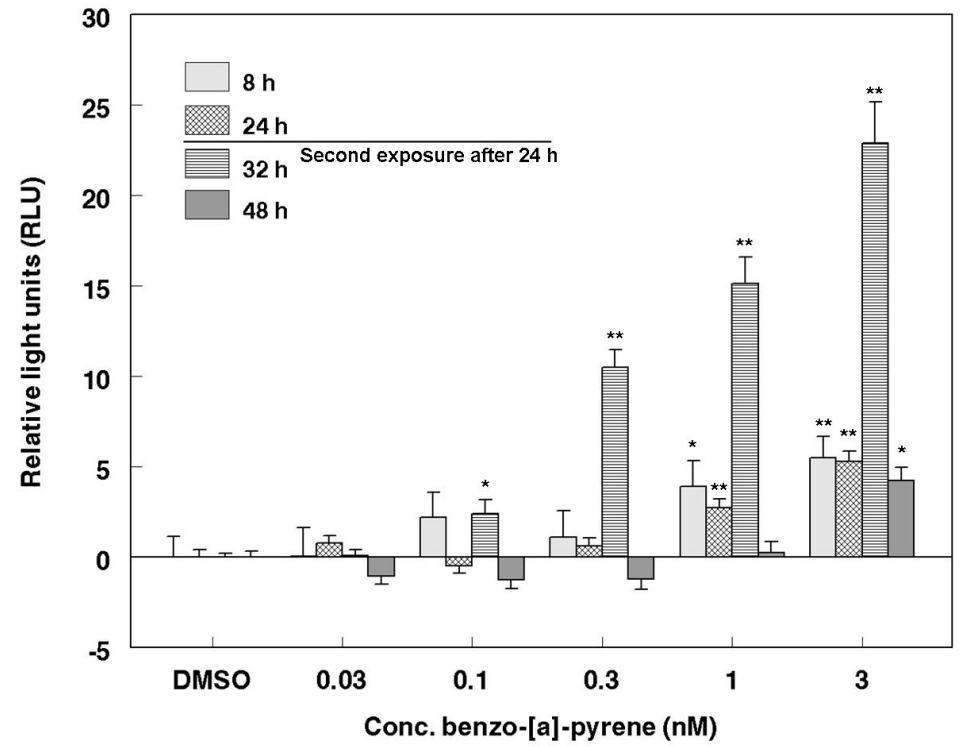

Fig. 3 B

Fig. 3. Response generated by repeated exposure to $0.03-3 \mathrm{nM} \mathrm{BaP}(\mathrm{A})$ in the DRE-CAFLUX, and (B), the DR CALUX ${ }^{\star}$ cell line. Measurements were performed after 8, 24, 32, 48, 56 and $72 \mathrm{~h}$ after the first exposure. Second and third exposures were started respectively $24 \mathrm{~h}$ and $48 \mathrm{~h}$ after the start of the first exposure, after the fluorescence resulting from the previous exposure had been determined at those time points. Data were corrected for the blank DMSO. Means of nine exposures \pm SD. Responses significantly different from background are marked ${ }^{*} \mathrm{p}<0.05$, and ${ }^{* *} \mathrm{p}<0.01$. 
again, the exposure was not repeated a third time at 48 hours in case of the DR CALUX:. In the DRE-CAFLUX the detection limit for BaP (Fig. 3A) decreased with repeated exposure ( $1 \mathrm{nM}, 0.3$ $\mathrm{nM}$, and $0.1 \mathrm{nM}$ for single $(24 \mathrm{~h})$, double $(2 \times 24 \mathrm{~h})$ and triple $(3 \times 24 \mathrm{~h})$ exposure, respectively, and a non-significant but distinct response was observed at $0.03 \mathrm{nM}$ after triple exposure). After a single $24 \mathrm{~h}$ period of exposure the DR CALUX' started to show a non-significant response at $0.3 \mathrm{nM} \mathrm{BaP}$, becoming significant only at higher concentrations of $1 \mathrm{nM}$ and $3 \mathrm{nM} \mathrm{BaP}$ (Fig. 3B), which is similar to the performance observed for the DRE-CAFLUX after a single $24 \mathrm{~h}$ exposure. At time point 32 $\mathrm{h}$ a significant response is observed in the DR-CALUX due to the second exposure already at 0.1 $\mathrm{nM}$ and $0.3 \mathrm{nM} \mathrm{BaP}$, but these responses appear to be transient and therefore present the practical difficulty to catch them the moment of peak induction. When the result is measured at $48 \mathrm{~h}$ when the response has stabilised, the second exposure appears not to have improved the detection limit in the DR CALUX:

\section{DR CALUX in plasma samples from a human intervention study}

AhR agonist activity in human blood plasma samples ( $10 \% \mathrm{v} / \mathrm{v}, 24 \mathrm{~h}$ exposure time) from a food intervention study with AhR agonist-containing vegetables or grapefruit juice was first analysed using the luciferase-based DR CALUX ${ }^{\circledR}$ assay. Using the standard period of 24 hours of exposure, AhR activity turned out to be only marginally detectable by direct measurement of these plasma samples without any extraction and concentration step (Fig. 4). A low induction was measured with responses at the level found for approximately $0.3 \mathrm{pM} \mathrm{TCDD}$, and no differences were seen between blood plasma samples taken before and after the food intervention.

\section{DRE-CAFLUX in plasma samples from a human intervention study}

We tested if the EGFP-based DRE-CAFLUX with repeated exposure would allow direct measurement of AhR agonist activity in the human blood plasma samples from the intervention study with NAhRA-enriched diets with improved sensitivity. Figure 5 shows the response of DRECAFLUX cells after repeated exposure to culture medium with $10 \%$ human plasma sample during three consecutive periods of 24 hours, and EGFP expression being measured 24, 32, 48 and 72 hours after the first exposure. All samples of the intervention with grapefruit juice showed a similar low response at all measured time points (Fig. 5), which was in the range of the response generated by 1 pM TCDD (24 and 32 hours of exposure), or even substantially below that level (48 and 72 hours of exposure). No effect of the intervention was found. However, after $48 \mathrm{~h}$ and a second round of exposure, blood plasma from the intervention with cruciferous vegetables showed a tendency of a higher response $3 \mathrm{~h}$ after the last consumption $(\mathrm{p}=0.11)$, and significantly $(\mathrm{p}=0.04)$ at $24 \mathrm{~h}$ after the last intervention (Fig. $5 \mathrm{C}$ ). After $72 \mathrm{~h}$ and a third round of exposure, the response of the samples taken at $3 \mathrm{~h}(\mathrm{p}=0.08)$ and $24 \mathrm{~h}(\mathrm{p}=0.02)$ after the intervention with cruciferous vegetables was significantly elevated. Using the grapefruit juice intervention as a reference, the effect of the intervention with cruciferous vegetables was even significant after both the second and the third round of exposure (respectively 48 and 72 hours after the first exposure), and this holds for both the 


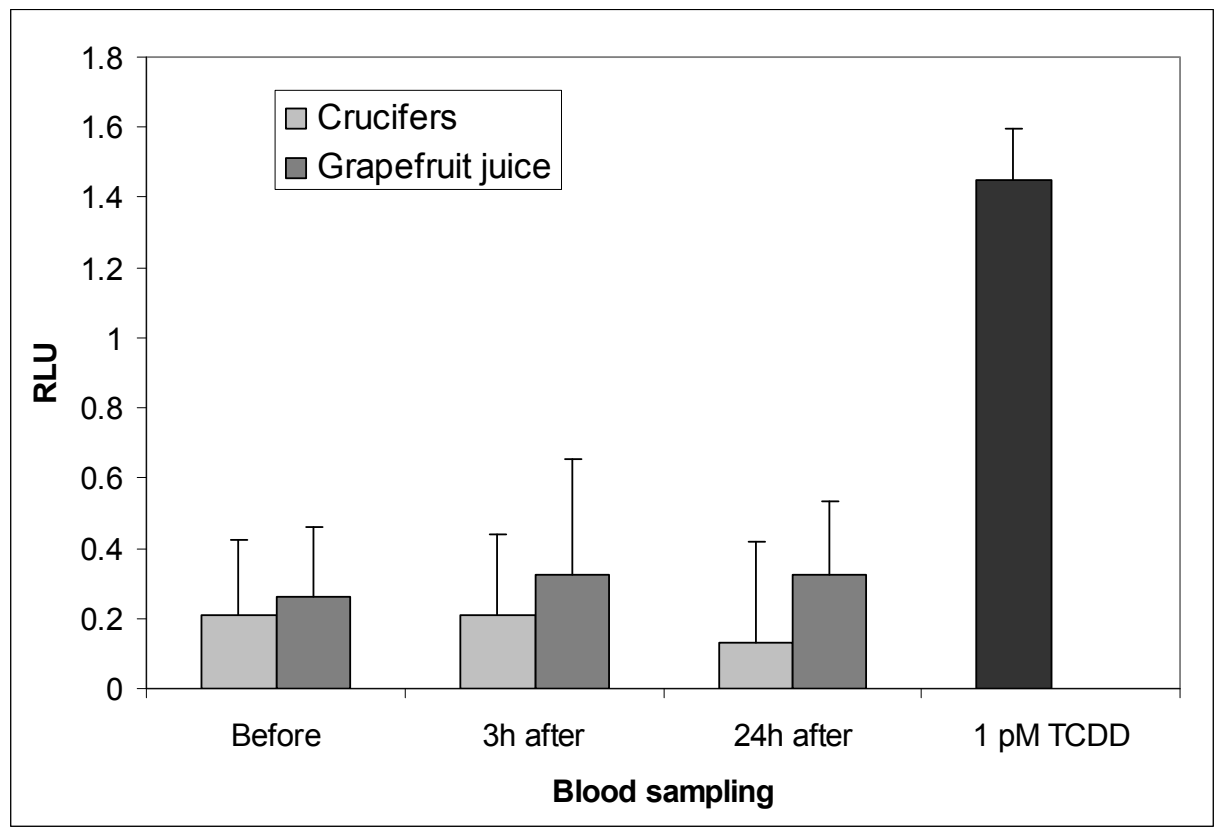

Fig. 4. Luciferase induction in DR CALUX cells after $24 \mathrm{~h}$ exposure to human plasma samples $(10 \% \mathrm{v} / \mathrm{v}$ in medium) from an intervention study with cruciferous vegetables or grapefruit juice. The average of the sample signal minus the mean DMSO control signal from five (cruciferous vegetables) or six (grapefruit juice) study participants \pm SD was plotted. No significant differences were measured between samples from before the intervention and $3 \mathrm{~h}$ or $24 \mathrm{~h}$ after the intervention. The bar of TCDD is shown to indicate the level of the signals.

$3 \mathrm{~h}$ and $24 \mathrm{~h}$ time points (Fig. 5C and 5D). As expected, the response to $1 \mathrm{pM}$ TCDD increased after each extra exposure, but the responses of all plasma samples, except for the $3 \mathrm{~h}$ and $24 \mathrm{~h}$ cruciferous samples, remained as low as the first measurement after $24 \mathrm{~h}$. Also, the response level of all blood samples taken after the intervention with cruciferous vegetables did not increase as much as that of $1 \mathrm{pM}$ TCDD after three consecutive $24 \mathrm{~h}$ periods of exposure, and the response level attained by these blood samples appeared to be about half that level (estimated to correspond to approximately 0.5 pM TCDD).

\section{Discussion}

In this study, we investigated if the DRE-CAFLUX bioassay, which is based on the stable reporter protein enhanced green-fluorescent protein (EGFP), would enable to detect lower concentrations of non-persistent AhR agonists than the DR CALUX' assay, especially when repeated exposures are performed in order to achieve accumulation of EGFP. Because of the great stability of EGFP, repeated exposure increases the signal in the DRE-CAFLUX assay, while there is no such effect in the analogous DR CALUX ${ }^{\circ}$ assay, for its reporter gene encodes the relatively unstable luciferase (Aarts et al., 1998). For use in large human intervention studies concerning AhR-agonist exposure, 


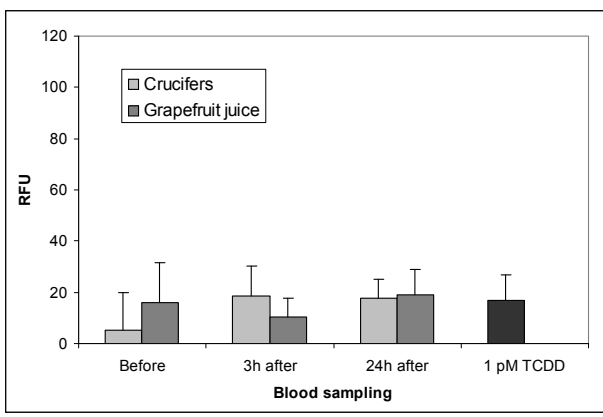

A

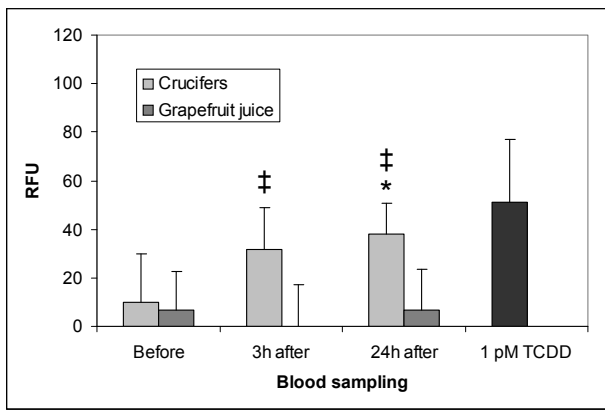

C

Fig. 5. Induced EGFP expression in DRE-CALUX cells after $24 \mathrm{~h}$ (A), $32 \mathrm{~h}$ (B), $48 \mathrm{~h}$ (C) and $72 \mathrm{~h}$ (D) exposure to human plasma samples ( $10 \% \mathrm{v} / \mathrm{v}$ in medium) from an intervention study with cruciferous vegetables or grapefruit juice. A second and third exposure of the DRE-CALUX cells were started immediately after the measurements at $24 \mathrm{~h}$ respectively $48 \mathrm{~h}$ after the start of the first exposure. The average of the sample signal minus the mean DMSO control signal from five (cruciferous vegetables) or six (grapefruit juice) study participants \pm SD was plotted. ${ }^{*}, \mathrm{p}$ $<0.05$ for differences between before and after intervention. $\neq, \neq \neq, p=0.05$, resp. $p=0.01$ for differences between cruciferous vegetables and grapefruit juice interventions.

but also for many other research fields concerning AhR-active components, such as in food and environmental toxicology and in medical research, a sensitive, specific, simple and cheap detection system for AhR-mediated biological effects would offer great advantages.

In a pilot study, we detected by use of the DR CALUX ${ }^{\circ}$ assay marginally elevated levels of AhRactive compounds in human blood plasma samples after a dietary intervention with cruciferous vegetables (de Waard et al., submitted). However, this required relatively large plasma amounts and an extraction and concentration procedure. AhR-activity in blood samples after consumption of cruciferous vegetables was reported by Connor et al., also using an extraction procedure and a reporter gene bioassay based on the mouse hepatoma H1L6.1c3 cell line stably transfected with the dioxin-inducible pGudLuc6.1 reporter plasmid (Connor et al., 2007). In our study, measurements involving direct addition of crude test plasma to the cells up to $15 \% \mathrm{v} / \mathrm{v}$ did not show responses well above the detection limit of the DR CALUX' and did not reveal effects of the intervention (de Waard et al., submitted). Extraction of the samples, however, is costly, time-consuming and may 
compromise the recovery and integrity of the compounds of interest and produce artefacts, since the AhR-agonists we study do originate from natural compounds, and may be unstable (Pohjanvirta et al., 2002).

Our present study with the rapidly metabolised AhR-agonist model compound benzo[a]pyrene (BaP) (Machala et al., 2001) showed indeed, that repeated exposure in the DRE-CAFLUX assay decreased the lowest detectable concentration from $1 \mathrm{nM}$ at $24 \mathrm{~h}$ exposure to $0.1 \mathrm{nM} \mathrm{BaP}$ at $72 \mathrm{~h}$ with two repeated exposures (Fig. 3).

It appears that both for the DR CALUX and DRE-CAFLUX all blood plasma samples show a response just above the detection limit upon a single exposure during 24 hours. However, the samples taken at $3 \mathrm{~h}$ and $24 \mathrm{~h}$ after the intervention with cruciferous vegetables produce an increased response in the DRE-CAFLUX after repeated exposure as compared to the samples taken before the intervention (Fig. 5). This response was statistically significant and estimated to correspond to approximately 0.5 pM TCDD. Also in our previous study we detected a basal response of blood plasma samples from study subjects on an AhR agonist-enriched diet, and in a blank fetal bovine serum sample (de Waard et al., submitted). This low response in the background range was also found by others (N'Guyen et al., 2002), and a possible explanation is that the presence of corticosteroids in the plasma or serum may have a stimulating effect on the reporter assay signal. For instance, the glucocorticoid receptor agonist dexamethasone causes a small response in the DR CALUX assay, but also increases the signal of TCDD significantly (Hoogenboom et al., 1999), possibly by upregulation of the AhR (Sonneveld et al., 2007). However, the increased response observed after repeated exposure to the samples from the crucifer intervention only occurring in the DRE-CAFLUX strongly suggests that this response is due to the unstable NAhRAs originating from the cruciferous vegetables, which are apparently found in an AhR-active form in blood plasma. Cruciferous vegetables contain glucobrassicine, which is converted by the enzyme myrosinase into indole-3-carbinol after crushing of the vegetables. Upon consumption, indole-3-carbinol undergoes self-condensation reactions in the acid environment of the stomach, and some of the reaction products, like indolo[3,2-b]carbazole (Bjeldanes et al., 1991), are well-known AhR-agonists. If a 10\% solution of plasma induces an activity comparable with 0.5 - $1 \mathrm{pM}$ TCDD, the bioactivity in non-diluted blood plasma will be comparable to 5 - $10 \mathrm{pM}$ TCDD. This is near the $\mathrm{EC}_{50}$ in the DR CALUX (Murk et al., 1996) and therefore likely to be sufficiently high to cause considerable AhR-agonistic effects in the human body. The reason why the EGFP-accumulation effect is stronger for TCDD is probably due to the fact that NAhRAs and $\mathrm{BaP}$ are more biodegradable. Another possible explanation is that TCDD accumulates more readily in the cells than the other compounds, and thus more of the previous dose is still remaining during repeated exposure.

The blood plasma samples from the grapefruit juice intervention did not produce a clear response in the DRE-CAFLUX after repeated exposure. As grapefruit contains furanocoumarins, like bergamottin, which can bind to and activate the AhR (Baumgart et al., 2005; Van Ede et al., 2008), increased AhR activity was expected in the blood samples taken after the intervention. Moreover, the calculated amount of TCDD/CALUX-equivalents from NahRAs in grapefruit juice was much 
higher than in the cruciferous vegetables administered in the intervention studies (de Waard et al., submitted). Since grapefruit juice as such is known to display AhR-activating bioactivity in the DR CALUX' assay (De Waard et al., 2008), most of the NAhRAs from the grapefruit juice are apparently metabolized into compounds which do not activate the AhR, before they enter the bloodstream, In conclusion, the DRE-CAFLUX bioassay performed with repeated exposure to the test samples can exceed the DR CALUX' in sensitivity and furthermore is capable of real-time and repeated measurements allowing to take measurements when the response has become optimal, is less critical to the time point the measurements are taken because peaks in reporter gene induction are "memorised", is reasonably fast, and very well amenable to high throughput screening applications for the detection of very low levels of unstable AhR-agonists in blood plasma and other biocompatible complex matrices.

\section{ACKnowledgements}

The study was supported by the Dutch Centre of Human Nutrigenomics (CHN). 


\section{REFERENCES}

Aarts, J. M., Denison, M. S., Cox, M. A., Schalk, M. A., Garrison, P. M., Tullis, K., de Haan, L. H., and Brouwer, A. (1995). Species-specific antagonism of Ah receptor action by 2,2'5,5'-tetrachloro- and 2,2'3,3'4,4'-hexachlorobiphenyl. Eur J Pharmacol 293, 463-474.

Aarts, J. M. M. J. G., Denison, M. S., de Haan, L. H., Schalk, J. A. C., Cox, M. A., and Brouwer, A. (1993). Ah receptor-mediated luciferase expression: a tool for monitoring dioxin-like toxicity. Organohalogen Compounds 13, 361-365.

Aarts, J. M. M. J. G., Jonas, A., van den Dikkenberg, L. C., and Brouwer, A. (1998). CAFLUX, a simplified version of the CALUX assay for Ah receptor (ant)agonists, based on enhanced green fluorescent protein (EGFP) reporter gene expression. Organohalogen Compounds 37, 85-88.

Baird, W. M., Hooven, L. A., and Mahadevan, B. (2005). Carcinogenic polycyclic aromatic hydrocarbon-DNA adducts and mechanism of action. Environ Mol Mutagen 45, 106-114.

Baumgart, A., Schmidt, M., Schmitz, H. J., and Schrenk, D. (2005). Natural furocoumarins as inducers and inhibitors of cytochrome P450 1A1 in rat hepatocytes. Biochem Pharmacol 69, 657-667.

Bjeldanes, L. F., Kim, J. Y., Grose, K. R., Bartholomew, J. C., and Bradfield, C. A. (1991). Aromatic hydrocarbon responsiveness-receptor agonists generated from indole-3-carbinol in vitro and in vivo: comparisons with 2,3,7,8-tetrachlorodibenzo-p-dioxin. Proc Natl Acad Sci U S A 88, 9543-9547.

Chalfie, M., Tu, Y., Euskirchen, G., Ward, W. W., and Prasher, D. C. (1994). Green fluorescent protein as a marker for gene expression. Science 263, 802-805

Connor, K. T., Harris, M. A., Edwards, M. R., Budinsky, R. A., Clark, G. C., Chu, A. C., Finley, B. L., and Rowlands, J. C. (2007). AH receptor agonist activity in human blood measured with a cell-based bioassay: Evidence for naturally occurring AH receptor ligands in vivo. J Expo Science Environ Epidemiol, doi:10.1038/ sj.jes.7500607.

De Waard, W. J., Aarts, J. M. M. J. G., Peijnenburg, A. A. C. M., Baykus, H., Talsma, E., Punt, A., De Kok, T. M. C. M., Van Schooten, F. J., and Hoogenboom, L. A. P. (2008). Gene expression profiling in Caco-2 human colon cells exposed to TCDD, benzo[a]pyrene, and natural Ah receptor agonists from cruciferous vegetables and citrus fruits. Toxicology in Vitro 22, 396-410.

Denison, M. S., and Nagy, S. R. (2003). Activation of the aryl hydrocarbon receptor by structurally diverse exogenous and endogenous chemicals. Annu Rev Pharmacol Toxicol 43, 309-334.

Garrison, P. M., Tullis, K., Aarts, J. M. M. J. G., Brouwer, A., Giesy, J. P., and Denison, M. S. (1996). SpeciesSpecific Recombinant Cell Lines as Bioassay Systems for the Detection of 2,3,7,8-Tetrachlorodibenzo- $p$ dioxin-like Chemicals. Fund. Appl. Toxicol 30, 194-203.

Hankinson, O. (1995). The aryl hydrocarbon receptor complex. Annu Rev Pharmacol Toxicol 35, 307-340.

Hoogenboom, L. A., Hamers, A. R., and Bovee, T. F. (1999). Bioassays for the detection of growth-promoting agents, veterinary drugs and environmental contaminants in food. Analyst 124, 79-85.

Keller, G.-A., Gould, S., DcLuca, M., and Subramani, S. (1987). Firefly luciferase is targeted to peroxisomes in mammalian cells. Proc. Natl. Acad. Sci. USA 84, 3264-3268.

Machala, M., Vondracek, J., Blaha, L., Ciganek, M., and Neca, J. V. (2001). Aryl hydrocarbon receptor-mediated activity of mutagenic polycyclic aromatic hydrocarbons determined using in vitro reporter gene assay. Mutat Res 497, 49-62.

Murk, A. J., Legler, J., Denison, M. S., Giesy, J. P., Van de Guchte, C., and Brouwer, A. (1996). Chemical-activated luciferase expression (CALUX): a novel in vitro bioassay for Ah receptor active compounds in sediments and pore water. Fund. Appl. Toxicol 33, 149-160.

Nagy, S. R., Sanborn, J. R., Hammock, B. D., and Denison, M. S. (2002). Development of a green fluorescent protein-based cell bioassay for the rapid and inexpensive detection and characterization of ah receptor agonists. Toxicol Sci 65, 200-210.

N'Guyen, Q. B., Fallone, F., Seree, E., Fina, F., Villard, P. H., Guigal, N., De Meo, M., Lacarelle, B., Martin, P. M., and Barra, Y. (2002). Serum increases CYP1A1 induction by 3-methylcholanthrene. Biochem Biophys Res Commun 297, 249-254.

Pohjanvirta, R., Korkalainen, M., McGuire, J., Simanainen, U., Juvonen, R., Tuomisto, J. T., Unkila, M., Viluksela, M., Bergman, J., Poellinger, L., and Tuomisto, J. (2002). Comparison of acute toxicities of indolo[3,2-b] carbazole (ICZ) and 2,3,7,8-tetrachlorodibenzo-p-dioxin (TCDD) in TCDD-sensitive rats. Food Chem Toxicol 40, 1023-1032.

Safe, S. (2001). Molecular biology of the Ah receptor and its role in carcinogenesis. Toxicology Letters 120, 1-7. 
Sambrook, J., Fritsch, E. F., and Maniatis, T. (1989). Molecular cloning: A Laboratory Manual. Cold Spring Harbor Laboratory Press.

Sonneveld, E., Jonas, A., Meijer, O. C., Brouwer, A., and van der Burg, B. (2007). Glucocorticoid-enhanced expression of dioxin target genes through regulation of the rat aryl hydrocarbon receptor. Toxicol Sci 99, 455-469.

Thompson, J. F., Hayes, L. s., and Lloyd, D. B. (1991). Modulation of firefly luciferase stability and impact on studies of gene regulation. Gene 103, 171-177.

Van Ede, K., Li, A., Antunes-Fernandes, E., Mulder, P., Peijnenburg, A.A.C.M., Hoogenboom, L.A.P. (2008). Bioassay directed identification of natural aryl hydrocarbon-receptor agonists in marmalade. Analytica Chimica Acta 617, 238-245.6 



\title{
6
}

\section{Influence of TCDD and natural Ah receptor agonists on benzo[ $[a]$ pyrene-DNA adduct formation in the Caco-2 human colon cell line}

\author{
Pim W.J. de Waard ${ }^{\text {a }}$, Theo M.C.M. de Kok ${ }^{\text {, }}$ \\ Lou M. Maas a , Ad A.C.M. Peijnenburg ${ }^{\text {b }}$, Ron L.A.P. Hoogenboom ${ }^{\text {, }}$, \\ Jac M.M.J.G. Aarts ${ }^{c}$, Frederik-Jan van Schooten ${ }^{\text {a }}$
}

\footnotetext{
a Department of Health Risk Analysis and Toxicology, Maastricht University, PO box 616, 6200 MD Maastricht, The Netherlands; ${ }^{\mathrm{b}}$ Toxicology \& Effect Monitoring Group, RIKILT Institute of Food Safety, PO box 230, 6700 EA Wageningen, The Netherlands; ${ }^{\mathrm{c}}$ Division of Toxicology, Wageningen University, PO box 8000, 6700 EA Wageningen, The Netherlands
} 


\section{Abstract}

Several compounds originating from cruciferous vegetables and citrus fruits bind to, and activate the aryl hydrocarbon receptor (AhR). This receptor plays an important role in the toxicity of the known tumour promoter and potent AhR-agonist 2,3,7,8-tetrachlorodibenzo- $p$-dioxin (TCDD). However, vegetables and fruits are generally considered as healthy. Therefore, besides the AhRactivation, the natural AhR agonists (NAhRAs) are assumed to show other health concerning effects. AhR-activation induces several cytochrome P450 phase I enzymes involved e.g. in the bioactivation of carcinogenic polycyclic aromatic hydrocarbons (PAHs), like benzo[a]pyrene (BaP), and may as such stimulate DNA-adduct formation of those compounds. Therefore, the influence of TCDD, indolo[3,2-b]carbazole (ICZ, a NAhRA originating from cruciferous vegetables) and a NAhRA-containing extract of grapefruit juice (GJE) on BaP-DNA adduct formation in the human Caco-2 cell line was studied. Also we investigated if different effects of TCDD, ICZ and GJE on adduct formation could be related to the modulation of transcription of biotransformation- and DNA-repair enzymes. Co-exposure to high AhR-activating concentrations of both TCDD and ICZ significantly reduced the amount of BaP-DNA adducts at $0.1 \mu \mathrm{M} \mathrm{BaP}$, while at higher concentrations of $\mathrm{BaP}$ no influence was observed. In contrast, exposure to $0.1 \mu \mathrm{M} \mathrm{BaP}$ combined with GJE showed a significant increase in BaP-DNA adducts, and a significant decrease at 0.3 and $1 \mu \mathrm{M}$ BaP. These differences could not be related to transcription of the phase I and II enzymes CYP1A1, CYP1B1, NQO1, GSTP1 and UGT1A6, nor to transcription of the nucleotide excision repair (NER) enzymes ERCC1, XPA, XPC, XPF and XPG. We conclude that ICZ showed a similar effect on BaP-DNA adduct formation than TCDD, while GJE influenced the adduct formation in a different way. The difference in the influence on adduct formation may be due to effects at the level of enzyme activity, rather than gene expression. 


\section{INTRODUCTION}

Cruciferous vegetables and citrus fruits have been shown to contain significant amounts of compounds that can act as natural aryl hydrocarbon receptor (AhR) agonists (NAhRAs) (Hoogenboom, 2002; Denison and Nagy, 2003; Jeuken et al., 2003). Binding of an agonist to the AhR activates it as a transcription factor, which is considered the main pathway by which dioxins, like 2,3,7,8-tetrachlorodibenzo-p-dioxin (TCDD) exert their toxicity (Hankinson, 1995; Mimura and Fujii-Kuriyama, 2003; Steenland et al., 2004). Nevertheless, NAhRA-containing vegetables and fruits were reported to possess several health promoting properties, including cancer-preventive potential (Steinmetz and Potter, 1996; Verhoeven et al., 1996; Heber, 2004; Yu et al., 2005), although not all epidemiological studies are consistent in this respect (Verhoeven et al., 1996; van Gils et al., 2005; Lynn et al., 2006). Benzo[a]pyrene (BaP), a well known carcinogenic compound originating from incomplete combustion of organic material, for instance by cigarette smoking, is also an AhR agonist. Phase I biotransformation enzymes like the P450 cytochromes CYP1A1 and CYP1B1 can convert $\mathrm{BaP}$ into reactive epoxide metabolites, and in the presence of epoxide hydrolase activity also dihydrodiol epoxides are formed. These electrophilic compounds can bind to the DNA and form BaP-DNA adducts, which can cause mutations, and finally may lead to cancer (Baird et al., 2005; Rundle, 2006). Several detoxifying mechanisms in the cell may prevent these injurious effects; Phase II biotransformation enzymes such as glutathione-S-transferase transform the electrophilic compounds into products which can be eliminated rapidly from the cell, and DNA repair enzymes, like the nucleotide excision repair (NER) system, can remove the bulky BaP-DNA adducts from the DNA (Hanawalt et al., 2003; Baird et al., 2005). Thus there appears to be a dynamic balance between these possible metabolic routes of BaP. Since both TCDD and NAhRAs activate the AhR, they theoretically can stimulate the BaP-DNA adduct formation by induction of CYP1A1 and CYP1B1. It has indeed been reported that TCDD can promote the BaP-adduct formation by AhR activation in rats (Harrigan et al., 2004), and that mice lacking the AhR did not suffer from BaP carcinogenicity (Shimizu et al., 2000).

In this study, we investigated the influence of NAhRAs on BaP-DNA adduct formation in a human colon cancer cell line, and compared it with the effects of TCDD. The Caco-2 cell line was chosen since it is generally used as a model system to study the effect and absorption of compounds in the small intestine, and it's known to show AhR-activity and BaP-DNA adduct formation (Shah et al., 2006). We examined the pure NAhRA indolo[3,2-b]carbazole, a metabolite from cruciferous vegetables, and a hexane extract of grapefruit juice, containing the suspected NAhRAs bergamottin and certain polymethoxy flavones (Canivenc-Lavier et al., 1996; Baumgart et al., 2005; De Waard et al., 2007). Based on the above mentioned tumour-promoting effects of TCDD on the one hand, and the health-protective properties of vegetables and fruits on the other hand, we hypothesized that addition of TCDD to cells exposed to BaP will show an increase in BaP-DNA adduct formation, while addition of NAhRAs will result in a decrease in BaP-DNA adduct formation. The influence on adduct formation was subsequently related to the effects on bioactivation, elimination and DNA- 
repair as examined at the transcription level by measuring mRNA of phase I and II enzymes and NER enzymes.

\section{MATERIALS AND METHODS}

\section{Chemicals}

Methanol, ethanol, n-hexane, diethyl ether, DMSO, $\mathrm{NaCl}$, EDTA, isoamylalcohol, sodiumacetate, $\mathrm{NaH}_{2} \mathrm{PO}_{4}$, formic acid and $\mathrm{LiOH}$ were purchased from Merck (Darmstadt, Germany), phenol, tris, endonuclease, spleen phosphodiesterase and urea from Sigma-Aldrich (Steinheim, Germany), fetal bovine serum, penicillin/streptomycin and trypsin from GIBCO (Paisley, UK), SDS, nuclease P1, $\left[\gamma^{-32} \mathrm{P}\right]$-ATP and $\mathrm{LiCl}$ from MP Biomedicals (Irvine, California, USA), chloroform from Biosolve (Valkenswaard, The Netherlands) and T4 polynucleotide kinase from Fermentas (Hanover, USA). ICZ (purity >95\%) was synthesized as described by Bergman (Bergman, 1970) and checked for quality by HPLC, NMR, IR and MS, using a reference sample which was a kind gift of prof. J. Bergman, Department of Chemistry, Royal Institute of Technology, and Department of Biosciences at Novum, Huddinge, Sweden).

\section{Preparation of the grapefruit juice extract}

Ten $\mathrm{ml}$ of grapefruit juice, obtained from the local supermarket, was mixed with $20 \mathrm{ml}$ of methanol/ water $85 / 15$, and extracted twice with $20 \mathrm{ml}$ of n-hexane/diethyl ether $97 / 3$ by mixing for $1 \mathrm{~h}$. Hexane-layers were collected, evaporated and the residue dissolved in $40 \mu \mathrm{l}$ of DMSO for analysis. In a recent study (De Waard et al., 2007) the grapefruit juice extract (GJE) was analysed by HPLC and found to contain a mixture of suspected NAhRAs, like polymethoxy flavones and a furocoumarin. The grapefruit juice extract contained the polymethoxy flavones tangeretin $(48.5 \mu \mathrm{M})$, sinensetin $(3.7 \mu \mathrm{M})$, tetramethylscutellarein, nobiletin and heptamethoxyflavone (all three $<0.1 \mu \mathrm{M}$ ), and the furocoumarin bergamottin $(4150 \mu \mathrm{M})$. Because bergamottin showed the highest concentration, we express in this study the amount of extract as $\mu \mathrm{M}$ bergamottin. Also a blank extraction with $10 \mathrm{ml}$ water has been performed.

\section{Cell culture and exposure}

The Caco-2 human colorectal adenocarcinoma cell-line (ATCC, Manassas, USA) was grown in DMEM (Sigma, St-Louis, USA), containing 10\% fetal bovine serum and 1\% penicillin/streptomycin, at $37^{\circ} \mathrm{C}$ and $5 \% \mathrm{CO}_{2}$. Cells were seeded $24 \mathrm{~h}$ before exposure in 6 -well plates $\left(5.10^{5}\right.$ cells/well) and exposed for $24 \mathrm{~h}$ to sample solutions in DMSO added to the culture medium. Concentration ranges were made of 1.5-1500 pM TCDD (purity 98\%, Schmidt BV, Amsterdam, The Netherlands), 1-1000 nM ICZ, 0.008-25 $\mu \mathrm{M}$ benzo[a]pyrene (purity >98\%, Aldrich, Steinheim, Germany), and 0.03-6.9 $\mu \mathrm{M}$ bergamottin in grapefruit juice extract for the CYP1A1 mRNA induction experiments. For the adduct analysis, cells were exposed to 0.1 (duplicate), 0.3 or $1 \mu \mathrm{M} \mathrm{BaP}$ (triplicate) together with a very low, low or high AhR-activating concentration of TCDD, ICZ or GJE. In two additional experiments, $0.1 \mu \mathrm{M} \mathrm{BaP}$ was added $6 \mathrm{~h}$ (duplicate), or $0.3 \mu \mathrm{M} \mathrm{BaP}$ was added $15 \mathrm{~h}$ (triplicate) after 
treatment with TCDD, ICZ and GJE, to investigate if pre-treatment with a CYP1A1 inducer could result in a more pronounced effect. The final concentration of DMSO in all exposures was $0.5 \%$ $(\mathrm{v} / \mathrm{v})$. Cytotoxicity of the mixtures was evaluated using the MTT-colorimetric assay according to Mosmann (Mosmann, 1983), with modifications as described previously (Borm et al., 1997).The number of replicates was four.

\section{RNA and DNA isolation}

After exposure total RNA was isolated from the cells using Trizol (Invitrogen, Breda, The Netherlands) according to the manufacturer's protocol. Purity and integrity of the RNA were checked by UV-absorption and gel electrophoresis, respectively. For DNA isolation, cells were washed twice with ice-cold PBS, trypsinized and suspended in $1 \mathrm{ml}$ medium. After centrifugation (1 min, $1500 \mathrm{rpm}$ ) liquid was removed and cells were incubated with $400 \mu \mathrm{l}$ SET/SDS (100 mM NaCl, $20 \mathrm{mM}$ EDTA, $50 \mathrm{mM}$ Tris, $0.5 \% \mathrm{SDS}, \mathrm{pH} 8.0$ ) for $2 \mathrm{~h}$ at $37^{\circ} \mathrm{C}$, followed by treatment with RNAse $\mathrm{A} / \mathrm{T} 1$ and proteinase K (DNAse-free, Boehringer Mannheim). The DNA was purified by phenol/ chloroform/isoamylalcohol (25:24:1) extraction and precipitation with $3 \mathrm{M}$ sodiumacetate $\mathrm{pH}=5.2$, and $100 \%$ ethanol. After washing with $70 \%$ ethanol (v/v) the DNA was dried under a mild nitrogen flow and dissolved in $2 \mathrm{mM}$ Tris ( $\mathrm{pH}$ 7.4). Concentration and purity of the DNA were determined spectroscopically at 230,260 , and $280 \mathrm{~nm}$.

\section{Quantitative Real-time RT-PCR}

One $\mu \mathrm{g}$ of total RNA was reverse transcribed into cDNA using iScript ${ }^{\mathrm{TM}} \mathrm{cDNA}$ Synthesis Kit (BioRad, Hercules, CA, USA) in a final volume of $20 \mu$ l. Table 1 lists the primer sequences used. $\beta$-Actin was used to normalize for differences in RNA input and efficiency during the reverse transcription. Samples were diluted 15 times and duplicates were mixed with primers and $\mathrm{iQ}^{\mathrm{TM}}$ SYBR Green Supermix (Bio-Rad, Hercules, CA, USA) and amplification took place in an iCycler PCR machine with a MyiQ Single Color Real-Time PCR Detector System (Bio-Rad, Veenendaal, The Netherlands). The specificity of the PCR products was checked by melt curve peak analysis and

Table 1. Primer sequences used for quantitative real-time PCR measurements.

\begin{tabular}{|c|c|c|}
\hline Gene & Forward primer $\left(5^{\prime} \rightarrow 3^{\prime}\right)$ & Reverse primer $\left(5^{\prime} \rightarrow 3^{\prime}\right)$ \\
\hline$\beta$-actin & CCT GGC ACC CAG CAC AAT & GCC GAT CCA CAC GGA GTA CT \\
\hline CYP1A1 & TCC TGG AGA CCT TCC GAC ACT & CTT TCA AAC TTG TGT CTC TTG TTG T \\
\hline CYP1B1 & AGT GCA GGC AGA ATT GGA TCA & GCG CAT GGC TTC ATA AAG GA \\
\hline GSTP1 & TGC AAA TAC ATC TCC CTC ATC TAC A & CGG GCA GTG CCT TCA CAT \\
\hline UGT1A6 & GGA ACC CGA CCA TCG AAT C & TCG GGT GAC CAA GCA GAT C \\
\hline NQO1 & GGT GGA GTC GGA CCT CTA TGC & CCT TCA GTT TAC CTG TGA TGT CCT T \\
\hline ERCC1 & ACC CCT CGA CGA GGA TGA G & CAG TGG GAA GGC TCT GTG TAG A \\
\hline XPA & CCG ACA GGA AAA CCG AGA AA & TTC CAC ACG CTG CTT CTT ACT G \\
\hline XPC & CCC AGC CCG CTT TAC CA & TGC ATT AAC TGT AAA TGT TCC AAT GA \\
\hline XPF (ERCC4) & CAC CTC CCT CGC CGT GTA & CGC AAA TAT AAC ACC ACC TTG \\
\hline XPG (ERCC5) & GCA TGA AAT CTT GAC TGA TAT GAA AGA & TAA GCA AGC CTT TGA GTT GGT ACT G \\
\hline
\end{tabular}


by gel electrophoresis. Gene expression levels were calculated from the threshold cycle values and normalised by calculating the ratio with the $\beta$-actin expression level.

\section{${ }^{32}$ P-Postlabeling of BaP-DNA Adducts}

The ${ }^{32} \mathrm{P}$-postlabeling assay for BaP-DNA adducts was performed as described earlier (Van Schooten et al., 2004). In short, $10 \mu \mathrm{g}$ DNA was digested into deoxyribonucleoside 3'-monophosphates by incubation with micrococcal endonuclease and spleen phosphodiesterase for $4 \mathrm{~h}$ at $37^{\circ} \mathrm{C} .75 \%$ of the digest was treated with nuclease $\mathrm{P} 1$ for $30 \mathrm{~min}$ at $37^{\circ} \mathrm{C}$ and the reaction was terminated by adding $0.5 \mathrm{M}$ Tris. The labeling was performed by using $\left[\gamma^{-32} \mathrm{P}\right]$-ATP $(50 \mu \mathrm{Ci})$ in the presence of $\mathrm{T} 4$ polynucleotide kinase for $30 \mathrm{~min}$ at $37^{\circ} \mathrm{C}$, followed by 2-dimensional chromatography using polyethylene-imine cellulose-sheets (Macherey Nagel, Düren, Germany) using the following solvent systems: $\mathrm{S} 1,1 \mathrm{M} \mathrm{NaH}_{2} \mathrm{PO}_{4}$ (pH 6.5); S2, 5.3 M lithium formate $8.5 \mathrm{M}$ urea (pH 3.5); S3, $1.2 \mathrm{M}$ lithium chloride, $0.5 \mathrm{M}$ Tris, $8.5 \mathrm{M}$ urea ( $\mathrm{pH}$ 8.0); $\mathrm{S} 4,1.7 \mathrm{M} \mathrm{NaH}_{2} \mathrm{PO}_{4}$ ( $\mathrm{pH}$ 6.0). For calibration, three standards of $\left[{ }^{3} \mathrm{H}\right]$-BaP-diol-epoxide modified DNA with known modification levels ( 1 per 10 $0^{6}, 10^{7}$ and $10^{8}$ nucleotides) were run in parallel in each experiment. Quantification was performed using a PhosphorImager (Raytest-Fujifilm FLA-3000, Germany) with a detection limit of 1 adduct/10 nucleotides. The other $25 \%$ of the digest was used for the determination of the amount of normal nucleotides by HPLC using UV-detection.

\section{Statistics}

Differences in DNA-adduct levels and gene expression levels were statistically evaluated using the Student's t-test.

\section{RESULTS}

\section{CYP1A1 and CYP1B1 mRNA induction}

To estimate the onset and progress of the AhR response in Caco-2 cells, different exposure times and concentration ranges have been applied for TCDD, BaP, ICZ and GJE and the amount of mRNA of CYP1A1 was measured by use of quantitative RT-PCR (Fig. 1). Exposure to TCDD resulted in increased gene expression in the low picomolar range and a maximum of about 400 fold change in mRNA amount was reached after $15 \mathrm{~h}$ of incubation with $1.5 \mathrm{nM}$. Six h of exposure showed a considerable lower induction of CYP1A1 mRNA. BaP induced CYP1A1 in a comparable way as TCDD, however at concentrations a thousand times higher (Fig. 1A). The maximum induction of CYP1A1 by ICZ and GJE was about a 100 fold change, both after 15 and 24 h. The effective concentration of ICZ was in the same range as of $\mathrm{BaP}$, and GJE, expressed as $\mu \mathrm{M}$ bergamottin, induced CYP1A1 to the same level in a concentration range about a factor 10 higher (Fig. 1B). CYP1B1 mRNA determination resulted in similar induction properties of the samples, although the maximum levels were much lower (10-30 fold change, results not shown). The extraction procedure blank (water subjected to the extraction procedure applied to extract the grapefruit juice) did not induce CYP1A1 or CYP1B1 mRNA significantly (results not shown). 


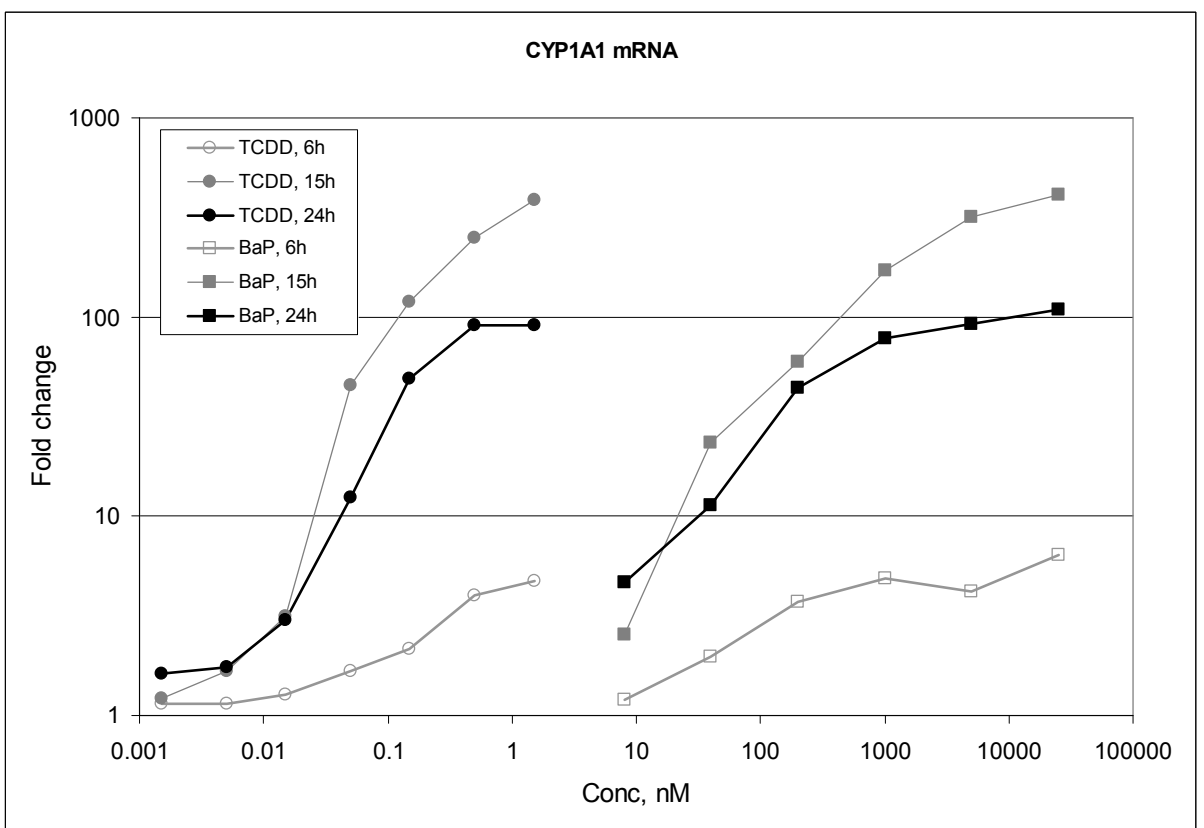

Fig. 1 A

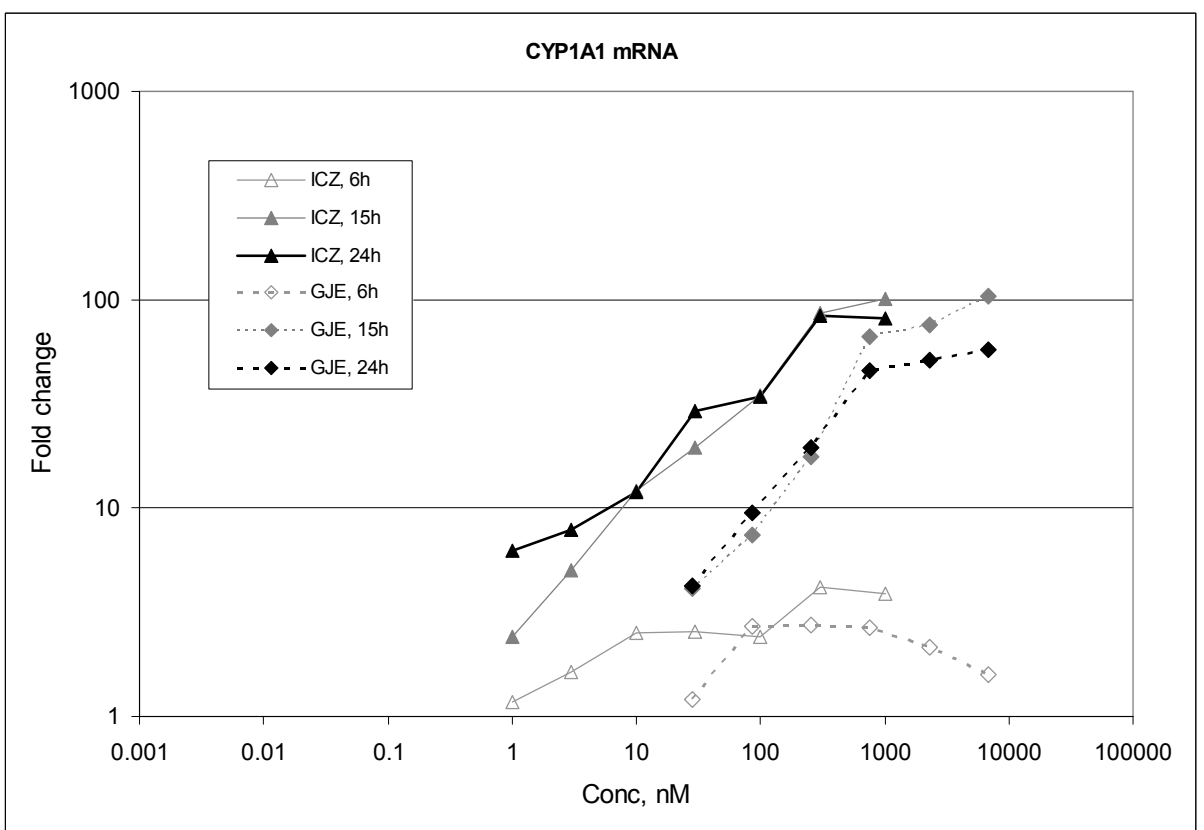

\section{Fig. 1 B}

Fig. 1. Dose-response curves for CYP1A1 mRNA induction in human Caco-2 cells upon 24 h of exposure to TCDD and BaP (A), and to ICZ and GJE (B). CYP1A1 mRNA was measured by Q-RT-PCR. Means of duplicate measurements. ICZ, indolo[3,2-b]carbazole; GJE, grapefruit juice extract. 
The concentrations chosen for BaP, TCDD, ICZ and GJE in the following studies were based on the level of induction of CYP1A1mRNA after 24h of exposure, a marker for AhR-activation. Based on figure $1 \mathrm{~A}$, we estimated a low, medium and high effective concentration of $\mathrm{BaP}$ and a low and high effective concentration for TCDD, ICZ and GJE. Low is defined as around $10 \%$ of the maximum activation, and high is the maximum activation.

\section{BaP-DNA adducts}

In order to determine the effects of TCDD and NAhRAs on the DNA-adduct formation by BaP, human Caco-2 cells were exposed to $\mathrm{BaP}$ in combination with TCDD or NAhRAs, and the adduct formation was measured by ${ }^{32} \mathrm{P}$-postlabelling (Fig. 2). Exposure to $0.1,0.3$ and $1 \mu \mathrm{M}$ BaP resulted in a dose-dependent formation of DNA-adducts of resp. 3.7, 38, and 244 adducts/10E8 nucleotides. Two concentration levels of TCDD and NAhRAs were tested, resulting in either a relatively high or low level of AhR-activation, as judged from the CYP1A gene expression (Fig. 1A). The concentration of TCDD producing a high level of CYP1A1 gene expression (500 pM) showed nearly a four-fold decrease in BaP-DNA adduct formation $(\mathrm{P}=0.11, \mathrm{n}=2)$, but only at the lowest concentration of $\mathrm{BaP}$ tested $(0.1 \mu \mathrm{M})$ (Fig. $2 \mathrm{~A})$. The low $15 \mathrm{pM}$ TCDD concentration reduced the adduct formation significantly to $64 \%$ at $1 \mu \mathrm{M} \mathrm{BaP}$, but had no significant effect at 0.1 and $0.3 \mu \mathrm{M} \mathrm{BaP}$. Both the low and high concentration of ICZ caused a strong reduction of BaP-DNA adduct levels (100 nM ICZ: P $=0.11, \mathrm{n}=2$ ), down to one third of the adducts induced by $0.1 \mu \mathrm{M} \mathrm{BaP}$, but, like TCDD, ICZ showed no effect at the higher concentrations of $\mathrm{BaP}$ (Fig. 2B), with the exception of a small but significant increase at $0.3 \mu \mathrm{M}$ BaP. In contrast with TCDD and ICZ, both concentrations of GJE showed an approximately two-fold increase in adduct formation at $0.1 \mu \mathrm{M} \mathrm{BaP}$ (Fig. 2C). However, both at 0.3 and $1 \mu \mathrm{M} \mathrm{BaP}$, the highest concentration of GJE decreased the amount of adducts significantly by five times (Fig. 2C). TCDD, ICZ and GJE without co-exposure with BaP, just as the solvent DMSO had no effect on DNA adduct formation (results not shown).

We also tested whether pre-treatment with a CYP1A1 inducer would produce a more pronounced effect on BaP-DNA adduct formation as compared to simultaneous exposure. Overall, both after 6 $\mathrm{h}(0.1 \mu \mathrm{M} \mathrm{BaP})$ and $15 \mathrm{~h}(0.3 \mu \mathrm{M} \mathrm{BaP})$ of pre-treatment of the cells with TCDD or NAhRAs, the adduct levels induced by $\mathrm{BaP}$ were not significantly different from those induced by simultaneous exposure to these compounds (results not shown). The only small, but statistically significant, difference was observed between simultaneous incubation with $0.3 \mu \mathrm{M} \mathrm{BaP}$ and $100 \mathrm{nM} \mathrm{ICZ}$ and $15 \mathrm{~h}$ pre-incubation with $100 \mathrm{nM} \mathrm{ICZ}$ followed by simultaneous incubation. Overall, this indicates that a 6 to $15 \mathrm{~h}$ earlier onset of AhR-induction does not produce a more pronounced effect on adduct formation.

For statistical purpose, and because the pre-incubation step was found to have mostly no significant effect at all, the results of the duplicate experiments with $0.1 \mu \mathrm{M}$ BaP simultaneously exposed with (N)AhRAs, and with $6 \mathrm{~h}$ pre-incubation with $(\mathrm{N})$ AhRAs were pooled to obtain $\mathrm{n}=4$. In this way, the decrease in BaP-DNA adduct formation by 500 pM TCDD $(\mathrm{P}<0.05), 3 \mathrm{nM} \mathrm{ICZ}(\mathrm{P}<0.05)$ and 100 


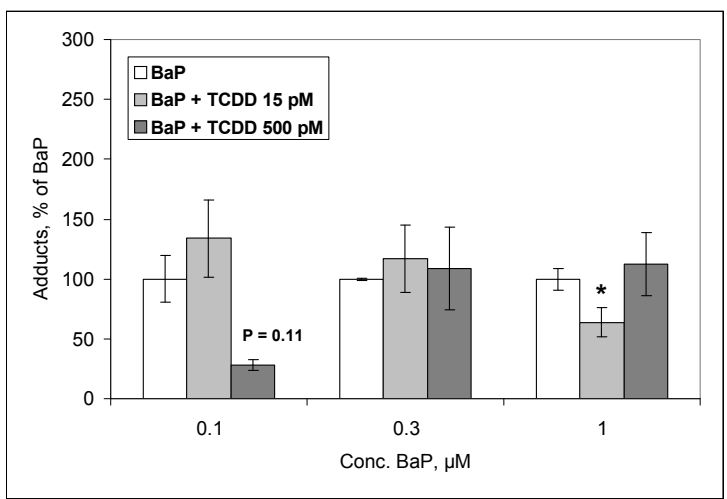

Fig. 2 A

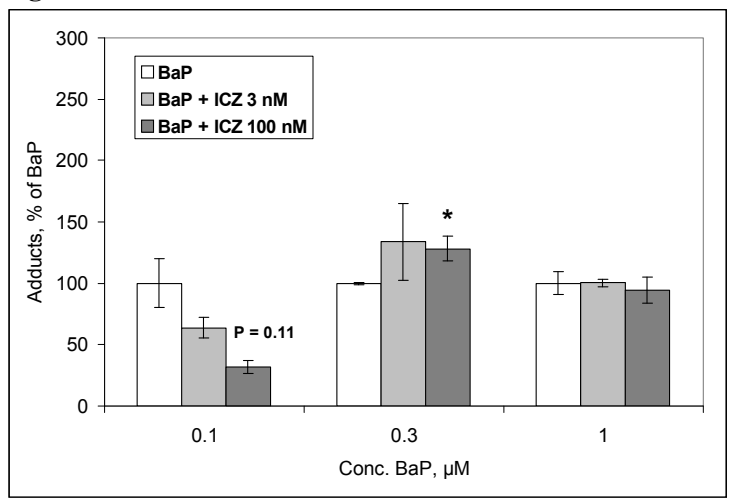

Fig. 2 B

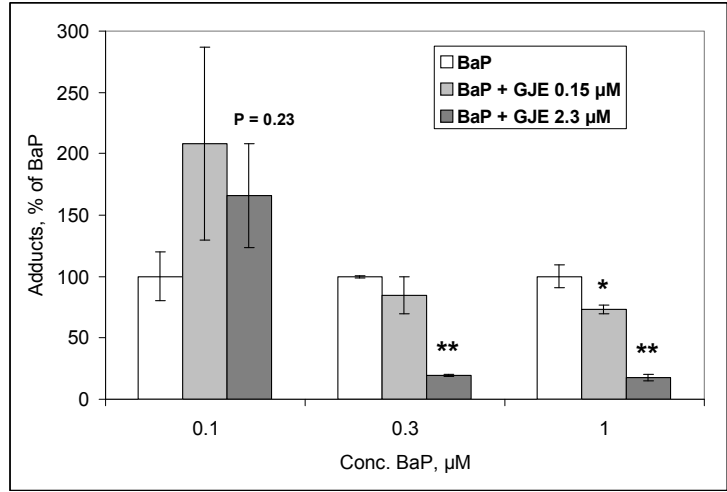

Fig. 2 C

Fig. 2. BaP-DNA adduct formation as measured by ${ }^{32} \mathrm{P}$-postlabelling in Caco-2 cells after combined $24 \mathrm{~h}$ exposure to $\mathrm{BaP}$ with TCDD (A), ICZ (B) or GJE (C). White, exposure to BaP alone (0.1 $\mu \mathrm{M} \mathrm{BaP}$ shows 3.7 adducts/10E8 nucleotides, $0.3 \mu \mathrm{M} \mathrm{BaP}$ shows 38 adducts/10E8 nucleotides, and $1 \mu \mathrm{M} \mathrm{BaP}$ shows 244 adducts/10E8 nucleotides), light grey, $\mathrm{BaP}$ with low concentration of (N)AhRA, dark grey, $\mathrm{BaP}$ with high concentration of (N)AhRA. Means of duplicate $(0.1 \mu \mathrm{M} \mathrm{BaP})$ or triplicate exposures $\pm \mathrm{SD},{ }^{*} \mathrm{P}<0.05$ and ${ }^{* *} \mathrm{P}<0.01$ for the difference between combined exposure and $\mathrm{BaP}$ alone. ICZ, indolo[3,2-b]carbazole; GJE, grapefruit juice extract. 
$\mathrm{nM}$ ICZ $(\mathrm{P}<0.01)$, and the increase of adduct formation by $0.15 \mu \mathrm{M} \mathrm{GJE}(\mathrm{P}<0.05)$ and $2.3 \mu \mathrm{M} \mathrm{GJE}$ $(\mathrm{P}<0.01)$ were found significant (results not shown).

\section{Gene expression modulation}

To examine whether the effects of (N)AhRAs on BaP-DNA adduct formation could be related to modulation of the expression of biotransformation- or DNA-repair genes, the mRNA levels of several genes involved in these cellular processes have been measured by Q-RT-PCR (Fig. 3). Of the biotransformation enzymes, it is known that they are effected by AhR-activation (Hankinson, 1995; Denison and Nagy, 2003), for the DNA repair enzymes it is not and therefore adding new information.

CYP1A1. BaP increased the mRNA levels of the phase I biotransformation enzyme CYP1A1 by 12 $(0.1 \mu \mathrm{M} \mathrm{BaP})$ to $84(1 \mu \mathrm{M} \mathrm{BaP})$ times (Fig. 3A). Addition of the relatively high (in terms of AhR activation) concentrations of TCDD, ICZ and GJE significantly increased the amount of CYP1A1 mRNA at all BaP concentrations, except for TCDD at $1 \mu \mathrm{M}$ BaP.

CYP1B1. BaP increased the mRNA levels of the phase I biotransformation enzyme CYP1B1 by 2 $(0.1 \mu \mathrm{M} \mathrm{BaP})$ to $7(1 \mu \mathrm{M} \mathrm{BaP})$ times (Fig. 3B). Addition of TCDD and GJE significantly increased the amount of CYP1B1 mRNA caused by BaP (Fig. 3B). ICZ showed only a minor increase at $0.1 \mu \mathrm{M}$ $\mathrm{BaP}$. The induction by ICZ at $1 \mu \mathrm{M} \mathrm{BaP}$ was not determined.

NQO1. No up or down regulation of the phase II biotransformation enzyme NQO1 was observed after exposure to BaP, TCDD and NAhRAs (Results not shown).

GSTP1. BaP caused a 2.5-3 fold increase of the phase II biotransformation enzyme GSTP1 but the response was not dose-related. Although TCDD, ICZ and GJE alone showed significantly a 1.6-2.5 fold increase, they inhibited the GSTP1 induction by BaP at 0.1 and $0.3 \mu \mathrm{M} \mathrm{BaP}$ (except for GJE at $0.1 \mu \mathrm{M} \mathrm{BaP}$ ), whereas they had no effect at $1 \mu \mathrm{M} \mathrm{BaP}$ (Fig. 3C).

UGT1A6. BaP induced this phase II biotransformation enzyme mRNA significantly about twofold. TCDD and the NAhRAs showed a similar induction, and did not have a significant effect in the mixture with $0.1 \mu \mathrm{M}$ BaP (Fig. 3D). The UGT1A6 mRNA induction at higher levels of BaP has not been determined.

ERCC1. BaP had no significant effect on the gene expression of ERCC1 (Fig. 3E). ICZ downregulated the ERCC1-mRNA expression 1.7 times. Co-exposure to TCDD, ICZ and GJE significantly decreased the ERCC1 expression levels found at $0.3 \mu \mathrm{M} \mathrm{BaP}$ nearly two-fold but had no or minimal effects at 0.1 and $1 \mu \mathrm{M} \mathrm{BaP}$.

XPF (ERCC4). The NER enzyme XPF tended to be up-regulated 1.4-2.6 times by TCDD and the NAhRAs and $0.1 \mu \mathrm{M} \mathrm{BaP}$, however not significantly (Fig. 3F). Simultaneous exposure to TCDD had no effect at $0.1 \mu \mathrm{M}$ BaP, but ICZ and GJE decreased the induction at $0.1 \mu \mathrm{M}$ BaP two-fold, but again not significantly. No influence was observed at $0.3 \mu \mathrm{M}$ BaP. No determinations were carried out at 1 $\mu \mathrm{M} \mathrm{BaP}$, and for ICZ at $0.3 \mu \mathrm{M}$ BaP.

$X P G$ (ERCC5). TCDD and the NAhRAs had no significant influence on the induction of the NER enzyme XPG mRNA. BaP showed a 1.6 fold increase at $0.1 \mu \mathrm{M}$ BaP, which was diminished by 


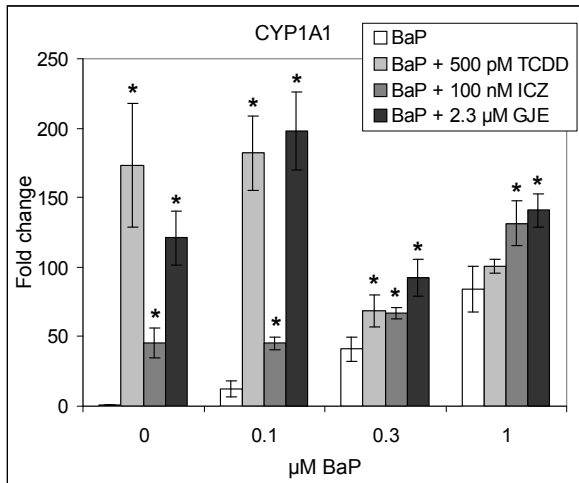

Fig. 3 A

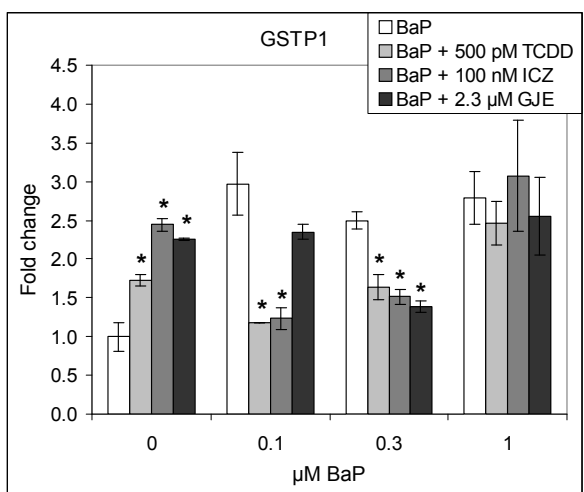

Fig. 3 C

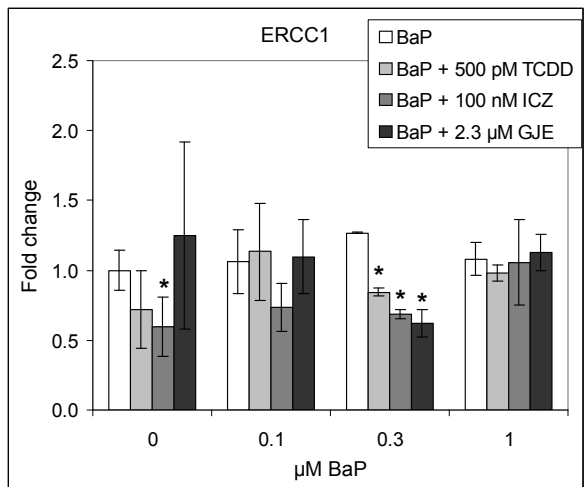

Fig. 3 E

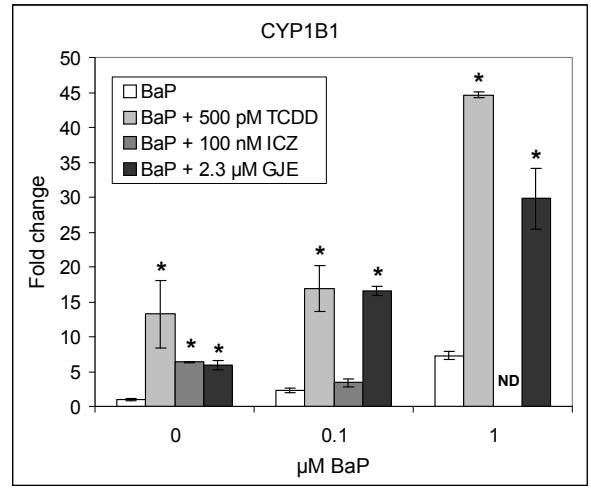

Fig. 3 B

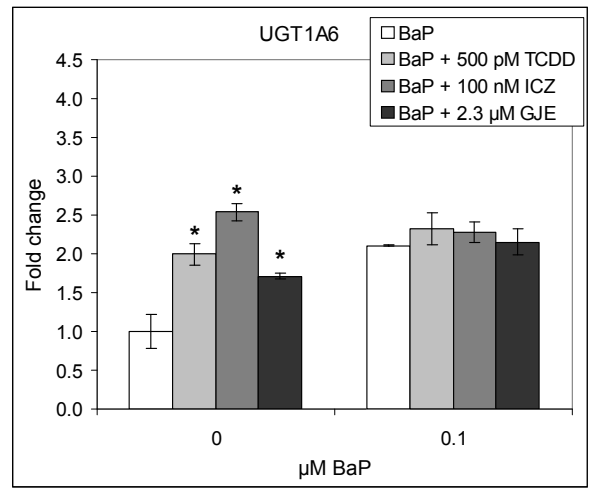

Fig. 3 D

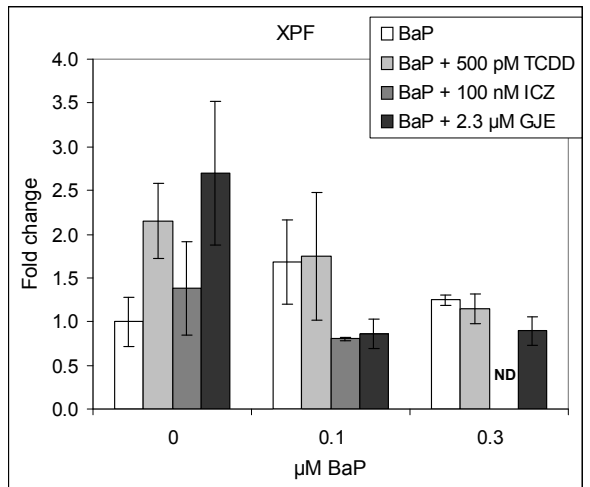

Fig. 3 F

Fig. 3. Induction of mRNA from phase I ( $\mathrm{A}$ and $\mathrm{B})$ and phase II (C and D) biotransformation enzyme genes and nucleotide excision repair (NER) enzyme genes (E-H) in Caco-2 cells after $24 \mathrm{~h}$ of exposure to 0, 0.1, 0.3 and $1 \mu \mathrm{M} \mathrm{BaP}$ alone (white), or these concentrations of $\mathrm{BaP}$ in combination with $500 \mathrm{pM}$ TCDD (light grey), $100 \mathrm{nM}$ ICZ (grey), or $2.3 \mu \mathrm{M}$ GJE (dark grey). At least duplicate exposures $\pm \mathrm{SD},{ }^{\star} \mathrm{P}<0.05$ for the difference between combined exposure and $\mathrm{BaP}$ alone. ICZ, indolo[3,2-b]carbazole; GJE, grapefruit juice extract. ND, not determined. 
addition of TCDD significantly $(\mathrm{P}<0.05)$. GJE decreased the XPG mRNA found at $0.3 \mu \mathrm{M} \mathrm{BaP}$ (results not shown). No analyses were performed at $1 \mu \mathrm{M} \mathrm{BaP}$, and for ICZ at $0.3 \mu \mathrm{M} \mathrm{BaP}$.

$X P A$ and XPC. No significant effects of $\mathrm{BaP}$ alone and in combinations with TCDD or GJE on the NER enzymes XPA and XPC mRNA were observed at $0.3 \mu \mathrm{M} \mathrm{BaP}$ (results not shown). Therefore, no other concentrations of $\mathrm{BaP}$ were tested any more.

\section{Discussion}

In this study we investigated the influence of Natural AhR-activating compounds in fruits and vegetables on BaP-DNA adduct formation in relation to the effect of the prototypical AhR agonist TCDD. Possible differences observed might be explained by differences between TCDD and NAhRAs with respect to the induction of biotransformation or DNA repair activity. As a first step in this complicated process, we evaluated the differences between the effects of TCDD and NAhRAs on BaP-DNA adduct formation in relation to the modulation of expression of genes for several biotransformation and DNA-repair enzymes.

The influence of TCDD and NAhRAs on adduct formation appeared highly dependent on the concentration of BaP. Both TCDD and ICZ appear to reduce the amount of adducts considerable at $0.1 \mu \mathrm{M} \mathrm{BaP}$, while they showed no clear effect at higher concentrations of $\mathrm{BaP}$. This suggests that at low concentrations of $\mathrm{BaP}$, which has a relatively low effect on e.g. CYP 1A1 and 1B1 mRNA levels by itself, the extra induction of CYP1A1 and CYP1B1 by the added AhR agonists can accelerate the elimination of the electrophilic BaP-metabolites out of the cells; at higher concentrations of $\mathrm{BaP}$ this effect already seems to be saturated by BaP itself. This detoxification process by TCDD was not hypothesized, but for ICZ it is in agreement with the findings of Ebert et al, who found that the NAhRAs indole-3-carbinol (I3C, a precursor of ICZ) and flavone induced CYP1A1 in Caco-2 cells, and that pre-treatment with these compounds accelerated metabolism and clearance of BaP (Ebert $e t$ al., 2005b). They also found that I3C, ICZ and also TCDD AhR-dependently induced breast cancer resistance protein (BCRP), which is involved in the transport of phase II metabolites of BaP (Ebert et al., 2005a). Arif et al showed that gavage treatment of I3C to rats exposed to cigarette smoke, inhibited the DNA adduct formation in lung, trachea, bladder and heart, which is also indicative for I3C stimulated BaP removal (Arif et al., 2000). Furthermore, the apparent absence of BaPmetabolization by CYP1A1 and/or CYP1B1 and the subsequent lack of BaP clearance apparently resulting from it, could explain the increase in BaP-DNA adducts in BaP-exposed CYP1A1/1B1 deficient mice (Uno et al., 2004; Uno et al., 2006). In contrast to these findings, the results from some other studies do not support the hypothesis that induction of CYP1A1 and 1B1 decreases the formation of reactive $\mathrm{BaP}$ metabolites. For instance, liver and lung tissues of rats, pretreated with TCDD $48 \mathrm{~h}$ before sacrifice, showed a significant increase in BaP-DNA adducts after in vitro incubation with $10 \mu \mathrm{M} \mathrm{BaP}$, which was related to a higher induction of CYP1A1 and CYP1B1 (Harrigan et al., 2004). Also Shimizu et al reported that BaP-exposed AhR-/- mice, which lacked the CYP1A1 induction, showed no BaP-related tumour formation (Shimizu et al., 2000). A potential other explanation may be that the induction of CYP1A1 and 1B1 results in the accelerated activation 
of $\mathrm{BaP}$, initially resulting in higher DNA-adduct levels, which are subsequently removed by DNArepair. As a result the levels are lower due to the longer time available for the repair enzymes.

The grapefruit juice extract (GJE) showed a completely different effect on BaP-DNA formation than TCDD and ICZ (an increase at $0.1 \mu \mathrm{M} \mathrm{BaP}$ instead of a decrease; and a decrease at 0.3 and $1 \mu \mathrm{M}$ $\mathrm{BaP}$ instead of no effect or a slight increase), although it also strongly induced CYP1A1 and CYP1B1 mRNA. GJE can inhibit the CYP1A1-related 7-ethoxyresorufin-O-deethylase-activity (EROD, (De Waard et al., 2007)) and it has been reported that constituents in grapefruit, e.g. bergamottin, inhibit the enzyme activity of CYP1A1 and CYP1B1 (Baumgart et al., 2005). Inhibition of these enzymes could hamper the rapid clearance of $\mathrm{BaP}$, and thereby cause an increase in DNA-adducts. This would be in agreement with the adduct reducing effects at $0.1 \mu \mathrm{M}$ BaP of TCDD and ICZ, which do not inhibit the CYP enzymes. Additionally, the formation of reactive BaP-metabolites could be reduced by GJE-mediated inhibition of enzyme activity. This might explain why at higher levels of $\mathrm{BaP}$, where the detoxification process seems also saturated according to our TCDD and ICZ results, GJE has a strong reducing effect on the BaP-DNA adduct formation.

Modulating effects on the transcription of the phase II enzymes NQO1, GSTP1 and UGT1A6 and the nucleotide excision repair (NER) enzymes were moderate and could not be related to the different effects on adduct formation by the AhR agonists. Both the expression of GSTP1 and UGT1A6 was slightly induced by TCDD and NAhRAs, but the mixtures with BaP did not show an additive effect, as was seen for the induction of CYP1A1 and CYP1B1, but at 0.1 and $0.3 \mu \mathrm{M}$ $\mathrm{BaP}$ even an inhibition of GSTP1 gene expression. Although the influence on gene expression of the NER enzymes fluctuated considerably between the several BaP, TCDD and NAhRA exposures, presumably the opposite effects on adduct formation by GJE and the other compounds tested are not related to NER enzyme transcription.

We conclude that the influence of TCDD and NAhRAs on BaP-DNA adduct formation is not linearly related to AhR activation, and that ICZ as a single NAhRA-compound shows considerably more resemblance to TCDD, than GJE as a complex mixture containing NAhRAs, at high AhR-activating concentrations. In the lower, and therefore more physiological BaP-concentration range, TCDD and ICZ showed an apparent inhibiting effect on BaP-DNA adduct formation, while the grapefruit juice extract showed a stimulating effect. This seems to contradict our hypothesis based on the presumed toxic properties of TCDD and the healthy properties of citrus fruits. Differences between the effects of TCDD/ICZ and GJE on BaP genotoxicity could not be attributed to phase I and II enzymes and NER enzymes at the transcription level. Therefore, the influences on the dynamic balance between $\mathrm{BaP}$ elimination, bioactivation/DNA-adduct formation and DNA-repair should further also be examined at the level of enzyme activity. Our results emphasize the importance of testing mixtures at realistic concentrations for risk-benefit evaluations. In view of the complex mechanisms our in vitro findings should be confirmed with in vivo studies. 
Chapter 6

\section{ACKNOWLEDgements}

The authors thank Jennifer Collins and Stefan Camps kindly for their contribution to the cell culture, sample treatment and cytotoxicity test. The Dutch Centre of Human Nutrigenomics (CHN) supported this study financially. 


\section{REFERENCES}

Arif, J. M., Gairola, C. G., Kelloff, G. J., Lubet, R. A., and Gupta, R. C. (2000). Inhibition of cigarette smokerelated DNA adducts in rat tissues by indole-3-carbinol. Mutat Res 452, 11-18.

Baird, W. M., Hooven, L. A., and Mahadevan, B. (2005). Carcinogenic polycyclic aromatic hydrocarbon-DNA adducts and mechanism of action. Environ Mol Mutagen 45, 106-114.

Baumgart, A., Schmidt, M., Schmitz, H. J., and Schrenk, D. (2005). Natural furocoumarins as inducers and inhibitors of cytochrome P450 1A1 in rat hepatocytes. Biochem Pharmacol 69, 657-667.

Bergman, J. (1970). Condensation of indole and formaldehyde in the presence of air and sensitizers. Tetrahedron 26, 3353-3355.

Borm, P. J., Knaapen, A. M., Schins, R. P., Godschalk, R. W., and Schooten, F. J. (1997). Neutrophils amplify the formation of DNA adducts by benzo[a]pyrene in lung target cells. Environ Health Perspect 105 Suppl 5, 1089-1093.

Canivenc-Lavier, M. C., Bentejac, M., Miller, M. L., Leclerc, J., Siess, M. H., Latruffe, N., and Suschetet, M. (1996). Differential effects of nonhydroxylated flavonoids as inducers of cytochrome P450 1A and 2B isozymes in rat liver. Toxicol Appl Pharmacol 136, 348-353.

De Waard, W. J., Aarts, J. M. M. J. G., Peijnenburg, A. A. C. M., Baykus, H., Talsma, E., Punt, A., De Kok, T. M. C. M., Van Schooten, F. J., and Hoogenboom, L. A. P. (2007). Gene expression profiling in Caco-2 human colon cells exposed to TCDD, benzo[a]pyrene, and natural Ah receptor agonists from cruciferous vegetables and citrus fruits. Toxicology in Vitro In press.

Denison, M. S., and Nagy, S. R. (2003). Activation of the aryl hydrocarbon receptor by structurally diverse exogenous and endogenous chemicals. Annu Rev Pharmacol Toxicol 43, 309-334.

Ebert, B., Seidel, A., and Lampen, A. (2005a). Identification of BCRP as transporter of benzo[a]pyrene conjugates metabolically formed in Caco-2 cells and its induction by Ah-receptor agonists. Carcinogenesis 26, 17541763 .

Ebert, B., Seidel, A., and Lampen, A. (2005b). Induction of phase-1 metabolizing enzymes by oltipraz, flavone and indole-3-carbinol enhance the formation and transport of benzo[a]pyrene sulfate conjugates in intestinal Caco-2 cells. Toxicol Lett 158, 140-151.

Hanawalt, P. C., Ford, J. M., and Lloyd, D. R. (2003). Functional characterization of global genomic DNA repair and its implications for cancer. Mutat Res 544, 107-114.

Hankinson, O. (1995). The aryl hydrocarbon receptor complex. Annu Rev Pharmacol Toxicol 35, 307-340.

Harrigan, J. A., Vezina, C. M., McGarrigle, B. P., Ersing, N., Box, H. C., Maccubbin, A. E., and Olson, J. R. (2004). DNA adduct formation in precision-cut rat liver and lung slices exposed to benzo[a]pyrene. Toxicol Sci 77, 307-314.

Heber, D. (2004). Vegetables, fruits and phytoestrogens in the prevention of diseases. J Postgrad Med 50, 145149.

Hoogenboom, R. (2002). The combined use of the CALUX bioassay and the HRGC/HRMS method for the detection of novel dioxin sources and new dioxin-like compounds. Environ Sci Pollut Res Int 9, 304306.

Jeuken, A., Keser, B. J. G., Khan, E., Brouwer, A., Koeman, J., and Denison, M. S. (2003). Activation of the Ah receptor by extracts of dietary herbal supplements, vegetables, and fruits. Journal of Agricultural and Food Chemistry 51, 5478-5487.

Lynn, A., Collins, A., Fuller, Z., Hillman, K., and Ratcliffe, B. (2006). Cruciferous vegetables and colo-rectal cancer. Proc Nutr Soc 65, 135-144.

Mimura, J., and Fujii-Kuriyama, Y. (2003). Functional role of AhR in the expression of toxic effects by TCDD. Biochimica Et Biophysica Acta-General Subjects 1619, 263-268.

Mosmann, T. (1983). Rapid colorimetric assay for cellular growth and survival: application to proliferation and cytotoxicity assays. J Immunol Methods 65, 55-63.

Rundle, A. (2006). Carcinogen-DNA adducts as a biomarker for cancer risk. Mutat Res 600, 23-36.

Shah, P., Jogani, V., Bagchi, T., and Misra, A. (2006). Role of Caco-2 cell monolayers in prediction of intestinal drug absorption. Biotechnol Prog. 22, 186-198.

Shimizu, Y., Nakatsuru, Y., Ichinose, M., Takahashi, Y., Kume, H., Mimura, J., Fujii-Kuriyama, Y., and Ishikawa, T. (2000). Benzo[a]pyrene carcinogenicity is lost in mice lacking the aryl hydrocarbon receptor. Proc Natl Acad Sci U S A 97, 779-782. 
Steenland, K., Bertazzi, P., Baccarelli, A., and Kogevinas, M. (2004). Dioxin revisited: developments since the 1997 IARC classification of dioxin as a human carcinogen. Environ Health Perspect 112, 1265-1268.

Steinmetz, K. A., and Potter, J. D. (1996). Vegetables, Fruit, and Cancer Prevention: A Review. Journal of the American Dietetic Association 96, 1027-1039.

Uno, S., Dalton, T. P., Derkenne, S., Curran, C. P., Miller, M. L., Shertzer, H. G., and Nebert, D. W. (2004). Oral exposure to benzo[a]pyrene in the mouse: detoxication by inducible cytochrome P450 is more important than metabolic activation. Mol Pharmacol 65, 1225-1237.

Uno, S., Dalton, T. P., Dragin, N., Curran, C. P., Derkenne, S., Miller, M. L., Shertzer, H. G., Gonzalez, F. J., and Nebert, D. W. (2006). Oral benzo[a]pyrene in Cyp1 knockout mouse lines: CYP1A1 important in detoxication, CYP1B1 metabolism required for immune damage independent of total-body burden and clearance rate. Mol Pharmacol 69, 1103-1114.

van Gils, C. H., Peeters, P. H., Bueno-de-Mesquita, H. B., Boshuizen, H. C., Lahmann, P. H., Clavel-Chapelon, F., Thiebaut, A., Kesse, E., Sieri, S., Palli, D., Tumino, R., Panico, S., Vineis, P., Gonzalez, C. A., Ardanaz, E., Sanchez, M. J., Amiano, P., Navarro, C., Quiros, J. R., Key, T. J., Allen, N., Khaw, K. T., Bingham, S. A., Psaltopoulou, T., Koliva, M., Trichopoulou, A., Nagel, G., Linseisen, J., Boeing, H., Berglund, G., Wirfalt, E., Hallmans, G., Lenner, P., Overvad, K., Tjonneland, A., Olsen, A., Lund, E., Engeset, D., Alsaker, E., Norat, T., Kaaks, R., Slimani, N., and Riboli, E. (2005). Consumption of vegetables and fruits and risk of breast cancer. Jama 293, 183-193.

Van Schooten, F. J., Boots, A. W., Knaapen, A. M., Godschalk, R. W., Maas, L. M., Borm, P. J., Drent, M., and Jacobs, J. A. (2004). Myeloperoxidase (MPO) -463G->A reduces MPO activity and DNA adduct levels in bronchoalveolar lavages of smokers. Cancer Epidemiol Biomarkers Prev 13, 828-833.

Verhoeven, D. T., Goldbohm, R. A., van Poppel, G., Verhagen, H., and van den Brandt, P. A. (1996). Epidemiological studies on brassica vegetables and cancer risk. Cancer Epidemiol Biomarkers Prev 5, 733-748.

Yu, J., Wang, L., Walzem, R. L., Miller, E. G., Pike, L. M., and Patil, B. S. (2005). Antioxidant activity of citrus limonoids, flavonoids, and coumarins. J Agric Food Chem 53, 2009-2014. 


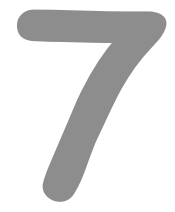

Summary and general discussion 



\section{SUMMARY}

Although contrasting observations have been done during the last decade, there is no doubt that the high consumption of vegetables and fruits can been linked to health effects in humans (Wattenberg, 1971; Steinmetz and Potter, 1996; Verhoeven et al., 1996; Heber, 2004; WCRF/AICR, 2007). Yet, various vegetables and fruits contain natural compounds, or their precursors, which can bind and activate the aryl hydrocarbon receptor (AhR). Because the activation of this receptor is thought to be essential in the toxicity of dioxins, a well-known group of environmental pollutants, it is of great importance to investigate whether these natural AhR-agonists (NAhRAs) may also exert similar toxic effects as dioxins, or dioxin-like compounds (Fernandez-Salguero et al., 1996; Safe, 2001; Mimura and Fujii-Kuriyama, 2003; Steenland et al., 2004). The importance of investigating such a potential health concern is even more evident in view of the fact that the intake of high doses of purified NAhRAs is being promoted as healthy food supplements. The interest in this type of food supplements is based on the observation that some identified NAhRAs from vegetables and fruits, like indole-3-carbinol (I3C) in cruciferous vegetables, furocoumarins in citrus fruits and flavonoids such as chrysin, baicalein and cantharidin in vegetables and herbs, can show health promoting effects, especially as tumor suppressors, and are thought to be an important cause for the observed beneficial effects of vegetable and fruit enriched diets (Zhang et al., 2003; Aggarwal and Ichikawa, 2005; Chlouchi et al., 2007; WCRF/AICR, 2007). It is remarkable that the proposed mechanism of anti-tumor activity is also based on the AhR activation, and the subsequent induction of phase I and II biotransformation enzymes like CYP1A1, CYP1A2 and UDPGT1A6 (Broadbent and Broadbent, 1998a; Broadbent and Broadbent, 1998b). This seemingly contradiction of both toxic and health beneficial effects initiated by the same receptor may be caused by differences down-stream the AhRactivation or alternative mechanisms besides the AhR-activation.

In this thesis we investigated to what extent the effects of NAhRAs are comparable with the effects of the most potent dioxin 2,3,7,8-tetrachlorodibenzo-p-dioxin (TCDD) at the transcriptomic and genotoxic level in human cells. Therefore, we examined the gene expression profiles in human colon cancer cells and lymphocytes after exposure to some specific NAhRAs and the xenobiotic AhR-agonists TCDD and benzo[a]pyrene (BaP). Based on the transcriptome of these compounds or extracts we attempted to determine relevant NAhRA-specific biomarkers in the human body after consumption of foods rich in NAhRAs. As interspecies differences of dioxin toxicity can be huge (Panteleyev and Bickers, 2006), it appears of great importance that human in vitro and in vivo models were used.

In order to identify the major types of NAhRA-containing foods and to estimate the overall dietary intake of NAhRAs, we measured the AhR-activity of extracts of a large number of frequently consumed food items using the DR CALUX' -reporter gene bioassay (chapter 3). The CALUX-induction of the food extracts was compared with the induction by the prototypical dioxin AhR-agonist TCDD. Besides extracts of cruciferous vegetables and citrus products, also extracts of potatoes, bread and hamburgers contained a relatively high AhR-activity. Estimation of TCDD-induction equivalents 
demonstrated that the amount of NAhRAs present in food is significantly higher than the amount of xenobiotic AhR-agonists as dioxins and dioxin-like compounds. Although the calculation of TCDD-induction equivalents strongly depends on the exposure time of the CALUX-cells to the test samples, we conclude that the exposure of humans to NAhRAs in foods is quite substantial (possibly in the order of thousands of pg TCDD-IEQ/day).

In chapter 2, the effect of NAhRAs, TCDD and $\mathrm{BaP}$ on the gene expression is described. These effects have been established in human colon Caco-2 cells exposed to concentrations of near maximum AhR-activation as measured by the DR CALUX assay. Using the microarray technique, the expression of more than 1000 different genes was measured, and more than 20 genes were found to be up- or down-regulated by at least 1.5 times by TCDD. Most of these by TCDD affected genes were in the same way and to about the same extent up- or down-regulated by $\mathrm{BaP}$ and the NAhRA samples. The same phase I and II biotransformation enzymes like CYP1A1, CYP1B1 and UDPGT1A6, and a number of genes involved in cell proliferation were elevated to the same magnitude. Although not extensively investigated, for it was not the scope of this study, no important differences in gene regulation could be detected between NAhRAs and TCDD. The large overlap of gene expression profiles in Caco-2 cells after exposure to NAhRAs and the xenobiotic AhR agonists was not expected. However, although significant differences have been shown in other studies between the effects on gene expression of TCDD, BaP and some NAhRAs such as indirubin and diindolylmethane (DIM) in both several human cell lines, animal models and tissues, all studies show a similar very high induction of CYP1A1 and substantial induction of a number of other genes for xenobiotic metabolism. Sometimes, also comparable effects are shown for cell proliferation, cell cycle regulation and estrogen metabolism in these studies (Puga et al., 2000; Frueh et al., 2001; Sanderson et al., 2001; Martinez et al., 2002; Adachi et al., 2004; Hanlon et al., 2005; Boverhof et al., 2006; Frericks et al., 2007; Hockley et al., 2007). Possibly, for some NAhRAs the presumed beneficial effects may be caused by a difference with TCDD at the protein-activity level. We found that one of the NAhRA samples tested, an extract of grapefruit juice, induced the AhR-related gene expression strongly, but inhibited the enzymatic activity of the gene product CYP1A1 as measured by the EROD-assay, in contrast with TCDD and indolo[3,2-b]carbazol (ICZ, an acid reaction product of I3C and one of the most potent NAhRAs). The TCDD-like gene expression profiles of the NAhRAs suggest that NAhRAs may indeed induce TCDD-like toxicity, and therefore we determined whether the expression of the most important AhR-responsive genes could also be detected in ex vivo exposed human lymphocytes. Blood is a relatively easy obtainable human tissue, and finding genomics biomarkers for exposure or effects in human blood cells would enable toxicological evaluation of NAhRA exposure in human populations. For that purpose, in chapter 4 we tested if a same kind of gene expression profile as in Caco-2 cells could be shown in freshly isolated human lymphocytes after in vitro exposure to NAhRAs and TCDD. Although the lymphocytes appeared to be less sensitive than the Caco-2 cells, a small number of AhR-specific genes were significantly upregulated, including CYP1A1, CYP1B1 and NQO1 $(\mathrm{NAD}(\mathrm{P}) \mathrm{H}$ quinone oxidoreductase 1, a phase II biotransformation enzyme). As the elevated expression of these three genes was considered to be 
a promising biomarker for human exposure to AhR-agonists, a pilot study was initiated to verify the up-regulation of these three genes in human blood cells after consumption of NAhRA-rich food items. The screening of foods using the DR CALUX' assay had shown that most NAhRA-activity was found in grapefruit juice and cruciferous vegetables (chapter 3), so these were used for a three-day intervention study. Although the level of NAhRA intake was considerable, no up-regulation of gene expression of CYP1A1, CYP1B1 or NQO1 could be detected both 3 and 24 hours after the dietary intervention. Two alternative measurements were performed to establish AhR-related activity after the dietary intervention. Firstly, the effect of the intervention on CYP1A2 induction was determined by measuring caffeine-metabolite ratios in urine samples, and secondly, the DR CALUX'-activity was measured in plasma samples. No effect on CYP1A2 induction could be detected, although studies with comparable amounts of cruciferous vegetables showed CYP1A2 induction by way of altered caffeine metabolism (Kall et al., 1996; Lampe et al., 2000), but the DR CALUX'-assay showed a slight increase in activity after consumption of cruciferous vegetables. A very sensitive, newly developed gene reporter assay, the Dioxin Responsive Element-driven Chemical Activated FLUorescent protein eXpression (DRE-CAFLUX) assay confirmed the slight elevation in AhR-activity found in the human plasma samples from the intervention with cruciferous vegetables (chapter 5). Although the AhR-activity in grapefruit juice extract (GJE) was much higher than in the cruciferous vegetables, the NAhRAs in GJE do not appear to reach the bloodstream in high amounts. Therefore it can be concluded that gene expression profiling in human lymphocytes is not a very sensitive method for the detection for NAhRA-exposure or AhR-related effects in humans, and does not seem suitable for the screening of human populations.

To investigate the effects of the presumed tumor promoter TCDD and the presumed tumor suppressing NAhRAs on the genotoxicity of $\mathrm{BaP}$ in vitro, we exposed human Caco-2 colon cancer cells to mixtures of $\mathrm{BaP}$ and either TCDD or NAhRAs (chapter 6). We hypothesized that the induction of CYP1A1 and CYP1B1 phase I biotransformation enzymes by the activation of the AhR would result in a faster metabolic conversion of $\mathrm{BaP}$ into the electrophilic epoxide benzo[a] pyrene-7,8-diol-9,10-epoxide (BPDE) and the increased induction of BaP-DNA adducts. On the contrary, we found that at low BaP concentration both TCDD and ICZ decreased the amount of BaP-DNA adducts in a dose-dependent manner. At this low, and thus physiologically more relevant concentration of BaP, GJE showed the opposite effect, namely a doubling in the formation of BaPDNA adducts. At higher concentrations of BaP, where TCDD and ICZ both did not show an effect, GJE could decrease the amount of BaP-DNA adduct formation significantly. These results could not be related to the gene expression of a number of phase I and II enzymes, and nucleotide excision repair enzymes (NER). This indicates, again, that important health related effects of NAhRAs may be induced at the protein level and not at the transcriptome level. Interestingly, this model suggests that under certain conditions dioxin-like compounds can show a beneficial effect, while some NAhRAs can show a potential toxic effect. 


\section{BENEFICIAL FOOD COMPONENTS...?}

Although certainly not all epidemiological studies show a reduced cancer risk as a result of high intake of vegetables and fruits (van Gils et al., 2005; Lynn et al., 2006), there is ample evidence that a relatively high amount of vegetables and fruits in the human diet has more beneficial than detrimental effects on human health (WCRF/AICR, 2007). However, the beneficial effects ascribed to phytochemicals present in the diet do not necessarily have to be found after intake of such compounds as food supplements. E.g., a recent systematic review and meta-analysis of extensively studied use of antioxidant supplements, does not show a beneficial effect on human cancer and cardiovascular mortality (Bjelakovic et al., 2007). Thus, thinking of chemopreventive or medicinal use of phytochemicals, one should be cautious for high doses of pure compounds, because it may cause adverse side effects (Verschoyle et al., 2007). The NAhRA I3C, also considered to be an antioxidant (Shertzer and Sainsbury, 1991), is now sold on the market as a food supplement to be taken in relatively high doses (Zeligs, 2002). Extensive animal studies showed a significant anticancer property of I3C (Broadbent and Broadbent, 1998b; Aggarwal and Ichikawa, 2005) and clinical trials in women have shown chemopreventive effects against breast and cervical cancer (Aggarwal and Ichikawa, 2005; Reed et al., 2005). However, these chemopreventive effects are related to an increased hormonal 2-hydroxyestrone/16a-hydroxyestrone ratio caused by the induced enzyme activity of CYP1A1/1A2 (Bradlow et al., 1996; Aggarwal and Ichikawa, 2005), which is AhRdependent and also affected in the same way by TCDD (Gierthy et al., 1988; Bertazzi et al., 1993; Greenlee et al., 2001). Besides, an inhibitory AhR-estrogen receptor a cross-talk is considered to be even more important in the anti-estrogenic effects of AhR-agonists like TCDD (Safe and Wormke, 2003; Matthews and Gustafsson, 2006). Because of these chemoprotective effects, selective AhRagonists, like 2,3,7,8-tetrachlorophenothiazine (TCPT) and various substituted diindolylmethanes (DIMs), are under investigation for possible anticancer agents (Safe et al., 1999; Morrow et al., 2004; Fried et al., 2007).

Interestingly, although TCDD can be toxic at relatively low doses for a number of animals, epidemiological studies can not clearly prove this for humans yet (Steenland et al., 2004; Connor and Aylward, 2006; Guzelian et al., 2006). Besides the above mentioned anti-estrogenic effects of TCDD, a case-control study of a normal human population in Finland showed that the risk of soft tissue sarcoma was highest in the lowest dioxin exposed group, whereas similarly as in rat studies the risk was smallest at the high-end range of dioxin concentrations (Tuomisto, 2005), also suggesting some health beneficial effects from low amounts of TCDD.

From this point of view, NAhRAs in a complex food environment can have health beneficial effects, probably by a subtle induction of a number of phase I and phase II enzymes, which may be a mechanism for tumor suppression of certain cancers.

\section{... OR UNPERCEIVED RISK FACTORS?}

On the other hand, many animal experiments showed a high toxicity for TCDD at low levels, which makes it a severe environmental pollutant, and several human epidemiological findings suggest a 
possible increment of certain cancers after exposure to high dioxin concentrations, e.g. at the Seveso accident in Italy in 1976 (Bertazzi et al., 1993; Warner et al., 2005). Also the effect of chloracne is well-known for industrial workers employed in the production of various chlorinated chemicals, industrial accidents, American veterans from the Vietnam war, exposed to TCDD-containing defoliants (like Agent Orange) and recently, the TCDD-poisoning of the Ukrainian president Yushchenko in 2004 (Sterling and Hanke, 2005; Panteleyev and Bickers, 2006). Because these toxic effects are thought to be mediated by the AhR (Fernandez-Salguero et al., 1996; Mimura and FujiiKuriyama, 2003; Steenland et al., 2004), it is important to evaluate whether this toxicity can also be induced by high doses of NAhRAs, for instance as a result of dietary intake or prolonged use of supplements.

In Chapter 2 it is demonstrated that the global gene expression in a human colon cell line after exposure to NAhRAs shows a quite similar profile as after exposure to TCDD, and most of the affected genes are theoretically involved in dioxin toxicity. Other similarities in expression of genes related to NAhRAs and TCDD were determined in a number of in vitro and in vivo models. Besides the induction of the prototypical AhR responsive genes for CYP1A1, CYP1A2, CYP1B1, GST, UDPGT and NQO (Broadbent and Broadbent, 1998a; Broadbent and Broadbent, 1998b), I3C or ICZ can cause, like TCDD, weak estrogenic effects like binding to an estrogen responsive element (Liu et al., 1994; Ohtake et al., 2003), and reproductive abnormalities in male rat offspring (Wilker et al., 1996). ICZ caused TCDD-like gap-junction intercellular communication inhibition, which is considered to play a role in tumor promotion (Herrmann et al., 2002) and increased COX-2 expression leading to enhanced prostaglandin E2 production and colon cancer progression (Sherratt et al., 2003). Also, I3C can cause tumor promotion in several animal models (Dashwood, 1998). However, unlike TCDD, the strong NAhRA 2-(1'H-indole-3'-carbonyl)-thiazole-4-carboxylic acid methyl ester (ITE, a hypothetical endogenous AhR ligand) did not induce cleft palate or hydronephrosis in the mouse, a typical teratogenic effect of TCDD (Henry et al., 2006).

Overall, these similarities and differences in effects of NAhRAs and TCDD suggest a delicate balance in mechanistic effects. Besides, some toxic effects of TCDD can not be clearly related to the AhR-activation, like the ARNT-independent activation of the epidermal growth factor receptor (EGFR) and activation of c-Src kinase which are probably involved in loss of body weight ("wasting syndrome") and epithelial hyperplasia (Panteleyev and Bickers, 2006), an alternative way to explain differences in effects between dioxins and NAhRAs.

Some important problems concerning the risk assessment of AhR agonists are the still unrevealed mechanisms of dioxin toxicity (Steenland et al., 2004; Connor and Aylward, 2006), the animal species specificity, and the difficulties in using the TEQ-concept in a proper way for non-dioxin-like agonists (Safe, 1998; Windal et al., 2005). The latter is discussed in chapter 3. It is suggested that the difference between the AhR-related potential toxic effects of dioxins and NAhRAs probably depends highly on the persistent properties of the dioxins in the body (Bock and Kohle, 2006). The half-life of TCDD is much longer than that of the known NAhRAs (Pohjanvirta et al., 2002), which implies that the dioxins can accumulate in tissue and cause a continuous over-activation of the AhR. This may 
eventually result in increased toxicological risk. On the other hand, one could argue that, because of the continuous exposure to dietary NAhRAs (Chapter 3), the AhR may also be continuously activated, comparable with dioxin exposure.

Different approaches have been used to estimate the possible toxic dose of dioxin-like compounds. Both the EC Scientific Committee for Food (SCF) and the FAO/WHO Joint Expert Committee on Food Additives (JECFA) derived a tolerable weekly intake (TWI) of $14 \mathrm{pg}$ WHO-TEQ/kg bw (Larsen, 2006). This level is based on the most sensitive adverse effects reported for TCDD, namely developmental and reproductive effects in rats. The US Environmental Protection Agency (US EPA) calculated the human body burdens of dioxin and dioxin-like substances leading to an estimated $1 \%$ increase $\left(\mathrm{ED}_{01}\right)$ in the lifetime risk of cancer in three occupational studies with the best exposure information, and the $\mathrm{ED}_{01}$ ranged from 6 to $62 \mathrm{ng} \mathrm{TCDD} / \mathrm{kg}$ bw (Larsen, 2006). Animal data fell in the middle of this range. For the pivotal noncancer hazards, the EPA used the margin of exposure (MOE), which is the ratio of effect level in the comparison species $\left(\mathrm{ED}_{01}\right.$ or LOEL, i.e. lowest observed effect level) to the human body burden. For the most sensitive endpoints, the MOE ranged from less than 1 for enzyme induction in mice and rats, 4 for developmental neurotoxicity and endometriosis in non-human primates, 5-8 for developmental/reproductive toxicity in rats, and 12 for developmental immunotoxicity in rats (Larsen, 2006). Connor and Aylward reviewed a number of human and animal studies on TCDD exposures which showed that significant CYP1A enzyme activity or CYP1A gene expression in humans occurred at the level above $750 \mathrm{ng}$ WHO-TEQ/kg/ day (no such effect below $250 \mathrm{ng} / \mathrm{kg} /$ day, lacking data in between) and in marmoset monkey, mouse and rat above ca. $50 \mathrm{ng} / \mathrm{kg} /$ day (Connor and Aylward, 2006). This was correlated with a suggested "impaired" human AhR with a receptor binding affinity of TCDD about 10 times less than in the concerned animal models, which may imply that humans are possibly less vulnerable than these animals used for the risk assessment of dioxins and dioxin-like compounds (Connor and Aylward, 2006; Larsen, 2006). In chapter 3 we estimated the total intake of NAhRA-containing foods at 1545$6235 \mathrm{pg}$ TCDD-IEQ/day, which corresponds with a daily body burden, based on a person of $70 \mathrm{~kg}$, of 22-89 pg TCDD-IEQ/kg bw. Taken into account that NAhRAs have, in contrast with dioxins, probably a short half-life, it could be concluded that the exposure to NAhRAs is too low to be able to induce CYP1A activity and so exhibiting the dioxin-like toxicity related to this enzyme induction. However, according to the WHO-TWI and the EPA-MOE, the NAhRA-intake is far above the safety margins. But using the dioxin TEQ-concept for non-dioxin-like compounds or mixtures is highly controversial, and probably unrealistic. In chapter 3 we discussed that the calculations of TCDDIEQs made by Jeuken et al (Jeuken et al., 2003) were three orders of magnitude higher than ours, because of a shorter exposure time in the DR CALUX bioassay. This makes it very complicated to accurately estimate the dose of AhR-activating compounds. Furthermore, total body burden may not be a very useful parameter, because NAhRAs probably concentrate in relatively high amounts in certain target tissues like the liver (Stresser et al., 1995; Anderton et al., 2004). 


\section{Conclusion}

In chapter 4 it is seen that a relatively high intake of NAhRA-containing foods $(900-20000 \mathrm{pg}$ TCDD-IEQ/day) could not be clearly related to AhR effects in human lymphocytes. Either this effect is absent, or alternatively the used biomarkers in lymphocytes are not sufficiently sensitive for detection of the aimed AhR-related effects and are also probably not related to the most sensitive adverse effects of TCDD, such as endocrine disruption and developmental and reproductive toxicity. Together with the relatively high amounts of NAhRAs given to laboratory animals to cause AhRrelated effects, it can be argued that AhR activation by consumption of NAhRA-containing foods will probably not reach the toxic level as induced by a high dose of TCDD. Also the CYP-enzyme inhibiting properties of some NAhRAs, like bergamottin in grapefruit juice as seen in chapter 2 and demonstrated by Baumgart et al (Baumgart et al., 2005), and the complex composition of foods with many possible inhibitors of AhR-activity (Amakura et al., 2003; Zhang et al., 2003), support this conclusion. Also other compounds in foods, like the isothiocyanates in cruciferous vegetables (Higdon et al., 2007), can compensate the hypothetical adverse effects of NAhRAs by selectively inducing phase II enzymes, which may efficiently eliminate electrophylic metabolites generated by upregulated phase I enzymes. More caution may be necessary for the intake of NAhRAs as food supplements. It is often recommended to take such supplements in a pure form on a daily basis and in doses which are often hundreds of times higher as compared to normal dietary intake (Zeligs, 2002; Bagchi, 2006; Verschoyle et al., 2007; WCRF/AICR, 2007). In view of the unpredictable influence on DNA-adduct formation by environmental carcinogens such as PAHs, as seen in chapter $\mathbf{6}$, these supplements may result e.g. in an increased genotoxic risk under certain conditions and eventually promote tumor formation in the longer run.

\section{FUTURE RESEARCH}

The use of genomics in food and toxicology research appears to be a promising approach to establish mechanistic pathways involved in both chemopreventive and toxic effects of dietary compounds. At this moment, transcriptomics has shown to be a powerful technique for screening genome-wide gene expression. However, as seen in this thesis, the sensitivity of this technique may sometimes be too low to establish gene expression changes in certain cell types. More importantly, not all the essential steps in the mechanistic pathways are represented at the transcriptomic level. Therefore, an integrated systems biology approach for risk/benefit analysis of specific foods, by using the combination of transcriptomics with proteomics and metabolomics, may be necessary to find useful biomarkers. (Gatzidou et al., 2007; Collings and Vaidya, 2008; Decristofaro and Daniels, 2008). Much attention should be paid on tissue specificity and time of sampling, and probably pathway analysis will be a promising tool for obtaining biomarkers, instead of the determination of a number of affected genes or proteins. With regard to the research on the effects of AhR-activation, we recommend to use both the persistent xenobiotics like TCDD and some of the more rapidly metabolized NAhRAs in the same test models, to observe where these types of AhR-agonists show their different effects. Also attention should be paid to antagonistic effects of compounds e.g. in food. Preferably human in vitro 
and in vivo (for NAhRAs) models should be used, because of the large interspecies differences in AhR-related effects. Because the necessary amount of sample for -omics studies is still decreasing, very small biopts of more relevant human tissues, such as epithelial cells or colon cells, may replace the relatively non-invasive blood sampling. However, to obtain insight in the mechanisms of the most sensitive toxic effects such as reproductive and developmental toxicity, the systems biology approach should probably first be applied to the most suitable animal models. All this implicates a complex and costly, but very promising, research, which may be more appropriate for environmental risk assessment, and also potential pharmaceutical purposes, than for developing food supplements intended for healthy humans (for: "An apple a day keeps cancer away"). 


\section{REFERENCES}

Adachi, J., Mori, Y., Matsui, S., and Matsuda, T. (2004). Comparison of gene expression patterns between 2,3,7,8-tetrachlorodibenzo-p-dioxin and a natural arylhydrocarbon receptor ligand, indirubin. Toxicol Sci 80, 161-169.

Aggarwal, B. B., and Ichikawa, H. (2005). Molecular targets and anticancer potential of indole-3-carbinol and its derivatives. Cell Cycle 4, 1201-1215.

Amakura, Y., Tsutsumi, T., Sasaki, K., Yoshida, T., and Maitani, T. (2003). Screening of the inhibitory effect of vegetable constituents on the aryl hydrocarbon receptor-mediated activity induced by 2,3,7,8-tetrachlorodibenzo-p-dioxin. Biol Pharm Bull 26, 1754-1760.

Anderton, M. J., Manson, M. M., Verschoyle, R. D., Gescher, A., Lamb, J. H., Farmer, P. B., Steward, W. P., and Williams, M. L. (2004). Pharmacokinetics and tissue disposition of indole-3-carbinol and its acid condensation products after oral administration to mice. Clin Cancer Res 10, 5233-5241.

Bagchi, D. (2006). Nutraceuticals and functional foods regulations in the United States and around the world. Toxicology 221, 1-3.

Baumgart, A., Schmidt, M., Schmitz, H. J., and Schrenk, D. (2005). Natural furocoumarins as inducers and inhibitors of cytochrome P450 1A1 in rat hepatocytes. Biochem Pharmacol 69, 657-667.

Bertazzi, P. A., Pesatori, A. C., Consonni, D., Tironi, A., Landi, M. T., and Zocchetti, C. (1993). Cancer incidence in a population accidentally exposed to 2,3,7,8-tetrachlorodibenzo-p-dioxin. Epidemiology 4, 398-406.

Bjelakovic, G., Nikolova, D., Gluud, L. L., Simonetti, R. G., and Gluud, C. (2007). Mortality in randomized trials of antioxidant supplements for primary and secondary prevention: systematic review and meta-analysis. Jama 297, 842-857.

Bock, K. W., and Kohle, C. (2006). Ah receptor: dioxin-mediated toxic responses as hints to deregulated physiologic functions. Biochem Pharmacol 72, 393-404.

Boverhof, D. R., Burgoon, L. D., Tashiro, C., Sharratt, B., Chittim, B., Harkema, J. R., Mendrick, D. L., and Zacharewski, T. R. (2006). Comparative toxicogenomics analysis of the hepatotoxic effects of TCDD in Sprague Dawley rats and C57BL/6 mice. Toxicol Sci 94, 398-416.

Bradlow, H. L., Telang, N. T., Sepkovic, D. W., and Osborne, M. P. (1996). 2-hydroxyestrone: the 'good' estrogen. J Endocrinol 150 Suppl, S259-265.

Broadbent, T. A., and Broadbent, H. S. (1998a). 1 - 1. The chemistry and pharmacology of indole-3-carbinol (indole-3-methanol) and 3-(methoxymethyl)indole. [Part I]. Curr Med Chem 5, 337-352.

Broadbent, T. A., and Broadbent, H. S. (1998b). 1. The chemistry and pharmacology of indole-3-carbinol (indole3-methanol) and 3-(methoxymethyl)indole. [Part II]. Curr Med Chem 5, 469-491.

Chlouchi, A., Girard, C., Bonet, A., Viollon-Abadie, C., Heyd, B., Mantion, G., Martin, H., and Richert, L. (2007). Effect of chrysin and natural coumarins on UGT1A1 and 1A6 activities in rat and human hepatocytes in primary culture. Planta Med. 73, 742-747.

Collings, F. B., and Vaidya, V. (2008). Novel technologies for the discovery and quantitation of biomarkers of toxicity. Toxicology 245, 167-174.

Connor, K. T., and Aylward, L. L. (2006). Human response to dioxin: aryl hydrocarbon receptor (AhR) molecular structure, function, and dose-response data for enzyme induction indicate an impaired human AhR. $J$ Toxicol Environ Health B Crit Rev 9, 147-171.

Dashwood, R. H. (1998). Indole-3-carbinol: anticarcinogen or tumor promoter in brassica vegetables? Chem Biol Interact 110, 1-5.

Decristofaro, M. F., and Daniels, K. K. (2008). Toxicogenomics in biomarker discovery. Methods Mol Biol 460, 185-194.

Fernandez-Salguero, P. M., Hilbert, D. M., Rudikoff, S., Ward, J. M., and Gonzalez, F. J. (1996). Aryl-hydrocarbon receptor-deficient mice are resistant to 2,3,7,8-tetrachlorodibenzo-p-dioxin-induced toxicity. Toxicol Appl Pharmacol 140, 173-179.

Frericks, M., Meissner, M., and Esser, C. (2007). Microarray analysis of the AHR system: tissue-specific flexibility in signal and target genes. Toxicol Appl Pharmacol 220, 320-332.

Fried, K. W., Schneider, C. M., Schramm, K. W., Datta, A., Chahbane, N., Corsten, C., Powell, D. R., Lenoir, D., Kettrup, A., Terranova, P., Georg, G. I., and Rozman, K. K. (2007). From Dioxin to Drug Lead-The Development of 2,3,7,8-Tetrachlorophenothiazine. ChemMedChem 2, 890-897.

Frueh, F. W., Hayashibara, K. C., Brown, P. O., and Whitlock, J. P., Jr. (2001). Use of cDNA microarrays to analyze dioxin-induced changes in human liver gene expression. Toxicol Lett 122, 189-203. 
Gatzidou, E. T., Zira, A. N., and Theocharis, S. E. (2007). Toxicogenomics: a pivotal piece in the puzzle of toxicological research. J Appl Toxicol 27, 302-309.

Gierthy, J. F., Lincoln, D. W., 2nd, Kampcik, S. J., Dickerman, H. W., Bradlow, H. L., Niwa, T., and Swaneck, G. E. (1988). Enhancement of 2- and 16 alpha-estradiol hydroxylation in MCF-7 human breast cancer cells by 2,3,7,8-tetrachlorodibenzo-P-dioxin. Biochem Biophys Res Commun 157, 515-520.

Greenlee, W. E., Hushka, L. J., and Hushka, D. R. (2001). Molecular basis of dioxin actions: evidence supporting chemoprotection. Toxicol Pathol 29, 6-7.

Guzelian, P., Quattrochi, L., Karch, N., Aylward, L., and Kaley, R. (2006). Does dioxin exert toxic effects in humans at or near current background body levels?: An evidence-based conclusion. Hum Exp Toxicol 25, 99-105.

Hanlon, P. R., Zheng, W., Ko, A. Y., and Jefcoate, C. R. (2005). Identification of novel TCDD-regulated genes by microarray analysis. Toxicol Appl Pharmacol 202, 215-228.

Heber, D. (2004). Vegetables, fruits and phytoestrogens in the prevention of diseases. J Postgrad Med 50, $145-$ 149.

Henry, E. C., Bemis, J. C., Henry, O., Kende, A. S., and Gasiewicz, T. A. (2006). A potential endogenous ligand for the aryl hydrocarbon receptor has potent agonist activity in vitro and in vivo. Arch Biochem Biophys 450, 67-77.

Herrmann, S., Seidelin, M., Bisgaard, H. C., and Vang, O. (2002). Indolo[3,2-b]carbazole inhibits gap junctional intercellular communication in rat primary hepatocytes and acts as a potential tumor promoter. Carcinogenesis 23, 1861-1868.

Higdon, J. V., Delage, B., Williams, D. E., and Dashwood, R. H. (2007). Cruciferous vegetables and human cancer risk: epidemiologic evidence and mechanistic basis. Pharmacol Res 55, 224-236.

Hockley, S. L., Arlt, V. M., Brewer, D., te Poele, R., Workman, P., Giddings, I., and Phillips, D. H. (2007). AHRand DNA-damage-mediated gene expression responses induced by benzo[a]pyrene in human cell lines. Chem Res Toxicol 20, 1797-1810.

Jeuken, A., Keser, B. J. G., Khan, E., Brouwer, A., Koeman, J., and Denison, M. S. (2003). Activation of the Ah receptor by extracts of dietary herbal supplements, vegetables, and fruits. Journal of Agricultural and Food Chemistry 51, 5478-5487.

Kall, M. A., Vang, O., and Clausen, J. (1996). Effects of dietary broccoli on human in vivo drug metabolizing enzymes: evaluation of caffeine, oestrone and chlorzoxazone metabolism. Carcinogenesis 17, 793-799.

Lampe, J. W., King, I. B., Li, S., Grate, M. T., Barale, K. V., Chen, C., Feng, Z., and Potter, J. D. (2000). Brassica vegetables increase and apiaceous vegetables decrease cytochrome P450 1A2 activity in humans: changes in caffeine metabolite ratios in response to controlled vegetable diets. Carcinogenesis 21, 1157-1162.

Larsen, J. C. (2006). Risk assessments of polychlorinated dibenzo-p-dioxins, polychlorinated dibenzofurans, and dioxin-like polychlorinated biphenyls in food. Mol Nutr Food Res 50, 885-896.

Liu, H., Wormke, M., Safe, S. H., and Bjeldanes, L. F. (1994). Indolo[3,2-b]carbazole: a dietary-derived factor that exhibits both antiestrogenic and estrogenic activity. J Natl Cancer Inst 86, 1758-1765.

Lynn, A., Collins, A., Fuller, Z., Hillman, K., and Ratcliffe, B. (2006). Cruciferous vegetables and colo-rectal cancer. Proc Nutr Soc 65, 135-144.

Martinez, J. M., Afshari, C. A., Bushel, P. R., Masuda, A., Takahashi, T., and Walker, N. J. (2002). Differential toxicogenomic responses to 2,3,7,8-tetrachlorodibenzo-p-dioxin in malignant and nonmalignant human airway epithelial cells. Toxicol Sci 69, 409-423.

Matthews, J., and Gustafsson, J. A. (2006). Estrogen receptor and aryl hydrocarbon receptor signaling pathways. Nucl Recept Signal, doi: 10.1621/nrs.04016.

Mimura, J., and Fujii-Kuriyama, Y. (2003). Functional role of AhR in the expression of toxic effects by TCDD. Biochimica Et Biophysica Acta-General Subjects 1619, 263-268.

Morrow, D., Qin, C., Smith, R., 3rd, and Safe, S. (2004). Aryl hydrocarbon receptor-mediated inhibition of LNCaP prostate cancer cell growth and hormone-induced transactivation. J Steroid Biochem Mol Biol 88, 27-36.

Ohtake, F., Takeyama, K., Matsumoto, T., Kitagawa, H., Yamamoto, Y., Nohara, K., Tohyama, C., Krust, A., Mimura, J., Chambon, P., Yanagisawa, J., Fujii-Kuriyama, Y., and Kato, S. (2003). Modulation of oestrogen receptor signalling by association with the activated dioxin receptor. Nature 423, 545-550.

Panteleyev, A. A., and Bickers, D. R. (2006). Dioxin-induced chloracne--reconstructing the cellular and molecular mechanisms of a classic environmental disease. Exp Dermatol 15, 705-730. 
Pohjanvirta, R., Korkalainen, M., McGuire, J., Simanainen, U., Juvonen, R., Tuomisto, J. T., Unkila, M., Viluksela, M., Bergman, J., Poellinger, L., and Tuomisto, J. (2002). Comparison of acute toxicities of indolo[3,2-b] carbazole (ICZ) and 2,3,7,8-tetrachlorodibenzo-p-dioxin (TCDD) in TCDD-sensitive rats. Food Chem Toxicol 40, 1023-1032.

Puga, A., Maier, A., and Medvedovic, M. (2000). The transcriptional signature of dioxin in human hepatoma HepG2 cells. Biochem Pharmacol 60, 1129-1142.

Reed, G. A., Peterson, K. S., Smith, H. J., Gray, J. C., Sullivan, D. K., Mayo, M. S., Crowell, J. A., and Hurwitz, A. (2005). A phase I study of indole-3-carbinol in women: tolerability and effects. Cancer Epidemiol Biomarkers Prev 14, 1953-1960.

Safe, S. (2001). Molecular biology of the Ah receptor and its role in carcinogenesis. Toxicology Letters 120, 1-7.

Safe, S., Qin, C., and McDougal, A. (1999). Development of selective aryl hydrocarbon receptor modulators for treatment of breast cancer. Expert Opin Investig Drugs 8, 1385-1396.

Safe, S., and Wormke, M. (2003). Inhibitory aryl hydrocarbon receptor-estrogen receptor alpha cross-talk and mechanisms of action. Chem Res Toxicol 16, 807-816.

Safe, S. H. (1998). Development validation and problems with the toxic equivalency factor approach for risk assessment of dioxins and related compounds. J Anim Sci 76, 134-141.

Sanderson, J. T., Slobbe, L., Lansbergen, G., Safe, S., and Van den Berg, M. (2001). 2,3,7,8-Tetrachlorodibenzo-pdioxin and diindolylmethanes differentially induce cytochrome P450 1A1, 1 B1 and 19 in H295R human adrenocortical carcinoma cells. Toxicol Sci 61, 40-48.

Sherratt, P. J., McLellan, L. I., and Hayes, J. D. (2003). Positive and negative regulation of prostaglandin E2 biosynthesis in human colorectal carcinoma cells by cancer chemopreventive agents. Biochem Pharmacol 66, 51-61.

Shertzer, H. G., and Sainsbury, M. (1991). Chemoprotective and hepatic enzyme induction properties of indole and indenoindole antioxidants in rats. Food Chem Toxicol 29, 391-400.

Steenland, K., Bertazzi, P., Baccarelli, A., and Kogevinas, M. (2004). Dioxin revisited: developments since the 1997 IARC classification of dioxin as a human carcinogen. Environ Health Perspect 112, 1265-1268.

Steinmetz, K. A., and Potter, J. D. (1996). Vegetables, Fruit, and Cancer Prevention: A Review. Journal of the American Dietetic Association 96, 1027-1039.

Sterling, J. B., and Hanke, C. W. (2005). Dioxin toxicity and chloracne in the Ukraine. J Drugs Dermatol 4, 148150.

Stresser, D. M., Williams, D. E., Griffin, D. A., and Bailey, G. S. (1995). Mechanisms of tumor modulation by indole-3-carbinol. Disposition and excretion in male Fischer 344 rats. Drug Metab Dispos 23, 965-975.

Tuomisto, J. (2005). Does mechanistic understanding help in risk assessment-the example of dioxins. Toxicol Appl Pharmacol 207, 2-10.

van Gils, C. H., Peeters, P. H., Bueno-de-Mesquita, H. B., Boshuizen, H. C., Lahmann, P. H., Clavel-Chapelon, F., Thiebaut, A., Kesse, E., Sieri, S., Palli, D., Tumino, R., Panico, S., Vineis, P., Gonzalez, C. A., Ardanaz, E., Sanchez, M. J., Amiano, P., Navarro, C., Quiros, J. R., Key, T. J., Allen, N., Khaw, K. T., Bingham, S. A., Psaltopoulou, T., Koliva, M., Trichopoulou, A., Nagel, G., Linseisen, J., Boeing, H., Berglund, G., Wirfalt, E., Hallmans, G., Lenner, P., Overvad, K., Tjonneland, A., Olsen, A., Lund, E., Engeset, D., Alsaker, E., Norat, T., Kaaks, R., Slimani, N., and Riboli, E. (2005). Consumption of vegetables and fruits and risk of breast cancer. Jama 293, 183-193.

Verhoeven, D. T., Goldbohm, R. A., van Poppel, G., Verhagen, H., and van den Brandt, P. A. (1996). Epidemiological studies on brassica vegetables and cancer risk. Cancer Epidemiol Biomarkers Prev 5, 733-748.

Verschoyle, R. D., Steward, W. P., and Gescher, A. J. (2007). Putative cancer chemopreventive agents of dietary origin: how safe are they? Nutr Cancer 59, 152-162.

Warner, M., Eskenazi, B., Patterson, D. G., Clark, G., Turner, W. E., Bonsignore, L., Mocarelli, P., and Gerthoux, P. M. (2005). Dioxin-Like TEQ of women from the Seveso, Italy area by ID-HRGC/HRMS and CALUX. J Expo Anal Environ Epidemiol 15, 310-318.

Wattenberg, L. W. (1971). Studies of polycyclic hydrocarbon hydroxylases of the intestine possibly related to cancer. Effect of diet on benzpyrene hydroxylase activity. Cancer 28, 99-102.

WCRF/AICR (2007). Food, Nutrition, Physical Activity, and the Prevention of Cancer: a Global Perspective. AICR, Washington DC.

Wilker, C., Johnson, L., and Safe, S. (1996). Effects of developmental exposure to indole-3-carbinol or 2,3,7,8-tetrachlorodibenzo-p-dioxin on reproductive potential of male rat offspring. Toxicol Appl Pharmacol 141, 68-75. 
Windal, I., Denison, M. S., Birnbaum, L. S., Van Wouwe, N., Baeyens, W., and Goeyens, L. (2005). Chemically activated luciferase gene expression (CALUX) cell bioassay analysis for the estimation of dioxin-like activity: critical parameters of the CALUX procedure that impact assay results. Environ Sci Technol 39, 7357-7364.

Zeligs, M. A. (2002). DIM and I3C: The real facts on safety. www.dimfaq.com/site/I3C-safety.htm.

Zhang, S., Qin, C., and Safe, S. H. (2003). Flavonoids as aryl hydrocarbon receptor agonists/antagonists: effects of structure and cell context. Environ Health Perspect 111, 1877-1882. 
Een samenvatting voor de leek 

Het eten van groente en fruit wordt als zeer gezond gezien en een aantal epidemiologische studies lijken hier ook op te wijzen. Hoewel de chemische samenstelling van deze voedingsmiddelen buitengewoon complex is, heeft men veel onderzoek verricht naar afzonderlijke stoffen in groenten en fruit die verantwoordelijk zouden kunnen zijn voor de effecten op de gezondheid. Een voorbeeld van zo'n stof is indol-3-carbinol (I3C), afkomstig uit spruitjes en andere koolsoorten, waarvan uit dierstudies bekend is dat het bepaalde vormen van kanker kan tegengaan. Het gevolg is dat deze stof in pillen of capsules met een zeer hoge dosis, tot honderden malen de hoeveelheid in een bord vol spruitjes, commercieel verkrijgbaar is. Omdat het om een "natuurlijke" stof gaat, zou een uitputtend toxicologisch onderzoek zoals bij medicijnen niet nodig zijn. De vraag is echter of dit wel zo verstandig is, aangezien deze stof en een aantal in het lichaam gevormde omzettingsproducten (metabolieten) binden aan de zg. Ah-receptor (aryl hydrocarbon receptor), een eiwit dat voorkomt in bijna alle cellen van dieren en dus ook mensen. Deze Ah-receptor wordt ook wel de dioxine receptor genoemd, omdat het beruchte milieuverontreinigende dioxine, bekend van vele krantenberichten over milieuproblemen, via binding aan en activering van dit eiwit zijn giftige effecten veroorzaakt. Hierdoor rijst de vraag of die natuurlijke Ah-receptor activatoren ook giftige effecten kunnen veroorzaken. Intussen worden er steeds meer natuurlijke stoffen ontdekt die aan de Ah-receptor binden en deze kunnen activeren, voor het gemak aangeduid met NAhRAs (Natuurlijke Ah-receptor agonisten), waaronder bergamottin in grapefruit.

Dit proefschrift probeert meer licht te werpen op de overeenkomsten en verschillen tussen natuurlijke en milieugevaarlijke Ah-receptor agonisten. Dit is onder meer gedaan op het onderzoeksgebied van genexpressie en gentoxiciteit in cellen, dus op DNA niveau.

In hoofdstuk 2 wordt het effect beschreven op genexpressie na blootstelling van gekweekte menselijke darmcellen (Caco-2) aan dioxine (TCDD), benzo[a]pyreen (BaP, een kankerverwekkende stof in o.a. sigarettenrook en aangebrand voedsel) en diverse NAhRAs (ICZ, een metaboliet van I3C, en extracten van grapefruitsap en citruspulp). Middels de microarray techniek, waarbij de relatieve hoeveelheid in de cellen gevormd mRNA wordt gemeten (het product van de zogeheten expressie van de genen, de dragers van de erfelijke eigenschappen gecodeerd door het DNA), werd de expressie van duizenden verschillende genen bepaald. Verwacht werd dat de natuurlijke stoffen met effecten op de AhR een (fors) aantal andere genen hoger of lager tot expressie zouden laten komen dan de nietnatuurlijke. Echter, van de duizenden genen werden er maar ongeveer twintig duidelijk beïnvloed en wel op ongeveer gelijke wijze bij zowel de natuurlijke als de niet-natuurlijke Ah-receptor agonisten. Van een aantal genen was al in de literatuur bekend dat ze beïnvloed werden door dioxine, en de meeste van deze genen kunnen betrokken zijn bij het ontstaan van kanker. Op genexpressie-niveau in darmcellen bleek er dus geen duidelijk onderscheid te zijn tussen dioxine, BaP en NAhRAs. Van één van de tot expressie gekomen genen is de werkzaamheid van het bijbehorende eiwit bepaald (het enzym CYP1A1). De activiteit van dit enzym blijkt door TCDD, BaP, ICZ en het citruspulp extract verhoogd te worden maar door het grapefruitsap extract sterk geremd te kunnen worden. Dit duidt 
op een verschil van sommige NAhRAs ten opzichte van dioxine in effecten op de werking van de eiwitten die gevormd worden (dit zijn op hun beurt de producten van het eerder genoemde mRNA dat wordt afgelezen van de genen.).

In hoofdstuk 3 is het onderzoek beschreven naar de mate van voorkomen van NAhRAs in belangrijke voedingsmiddelen waaruit het gemiddelde Nederlandse menu bestaat. Dit is uitgevoerd met behulp van de CALUX-methode. Deze methode behelst het blootstellen van genetisch gemodificeerde rattencellen aan extracten van voedingsmiddelen en aan dioxine als standaardstof. De cellen zijn zo bewerkt dat bioluminecentie optreedt als NAhRAs of dioxines de cel binnenkomen en binden aan de Ah-receptor. Dit signaal wordt met een luminometer gemeten en hoe hoger het signaal, des te meer NAhRA of dioxine er aanwezig is. Op deze manier kan worden bepaald hoeveel NAhRAs er in totaal in de voeding zitten ten opzichte van dioxine. Het blijkt dat de hoeveelheid NAhRAs in de Nederlandse voeding vele malen hoger is dan die van dioxine. Deze methode zegt echter nog niets over de eventuele giftigheid van NAhRAs.

Hoofdstuk 4 beschrijft het onderzoek naar de genexpressie in menselijke bloedcellen na het consumeren van spruitjes en grapefruitsap, die beide relatief veel NAhRAs bevatten. Eerst is gekeken naar de genexpressie in uit mensenbloed geïsoleerde en gekweekte cellen (lymfocyten) nadat deze cellen tijdens het kweken waren blootgesteld aan dioxine en NAhRAs. Ditmaal werd een microarray-techniek gebruikt waarbij de expressie van tienduizenden genen kan worden bepaald. Hierbij bleek dat de expressie in deze cellen veel minder gevoelig is voor Ah-receptor agonisten dan in de darmcellen. Ook bleek dat het expressieprofiel van het grapefruitsap extract verschilde van dat van dioxine, terwijl ICZ (uit spruitjes) wel bijna hetzelfde profiel vertoonde. Consumptie van grote hoeveelheden spruitjes en grapefruitsap deed de expressie van een aantal kenmerkende genen voor Ah-receptor activiteit in bloedcellen niet veranderen. Wel was een zeer kleine verhoging van het CALUX-signaal in bloed meetbaar na de consumptie van spruitjes. Het lijkt er dus op dat het consumeren van grote hoeveelheden NAhRA bevattende groenten of fruitdrank de Ah-receptor niet veel extra activeert.

In hoofdstuk 5 wordt een techniek besproken die wat gevoeliger dan de CALUX zou kunnen zijn. Met behulp van een vergelijkbare reportergen methode, de CAFLUX, werden opnieuw de bloedmonsters doorgemeten die verzameld waren na de interventies met spruitjes en grapefruitsap. Hiermee werd bevestigd dat het gehalte aan via de Ah-receptor actieve stoffen in bloed na het eten van spruitjes iets hoger is dan er voor, en dat dit niet bij het drinken van grapefruitsap het geval is.

Ten slotte is in hoofdstuk 6 beschreven welke invloed dioxine en NAhRAs kunnen hebben op de DNA-schade die veroorzaakt kan worden door BaP. De genotoxische stof $\mathrm{BaP}$ is alomtegenwoordig in o.a. sigarettenrook, uitlaatgassen en aangebrand vlees en kan kanker veroorzaken door aan DNA te binden (DNA adducten) en de normale genexpressie daarmee te ontregelen. De effecten van 
dioxine en NAhRAs op BaP-DNA adducten in gekweekte menselijke darmcellen blijken in hoge mate afhankelijk te zijn van de concentraties $\mathrm{BaP}$ in die cellen. Bij een lage concentratie $\mathrm{BaP}$ in de cellen hebben zowel dioxine als de NAhRA ICZ een remmende invloed op de adductvorming (gunstig), terwijl bij een hoge concentratie $\mathrm{BaP}$ er geen effect is. Bij de blootstelling van darmcellen aan $\mathrm{BaP}$ en het NAhRA bevattende grapefruitsapextract treden er heel andere effecten op. Bij een lage concentratie $\mathrm{BaP}$ verhoogt het grapefruitsap de adductvorming (ongunstig), terwijl bij een hoge $\mathrm{BaP}$ concentratie de adductvorming juist sterk wordt verminderd (gunstig). Ook zijn de expressies van een aantal genen bepaald die met dit adductvormings proces te maken kunnen hebben, maar hiermee werd geen correlatie gevonden.

\section{Conclusie}

In voeding zijn grote hoeveelheden via de Ah-receptor actieve stoffen aanwezig. Op genexpressieniveau kunnen deze grote gelijkenis vertonen met het giftige dioxine. Bij het eten van relatief grote hoeveelheden NAhRA bevattende voeding is een verhoogde Ah-receptor activiteit in bloed zeer moeilijk waar te nemen. Het effect lijkt dus gering en men hoeft kennelijk niet bang te zijn voor dioxineachtige vergiftigingsverschijnselen. Tevens bevat voeding ook stoffen die door Ah-receptoractivering gevormde eiwitten kunnen remmen. Of de zeer hoge dosis aan zuivere NAhRAs in voedingssupplementen wel dioxineachtige effecten teweeg kan brengen moet nog nader worden onderzocht. Ondertussen blijkt uit de literatuur dat dioxine zelf voor mensen niet zo extreem giftig lijkt te zijn als decennia terug werd verondersteld en in bepaalde modellen, zoals bij de bovengenoemde adductvormingstest, zelfs gezondheidsbevorderende effecten lijkt te kunnen veroorzaken. Op basis van bevindingen beschreven in dit proefschrift en in combinatie met een groeiende hoeveelheid wetenschappelijke literatuur, kan worden vastgesteld dat inname van groente en fruit niet onder alle omstandigheden resulteert in duidelijk gezondheidsbevorderende effecten. 



\section{Dankwoord}



Eigenlijk begon het allemaal in Wageningen aan de Tuinlaan 5 op het kantoor van professor Jan Koeman, naar wie dus mijn eerste dank toe gaat. Op mijn vraag naar mogelijke onderzoeksprojecten voor een afstudeeropdracht stelde hij als één der onderwerpen de Ah-receptor voor. Aha! Een receptor die gedacht werd een rol te spelen in de giftigheid van dioxine en die ook geactiveerd kon worden door indol-3-carbinol, een natuurlijke stof uit gezonde groente: zeer interessant en lekker ambivalent! En een geslaagde scriptie volgde (met dank aan Ilonka Meerts, Bram Brouwer, Raymond Niesink en Evert Middelbeek), die enkele jaartjes later op bescheiden wijze mede een basis vormde voor onderhavig AIO-project van het Centre of Human Nutrigenomics, met een mooie samenwerking tussen Wageningen en Maastricht.

Een buitengewoon indrukwekkende en leerzame AIO-tijd volgde, waarin ik vele mensen heel veel dank verschuldigd ben. Heel mooi was hierbij dat ik als "oudere jongere" mij toch volledig opgenomen voelde tussen de “jeugdige” AIO’s. Nooit te oud om te leren!

Het NAhRA-team bestaande uit promotor Frederik-Jan van Schooten, co-promotores Jac Aarts en Theo de Kok, en begeleiders Ron Hoogenboom en Ad Peijnenburg wil ik ten zeerste bedanken voor de enthousiaste samenwerking (met veel heen\&weer gevlieg tussen Maastricht en Wageningen) en het vertrouwen in mijn gepuzzel.

Beste Frederik-Jan, hartelijk dank voor deze grote wetenschappelijke kans, jouw geloof in mij en jouw altijd opgewekte en stimulerende sturing aan dit lastige project. Beste Ron, hartelijk dank voor jouw diepgaande discussies en goede en vruchtbare ideeën. Theo, rots in de branding, ondanks ernstige verwondingen aan het been (vliegen moet je toch aan vogels overlaten); jouw buitengewoon positieve benadering van onmogelijke problemen en jouw grandioze gevoel voor humor, deden mij altijd weer vol goede moed verder zwoegen, duizendmaal dank! Beste Jac, ook al zo gewond aan een been (werd dit een NAhRA-epidemie?), ook jij ontzettend bedankt voor de diepgaande discussies en grote inzet, met soms nachtelijke responsen op mijn lastige vragen. Beste Ad, hartelijk dank voor jouw fijne begeleiding in die opmerkelijke microarray wereld.

Daarmee begon het dan ook: microarrays draaien op het Rikilt. En hier was ik meteen in goed gezelschap van héél véél mensen die ik wil bedanken: niet alleen de fijne collega’s (met de meeste koffie momenten in mijn lange loopbaan) Anja (bedankt voor het gezellig inwerken in deze prachtige techniek), toffe kamergenoten Gerrit en Toine, Hakan (dank voor jouw enorme hulpvaardigheid), Liza (dank voor het vele CALUX werk), gezellige Astrid en Jenneke, Karin, Richard, Tafadzwa, Jeroen, Sandra en Marjoke, maar ook de mede-labbewoners zoals Marleen, Esther, Linette, Wendy, Vincent (succes op Harvard!), Evelien, Guus, Armand, Dijk, Wilko, enz, enz... (altijd helpende handen, en een vrolijk radiootje op de achtergrond). Heel veel dank ook aan mijn eerste studente Elise (allemachtig, wat heb jij inmiddels veel van de wereld gezien!), en aan de geheimzinnige en uiterst daadkrachtige Japanse studente Kyoko (Where áre you? Thanks for your wonderful job and your delicious high quality Sake!). Also students Peng Peng and Elsa: thanks for the cooperation! Toen was het PCRren op m'n "oude vakgroep Tox" aan de Tuinlaan waar gelukkig nog een deel van de behulpzame oud-collega's van het afstuderen werkten: Bert (die ook al zo fijn had meegeholpen 
aan het I3C-labwerk!), Laura (dank voor het vele CAFLUX-werk!), Hans, Tinka (dank voor het vruchtbare gesprek met Mike Denison; also thanks to him!), Gerrit, Irene en Gré en de nieuwere lichting Marelle, Walter, Ans, Anne-Marie, Annemarie, Suzanne, Maaike, Wiratno, Elton, Jelmer, Marjan, Hester, Yee en Ivonne, en natuurlijk mijn fantastische kamergenoten Merijn en Marcel: bedankt voor een toffe tijd! En vrijwilligster Ans.; hartelijk dank voor jouw enorme inzet en wat gaaf dat je nu ook aan het promoveren bent, succes!

Ondertussen maakten de POT-cursussen ook een belangrijk deel uit van het AIO-gebeuren en waar ik met name de "Duitse groep" met hoog internationaal gehalte wilde bedanken voor het gezellig discussiëren en stappen in Wageningen, Leiden en Utrecht. Nadine (thanks also for the great days in Düsseldorf!), Juan, Yuri (really nice talking in Russian cultural depth!), Gudrun, Seema Sing, Hui Li, Min Fang, Jan, Maria and Ana: those wonderful days and nights are unforgettable, thanks! Ook Bas Blaauwboer en Letty Dijker-Lefers: bedankt voor jullie goede organisatie!

Van de CHN-groep bedank ik Ping (Thanks for your kindness and I wish you so much happiness with Kaimei!), Vincent vB (leuk dat je nu als GRATter op 't RIVM zit), Geert en Gabriëlle voor de gezellige en interessante discussies.

Ook NuGO vormde een belangrijk element in de beproeving en hier gaat mijn dank uit naar Ben van Ommics $\odot$, Fré Pepping, Ingeborg van Leeuwen-Bol, Jaap Keijer, Edwin Mariman en natuurlijk naar die zéér vele enthousiaste collega's uit vele landen. One very special colleague of these has to be mentioned: dear Birgit from Sweden; Tack så mycket for the wonderful times in Sverige and Firenze! I wish you much happiness with Ella and that you will succeed in finishing your PhD-project soon! Uiteindelijk mocht ik in die prachtige oude stad Maastricht het werk afronden. GRATters Jonathan en Joep (fijne kamergenoten!), Danitsja, Lonneke, Hans, Joyce, Denny, Joost, Yvonne, Sabine, Nejla, Nicole, Anne (dank ook voor jouw medewerking in de slotfase!), Karen, Yvonne vH, Kirsten, Kevin, Marcello en Lou en Edwin en Ralph (dank voor jullie techno-hulp!), Daniëlle, Karen B, Lucien, Sahar en Simone (bedankt voor jullie gezellige lunches), Geja, Antje, Ad, Jacco, Jan, Roger, Joost vD, Jos, René, Rob, Anneloes en natuurlijk die goede en altijd hulpvaardige Marie-Claire: hartelijk dank voor het meewerken in een fantastische vakgroep! De studenten Jennifer, Stefan en Jody: bedankt voor jullie grote inzet!

Ongetwijfeld ben ik nu nog een heleboel mensen vergeten: ook zij zijn hierbij bedankt $\odot$. Ook mijn familie, vrienden en fijne huidige RIVM-collega's (nu toch echt te veel om allemaal op te noemen!) wil ik hierbij bedanken voor hun steun en aandacht. Ton, al bijna een halve eeuw mijn goede vriend: bedankt voor jouw bijdrage; neef Robert, dank voor jouw gezellig optimisme; Paul, ons dialectisch gefilosofeer geeft mij vleugels; lieve Tiny, bedankt voor jouw aanstekelijk enthousiasme en alle succes met jouw promotie! Zoals Darwin eens zei: "A man's friendships are one of the best measures of his worth".

Tot slot wil ik mijn ouders bedanken voor mijn opvoeding en hun geloof in mij. Lieve pa, wat verdrietig dat je deze mooie mijlpaal niet meer hebt kunnen meemaken; je zou er ongetwijfeld mee in je nopjes zijn geweest! Lieve ma, wat fijn dat je zo trots op me kan zijn! Broer en schoonzus Dick en Jolanda, heerlijk dat jullie er weer bij zijn, bedankt! 
And last but surely not least: mijn paranimfen en beschermengelen Connie en Merijn: ontzettend bedankt voor jullie hulp en het aan mijn zijde willen staan tijdens dit grootse gebeuren! Zulke enthousiaste en optimistische mensen als jullie, waarvoor het leven toch niet altijd even gemakkelijk is, zijn een enorme weelde en een onmisbare steun in deze wonderbaarlijke maar harde wereld...

En Mestreech? Verruild voor Utreg, maar blijft in m'n hart! Een "ode" is op z'n plaats: (Met dank aan Lou en vrij naar Heinrich Heine)

In de straote vaan Mestreech aon de Maos

Weurt Vastelaovend gevierd

Dao flikkere de 6ougies, dao spä̈lt de meziek,

Dao danse de lui, Kleurriek verseerd

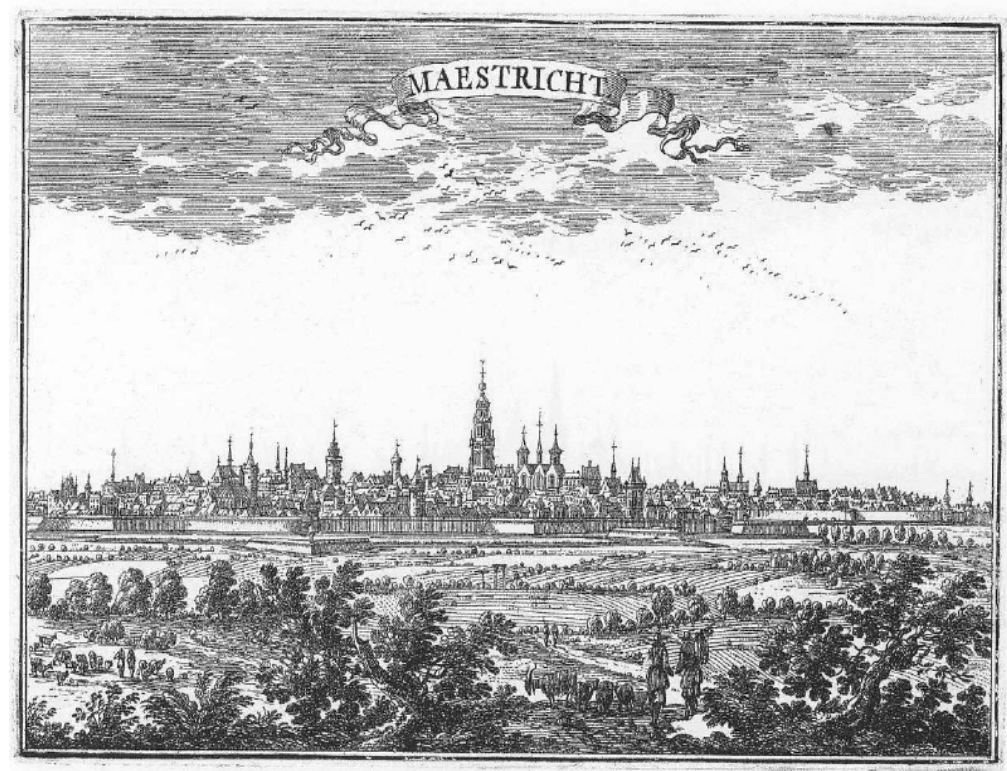



Curriculum vitae 

Pim de Waard was born on the $8^{\text {th }}$ of June 1959 in Rhoon, Zuid-Holland. In 1975 he finished Secondary School MAVO-4 at Meyenhage, Rotterdam, after which he started the Higher Professional Education in Analytical Chemistry at Van’t Hoff Institute, Rotterdam. After finishing in 1979 he worked as a Chemical Engineer at Hercules Inc, Zwijndrecht until 1989. From then till 2000 he worked as a Pharmaceutical Engineer at the Hospital Pharmacy of Gelderse Vallei, Bennekom. Besides this appointment he performed the Master study Food and Toxicology at the Open University, getting his Drs. degree (MSc.) in 1999. In 2000 he became a Researcher Biotechnological Pharmaceuticals at RIVM (National Institute of Public Health and the Environment), Bilthoven. In 2003 he started his PhD project at three locations: RIKILT Institute of Food Safety (Wageningen), the Division of Toxicology, Wageningen University, and the Department of Health Risk Analysis and Toxicology, Maastricht University. Besides, he participated in a number of Postgraduate Education in Toxicology courses, including Laboratory Animal Science (art.9), in order to obtain the certification as Toxicologist at graduation. In 2007 he returned to the RIVM as a Preclinical Assessor at the Centre of Biological Medicines and Medical Technology. 

List of publications 



\section{Peer ReViewed papers}

Pim de Waard, Jac Aarts, Ad Peijnenburg, Hakan Baykus, Elise Talsma, Ans Punt, Theo de Kok, Frederik-Jan van Schooten, Ron Hoogenboom:

Gene expression profiling in Caco-2 human colon cells exposed to TCDD, benzo[a]pyrene, and natural Ah receptor agonists from cruciferous vegetables and citrus fruits.

Toxicology in Vitro 22 (2008) 396-410.

Pim de Waard, Jac Aarts, Ad Peijnenburg, Theo de Kok, Frederik-Jan van Schooten, Ron Hoogenboom:

Ah receptor agonist activity in frequently consumed food items.

Food Addit Contam 25 (2008) 779-787.

Pim de Waard, Theo de Kok, Lou Maas, Ad Peijnenburg, Ron Hoogenboom, Jac Aarts, Frederik-Jan van Schooten:

Influence of TCDD and natural $\mathrm{Ah}$ receptor agonists on benzo[a]pyrene-DNA adduct formation in the Caco-2 human colon cell line.

Mutagenesis 23 (2008) 67-73.

Pim de Waard, Ad Peijnenburg, Hakan Baykus, Jac Aarts, Ron Hoogenboom, Frederik-Jan van Schooten, Theo de Kok:

A human intervention study with foods containing natural Ah-receptor agonists does not significantly show AhR-mediated effects as measured in blood cells and urine.

Accepted by Chem Biol Int.

Pim de Waard, Laura de Haan, Matthéüs Wassens, Lubbartus van den Dikkenberg, Frederik-Jan van Schooten, Ad Peijnenburg, Theo de Kok, Ron Hoogenboom, Jac Aarts:

Repeated exposure of green-fluorescent protein-based reporter cells (DRE-CAFLUX) improved detection of non-persistent aryl hydrocarbon $(\mathrm{Ah})$ receptor agonists in low concentrations in human blood plasma.

In preparation. 


\begin{abstract}
s
Pim de Waard, Theo de Kok, Lou Maas, Ad Peijnenburg, Ron Hoogenboom, Jac Aarts, FrederikJan van Schooten: Influence of natural ah-receptor agonists on benzo[a]pyrene-dna adduct formation in the caco-2 human colon cell line. Oral presentation at the annual meeting of ECNIS (Environmental Cancer Risk, Nutrition and Individual Susceptibility), 2007, Maastricht, The Netherlands.
\end{abstract}

Pim de Waard, Ad Peijnenburg, Ron Hoogenboom, Jac Aarts, Theo de Kok, Frederik-Jan van Schooten: Gene expression profiling in human lymphocytes exposed to natural Ah-receptor agonists. Oral presentation at the annual meeting of NTC (Netherlands Toxicogenomics Centre), Work in Progress, LUMC, 2006, Leiden, The Netherlands.

Pim de Waard, Ron Hoogenboom, Ad Peijnenburg, Jac Aarts, Theo de Kok, Frederik-Jan van Schooten: Natural AhR agonists in the human diet: gene expression profiling in human blood cells. Oral presentation at the NVT annual meeting, 2006, Wageningen, The Netherlands.

Pim de Waard, Ad Peijnenburg, Ron Hoogenboom, Jac Aarts, Frederik-Jan van Schooten, Theo de Kok: Profiling of gene expression modulation in human lymphocytes is not a sensitive biomarker for exposure to Ah-receptor agonists. Poster presentation at the third NuGO (European Nutrigenomics) Conference, Keble College, 2006, Oxford, Great-Brittan.

Pim de Waard, Ron Hoogenboom, Ad Peijnenburg, Jac Aarts, Theo de Kok, Frederik-Jan van Schooten: Natural AhR agonists in the human diet: beneficial food components or unperceived risk factors? Oral presentation at the NTC symposium Work in progress, Maastricht University, 2005, Maastricht, The Netherlands.

Pim de Waard, Ron Hoogenboom, Ad Peijnenburg, Jac Aarts, Theo de Kok, Frederik-Jan van Schooten: Natural AhR agonists in the human diet: beneficial food components or unperceived risk factors? Oral presentation at the NVT annual meeting, Organon, 2005, Oss, The Netherlands.

Pim de Waard, Ron Hoogenboom, Ad Peijnenburg, Jac Aarts, Theo de Kok, Frederik-Jan van Schooten: Natural AhR agonists in the human diet: Gene expression profiles in the human intestinal cell line Caco-2. Oral presentation at the second NuGO Conference, International Conference Center Il Ciocco in Castel Vecchio Pascoli, 2005, Tuscany, Italy.

Pim de Waard, Ron Hoogenboom, Ad Peijnenburg, Jac Aarts, Theo de Kok, Frederik-Jan van Schooten: Natural Ah Receptor Agonists in the human diet: beneficial food components or unperceived risk factors? Poster presentation at the 6th Düsseldorf Symposium Immunotoxicology, 
Biochemistry and function of the Arylhydrocarbon Receptor and other PAS-bHLH proteins, University of Düsseldorf, 2005, Düsseldorf, Germany.

Pim de Waard, Ron Hoogenboom, Ad Peijnenburg, Jac Aarts, Theo de Kok, Frederik-Jan van Schooten: Natural Ah Receptor Agonists in the human diet: beneficial food components or unperceived risk factors? Poster presentation at the first NuGO Conference, Wageningen International Conference Center, 2004, Wageningen, The Netherlands.

Pim de Waard, Ron Hoogenboom, Ad Peijnenburg, Jac Aarts, Theo de Kok, Elise Talsma, Ans Punt, Frederik-Jan van Schooten: Natural Ah Receptor Agonists in the human diet: beneficial food components or unperceived risk factors? Oral presentation at the 34th annual meeting "Genes and environment, bridging the gap" of EEMS (European Environmental Mutagen Society), Hotel Crown Plaza, 2004, Maastricht, The Netherlands.

Pim de Waard, Ron Hoogenboom, Ad Peijnenburg, Jac Aarts, Theo de Kok, Frederik-Jan van Schooten: Natural Ah Receptor Agonists in the human diet: beneficial food components or unperceived risk factors? Poster presentation at the NVT annual meeting "Back to the future", Koningshof, 2004, Veldhoven, The Netherlands. 